Universidade de São Paulo

Faculdade de Filosofia, Letras e Ciências Humanas

Curso de Pós-Graduação em Sociologia

\title{
DO SUJEITO DE DIREITO AO ESTADO DE EXCEÇÃO: \\ O PERCURSO CONTEMPORÂNEO DO SISTEMA PENITENCIÁRIO BRASILEIRO
}

Dissertação apresentada ao Departamento de Sociologia da Universidade de São Paulo, como requisito parcial para a obtenção do título de Mestre em Sociologia, sob orientação do Prof. Dr. Sérgio Adorno.

ALESSANDRA TEIXEIRA 
Para Sérgio, meu grande amor, meu melhor amigo.

E para Theo, a luz de nossas vidas. 


\section{AgradeCimentos}

Inevitável que todo o trabalho acadêmico se realize mediante a participação de muitas mãos e cabeças que, juntas, motivam, inquietam e acompanham seu autor principal. Este estudo não é diferente, o que me coloca a exigência de registrar meus agradecimentos a todas as pessoas que, com maior ou menor intensidade, estiveram implicadas nesse meu percurso de quase uma década de trabalho com a questão carcerária.

Devo agradecer ao meu orientador, Sérgio Adorno, pela oportunidade conferida e pelas considerações e questionamentos tecidos ao longo do período que foram centrais à definição do meu problema de investigação.

A Vera Telles e a Fernando Salla, presentes em minha banca de qualificação, agradeço para muito além das sugestões e contribuições oferecidas naquele momento, que foram valiosíssimas. A Fernando agradeço pelas diferentes ocasiões em que discutiu comigo o objeto deste trabalho, me apresentando questões da maior relevância ao seu desenvolvimento, além da gentileza em disponibilizar materiais e documentos e compartilhar algo mais precioso ainda, seu profundo conhecimento sobre o universo das prisões. A Vera sou grata pelo carinho com que me acolheu em seus dois cursos da pós-graduação os quais freqüentei, mas, sobretudo, pela generosidade com a qual tende a partilhar suas mais recentes investigações e análises, conjugando seu conhecimento de modo indistinto entre aqueles que o procuram. Com ela pude estender meu olhar sociológico para além das fronteiras do sistema penal.

A Eneida Haddad, quaisquer palavras que eu escreva certamente não corresponderão à medida da minha gratidão à sua amizade e ao irrestrito apoio que me forneceu desde muito antes do meu ingresso no mestrado, bem como não darão conta ainda do profundo respeito que nutro pelo seu trabalho de socióloga. Agradeço também a leitura criteriosa e criativa que fez deste texto, bem como sua disponibilidade em fazê-la, ainda que num momento adverso.

Aos amigos Renato Lima e Jacqueline Sinhoretto, companheiros de pesquisa e de discussões sobre o sistema de justiça criminal, pelo papel decisivo que desempenharam na minha formação sociológica, e ainda pelo incentivo à minha candidatura ao mestrado.

A Maria Emília Guerra Ferreira devo a descoberta de uma atuação na questão carcerária pautada efetivamente na dimensão emancipatória do sujeito de direito na prisão, na qual é possível transformar discursos em verdadeiras práxis. Agradeço a ela o muito que 
aprendi enquanto trabalhamos juntas no hoje extinto Hospital Central do Sistema Penitenciário, e pela amizade e o carinho cultivados desde então.

Aos meus amigos e companheiros de militância do Colibri e do Grupo de Estudos e Trabalho Mulheres Encarceradas, pelas lutas, sonhos e renovadas esperanças em um outro sistema carcerário.

Às minha amigas, e também companheiras de pesquisa na Fundação Seade, Lilian Konishi e Eliana Bordini, pelo interesse e carinho sempre por elas dispensados, bem como pelas contribuições e orientações conferidas, especialmente no que toca à produção e ao tratamento dos dados quantitativos para este estudo.

Contei com uma importante interlocução a respeito de recentes pesquisas e abordagens sobre o sistema penal dos amigos Fernanda Matsuda, Mariana Raupp e Messias Basques. A Fernanda, muito especialmente, devo um agradecimento que vai além: muito presente no último ano da minha pesquisa, tem sido uma amiga por demais dedicada, lendo os originais deste trabalho, ainda quando inconclusos, oferecendo sugestões e me auxiliando nas inevitáveis operações práticas e formais, comumente penosas para mim.

A Andrei Koerner, agradeço, primeiramente, sua atenção e disposição para debater comigo o tema deste trabalho, ainda quando o objeto se encontrava em formação. Sou grata ainda pelo fornecimento de diferentes materiais bibliográficos, em especial dos valiosos estudos de sua autoria ainda não publicados.

Às amigas da pós-graduação Eliane Alves da Silva e Caren Ruotti agradeço o carinho com que me receberam e me acolheram num ambiente e num universo que eram absolutamente novos para mim. A Caren, pelas oportunidades em que dividimos nossas angústias e expectativas, e o consolo desses encontros; sou grata ainda pela ajuda conferida no levantamento de documentos e materiais para a pesquisa. A Eliane, pela pronta disposição em solucionar minhas dúvidas metodológicas, pela atenção e preocupação sempre demonstradas e pelo carinho em me incluir e me deixar a par das discussões e contribuições mais recentes e importantes do Cenedic.

Para o levantamento empírico contei com a ajuda e a contribuição indispensáveis de Gorete Marques e Silmara Lauar. A Gorete, agradeço a prontidão em procurar e me fornecer, sempre com boa vontade, documentos e materiais da Comissão Teotônio Vilela fundamentais para minha pesquisa. A Silmara, sou grata por ter providenciado o desarquivamento das diversas CPIs sobre o sistema carcerário instaladas na Assembléia 
Legislativa, num momento político bastante adverso, em que dificilmente eu teria êxito sem sua ajuda.

Agradeço ainda a todos os meus entrevistados por terem se predisposto a me prestarem seus depoimentos, sobre questões e temas nem sempre confortáveis e não obstante muitas vezes o delicado papel institucional por eles desempenhado.

Agradeço à CAPES pela concessão de bolsa durante grande parte do tempo de realização desta pesquisa.

À minha amiga Érica, pelo companheirismo de todos esses anos, por estar ao meu lado inclusive nos empreendimentos mais arriscados e nos desvios de trajetória que, sem a sua presença, não teriam sido vividos com a mesma confiança.

Ao meu pai, Roberto, pela força de seu caráter e pelo quanto isso conformou em mim uma determinada percepção do mundo. À minha mãe, Silvia, pela confiança e o apoio de outros tempos, que souberam me fortalecer quando foi preciso. À minha irmã Adriana, agradeço por sua amizade e por sua presença mais do que cotidiana, ambas responsáveis por nossa tão cultivada cumplicidade que se torna cada vez mais imprescindível nesta minha jornada.

Por fim, ao meu companheiro, Sérgio Mazina, o mais importante agradecimento. Muito mais do que o incentivo e o apoio necessários para a realização deste trabalho, sua participação referiu-se ao compartilhamento de cada idéia, descoberta e reflexão realizadas acerca de um universo que sempre nos fascinou e disse respeito muito particularmente às nossas atuações. Foram o rigor de sua análise e a inventividade de seu pensamento que me ajudaram a conduzir o olhar, por diversas ocasiões, para além das primeiras impressões que os fenômenos sociais tendem inicialmente a sugerir. É por tudo isso e muito mais que este trabalho é dedicado a ele, e ao pequeno Theo que, ao seu modo, faz com que cada sonho valha realmente a pena. 


\section{SUMÁRIO}

\section{Resumo/Abstract}

\section{Introdução}

Primeira parte: A persistência da prisão

Capítulo I: Uma instituição total em permanente mutação

1. O advento da prisão

2. A sociedade disciplinar, o modo de produção fordista e o estado de bem-estar social: uma dimensão includente

A docilização dos corpos: a conversão do preso indisciplinado no operário útil

O welfare state e seus deslocamentos: da patologia à privação, do tratamento à ressocialização

3. A derrocada do welfare state, a crise das disciplinas e as novas formas de controle: a perda da dimensão includente

Liberdade e controle numa sociedade dual

O apagamento da figura moral do criminoso e a incapacitação como finalidade do encarceramento

Segunda parte: O sistema punitivo no Brasil contemporâneo

Capítulo II: A transição democrática e a reforma penal dos 80: o tardio ingresso do ideal ressocializador

1. O debate sobre as prisões nos 80: o resgate da política

2. A jurisdicionalização na execução da pena: uma disputa pelo estatuto jurídico do preso

3. A CPI do sistema prisional, o novo Código Penal e a primeira Lei de Execuções Penais - LEP

O processo de institucionalização do debate sobre a questão carcerária (1975-1984)

A LEP e sua negação

4. A política de humanização das prisões em São Paulo e seu desfecho: a negação de direitos 
As medidas de humanização da gestão José Carlos Dias e sua oposição (1983-1986)

Capítulo III: O declínio do ideal ressocializador e a política criminal de exceção a partir dos 90

O contexto

1. A legislação criminal de urgência e o encarceramento massivo

A lei dos crimes hediondos e o seqüestro da política

2. O papel do Judiciário na política criminal de exceção

1. A radicalização da violência institucional entre 1987-1994 e sua legitimação

2. O contexto de surgimento do Primeiro Comando da Capital - o PCC

O Centro de Readaptação Penitenciária de Taubaté, o "Piranhão", como espaço preferencial da exceção

Somos fortes onde o inimigo é fraco

3. A gestão de Nagashi Furukawa (1999-2006) e a nova racionalidade penitenciária

Precedentes: a questão criminal no primeiro mandato de Mario Covas (1995-1998)

A exceção generalizada do RDD e a "ressocialização" dos CRs: dois tempos de uma história

A nova LEP de 2003: a soberania administrativa e o novo estatuto jurídico do preso 


\section{RESUMO}

Este trabalho pretende investigar o percurso da política penitenciária brasileira contemporânea, partindo da aposta nas concepções humanizadoras e ressocializadoras do cárcere que a redemocratização tardiamente introduziu no país durante a década de 80 , até seus desdobramentos que levariam a seu completo avesso. Assim, já no início da década de 90, um conjunto de medidas caracterizadas pela contínua supressão de direitos e pela maior punitividade das sanções impostas a acusados e presos acabou por instalar verdadeiros regimes de exceção dentro do sistema penal, nos quais a figura do sujeito de direito tende, gradativamente, a esvaecer. Outrossim, essa discussão está inserida a partir de um quadro teórico mais amplo que problematiza a persistência da prisão na contemporaneidade, não obstante a crise das disciplinas e a ordem de reconfigurações imposta pelas recentes transformações do capitalismo a todo um mundo social ancorado em suas representações. A análise das práticas e orientações adotadas mais recentemente pelo sistema penitenciário brasileiro é feita levando em conta a pertinência ou não dos deslocamentos ontológicos sugeridos pela literatura eleita neste estudo, a respeito das categorias que conferiam inteligibilidade ao crime, ao criminoso e à punição, e que se apresentam como centrais à compreensão da finalidade atribuída à prisão na atualidade.

Palavras-chave: prisão - política penitenciária - direitos humanos - justiça criminal crime - estado de exceção.

\section{Abstract}

This work intends to investigate the trajectory of Brazil's contemporary penitentiary policy, starting from the bid for humanizing and rehabilitative conceptions of prison which redemocratization tardily introduced during the 80 s, including its developments that would lead to its exact opposite. Therefore, already in the beginning of 90s, a set of measures characterized by continuous suppression of rights and greater punitivity of sanctions imposed to defendants and prisoners was able to install true regimes of exception within the penal system, in which the subject conceived tends gradually to vanish. Moreover, this discussion is inserted through a wider theoretical frame which discusses the persistence of prison in contemporaneity, albeit the crisis of disciplines and the sequence of reconfigurations imposed by recent capitalism transformations to a whole social world founded on its representations. The analysis of practices and guidelines lately adopted by Brazilian's penitentiary system is conducted taking into account the pertinence or not of ontological displacements suggested by the literature elected for this study on categories which provided intelligibility to crime, criminal and punishment and that are presented as central to the comprehension of the goals referred to prison nowadays.

Key words: prison - penitentiary policy - human rights - criminal justice - crime state of exception. 


\section{INTRODUÇÃO}

Quando tínhamos todas as respostas, mudaram as perguntas. (frase escrita em um muro, em Quito, autor desconhecido, citada por Eduardo Galeano em As Palavras Andantes, 1994:52).

O presente estudo tem como proposta investigar as configurações e as novas finalidades conformadas pelo poder de punir na contemporaneidade, levando em conta as dinâmicas e as transformações pelas quais a ordem social tem sido submetida, sobretudo a partir da derrocada, nos países de capitalismo avançado, de um modelo de intervenção baseado no regime da social democracia (welfare state). Não obstante tais transformações terem recomposto o próprio significado da punição nessas sociedades, bem como terem provocado a crise de todo um aparato disciplinador e seus respectivos dispositivos aos quais competia a vigilância e o controle social - hoje sobrepostos por outros mecanismos que já não têm mais sua pretensão reformadora -, a prisão segue como principal modalidade punitiva, e vê seu uso ser intensificado a padrões nunca antes registrados.

O problema de investigação delineou-se, assim, tendo como referência a persistência da prisão na atualidade, não obstante as bases e as condições sobre as quais ela teria surgido e se consolidado, a partir da segunda metade do século XVIII - uma ordem social ancorada nas disciplinas e um dado modo de produção simbolizado na grande indústria -, terem sofrido importantes transformações e se encontrarem em acentuado declínio.

Elegi assim o capítulo I como eixo teórico da dissertação, inserindo tal problemática a partir do estabelecimento de uma conversação com alguns autores que se debruçaram sobre os processos implicados na gênese e na assunção da prisão como sanção penal por excelência, com especial ênfase a Otto Rusche e Georg Kirchheimer e a Michel Foucault. A identificação, ainda nos marcos da sociedade disciplinar, de um deslocamento nas finalidades da prisão a partir do advento do estado de bem-estar social foi problematizada essencialmente levando-se em conta o recente estudo de David Garland, cuja publicação original data de $2001^{1}$. E é também partindo desse trabalho que introduzo a

\footnotetext{
${ }^{1}$ Garland, David. The Culture of control: crime and social order in contemporary society. Chicago: The University Chicago Press, 2001. Utilizei-me, para o presente trabalho, da edição espanhola de 2005.
} 
discussão mais atual acerca do declínio dos pressupostos da política criminal que ele denominou welfarismo penal e sua implicação nas novas destinações que a prisão tem conformado a partir da década de 90. Neste momento, é novamente o pensamento de Michel Foucault, a partir da aula de 21 de março de 1979, no curso de 1978-79 do Collège de France (Naissance de la Biopolitique, 2004) e também o do filósofo Giorgio Agamben (na obra Homo Sacer I, 1998) que iluminam a questão sobre a persistência da prisão, tecendo algumas considerações que implicam em novos significados a ela atribuídos e à própria idéia de punição, ao fornecerem elementos para uma análise sobre as redefinições e as novas formulações que se têm atribuído a categorias tanto da política em geral, como mais especificamente as que compõem o campo informador do sistema penal.

A segunda parte do presente trabalho volta-se ao estudo das práticas que compuseram o sistema punitivo brasileiro contemporâneo a partir da redemocratização. O foco de análise está circunscrito à gama de medidas e ações que integram aquilo que se pode denominar como política penitenciária, ainda que se reconheça a precariedade, até pouquíssimo tempo atrás, de sua formulação enquanto uma política pública definida como tal. Nesse aspecto vale ressaltar a reflexão feita por Adorno e Fischer (1987) no sentido de observar o contínuo esforço empreendido ao longo das sucessivas gestões encarregadas da formulação e execução da política penitenciária no Estado em extrair-lhe seu conteúdo propriamente político, “desqualificando-a” a ponto de apresentá-la como uma questão primordialmente técnica.

O marco referencial que se estabeleceu foi justamente o processo de transição democrática no país, período em que se iniciaram os principais debates sobre a reformulação do modelo de intervenção junto à questão criminal, formalizados na CPI do Congresso Nacional sobre o Sistema Penitenciário entre 1975-76, cujas conclusões conduziram às reformas que seriam empreendidas no âmbito penal, consubstanciadas no conteúdo “liberalizante” do novo Código Penal e na promulgação da primeira Lei de Execuções Penais, ambos em 1984. As promessas para a questão carcerária, prenunciadas por tais estatutos e corroboradas ainda pelo teor do texto constitucional promulgado quatro anos depois, estavam circunscritas à idéia essencial de integrar o indivíduo encarcerado numa ordem social que reconhecesse seus direitos e seu acesso à jurisdição, o que alinharia o Brasil aos preceitos de uma política criminal reintegradora, que vigia em vários países da Europa desde a década de 60. 
Essa diferença de temporalidade que marca o ingresso do ideal ressocializador e humanizador da prisão na política criminal brasileira também pode ser creditada como uma das causas de sua efemeridade e da parca eficácia dos dispositivos legais que a inauguraram. Referido modelo de intervenção penal, similar em seus pressupostos à política que Garland (2005) nominou de welfarismo penal, quando finalmente previsto em nosso ordenamento jurídico, já se encontrava em declínio há mais de uma década em países da Europa e mesmo nos EUA que, apesar de não o terem vivenciado plenamente, conheceram uma política menos repressiva até a década de 70.

A brevidade de vigência dessa "política criminal progressista” é retratada no capítulo III a partir da descrição do contexto que levou à adoção da legislação criminal de urgência dos anos 90, que, ao consagrar um conjunto de medidas de exceção permanente em matéria de política criminal e penitenciária, representou um verdadeiro ponto de inflexão em relação ao cenário dos 80. Dessas medidas, a Lei dos Crimes Hediondos, editada em 1990, permanece como emblemática, não apenas por seu conteúdo, mas principalmente pelo processo de sua aprovação que importou numa eloqüente demonstração daquilo que Francisco de Oliveira (2001) chamaria seqüestro da política. Sua aprovação demarcou o momento em que se dá o "reencontro das temporalidades" da política criminal brasileira com os destinos de um contínuo fortalecimento do Estado penal, vivenciado já há alguns anos pelas sociedades citadas.

Do mesmo modo, é também a partir dos anos 90 que as taxas de encarceramento ascenderão de modo cada vez mais eloqüente e gradativo, impondo reorientações importantes no tratamento da questão carcerária e estando na base ainda de fenômenos com os quais o sistema penitenciário brasileiro passará a ter de conviver desde então, como a formação e o fortalecimento das organizações criminosas nos presídios.

Procurou-se, ao discutir a aplicação dessa política criminal supressora de direitos e garantias, cujo resultado de imediato visível é o encarceramento massivo, não perder de vista também a atuação do sistema de justiça, responsável direto pela operacionalização do sistema penal. Como advertiu Eda Góes (1991), tem sido comum aos trabalhos empreendidos nessa área, sobretudo os que voltam sua análise ao sistema carcerário, não atribuírem a devida importância aos atores que compõem a justiça criminal, ou seja, não destacarem a centralidade de seu papel no processo de controle diferencial das ilegalidades e de constituição da delinqüência a que se refere Foucault (1998: 234). Atenta a essa 
consideração, tentei destacar como a construção jurídica do conceito de jurisdicionalidade da execução penal constituiu um ponto de disputa e uma pedra angular à realização das novas percepções prenunciadas em torno da prisão, no âmbito das reformas de 1984, sobretudo aquela que se referia à inscrição da figura do preso como sujeito de direitos. Procurei demonstrar ainda, inclusive a partir de resultados de algumas pesquisas realizadas sobre o tema, como o Judiciário não se incumbiu da missão que lhe foi conferida por tais reformas, mantendo e reforçando uma atuação pautada na negação de direitos e na distribuição desigual da justiça, antes mesmo da legislação de exceção dos anos 90.

No capítulo IV realizo finalmente uma análise da política penitenciária propriamente dita, empreendida no Estado de São Paulo, a partir da derrocada do conjunto de propostas e iniciativas que se difundiram na expressão humanização dos presídios, realizadas no governo Montoro (1983-86) e tratadas no capítulo II.

A escolha por São Paulo se deu por uma série de razões; a primeira delas é pela óbvia representatividade do Estado em relação à experiência do encarceramento no país, tendo em vista que abriga sozinho pouco menos de metade da população prisional brasileira, ostentando uma taxa de encarceramento que é quase o dobro da nacional ${ }^{2}$. Em outro sentido, a história do encarceramento em São Paulo, a partir do período destacado, é bastante emblemática por, num primeiro momento, dar conta de retratar o cenário político em que as propostas de reformulação do sistema penal, durante o período da redemocratização, foram recebidas e assimiladas, bem como pelo papel central que a política penitenciária paulista tem desempenhado, mais recentemente, na reorientação dos rumos impressos à política penitenciária nacional, sendo o exemplo mais evidente sua contribuição à reforma da Lei de Execuções Penais em 2003, que introduziu, no ordenamento nacional, a “criação” disciplinar paulista RDD - Regime Disciplinar Diferenciado.

Na definição do caráter emblemático a partir do qual a política penitenciária paulista pode ser pensada, é possível elencar uma série de episódios, a partir da redemocratização, que marcaram e têm marcado a questão carcerária brasileira desde então: as medidas de humanização na década de 80 , seguidas da rotina de intensificação da violência institucional promovidas pelas gestões subseqüentes (1987-1993), cujo ápice pode ser simbolizado pelo “Massacre do Carandiru” em 1992; o surgimento da organização

\footnotetext{
${ }^{2}$ Os dados encontram-se insertos no capítulo III.
} 
criminosa PCC - Primeiro Comando da Capital - e sua conseqüente demonstração de força e poder de mobilização da massa carcerária e na instauração de uma nova ordem social dentro mesmo da estrutura institucional da prisão. No entanto, é o conjunto de medidas que implica no gerenciamento da massa carcerária, usando a expressão de Adorno e Fisher (1987), que mais interessou aqui reter, na medida em que ele se estabelece não apenas como reação aos fenômenos relacionados ao cárcere, mas pelo fato de corresponder também, em grande medida, às próprias razões de constituição desses fenômenos.

Minha intenção não foi a de promover um levantamento exaustivo, nem ao menos sistemático, das ações empreendidas no âmbito da administração penitenciária paulista nos anos circunscritos por esse trabalho. O objetivo foi antes identificar as principais diretrizes e linhas de orientação adotadas pelas sucessivas gestões, bem como o contexto em que suas práticas estiveram inseridas, valendo-me, para tanto, do registro de fatos e de dados sobre as administrações, bem como da ordem de representações e percepções de determinados atores envolvidos no processo e em determinados eventos-chave que destacaram o período.

É verdade, contudo, que a partir de 1999, mais precisamente o período correspondente à gestão de Nagashi Furukawa na SAP - Secretaria de Administração Penitenciária -, esse levantamento tendeu a apresentar-se de forma mais sistemática, o que pode ser justificado por duas razões. A primeira se refere à própria constatação alcançada por este estudo no sentido de que, somente a partir da gestão Nagashi é que as ações empreendidas na área da administração penitenciária puderam ser articuladas a ponto de constituírem uma política pública. Foi durante tal gestão que a reforma administrativa da SAP seria finalmente efetivada com a extinção da COESPE - Coordenadoria dos Estabelecimentos Penitenciários do Estado - em 2000 -, conferindo-se à questão penitenciária, a partir de então, a autonomia anunciada desde a criação da Secretaria, em 1993. Referida reforma, por ter promovido a centralização de poder em torno do Secretário de Estado, associada certamente a outros fatores peculiares dessa gestão e a um contexto que se apresentou a ela favorável em muitos aspectos, foi fundamental para que se constituísse uma medida de sustentabilidade ao conjunto de ações empreendidas e para que tais ações ostentassem um caráter programático, o que pôde justificar, em parte, seu "êxito" e sua posterior expansão para além dos limites da política penitenciária local.

A outra razão consiste no caráter recente dos acontecimentos, o que por si só, além de impor um desafio redobrado ao pesquisador na sua relação para com o objeto de análise, 
uma vez que esse se apresenta ainda em formação, carrega em si uma outra dificuldade que se deve ao fato desse objeto ter sido ainda pouco explorado. Logo, diante da escassez, e em muitos aspectos da própria inexistência de outros estudos e trabalhos que já houvessem se debruçado sobre essa específica realidade e que pudessem vir a servir como uma fonte complementar, impôs-se um levantamento mais pormenorizado do conjunto de práticas referentes ao período, o que me levou a lançar mão ainda de diferentes instrumentos metodológicos para a coleta de informações.

Neste ponto, impõe-se tecer uma série de considerações sobre a metodologia adotada, com o objetivo de elucidar as fontes consultadas, as opções e os instrumentos eleitos, tendo sempre em vista que tais decisões compuseram, antes de mais nada, o próprio percurso da minha pesquisa. Para além, é certo ainda que resultaram em muito da adversidade enfrentada nesse percurso, sobretudo pela escassez ou mesmo, em alguns momentos, pela completa ausência de documentos e registros disponíveis, muitas vezes em razão de “intencionais” obstáculos colocados ao seu acesso.

Para o período referente à transição democrática, recorri a estudos (não apenas acadêmicos) para retratar o contexto em que as lutas sociais e as forças democráticas emergiam e seu correspondente impacto no campo penal. Outras fontes foram essenciais à recomposição do meu objeto, em especial o material relativo às sessões da CPI para apurar a situação penitenciária do país, instalada no Congresso Nacional entre os anos de 1975-76. Às 18 sessões realizadas pela CPI, convocaram-se diversos especialistas, técnicos, operadores e profissionais liberais, todos eles instados a compartilhar seus saberes sobre a prisão, num esforço arqueológico para dessujeitá-los, na exata acepção foucaultiana (2002). O conteúdo ${ }^{3}$ desses debates consistiu em um material da maior relevância à minha pesquisa, sobretudo por refletir as concepções que se formavam naquele momento acerca da prisão e do preso, revelando ainda o quanto elas compunham, já àquele tempo, um campo de disputa num cenário em transformação.

Com relação ao momento da edição da legislação criminal de exceção dos anos 90, recorri, além dos estudos mencionados, ao material referente à sessão de votação e

\footnotetext{
${ }^{3}$ Diferentemente das Conclusões, que receberiam grande destaque à época, tendo integrado inclusive a exposição de motivos da lei de execução penal e do código penal de 1984, o conteúdo das sessões não despertaria grande atenção dos especialistas, consistindo em um material mais periférico, de caráter instrumental. O inteiro teor desses debates está no relatório final da CPI que foi publicado à época no Diário do Congresso Nacional, num suplemento de 341 páginas, cuja referência encontra-se ao final deste trabalho.
} 
aprovação, na Câmara dos Deputados, do projeto de lei que redundaria na Lei dos Crimes Hediondos, novamente por revelar, também em consonância ao momento político vivenciado pelo país, o mal-estar de uma experiência democrática absolutamente incipiente. Os debates entre os deputados puderam refletir as pressões e intimidações exercidas por aqueles interessados na aprovação dessa Lei, numa clara demonstração de subtração da política (Oliveira, 2001) pela produção de um forjado consenso (Ranciére, 1996) em torno da supressão de direitos e garantias individuais recém-conquistadas. Utilizei-me, ainda, para descrever os impactos dessas legislações e de toda a política criminal conservadora adotada durante a década de 90, de dados e estatísticas oficias sobre o aumento das taxas de encarceramento nas últimas décadas, bem como do último censo penitenciário do Estado de São Paulo, de 2002, para descrever o perfil do preso por incidência criminal. Recorri também a dados de pesquisas promovidas junto ao sistema de justiça (Adorno, 1995; FSeade, 2003; Teixeira e Bordini, 2005) por permitirem uma reflexão acerca do papel desempenhado por tais instituições e seus representantes no fortalecimento do Estado penal, e sobre sua operacionalização seletiva.

Pensar a política penitenciária a partir de 1987 exigiu uma vez mais rever a bibliografia mais qualificada acerca da temática da segurança pública (Pinheiro e Braun, 1986; Adorno, 1996, Teresa Caldeira, 2003 ${ }^{4}$; César Caldeira, 2000; entre outros) a fim de recompor o quadro de intensificação da violência institucional a que se assistiu no país e, sobretudo, em São Paulo, no período subseqüente ao restabelecimento democrático. Utilizei também como fontes os artigos e as notícias veiculadas pela imprensa ${ }^{5}$, em especial dos jornais Folha de S. Paulo e O Estado de S. Paulo, para um período um pouco mais recente datado a partir de 1994, que corresponde ao início do mandato de Mario Covas no governo do Estado e seus respectivos esforços para, ao menos no campo da segurança, reverter a rotina de violência policial e dos abusos cometidos durante as gestões antecedentes.

\footnotetext{
${ }^{4}$ A primeira edição brasileira de Cidade de Muros de Teresa Caldeira, data de 2000, sendo que me remeto no texto à segunda edição, de 2003. A publicação original em inglês pela University California Press data do mesmo ano, 2000.

${ }^{5}$ De 1996 a 2000 utilizei-me de um acervo organizado pela CTV (Comissão Teotônio Vilela) de notícias veiculadas na imprensa paulista sobre a questão carcerária, e que me foi gentilmente disponibilizado. Antes de 1996, recorri muito pontualmente ao que foi noticiado pela imprensa e, quando o fiz, realizei buscas temáticas nos dois veículos citados.
} 
Para proceder ao inventário e à análise dos episódios e das correspondentes ações que marcaram a política penitenciária empreendida a partir da gestão Nagashi (1999-2006), bem como para recompor os contextos em que estiveram inseridas, utilizei métodos variados de coleta de dados. Passei a dar ênfase à pesquisa documental através do levantamento de instrumentos normativos (resoluções, portarias) e de artigos e notícias da imprensa segundo episódios determinados e específicas temáticas abordadas pelos veículos analisados $^{6}$, bem como recorri mais uma vez às CPI's, no caso da Assembléia Legislativa, instauradas para apuração de fatos emblemáticos, como a "responsabilização pelo Massacre do Carandiru”, em 1992 e a “situação do sistema prisional paulista”, em 2001, logo após a megarrebelião promovida pelo PCC. Mais especificamente com relação a essa última, foi novamente o conteúdo dos depoimentos de diversas figuras chamadas a prestálos (familiares de presos, advogados, juízes, diretores de presídios e até presos) que me forneceram os elementos de maior relevância à configuração da realidade que eu pretendia conhecer, bem como à sua análise, do que propriamente as conclusões as quais a CPI houvera chegado.

Um outro método que passei a utilizar neste momento foi a realização de entrevistas com alguns protagonistas da história do encarceramento em São Paulo nas últimas décadas, muitos deles personagens diretamente envolvidos nos fatos que se pretendeu recompor. À exceção da entrevista realizada com o ex-secretário Nagashi, para a qual se elaborou um roteiro diretivo e pode ser gravada, tendo em vista, inclusive, a inevitabilidade de seu caráter institucional, as demais entrevistas não foram estruturadas, nem gravadas. Para justificar tal opção, é preciso antes tecer algumas considerações acerca dos desvios que integraram esse momento da trajetória de investigação.

No curso da elaboração do capítulo IV, quando justamente começava a recompor os fatos e a política penitenciária adotada nos anos 90, explodiram as mais intensas ondas de atentados do PCC a agentes públicos e também a civis, na cidade de São Paulo, em maio de 2006. Assim, se já consistia uma tarefa essencial a recomposição dos elementos e ações que estiveram na origem do surgimento do PCC, até então uma poderosa organização criminosa atuante primordialmente intramuros, após os ataques de 2006 esse exercício de recomposição e análise tornou-se condição sine qua non para que, não apenas se compreendesse a força e a dimensão de seu poder expresso agora extramuros, mas para a

\footnotetext{
${ }^{6}$ Exemplo dessa “seleção” foi a Edição Extra PCC, da Revista Caros Amigos, de maio de 2006.
} 
compreensão da lógica de operacionalização do próprio sistema, que propiciava, em seus vácuos ou por seus desvios, a formação e o fortalecimentos dessas facções.

Foi, assim, quando da recomposição da gênese da PCC, o momento em que me deparei com o campo mais árido de pesquisa. As informações existentes, divulgadas por diversos meios de comunicação, ressaltavam tão-somente o caráter dantesco e simbólico do ato de sua constituição, remetendo-se aos depoimentos de ex-líderes e ex-integrantes e de suas esposas. O conteúdo dessas informações, contudo, pouco ou nada revelava sobre o que realmente me interessava conhecer, ou seja, as condições institucionalmente dispostas ou não para que uma organização como o PCC surgisse dentro de um único estabelecimento e se expandisse por todo o sistema.

Minha busca então prosseguiu na tentativa de identificar a política que orientava a existência desse estabelecimento de origem, o Anexo da Casa de Custódia de Taubaté, o “Piranhão”. Levantei os instrumentos normativos expedidos pela Secretarias responsáveis em cada período, ou seja, as resoluções que regulamentaram sua destinação e seu funcionamento ao longo dos anos e, para além disso, busquei documentos que atestassem de algum modo o teor das denúncias feitas pelos membros do PCC sobre o Anexo, ou seja, a prática de reiteradas torturas, e, enfim, da crueldade do tratamento destinado no local e da indeterminação do tempo de recolhimento.

Não obstante eu própria ter conhecimento, ao longo dos anos em que venho trabalhando com essa temática, a respeito das práticas cruéis promovidas no "Piranhão" e de sua “fama” no sistema, advinda, aliás, de diferentes fontes (ativistas, presos, técnicos e até dirigentes), para minha total surpresa, não encontrei num primeiro momento qualquer documento que ao menos indicasse alguma denúncia formal ou a procedimentos de apuração de tais fatos. Depois de realizar uma busca mais intensa, através ainda de conversas informais com operadores, militantes e agentes, bem como da análise de alguns depoimentos da CPI do sistema prisional de 2001, cheguei a uma única série de procedimentos investigatórios mais concretos, instaurados em razão de uma visita “surpresa” ao Anexo, realizada por membros da Comissão de Direitos Humanos da OAB/SP e pelo parlamentar Elói Pietá do PT, no início dos anos 90, para apurar denúncias feitas por esposas de presos que haviam sido torturados em data recente. Apesar de não ter 
conseguido localizar ${ }^{7}$ os respectivos processos ou sindicâncias que teriam sido instaurados depois da constatação pela OAB e pelo deputado da violência praticada no "Piranhão", colhi informações com membros da Comissão que me confirmaram o teor das denúncias, tendo sido, de todo o modo, o único procedimento sobre o qual constatei efetivamente a existência, nos quase vinte anos de funcionamento do "Piranhão" como Centro de Readaptação Penitenciária.

Utilizei-me também de uma entrevista realizada pela Comissão Teotônio Vilela CTV - em 10/11/1999, com um ex-presidiário que permanecera dois anos no "regime de cela forte" do "Piranhão" e que pôde testemunhar parte dos horrores praticados e vivenciados naquele local. Novamente devo agradecer aos membros da CTV que me disponibilizaram a íntegra de tal entrevista, mesmo antes de ter se procedido à publicação desse material.

A partir das pesquisas sobre o Anexo de Taubaté foi que passei a lançar mão, de modo mais freqüente, da realização de entrevistas com os protagonistas, direta ou indiretamente implicados nos contextos que necessitava recompor, para a extração não apenas de informações concretas e dados, como também das percepções e representações de que eram portadores. Essas entrevistas visaram reconstituir um objeto muitas vezes polêmico e os entrevistados, também não raro, ainda mantinham vínculos com o poder instituído ou com instituições que naturalmente representavam, exigindo assim que os procedimentos adotados fossem os menos constrangedores possíveis. Portanto, optei por não gravar tais entrevistas e realizá-las de modo focalizado, mas não estruturado, o que me garantiu uma maior motivação e disponibilidade por parte dos meus informantes em conceder-me seus testemunhos.

Reafirmo que a intenção deste estudo foi, no exato sentido da epígrafe disposta na introdução, contribuir na construção de um problema de investigação, ou seja, de uma ordem de (novos) questionamentos que têm emergido de um mundo social em transformação, e para o qual antigas respostas não podem mais se adequar, essencialmente por isso, porque se tratam de novas perguntas.

\footnotetext{
7 Como será relatado no capítulo IV, embora tenha contado com o empenho direto de ex-membros da Comissão e de funcionários encarregados pelo setor de arquivo na localização desse procedimento, a última informação prestada foi de que ele teria sido extraviado.
} 
Delineando esse novo problema, ao colocar essencialmente em conversação as principais reflexões acerca dos deslocamentos que as acepções de crime, criminoso e punição têm sofrido na contemporaneidade, pude testar tais reflexões em um referencial empírico que se apresentou como um campo bastante fértil para análise: o sistema penal brasileiro a partir da redemocratização, com especial ênfase às políticas penitenciárias empreendidas no Estado de São Paulo no período. 
Primeira PARTE: A PERSISTÊNCIA DA PRISÃo 


\section{Capítulo I}

\section{UMA INSTITUIÇÃO TOTAL EM PERMANENTE MUTAÇÃO}

SUMÁRIO: 1. O advento da prisão; 2. A sociedade disciplinar, o modo de produção fordista e o estado de bem-estar social: uma dimensão includente; • A docilização dos corpos: a conversão do preso indisciplinado no operário útil; • O welfare state e seus deslocamentos: da patologia à privação, do tratamento à ressocialização; 3. A derrocada do welfare state, a crise das disciplinas e as novas formas de controle: a perda da dimensão includente; • Liberdade e controle numa sociedade dual; • O apagamento da figura moral do criminoso e a incapacitação como finalidade do encarceramento.

A prisão com toda a tecnologia corretiva de que se acompanha deve ser recolocada aí: no ponto em que se faz a torsão do poder codificado de punir em um poder disciplinar de vigiar; no ponto em que os castigos universais das leis vêm aplicar-se seletivamente a certos indivíduos e sempre aos mesmos; no ponto em que a requalificação do sujeito de direito pela pena se torna treinamento útil ao criminoso; no ponto em que o direito se inverte e passa para fora de si mesmo, e em que o contradireito se torna o conteúdo efetivo e institucionalizado das formas jurídicas.

(Michel Foucault, Vigiar e Punir,1997a:184).

Desde que iniciou seu processo de ascensão como principal meio de punição empregado no Ocidente, em meados do século XVIII, a prisão tem consolidado sua posição em meio a inúmeras transformações sociais, econômicas, culturais e políticas vivenciadas ao longo do tempo, reatualizando, para isso, seu programa e suas atribuições. Assim, em permanente mutação desde sua consolidação, a prisão tem readequado suas funções, através, por exemplo, da implementação de diferentes regimes de disciplina e de modelos penitenciários segundo momentos históricos precisos e de acordo com pressupostos sociais, econômicos e políticos enfrentados por cada sociedade que a adotou como principal modalidade punitiva.

Tais readequações, que podem ser definidas também como ajustamentos, nunca estiveram dirigidas aos aspectos mais estruturais de sua existência, ou seja, não alcançaram a dimensão ontológica da prisão. Na contemporaneidade, no entanto, sobretudo a partir da década de 70 do século $\mathrm{XX}$, a prisão passou a sofrer transformações revestidas de maior radicalidade por estarem dirigidas agora aos seus mais importantes fundamentos, ou seja, 
por colocarem também em transformação justamente aquilo que foi determinante em sua gênese e que tem definido sua atuação até aqui, a saber, sua função de principal instrumental disciplinador nas sociedades capitalistas.

As transformações impostas dizem respeito a dinâmicas sociais, e, sobretudo econômicas, que, na contemporaneidade, têm reordenado as relações de classe, modificado as concepções de trabalho, de família, bem como abalado profundamente a existência das instituições em geral, impondo, assim, novos arranjos que não estão mais referenciados no mundo das disciplinas.

De tais transformações tem emergido o principal desafio colocado hoje à persistência da prisão, referente a como harmonizar suas funções às exigências de uma nova ordem social, econômica e política não mais centrada nos dispositivos disciplinares por excelência, mas em refundados mecanismos de controle e dominação. E, para além disso, como reinventar-se a ponto de impedir sua decadência e sua sobreposição por novas formas de segregação, contenção e controle social?

Contrariando aquelas que seriam as expectativas mais óbvias de uma instituição em crise, o que tem se assistido, contudo, especialmente a partir dos últimos vinte anos, é a um contingente cada vez maior de indivíduos encarcerados, num fenômeno que faz reviver o “grande confinamento” a que Foucault faz alusão na Paris do século XVII (1997b). Na versão contemporânea, contudo, a tendência do encarceramento massivo tende a ultrapassar os limites geográficos e políticos de cada nação, para se apresentar como uma manifestação predominante nas sociedades capitalistas ocidentais em geral, erigindo a prisão à condição cada vez mais destacada de instrumental privilegiado para o controle social nessas sociedades.

Nesse sentido, talvez seja possível ponderar que, em grande medida, o desafio já tenha sido vencido por essa invenção social, e a contemporaneidade tenha resolvido o dilema da superação disciplinar pelo encarceramento massivo para fins precípuos de controle e segregação, ausente qualquer dimensão de reaproveitamento humano. Pode ser uma explicação convincente, mas certamente não encerra em si todas as possibilidades e matizes que tal fenômeno apresenta, nem elucida por si o enigma de um modelo de sociedade que dispensa as disciplinas mas recorre insistentemente ao seu exemplar mais excelente como mecanismo de contenção ou de regulação no mercado de oferta $e$ demanda do crime (Foucault, 2004). 
De todo o modo, esse é ainda um campo de investigação em aberto, sendo certo que não obstante importantes estudos tenham sido empreendidos (Garland, 2005; Wacquant, 2000 e 2001; Christie, 1998), trata-se de um cenário em transformação e, embora alguns deslocamentos e rupturas já tenham se definido, ainda há muito por se delinear, não havendo respostas e conclusões definitivas, apenas apontamentos e indicações.

Este capítulo não tem qualquer pretensão de indicar eventuais respostas ao dilema que se levantou acerca da prisão. Antes disso, a intenção é problematizar o tema da persistência ou não da centralidade da pena de prisão no mundo contemporâneo, resgatando, para tanto, as discussões sobre algumas das configurações adquiridas pelo poder de punir ao longo de diferentes processos sociais, sobretudo a partir do capitalismo ainda comercial. A tentativa de recompô-las é adotada aqui como a chave para a compreensão da expressão a qual a prisão tem adquirido na contemporaneidade, recorrendo-se para tanto aos principais estudos que têm tematizado e investigado mais sistematicamente essa realidade. Por fim, é inevitável ainda que a discussão empreendida neste capítulo acabe por conduzir a algumas hipóteses explicativas, elaboradas a partir das conclusões dos estudos mais destacados e no esforço de os conjugar.

\section{O ADVENTO DA PRISÃO}

Georg Rusche e Otto Kirchheimer, em seu emblemático livro Punição e Estrutura Social, publicado originalmente em 1939, foram os que primeiro descreveram a estreita vinculação entre os sistemas de punição e os processos sociais, econômicos e políticos que os circundam.

A proposta desses frankfurtianos foi estudar a lógica dos mecanismos punitivos não a partir de sua relação com o crime, para o qual, segundo eles, não há essencialmente correspondência fática ou teleológica. Entendendo, a punição como um fenômeno independente de sua concepção jurídica e abstrata $^{8}$-, mas adstrito, ao invés, a manifestações concretas em períodos históricos específicos, os autores promoveram uma

\footnotetext{
${ }^{8}$ A abordagem de Rusche e Kirchheimer também se distancia do tratamento sociológico de E. Durkheim com relação ao crime e à punição, tendo em vista a ênfase empregada por este último ao caráter moral de tais fenômenos, centrando sua análise nos conceitos de coesão social, anomia e na existência de solidariedade e integração nas sociedades modernas (Durkheim, 1999).
} 
transformação radical na perspectiva dos estudos na sociologia dos sistemas penais, inspirando diversos trabalhos decorrentes ${ }^{9}$.

O trabalho de Rusche e Kirchheimer foi precursor ainda na identificação do contexto de nascimento e ascensão da pena de prisão com o desenvolvimento do modo de produção capitalista, abrindo caminho para uma série de outras investigações que retomariam esse pressuposto, ainda que adotando perspectivas e instrumentais de análise diversos, como é o caso dos estudos de Michel Foucault sobre o desenvolvimento dos sistemas de produção da verdade jurídica e distribuição de punições nas sociedades ocidentais (2003a) e sobre o nascimento da prisão (1997a).

Desse modo, a configuração de um modelo punitivo baseado no aprisionamento prolongado com finalidades adestradoras e de reforma moral, também por uma perspectiva de análise a partir dos modos de produção vigentes, não teria encontrado condições de realização em regimes e formas de organização social como as que marcaram o mundo feudal. A predominância de uma economia agrícola demandante de força de trabalho constante e, portanto, não-excedente, com ênfase para o caráter tradicional nas relações entre servos e senhores feudais que caracterizaram o período medievo pré-capitalista, propiciaram a prevalência de um meio punitivo centrado no corpo, mas com uma finalidade precípua de infligir-lhe dor e não de extrair-lhe riqueza ou utilidade, como ao que se assistiria posteriormente com a prisão (Foucault, 1997a). Também outras sanções, como as de caráter econômico (prestação de fianças) não encontravam na estrutura social e econômica disposta no regime feudal, condições de prevalência, diante essencialmente da escassa circulação de bens e riquezas próprias além da própria exigüidade de valores corpóreos por parte das classes baixas, a quem geralmente eram distribuídas as punições (Rusche e Kirchheimer, 1999).

Levando-se em conta a questão da organização política nessas sociedades, é de se notar que a ausência de mediações realizadas por mecanismos de um direito de Estado, ou

\footnotetext{
${ }^{9}$ Michel Foucault atribui, logo no início de Vigiar e Punir, a Rusche e Kirchheimer a importância de terem sido eles os primeiros a extrair da gênese dos sistemas punitivos sua "armadura jurídica” para apresentá-los como fenômenos sociais em relação direta com os sistemas de produção vigentes (1997a). D. Melossi e M. Pavarini, em seu trabalho sobre as origens do sistema penitenciário, publicado originalmente em 1977, retomam em grande medida o pensamento dos autores frankfurtianos, colocando em relação direta o advento do modo de produção capitalista e das instituições carcerárias (2006). David Garland, em seus estudos sobre as reações sociais ao delito na modernidade recente, estabelece uma sorte de relações entre as transformações sociais, econômicas e culturais e as políticas criminais na sociedade anglo-saxã e na norte-americana, discutindo, assim, a persistência do pensamento de Rusche e Kirchheimer (1994).
} 
seja, de um poder político e judiciário que distribuísse a justiça por um regime de verdade como aquele que veio a se desenvolver a partir da baixa Idade Média (Foucault, 2003a), também teria sido um óbice para que a idéia de resposta penal caracterizada por uma pena, como na acepção moderna, pudesse vir a se configurar, especialmente uma sanção de prolongada execução como a prisão, predominando espécies como a vingança privada e a transação civil de valores econômicos, essa última entre aqueles que, obviamente, detivessem meios de realizá-la.

O Mercantilismo, por outro lado, ou ainda o modo de acumulação que esse regime prenunciava, teria sido o primeiro a criar as condições para que o confinamento viesse a se configurar como um instrumento de controle social, sobretudo das classes baixas. No século XVII, as práticas de confinamento seriam inauguradas segundo finalidades de vigilância, contenção e de extração da força de trabalho de um contingente humano que se encontrava nas cidades, composto resumidamente de categorias sociais definidas como indesejáveis.

A partir do século XVII, assim, passou-se a assistir a um processo de efetiva perseguição à pobreza e à mendicância (antes propagadas como um valor na Idade Média, sobretudo pela Igreja Católica) e seu encerramento como instrumento para consolidação de padrões morais de valorização do trabalho e da prosperidade. Registra-se, no período, o surgimento dos Asilos e especialmente das Casas de Correção ${ }^{10}$, que se constituirão espaços privilegiados para o internamento indiscriminado de tais categorias sociais: os loucos de qualquer espécie ${ }^{11}$, os mendigos, os vadios, os idosos, as prostitutas e os condenados. Foucault apresenta o fenômeno da "grande internação” como ilustrativo desse

\footnotetext{
${ }^{10}$ A origem mais remota das workhouses é datada em 1555 (Rusche e Kirchheimer, 1999) quando se conferiu tal destinação ao castelo de Bridewell, em Londres, ou seja, a detenção, mediante trabalho forçado e severa disciplina, de vagabundos, ladrões e ociosos, se popularizando a partir de então, tanto as demais workhouses como as houses of correction, pelo nome de bridewells (Melossi, 2006). É, contudo, a partir do século XVII, que ocorrerá o incremento de sua utilização, em especial na Holanda, que apresentava um regime capitalista já bastante desenvolvido naquele período. Na França, registra-se a criação do primeiro Hospital Geral em 1656, em Paris, com estrutura similar a das casas de correção, em combinação de princípios das casas de assistência aos pobres (poorhouse), oficinas de trabalho (workhouse) e instituição penal (Rusche e Kirchheimer, 1999:62-63) (Melossi, 2006).

${ }^{11}$ R. Castel observa, contudo, que a internação dos loucos irá se operar por uma lógica e por mecanismos diversos. Se com relação aos vagabundos, prostitutas e criminosos a transgressão à ordem autorizava o confinamento como resposta social, no caso dos loucos a ausência de responsabilidade ensejaria um mecanismo de controle diferenciado, não apenas pelo dever de assistência que se impunha por parte do Estado, mas pela introdução da lógica da medicalização dos alienados, que, segundo Castel, não se confundirá com a medicalização do criminoso que irá ocorrer no século XIX tendo como fundamento a ordem jurídica e contratual violada (Castel, 1991).
} 
quadro, quando, no período, $1 \%$ da população parisiense chegou a se encontrar confinada em casas correcionais, hospitais e asilos, num esforço “profilático” de manutenção da ordem pelo imperativo do trabalho e da já mencionada perseguição à pobreza (Foucault, 1997b).

Diversas razões podem ter contribuído para o advento desse processo: um número gradativo de camponeses expulsos para as cidades, em razão da expropriação de seus meios de sobrevivência provocada pelo esfacelamento dos laços feudais e a impossibilidade de sua completa absorção por uma nova atividade produtiva ${ }^{12}$; a escassez de mão-de-obra observada no início do período em toda a Europa, em razão de guerras e epidemias e a necessidade de manter a alta produtividade aliada a um baixo custo da mãode-obra. Há que se registrar ainda que o período é marcado pelo início do predomínio da moral ascética na formação da racionalidade capitalista, para a qual a perseguição à mendicância, em contraponto à consagração à riqueza e ao trabalho, passaria a constituir um pilar ideológico para a ascensão daquilo que Weber (1996) atribuiu como o espírito do capitalismo nas sociedades ocidentais.

Referidos meios de confinamento, pela hibridez de sua população e de suas finalidades, nunca chegaram a consistir numa espécie de sanção penal por excelência, concorrendo com outras modalidades de sanção em vigor: os trabalhos forçados nas galés, as deportações de criminosos às colônias e a pena de morte. Contudo, sua existência pôde representar uma espécie de ruptura com os ideários que norteavam a questão social e a questão criminal até a Idade Média, instaurando ainda novas concepções em relação à pobreza a partir de uma outra mecânica de poder que se investiria sobre os corpos, usando a acepção de Foucault (1998a), para o fim agora de extração de riqueza, disponibilizada através da força de trabalho deles subtraída.

A partir de então, os dispositivos disciplinares serão permanentemente acionados a fim de dar conta dessa nova economia política, passando a operar através de um mundo institucionalmente disposto, inaugurado pelas workhouses e casas de correção do século

\footnotetext{
${ }^{12}$ Essa é uma importante explicação a partir da qual, K. Marx, em O Capital (livro III), situa o fenômeno social do empobrecimento, perseguição e criminalização que os ex-servos, expulsos do campo para as cidades no período, teriam sido submetidos. Marx ainda descreve o tratamento que passou a se destinar àqueles que ele chamou "pais da atual classe operária” através de um conjunto de iniciativas descritas por ele como “legislação sanguinária contra a vagabundagem” (Marx apud Melossi, 2006:35).
} 
XVII e generalizado pelos diferentes espaços de confinamento ou instituições totais que os séculos XVIII e XIX irão conhecer, das quais a prisão será o exemplar mais radical.

Não por acaso, a pena de prisão encontrará sua completa realização material quando do advento das sociedades industriais nos séculos XVIII e XIX, especialmente através da disciplinarização dos corpos que esse novo modo de produção impunha como condição de produtividade ${ }^{13}$.

Antes disso, porém, a importância do pensamento iluminista para as configurações modernas que o poder de punir passará a adquirir, notadamente através das teorias liberais dos reformadores do sistema penal do século XVIII, pode ser compreendida tanto por uma perspectiva que enxerga nelas o arcabouço ideológico para a realização das prisões (Rusche e Kirchheimer, 1999), como para aquela que, ao contrário, vê em tais teorias o ponto de inflexão em relação a um momento posterior em que as instituições disciplinares se consolidariam (Foucault, 1998 e 2003a).

Os reformadores do sistema penal, amparando-se nos princípios informadores das Revoluções Liberais do período, propunham um discurso centrado na racionalização na economia das penas. Essa racionalidade visava, obviamente, conter os abusos de uma outra racionalidade no poder de punir, que até então vigorava nessas sociedades ainda prérevolucionárias que Foucault designou como sociedades de soberania (1997a; 2001). Era esse poder do soberano de fazer morrer e deixar viver, agora anacrônico num mundo afetado por uma nova economia política, que precisava ser atacado e derrotado em seus fundamentos mais sólidos, fundamentos esses correspondentes à própria lógica do regime absolutista, contra o qual a burguesia travava seu maior embate pela conquista do poder.

Fazia parte desse projeto político, por conseqüência, a promoção de uma reforma que visasse instituir mecanismos de maior segurança jurídica (para a burguesia, por certo) a partir de postulados defendidos com vistas a essa espécie de racionalização do direito penal, como o da legalidade, do estabelecimento de uma medida de correspondência entre os crimes e as penas, segundo a tipificação de condutas mais ou menos puníveis e a conseqüente proporcionalidade e individualização na sua aplicação.

\footnotetext{
${ }^{13}$ Foucault observa que, muito embora as disciplinas não tenham sido inventadas pelo capitalista do século XIX, foram por ele apropriadas (com devidos ajustes) e instrumentalizadas, de modo a viabilizar o modo de produção capitalista, e no exercício das relações de dominação constituídas a partir do inerente antagonismo entre capital e trabalho (2002).
} 
A partir de um discurso norteado pelo dogma da igualdade formal, a escala de adequação de penas e delitos traduzia objetivos de liberdade religiosa, moral e econômica ${ }^{14}$ e atribuía, em contrapartida, à defesa da propriedade a centralidade do regime de proteção jurídica pela via penal. Nesse sentido, o ataque à severidade dos castigos tendia a introduzir uma nova economia política das penas: no lugar da pena de morte, o pagamento de fianças na proteção dos bens jurídicos, e, na mesma medida, o encarceramento para aqueles que, naturalmente, não tivessem como prestá-la (Rusche e Kirchheimer, 1999). Por tal perspectiva de análise, portanto, os reformadores iluministas construíram o arcabouço ideológico para a consolidação da pena de prisão como modelo punitivo no Ocidente.

Entretanto, pondera Foucault, tal legalidade extremada, proposta pelo pensamento liberal do século XVIII no âmbito do sistema penal, em nada se assemelharia ao que se observou a partir do século XIX com esse sistema. Ao invés da lógica informadora da punição centrada na retribuição do dano e em sua proporcionalidade, o que se assiste para o advento da prisão é justamente ao contrário: a idéia da pena centrada no indivíduo, não por suas ações concretas, mas por aquelas que poderiam ser cometidas - constituindo-se, em torno do sujeito, a idéia de periculosidade e a imposição de um tipo de intervenção que primasse pela correção desse indivíduo, ao nível de suas virtualidades (1997a, 2003a).

A prisão se realizaria no século XIX, portanto, por mecanismos e princípios diversos daqueles que inspiraram a reforma liberal do século antecedente, não guardando maior correlação ainda que de caráter teórico e jurídico com a mesma. As doutrinas que irão informar o direito penal do século XIX se relacionam muito mais às ciências humanas que surgiam nesse momento, em especial à antropologia, à psicologia, à medicina social e à psiquiatria, do que à teoria do direito, destacando-se o pensamento naturalista da Escola Positiva italiana sobre o delinqüente nato e as formas de seu tratamento ${ }^{15}$.

Nos dizeres de Foucault, é nesse momento, em que a criminologia desponta como um saber especializado sobre o crime e o criminoso, que o homo penalis se converterá em homo criminalis, dando-se tal conversão a partir de toda uma antropologia do crime que substitui, certamente, o rigor econômico e mecânico da lei (2004: 255).

\footnotetext{
${ }^{14}$ Rusche e Kirchheimer indicam os procedimentos de descriminalização do crime de usura como um importante exemplo desse movimento (1999).

${ }^{15}$ Expressa especialmente na tríade C. Lombroso, R.Garofalo e E. Ferri, a Escola Positiva apresentava como postulados essenciais as noções de temibilidade e periculosidade; o termo será melhor explorado por Ferri na sua proposta de classificação antropológica de criminosos.
} 
O deslocamento de trajetória do paradigma punitivo idealizado pelo projeto reformador liberal para o modelo panóptico pode ser analisado de diferentes maneiras, sendo certo que em todas elas a chave interpretativa está na urgência de mecanismos que garantissem a consolidação da então nova ordem social burguesa. É nessa perspectiva que é possível compreender a reestruturação da economia das ilegalidades descrita por Foucault (1997a) e o conseqüente alastramento das formas de vigilância às quais o mundo ocidental irá assistir a partir de então.

Fez parte dessa reestruturação (da economia das ilegalidades), assim, a intolerância recém-adquirida pela burguesia com relação aos ilegalismos populares. Ao contrário de um tempo em que o poder político não lhe pertencia, a burguesia passava agora a temer e coibir, além de pequenos esbulhos e contravenções praticados pelas classes baixas, modos de manifestações populares expressos em revoltas e motins, uma vez que portadores potenciais de um sentido subversivo ou revolucionário.

Na base dessa intolerância, transformações importantes nos modos de produção, de acumulação e distribuição da riqueza, que o capitalismo industrial irá introduzir. A riqueza, antes de caráter mais incorpóreo, passava agora a materializar-se sob a forma de mercadorias, máquinas, matérias-primas, tornando-se, por conseqüência, mais acessível ao contato direto daqueles que não seus detentores ${ }^{16}$ (Foucault, 2003a).

Urgia, então, instalar mecanismos que promovessem a estreita vigilância às massas, assegurando tanto o controle e a propriedade dos meios de produção como a manutenção da ordem, pela prevenção, perseguição e punição das tradicionais formas de mobilização social - os motins e as revoltas populares - por representarem uma significativa ameaça à recém-instituída ordem social capitalista, posto que neles era possível identificar expressões de uma costumeiramente adquirida consciência de classe (Thompson, 2002).

Assim, de um lado a necessidade de proteção dos meios de produção e da riqueza, tendo em vista sua materialidade e o processo de fragmentação da propriedade rural na Europa, e de outro a imperiosidade de consolidação da ordem social burguesa por meio de mecanismos que coibissem e melhor impedissem que quaisquer ameaças à mesma se configurassem, teriam sido importantes fatores para generalização de mecanismos de

\footnotetext{
16 Incluiriam-se nessa categoria não apenas aqueles que passariam a vender sua força de trabalho como condição de sobrevivência uma vez destituídos dos meios de produção, ou seja, o proletariado, como também toda uma massa ainda não categorizável pelo norma salarial (Topalov, 1999).
} 
controle e vigilância por todo o tecido social, mecanismos esses que se configuraram como verdadeira condição para a realização política e econômica do estatuto liberal.

O elemento da vigilância passará, a partir de então, a constituir um ponto sobre o qual a burguesia irá mobilizar intensamente suas forças, elegendo a disciplina como o instrumental mais adequado para a realização do ideário de controle contínuo e dominação; o poder de punir, configurado na espécie prisão, apresentar-se-á como a instância mais exemplar do modelo disciplinar, e por isso, paradigmática dessa nova sociedade e desse novo ethos que se constituíam. 


\section{A SOCIEDADE DISCIPLINAR, O MODO DE PRODUÇÃO FORDISTA E O ESTADO DE BEM-ESTAR SOCIAL: UMA DIMENSÃO INCLUDENTE}

\section{A DOCILIZAÇÃO DOS CORPOS: A CONVERSÃO DO PRESO INDISCIPLINADO NO OPERÁRIO ÚTIL}

“Na verdade, na minha mente nada é mais remoto do que pensar que um preso adulto possa transformar-se num cidadão religioso e virtuoso! (...) Ao contrário, na minha modesta opinião, um bom punhado de criminosos poderá converter-se em bons operários, na medida em que, no cárcere, eles aprenderam uma profissão útil e adquiriram o hábito de um trabalho subordinado, constante disciplinado”. (depoimento de Sr. E. Lynds, diretor da Penitenciária de Sin-Sing e ex-diretor de Auburn, EUA, em entrevista concedida a A. Tocqueville e G. Beaumont, $1831^{17}$ ).

O universo sócio-econômico no qual a pena de prisão teria se consolidado no Ocidente é coincidente com o advento do modo de produção capitalista, mais especialmente com o capitalismo industrial. Não por acaso, esse modo de produção elegeu um outro espaço de confinamento, a fábrica, como local privilegiado para a predominância da disciplina como técnica de adestramento e docilização dos corpos para extração de utilidade econômica e produção de saberes. Todo o aparato disciplinador, acionado a partir do século XVIII através dos processos sugeridos por Foucault e acima descritos, encontrará, no início do século XX, seu retrato mais vigoroso naquilo que se denominou como o modo de produção fordista.

O fordismo, bem como o taylorismo, corresponderam aos regimes de produção predominantes na grande indústria durante a primeira metade do século XX. Marcados por um sistema de forte hierarquização nas relações de trabalho, acirrada divisão social do

\footnotetext{
${ }^{17}$ Melossi e Pavarini anexam à parte final de seu estudo passagens do Anual Report of the Inspectors of the Auburn Penitentiary of Legislature de 8 de janeiro de 1833, integrante do texto final do relatório de A. Tocqueville e G. Beaumont a respeito das visitas às penitenciárias norte-americanas realizadas para o governo francês, ao qual Melossi e Pavarini tiveram acesso através de uma tradução para o inglês, On The Penitentiary System in the United States and its Aplication in France, 1833, p. 225-230 (Melossi e Pavarini, 2006).
} 
trabalho a partir de fragmentação e decomposição de funções (fordismo), num controle rigoroso sobre o tempo e o ritmo de trabalho (taylorismo) e pela produção em massa de mercadorias (Antunes, 2002), esses modelos simbolizaram o ideário panóptico burguês no chão da fábrica, aliando produção frenética à supressão da dimensão intelectual do trabalho, garantidos por dispositivos expressos de vigilância e disciplinarização.

A experiência do confinamento institucional, assim, antes restrita a determinadas categorias de pessoas e de grupos sociais como os loucos, mendigos, criminosos, estendiase a partir desse momento a todas as dimensões da vida social, desde as escolas, os hospitais, as fábricas até as prisões. Era o mundo das disciplinas que se consolidava, e as instituições nas quais ele se realizava compunham-se como um elo, numa relação de continuidade na qual o indivíduo percorreria durante toda a sua vida, como observou G. Deleuze (1992); um percurso único, marcado por diversas transferências de locus institucionais.

A partir do século XIX, portanto, a idéia do encarceramento como principal modalidade punitiva pôde se reproduzir e se naturalizar, encontrando aceitação unívoca por todo o tecido social, inclusive entre as camadas sociais que formariam sua principal clientela: as classes populares. Tal tática exitosa foi possível a partir da nova economia das ilegalidades apontada por Foucault, que consistiu, junto a todo o aparato disciplinar que dela adveio, fator de forte determinação na produção da delinqüência e sua invencível separação das outras ilegalidades que seguiriam imunes a qualquer controle, até os dias atuais $^{18}$.

A dissipação das disciplinas por todo o corpo social, a partir de dispositivos adestradores acionados por diferentes formas e em diferentes esferas da vida social ${ }^{19}$, pôde assegurar, no interior das classes populares, a sujeição a essa diferenciação cuidadosamente construída -, e garantir a conformação à violência desse sistema.

\footnotetext{
${ }^{18}$ Pode-se tomar como referência todas as formas de ilegalidades econômicas, administrativas e políticas, que ainda quando criminalizáveis, permanecem imunes ao controle formal, à persecução penal e à punição de qualquer espécie, sobretudo pela prisão. A respeito, os estudos de E. Sutherland nos anos 50 sobre os whitecollar crimes e as reflexões da criminologia crítica em geral.

${ }^{19}$ As táticas moralizadoras impostas às classes populares, em especial no meio urbano, consubstanciaram-se em medidas que, embora diferentes quanto ao método, voltavam-se ao controle das populações, tendo como referencial, via de regra, a medicina social. As políticas higienistas foram marcantes no período, sobretudo na França, alcançando inclusive o âmbito da intimidade das famílias (Donzelot, 2001). No Brasil, os trabalhos de Costa (1979), Chalhoub (1986) e Adorno e Castro (1985) produzem um importante retrato do cenário e dos dispositivos moralizadores acionados no cotidiano das classes populares do Brasil desde o período colonial.
} 
A organização dos sistemas penais, bem como toda a idéia de justiça penal em si, passará, a partir de então, a se constituir tendo como referencial a prisão ou ainda o sistema carcerário, estabelecendo com ele e a partir dele uma insidiosa relação de dependência e de coexistência. Ao emprestar legalidade a esse sistema, a justiça passará a desempenhar um papel decisivo não apenas na formação desse sistema, como no próprio processo de constituição da delinqüência (Foucault, 1997a). A intervenção dessa agora renovada justiça penal dar-se-á tendo em vista a potencialidade das ações dos indivíduos confinados, introduzindo-se a idéia de prognóstico comportamental como medida para atribuição de castigos, privilégios, amparando-se, para tanto, sobretudo no juízo da periculosidade e na subsunção ao saber médico.

Ao longo da história, os sistemas prisionais sofrerão mudanças e ajustes, diferenciando-se pelos dispositivos disciplinares adotados, e pelo modo de imposição de obrigações, benefícios e, em certos momentos, direitos. Também a questão sobre o maior ou menor poder constituído em torno do administrador prisional e sobre sua margem de arbítrio, naquilo de Melossi e Pavarini denominaram de soberania administrativa, irá pautar o campo de disputa pela prevalência dos diferentes modelos de sistemas penitenciários.

O modelo penitenciário filadélfico, considerado o exemplar mais rígido entre os demais, caracterizou-se pelo intermitente isolamento celular imposto ao condenado, tendo início nos EUA ainda no século XVIII, estendendo-se só posteriormente à Europa. O modelo de solitary confinament inaugurou o sistema penitenciário propriamente dito, vindo sobrepor-se assim ao modelo até então prevalecente das workhouses e das casas de correção, cuja heterogeneidade de sua clientela importava na hibridez de suas destinações, dilema que o sistema penitenciário se propôs a superar. Além de representar a tradução mais ideal do sonho burguês do controle e da vigilância, o modelo filadélfico contou com a forte inspiração e o apoio direto da seita protestante quacker, à criação do primeiro estabelecimento do gênero, em 1790, no Estado da Filadélfia/EUA (Rusche e Kirchheimer, 1999). A base de sua ideologia estaria assentada na crença de que o processo de meditação, à custa do intenso isolamento e do silêncio impostos, conduziria, disciplinadamente, os pecadores (no caso, os prisioneiros) ao arrependimento e, enfim, à sua regeneração.

Teria sido, contudo, o fato do trabalho penitenciário em tal modelo de confinamento solitário se apresentar de modo intrinsecamente antieconômico, não obstante 
a redução nos custos de vigilância que o isolamento propiciava, o que teria levado novamente os EUA a adotarem um novo modelo em sua substituição, modelo esse que visaria uma maior extração de produtividade do trabalho penitenciário, de modo a atribuirlhe uma função propriamente econômica (Pavarini, 2006). Por conseguinte, já no início do século XIX, os EUA substituiriam o sistema filadélfico pelo auburniano, caracterizado pelo trabalho diurno em coletivo, porém em silêncio absoluto e com permissão de comunicação apenas vertical, ao passo que nos países da Europa o solitary confinament teria se prolongado até o final do século $\mathrm{XIX}^{20}$.

Rusche e Kirchheimer (1999) elaboram uma explicação para esse descompasso histórico aliando crises e êxitos econômicos enfrentados pelas sociedades à manutenção ou à superação dos seus respectivos modelos penitenciários. Enquanto os EUA experimentavam, já no início do século XIX, vigoroso aumento da atividade econômica, com crescente demanda de mão-de-obra, o que levava ao interesse pela idéia de (re)aproveitamento máximo dos trabalhadores na economia produtiva, bem como de efetiva utilização do trabalho carcerário, a Europa vivia então fenômeno inverso, com graves crises sociais e trabalhistas, tendo o rígido modelo filadélfico lá se prolongado como medida de escoamento de mão-de-obra excedente e não reincorporável.

Enfim, o sistema progressivo inglês ou irlandês, através do qual o condenado cumpriria a pena em fases ou regimes, progredindo aos mesmos segundo o tempo decorrido e, especialmente, por seu comprovado mérito. Tal sistema, que com devidos ajustes se prolonga até os dias atuais em muitos países, incluindo entre eles o Brasil, consolidou-se na Europa no início do século XX, momento de êxito econômico em boa parte do continente. Ele coincidirá, do mesmo modo, com um novo reformismo penal que se instalava na Europa desde o final do século XIX (Rusche e Kirchheimer, 1999) e com o apogeu da escola criminológica positiva, para a qual a pena de prisão encontraria suas finalidades a partir da lógica corretiva e transformadora que o cárcere promoveria, em oposição à orientação retributiva clássica e liberal.

\footnotetext{
${ }^{20}$ Referida posição de “vanguarda” ostentada pelo sistema penitenciário norte-americano e seus propagados bons resultados na disciplina e na reforma moral dos condenados teriam sido inclusive o motivo da viagem empreendida por Alexis Tocqueville aos EUA no início do século XIX, patrocinada pelo Ministério do Interior da França, e que teria, no entanto, levado o autor a estudos e reflexões mais amplos sobre o país que renderam o clássico A Democracia na América, publicado em 1834.
} 
De todo o modo, a partir do século XIX, através de diferentes sistemas e ideologias, a prisão seguiu, não obstante ainda os movimentos de reforma e talvez justamente através deles, como o modelo de punição racional, obscuro e natural no Ocidente. Sua racionalidade, advinda dos processos aos quais sua gênese e sua existência estiveram desde sempre atreladas, resumiu-se, sobretudo a essa nova economia investida sobre os corpos, nos dizeres de Foucault, e no ocultamento de sua expressão. Produto da modernidade e do capitalismo industrial, a prisão consolidou-se através do discurso ressocializador, implicando por isso uma intervenção que ora se distanciava ora se aproximava desse projeto (re)includente.

No decorrer do século XX, vários episódios produziriam impactos em sua estrutura e no seu escopo, ora pelo incremento de seu uso, ora pela readequação de suas "funções sociais” e de seu programa. As graves crises econômicas e sociais do período de 1929 até o pós-guerra, por exemplo, implicaram em oscilações nas tendências dos níveis encarceramento nos países da Europa e nos EUA (Rusche e Kirchheimer, 1999), havendo relativa estabilização no período subseqüente, até a crise do welfare state.

\section{O WELFARE STATE E SEUS DESLOCAMENTOS: DA PATOLOGIA À PRIVAÇÃO, DO TRATAMENTO À RESSOCIALIZAÇÃO}

Foi no período que sucedeu à $2^{\mathrm{a}}$ Guerra Mundial, quando a política do estado de bem-estar social predominou em boa parte da Europa através de modelo da social democracia, baseado na regulação econômica e na extensão da rede de proteção social controle dos mercados, alargamento da seguridade social, geração de empregos, maior distribuição de riquezas - que a política penal apresentou, pela primeira vez na história, uma formulação capaz de alinhar-se ao quadro maior das políticas propriamente sociais, realizando-se como mais um braço do welfare state.

A essa nova configuração das práticas e instituições penais, emergentes de um novo mundo social em construção, David Garland (1994; 2005) conferiu a expressão welfarismo penal. Baseou-se ele, nos dizeres do autor, num complexo de estruturas sociais $e$ experiências culturais (2005:96), em muito geradas pelo welfare state e reproduzidas no interior da dinâmica de repressão e controle ao crime. Sua existência foi umbilicalmente 
implicada à do estado de bem-estar social, valendo-se assim, das mesmas condições que o viabilizaram - crescimento econômico, pleno emprego, entre outros - tendo contado ainda para sua realização com um certo aporte de um mundo disciplinado e ancorado nas instituições que o fortaleciam.

Sob esse modelo foi que se deu uma transformação importante no interior das

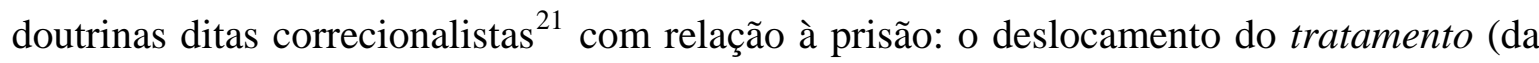
recuperação) para o da ressocialização do criminoso. Essa passagem marca mais do que a instalação de uma nova mediação entre as orientações positivistas e liberais no que se refere à prisão, através de princípios humanitários; ela demarca antes um novo campo de constituição jurídica do preso, sua posição como sujeito de direitos.

Só nessa chave é possível compreender como a prisão e toda a política penal pôde estar inscrita dentro mesmo da estrutura de funcionamento do welfare state, na medida em que ao Estado cumpria a tarefa de (re)inserir socialmente aquele que, por privações ou deficitários mecanismos de socialização, delinqüira, definindo-se essa intervenção como uma política social. Tal é a orientação ainda dos instrumentos normativos internacionais que marcaram o período, representados especialmente pelas Regras Mínimas das Nações Unidas para o Tratamento de Reclusos, de 1955, bem como de uma nova criminologia progressista que despontava, propugnando ambos pela função da punição antes como um dever social em fazer incidir sobre o preso, não para tratá-lo, mas para oferecer-lhe ${ }^{22}$ as condições para o reingresso.

Por certo que tais definições operam com mais significado no plano das ficções jurídicas do que da realização prática e cotidiana das instituições. No entanto, mais uma vez, tais concepções demarcam campos conceituais e definem discursos que não deixam de conformar também práticas, de modo que todo o aparelhamento pelo qual passaram as instituições penais e seus atores, a partir do estado de bem-estar social, esteve alinhado a essa nova percepção quanto à função do encarceramento.

\footnotetext{
${ }^{21} \mathrm{O}$ termo é usado pelo próprio Garland e pela criminologia em geral para se referir indistintamente a todas as concepções que se opõem ao direito penal clássico da pena como retribuição. Garland, contudo, não estabelece no trabalho citado diferenças entre o tratamento e a ressocialização, considerando ambas como práticas que intervêm sobre o indivíduo.

${ }^{22}$ Não por acaso o art. $1^{\circ}$ da Lei de Execução Penal brasileira de 1984, inspirada fortemente por tal orientação, estabelecerá expressamente que a função da pena de prisão é a de proporcionar condições para $a$ harmônica integração social do condenado e do internado, o que pressupõe a aceitação do preso, o elemento da vontade a que juristas se referem como essencial para a "modelação da execução" na consecução da finalidade ressocializadora (Rodrigues, 2001).
} 
O deslocamento do tratamento para a ressocialização não teria sido possível sem que o fundamento epistemológico com relação ao crime não houvesse do mesmo modo sofrido um deslocamento. Durante os anos do welfarismo penal, a criminologia e os estudos sobre o crime que se desenvolveram (E. Sutherland, G.M. Sykes, entre outros) traçaram uma importante relação de causalidade entre o comportamento criminoso e os processos de deficiente socialização e privação constitutivos de suas carreiras criminosas $^{23}$. Essa orientação veio substituir a explicação patológica para o cometimento do crime, que amparava o modelo de intervenção positivista sobre o delinqüente, até então predominante.

Durante os anos em que o welfarismo penal teria vigorado, ainda segundo Garland, um verdadeiro complexo fora mobilizado no sentido de conformar a nova racionalidade que se atribuía à prisão, expresso por uma institucionalização técnica dentro e fora da prisão (psicólogos, assistentes sociais, educadores, agentes de probation, entre outros) contando-se ainda com o suporte das instâncias do Estado e de uma inteligentsia que se articulava na definição dos pressupostos teóricos e também mediante relativo respaldo popular.

Esse cenário vigorou, como demarcam os estudos contemporâneos (Garland, 2005; Wacquant, 2000; Bauman, 1999) até meados dos anos 70, quando a crise do welfare state promoveria um abalo em todas as instituições que o caracterizavam, sendo inevitável seus

\footnotetext{
${ }^{23}$ Prevalece em tais correntes, entre seus diferentes autores e teorias, a orientação crítica a respeito das abordagens tradicionais sobre a criminalidade, em especial as de caráter positivista e funcionalista. Destacamse a teoria das subculturas criminais e do labeling approach, sobretudo no âmbito da sociologia norteamericana. E. Sutherland e A. Cohen, como principais expoentes da primeira, aplicaram seus pressupostos em diferentes temáticas; enquanto Sutherland enfatizou aspectos dos mecanismos de controle e punição seletivos do Estado, tomando como objeto a criminalidade do colarinho branco (White-collor crimes) nas sociedades capitalistas do período, A. Cohen dedicou-se à análise das subculturas criminais em bandos juvenis, relativizando assim o conteúdo reprovador do desvio a partir do conjunto de valores próprios conformados por esses específicos grupos sociais. G.M Sykes e David Matza aprimorariam a teoria das subculturas criminais a partir de uma formulação que destacava o reconhecimento do sistema de valores vigentes pelo delinqüente, mas que explicava sua violação através do desenvolvimento, por ele, de formas específicas de justificação que operariam como "descriminantes oficias" ao comportamento delitivo. O pensamento de Sykes e Matza seria de grande influência para as abordagens científicas que o interacionismo simbólico e a etnometodologia desenvolveriam anos depois, e a partir das quais se situou a teoria do labeling approach, segundo a qual o comportamento criminoso deve ser compreendido a partir do processo de etiquetamento social definidor das concepções sobre o desvio e os desviantes, detendo seu objeto de análise, sobretudo, nos efeitos estigmatizantes desse processo na formação da identidade e na carreira moral dos criminosos. Seus mais destacados representantes são Howard Becker e Erwing Goffman. No âmbito da criminologia européia e latino-americana, a partir da década de 60, é de se destacar a corrente da criminologia crítica, que encontra seus fundamentos na teoria marxista do direito, sendo seu alvo de oposição o funcionamento do sistema penal, sua seletividade e a funcionalidade de sua operação para a manutenção das desigualdades sociais. Entre seus teóricos Alessandro Baratta, Rosa Del'Omo, D. Melossi e M. Pavarini (Baratta, 1999).
} 
reflexos no campo das políticas de controle e repressão ao crime, que, como já mencionado, haviam se desenvolvido a partir desse mundo social regulado.

A partir desse momento, o que se dará com a prisão serão movimentos aparentemente paradoxais. Seu intensificado uso, representado por crescentes e ainda ascendentes taxas de encarceramento no Ocidente a partir da década de $90^{24}$, indicarão seu emprego como instrumento privilegiado de contenção, direcionado - aí sem grande ineditismo - às classes populares, tal como demonstraram os estudos nessa área (Garland, 2005; Christie, 1998; Wacqüant, 2000).

O paroxismo reside, no entanto, primeiramente no fato de que a atualidade tem sido marcada pela crise da racionalidade disciplinar, através da constante reconfiguração das formas de regulação social, subordinação e controle, o que torna arcaico seu principal instrumento disciplinar, a prisão. No mesmo sentido, a descrença atual em se atribuir qualquer finalidade preventiva à prisão (quer na chave utilitarista, quer na da integração) é reveladora também do anacronismo de sua persistência e mais ainda, de sua intensificação. Desse modo, remanesce a questão de como o exemplar mais excelente desse mundo disciplinar em crise - a prisão - poderia ter não só se mantido ativo como ter seu uso incrementado. Certamente, não a partir dos mesmos significados e finalidades de outrora, mas recompondo aqueles que antes carregava.

\footnotetext{
24 A Europa apresentou, entre as décadas de 80 e 90, vertiginoso crescimento da população carcerária, citando-se os seguintes percentuais de aumento (entre os anos de 1983 e 1997): 43\%: Reino Unido, 39\%: França, 192\%: Espanha e 240\%: Holanda, (Wacquant, 2001:103). A experiência de encarceramento massivo norte-americana é ainda a mais emblemática: em 2001 apresentava a cifra de 2 milhões de encarcerados, o que representava à época uma taxa de 740 presos por 100 mil habitantes. Sob liberdade condicional e sursis encontravam-se cerca de outras 6 milhões de pessoas (Wacquant 2001:137). O Brasil, igualmente, tem aderido à política de encarceramento máximo: o número de presos dobrou entre os anos de 1995 e 2003 : 308.304 presos, uma taxa de 187,7 encarcerados para cada 100 mil habitantes (in: www.mj.gov.br/depen, acesso em outubro de 2004).
} 


\title{
3. A DERROCADA DO WELFARE STATE, A CRISE DAS DISCIPLINAS E AS NOVAS
} FORMAS DE CONTROLE: A PERDA DA DIMENSÃO INCLUDENTE

\author{
Se o objetivo oficial do welfarismo penal era a promoção do bem-estar social, o \\ interesse primordial atual é, despudoradamente, o eficiente fortalecimento do
} controle social.

(David Garland, La Cultura Del control, 2005:289)

O projeto ressocializador que a prisão assumiu a partir do século XX correspondeu a um programa, um discurso, mas não essencialmente por isso deixou de representar, em alguma medida, uma prática. De fato a idéia de inclusão é antitética à de prisão, uma vez que esta, desde sua gênese, sempre cumpriu a missão implícita de, como resumiu Foucault, “opor a plebe proletarizada à não proletarizada” (2000). E não fracassou nessa finalidade, de promover, no interior das classes populares, tal diferenciação invencível, a marcação subsistente a toda a vida do indivíduo uma vez encarcerado. Nesse sentido, é impensável qualquer política penitenciária includente, uma vez que, ontologicamente, ela sempre será excludente.

No entanto, compreendendo a existência de diferenciações que se realizam no nível dos discursos, e como já afirmado, também das práticas, é possível compreender que a ideologia da ressocialização penetrou o universo das representações e compôs tais práticas, assumindo contornos de uma política pública que, se não se define ontologicamente, ao menos se constitui, ainda que no nível da diferenciação a outros modelos, como includente.

Ou seja, é possível entender que a prisão pôde estar inscrita, durante algum tempo, dentro de uma lógica includente, na medida em que pressupunha o retorno do indivíduo, ainda que sob o signo do estigma, ao corpo social, quer como força de trabalho docilizada e barata, quer como qualquer outra forma aproveitável. Como já descrito, tal movimento integraria a mecânica de um mundo predominado pelo poder das disciplinas, sendo o papel das instituições essa modulagem e esse reaproveitamento, tendo em vista a extração da máxima utilidade econômica. O que se pretende compreender - e esse é, em essência, o problema de investigação até agora colocado - é como na transição e recomposição do poder disciplinar a outras formas de poder, pode-se definir o papel desempenhado pela 
punição, e compreender a persistência de seu exercício pelo instrumento disciplinador da prisão.

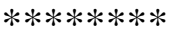

A partir da década de 70, o mundo ocidental capitalista assistiria a mudanças importantes nos cenários sócio-políticos e, sobretudo econômicos, iniciadas pela crise do petróleo de 1973 e pela forte recessão que a acompanhou. As mutações pelas quais o capitalismo passará a partir de então provocarão o redimensionamento da existência de um modelo de proteção e regulação social, centrado na figura de um estado providência, bem como da condição salarial como norma, e sua centralidade na configuração do mundo social.

A partir dessas reconfigurações, portanto, emergiram os pressupostos para o advento de uma nova política econômica e social, assentada em bases radicalmente antigualitárias: o neoliberalismo. Até a década de 70, o projeto neoliberal ${ }^{25}$ revelar-se-ia anacrônico, uma vez que as dinâmicas a partir das quais o welfare state se estruturara mantinham-se presentes: o crescimento econômico e a consolidação da relação salarial (Castel, 1999). A partir do momento em que tais dinâmicas passaram a se reconfigurar, a política neoliberal pôde se expandir de forma hegemônica pelo mundo capitalista, inclusive em países que jamais vivenciaram a experiência do estado de bem-estar social, como é o caso daqueles de capitalismo periférico.

A crise do estado de bem-estar social pode ser descrita, muito a grosso modo, como uma “interrupção de trajetória”, nos dizeres de Castel (1999), trajetória essa representada por alguns anos de estabilidade da norma salarial, amplitude da rede de proteção social do Estado e a conseqüente segurança social. Não há que se perder de vista, entretanto, como o

\footnotetext{
${ }^{25}$ Perry Anderson narra a "gênese" do pensamento neoliberal, ainda como um projeto visionário, a partir da publicação do texto de Friedrich Hayek, O Caminho da Servidão, em 1944. Naquela mesma década formouse um grupo de simpatizantes do ideário neoliberal, a Sociedade de Mont Pèlerin com o intuito de difundir o programa de promoção de um Estado capitalista "livre" das amarras protetivas e escravizantes do modelo keynesiano. Anderson demonstra que essas idéias foram gestadas durante décadas, desacreditadas enquanto a regulação estatal era consenso, para então emergirem como uma política de governo nos mandatos de Thatcher na Inglaterra (1979) e Reagan nos EUA (1980), ambos pioneiros na implantação da filosofia neoliberal como política de Estado (Anderson, 2003).
} 
autor aponta, o caráter inacabado deste modelo de Estado, suas contradições ${ }^{26}$, e ainda sua dimensão opressiva e normalizadora.

Do outro lado do Atlântico, as experiências quanto à configuração de um possível welfare state foram diferenciadas, não havendo, inclusive, como inscrevê-las nesta denominação. O Brasil, por exemplo, jamais vivenciou a generalização da norma salarial, a despeito da tradição paternalista em matéria de direito de trabalho, mas que, justamente por sua veia burocrática e especialmente autoritária, não constituiu a regulação pública democrática como norma.

Os EUA, por outro lado, por razões obviamente muito distintas as da América Latina, também nunca experimentaram um modelo de estado de bem-estar social propriamente dito. Sua forte tradição liberal, amparada no ideário da supremacia das liberdades e garantias individuais, nunca possibilitou que a matriz igualitária se configurasse e se impusesse como um princípio nacional. De tal modo, pode-se dizer que o Estado americano estruturou sua forma de intervenção social a partir de um modelo estadoprovidência residual (Titmus, 1969 apud Wacquant, 2000), outorgando sua assistência caso a caso diante de carências acumuladas e através de uma política de merecimento pessoal, fundada essencialmente no postulado da responsabilidade individual. Esse modelo estatal, nos dizeres de Wacquant, constituiria, quando muito, um verdadeiro Estado caritativo.

No entanto, a derrocada do welfare state coincide também com o declínio do estado caritativo norte-americano, passando esse a reequacionar cada vez mais a distribuição da riqueza social, comprimindo o orçamento destinado à ajuda social e condicionando-o a atributos de conduta pessoal (a vaga noção de merecimento) por parte de seus beneficiários.

É na emergência de um novo mundo social, assim, que é possível situar a crise das disciplinas. Partindo do pressuposto que as recentes mutações do capitalismo têm acarretado um deslocamento profundo na concepção hierarquizante que simbolizava a estrutura das relações de classe no modelo societário do tipo disciplinar, é preciso decifrar os tipos de mecanismos de controle e dominação que essa nova ordem tem instituído.

\footnotetext{
${ }^{26}$ R. Castel faz minuciosa análise sobre o significado da promoção da sociedade salarial, levando em conta inclusive suas contradições, como o fato de propiciar um tipo de individualismo a partir do esfacelamento de laços de solidariedade justamente em razão da forte presença do Estado. É o que ele denomina de efeitos homogenizadores poderosos (1999:507).
} 


\section{LIBERDADE E CONTROLE NUMA SOCIEDADE DUAL}

Gilles Deleuze se propõe a realizar, no texto Sociedade de Controle (1992), uma espécie de diálogo com a tipologia societária concebida por Foucault (2002 e 2003b) centrada na soberania, de um lado, e na disciplina e nos dispositivos gestionários sobre a vida (biopoder), de outro -, propondo a primazia, na atualidade, de um novo modelo que viria a ser as sociedades de controle. Tais sociedades se caracterizariam pela contínua flexibilização e desregulamentação das relações sociais, próprias de um tempo marcado pelo desengajamento em que as condutas não seriam mais passíveis de serem modeladas por sistemas estáticos e rígidos característicos da grande indústria, mas de se modularem pela lógica plástica das relações flexíveis próprias do mercado, não havendo como o poder disciplinar dar conta desse novo e complexo cenário.

Na esfera da punição, o repertório se atualizaria pela superação da pena de prisão enquanto modalidade de sanção penal por excelência; no lugar dela, identifica Deleuze, os mecanismos passíveis de exercer vigilância a céu aberto, como as pulseiras eletrônicas e as penas alternativas substitutivas à prisão, mas restritivas de direitos e moduladoras de obrigações e condutas a serem supervisionados. Nessa perspectiva, chega o autor a concluir pela definição da humanidade pós-disciplinar como composta de três quartos de pobres demais para a dívida, numerosos demais para o confinamento (Deleuze, 1992: 224).

Se o pensamento de Deleuze é elucidativo para a caracterização de uma nova ordem social na qual outros paradigmas têm se sobreposto ao modelo institucional de dominação, é certo, contudo, que remanescem, na esfera da punição, questões importantes sobre as finalidades que conformam o encarceramento na contemporaneidade. Pois, diversamente do que poderia se esperar de uma sociedade ancorada na primazia do controle, as sociedades ocidentais contemporâneas têm elevado o confinamento de segmentos populacionais a níveis nunca antes registrados.

No mesmo sentido, todo o aparato mobilizado ao controle social e à punição, ou ainda o modo de sua operacionalização - a constante seletividade de seu alvo e as altas e ascendentes taxas de encarceramento - sugerem, numa primeira análise, que a atualidade tem sido marcada pelo recurso intensificado aos mecanismos tradicionais das disciplinas 
junto às classes populares inscritas como perigosas: a vigilância e o confinamento. É certo ainda que esse controle revela-se como o outro lado de uma política de profunda retração no atendimento aos direitos sociais, própria de uma lógica de Estado centrada nos imperativos do mercado e da livre concorrência, expondo, nos dizeres de Castel (1999), a aporia que caracteriza tão singularmente a questão social na atualidade.

Um Estado que se revela, no topo, ultraliberal não só economicamente, mas a partir “da ideologia do merecimento e da responsabilidade individual” - a justificar uma retração ou subtração no atendimento aos direitos sociais - e paternalista punitivo na base, no estreito controle e vigilância exercido junto aos pobres, e, para além disso, garantindo, por seu adestramento, a resignação a um destino de precarização do mercado de trabalho e de subcondições de existência/sobrevivência (Wacquant, 2000).

A mesma fórmula apontada é defendida por Garland, que revela ainda como essa política tem produzido um modelo de sociedade dual, implicando a existência de um setor desregulado em nome da iniciativa de mercado e outro disciplinado em nome da moralidade tradicional (2005:176), referindo-se especialmente à população dos guetos norte-americanos para caracterizar esse último segmento. Liberdade para os investidores e controle para o imenso contingente de expurgados do mercado de trabalho e das “oportunidades” do mundo globalizado.

Mas é a partir da definição das finalidades sobre as quais esse controle se inscreve, que é possível desconstruir qualquer aproximação ao modelo das disciplinas consolidado no século XIX. Como já em 1979 apontaria Foucault, o neoliberalismo engendrou uma dinâmica social não mais pensada e voltada ao disciplinamento, o que equivale dizer que a sociedade contemporânea não tem mais nenhum desejo de obter um sistema disciplinar exaustivo (2004: 261), dispondo seus novos dispositivos de controle a partir de uma lógica puramente econômica, própria do mercado, na qual o que se visa é regular os níveis de oferta e demanda do crime, e não um projeto de disciplinamento, vigilância e reforma de indivíduos com o fim de extirpar a criminalidade.

Não obstante esse deslocamento implique em redefinições sobre o crime e a punição que abandonam o modelo panóptico, resultando, já esperadamente, em maiores níveis de tolerância ao cometimento de delitos, é certo que tal tolerância tem se traduzido de modo ainda mais seletivo, o que ajuda a explicar o incremento de legislações e medidas punitivas cada vez mais direcionadas a segmentos pobres da população, ou seja, às classes 
populares. Desse modo, tem-se toda uma mobilização e uma intensificação do estado penal como forma de responder às expectativas de redução da oferta de determinados crimes e, por conseguinte, às demandas punitivas da sociedade em geral, ausente qualquer outra finalidade de intervenção da pena sobre a figura do preso, como será discutido adiante.

Equivale dizer que a mudança de paradigma da disciplina ao controle, juntamente e isso é decisivo - ao abandono dos pressupostos de reintegração da prisão, não apenas não suprimiram como ainda intensificaram a seletividade de operacionalização do sistema penal. Isso redundou numa espécie de promoção diferencial pela via penal como um resultado da violência estatal dirigida a setores muito determinados da sociedade ${ }^{27}$, com destaque à população negra e pobre, em geral das periferias dos grandes centros urbanos.

No plano legislativo, as medidas de valorização do estado penal se inscrevem precisamente no contexto de derrocada do welfare state e de ascensão dos pressupostos do modelo econômico e político neoliberal, com suas principais manifestações a partir da década de 90. Até então, sobretudo durante os anos marcados pela estabilidade da norma salarial na Europa e pela predominância do modelo keynesiano de atuação estatal nos EUA, o campo das políticas de segurança pública e justiça criminal foi mobilizado, ao menos no âmbito legal, de maneira mais garantista ${ }^{28}$. Em alguns países como a Holanda e os países nórdicos, registrou-se, no período, o incremento de ideologias anticriminalizantes como o abolicionismo penal, na proposição da superação do direito penal como instrumento de regulação e repressão social, dada sua incapacidade de mediar os conflitos ou preveni-los (Hulsman, 1993).

Em meados da década de 80, já se conviveria com as primeiras medidas legais de endurecimento das políticas de segurança no mundo ocidental, revelando-se nas teorias conservadoras do tipo broken windows e tolerância zero ${ }^{29}$, bem como na revogação dos

\footnotetext{
27 A “promoção diferencial” dos negros ao sistema penal nos EUA é marcante: 9,4\% dos negros norteamericanos encontravam-se sob tutela penal em 1995 contra 1,9\% da população branca. Na Europa, esta alta incidência se refere aos imigrantes não ocidentais. A precarização do trabalho e a guerra às drogas são as importantes armas para essa discriminação no tratamento policial e judicial (Wacquant, 2001). No Brasil, tal “promoção diferencial” dos negros também encontra no sistema penal sua marca indiscutível, o que será demonstrado por dados empíricos a respeito da atuação da justiça criminal paulista no capítulo III.

${ }^{28}$ A corrente do garantismo penal, ou ainda do direito penal mínimo, define-se pela concepção do direito criminal mais como instrumento garantidor de direitos do acusado do que como um aparato punitivo a serviço do Estado (Ferrajolli, 1998).

29 A teoria da "vidraça quebrada" foi concebida em 1982 por James Wilson, um “intelectual” ultraconservador norte-americano; segunda ela, quem comete um pequeno distúrbio - ainda que não criminalizável - é passível de cometer quaisquer crimes, denotando ser portador de uma predisposição
} 
instrumentos legais que vigeram durante os anos do welfare state e sua substituição por uma legislação especialmente supressora de direitos dos acusados e presos e de agravamento das punições.

Na expressão do encarceramento massivo, a política de maior destaque é o conjunto de intervenções repressivas conhecida como guerra às drogas (Christie, 1998; Wacquant, 2000; Garland, 2005). Concebida nos EUA a partir de uma severa política de criminalização ao uso de drogas, a guerra às drogas tem sido responsável pela expansão do controle e encarceramento de contingentes massivos da população negra e pobre, além de se mostrar altamente dispendiosa e francamente ineficaz. Seus limites, no entanto, novamente extravasam o território de origem, para penetrar o campo do controle do delito em demais países, sobretudo na América Latina. Essa extensão se dá muitas vezes a partir de intervenções diretas na economia e na política criminal desses países, operacionalizando-se através do condicionamento da “ajuda” financeira, quer diretamente, quer através das agências internacionais e órgãos ligados a elas pelo financiamento de projetos de "redução de violência” nos países “em desenvolvimento”, a níveis de maior punitividade dos delitos relacionados a drogas. Desse modo, a política de guerra às drogas se internacionaliza junto a tais economias, provocando os mesmos efeitos devastadores sobre determinados segmentos sociais de cada nação.

O exemplo mais notório é o da Colômbia, país no qual a ingerência norteamericana tem ganhado contornos mais nítidos. No caso do Brasil, do mesmo modo, o cenário não é diferente: o governo brasileiro não só tem aderido aos programas que naturalmente condicionam o aporte de investimentos à adoção de indicadores de maior repressão e combate às drogas, como tem firmado sucessivos acordos diretamente com o governo norte-americano implicando em volumosos repasses de recursos à Polícia Federal nacional, mediante o cumprimento de “metas” pré-estabelecidas, como a exigência do incremento de prisões efetuadas e condenações por crimes relacionados a entorpecentes ${ }^{30}$, todas como medidas de “eficácia” ao controle de drogas.

patológica ao crime; essa teoria inspirou a difundida política de segurança “Tolerância Zero”, implantada pelo prefeito Rudolph Guiliani em 1993, segundo a qual as menores infrações devem ser punidas com todo o rigor com o fim de coibir o cometimento das mais severas (Wacquant, 2001: 23); essa política reativa e intensifica os talvez nunca extintos mecanismos de criminalização e punição dos comportamentos das classes populares, tendo se replicado como uma política de segurança pública por diversos países a partir da década de 90 .

${ }^{30} \mathrm{O}$ “Acordo de Cooperação Mútua para Redução da Demanda, Prevenção do Uso Indevido e Combate à Produção e ao Tráfico Ilícito de Entorpecentes” foi firmado entre o governo brasileiro e o norte-americano 
Desenvolvendo-se como um importante alicerce da política criminal contemporânea, a guerra às drogas não consegue atingir o núcleo central para o qual foi em tese concebida, a redução da oferta, ou seja, não logra combater a existência de organizações criminosas que operam o tráfico de drogas e suas raízes transnacionais. De outro lado, também não consegue atuar junto à outra ponta do processo, a redução da demanda, bem como ao intensificar a exclusão e segregação contínuas de segmentos da população jovem das periferias em diversos países, tem contribuído num sentido oposto ${ }^{31}$.

Têm-se assim, operando o sistema penal, de um lado os dispositivos não mais centrados nas disciplinas e na modelação, mas no controle e na modulagem, que se dirigem de modo seletivo a crimes e criminosos, e de outro, as elevadas e crescentes taxas de encarceramento e a maior severidade e crueldade de punições impostas aos presos concomitantemente à suspensão ou supressão de seus direitos civis e garantias individuais.

A persistência ainda de elementos que sugerem a naturalização de comportamentos desviantes e da pobreza ou que renovam um racismo na operacionalização dos sistemas punitivos, pode remeter, numa primeira análise, à persistência de elementos do próprio quadro de origem das disciplinas e das ciências criminológicas no século XIX. Contudo, a mudança de sentido empregado ao crime e, sobretudo, ao papel da pena de prisão, ou seja, o abandono de suas finalidades adestradoras, reintegradoras ou includentes na contemporaneidade, sugere que, ainda que se apropriando, em alguma medida, de elementos disciplinares, as práticas punitivas estão inscritas num quadro absolutamente novo e reconfigurado, sendo a recomposição de seus deslocamentos e de suas (novas) categorias operantes, o desafio para sua compreensão.

em sua primeira versão em 12/04/1995, sendo desde então e até o ano de 2001, renovado anualmente, segundo matéria da Revista Carta Capital, n 185 , de 17/04/2002. Segundo a matéria, e também mediante um Memorando de Entendimento entre esses dois países (MDE do ano de 2001) arquivado na SENAD/MJ, ao qual tive acesso, o acordo teria implicado na transferência pelos EUA, no ano de 2001, de US\$ 5.792.000,00 para "projetos" que se destinam a compra de equipamentos e fornecimento de estrutura material à Polícia Federal, até formação de agentes e policiais, através de cursos promovidos nos EUA. Um desses projetos, o Projeto B - Repressão e Treinamento da Polícia Federal dispõe expressamente como "método de verificação de progresso”, as “estatísticas de prisões e condenações relacionadas a entorpecentes” (MDE 2001).

${ }^{31}$ Sobre o empreendimento político da guerra às drogas nos EUA, Garland dispõe: Desafiando as evidências empíricas acerca de que os níveis de consumo de droga não estavam declinando, que o uso de drogas não se vê afetado pela imposição de penalidades, que a criminalização traz atreladas suas próprias patologias (...) e que declarar uma guerra contra as drogas é, de fato, declarar uma guerra contra as minorias, o governo dos EUA procedeu a declarar tal guerra e persistiu levando-a adiante, apesar de todos os indicadores de seu fracasso. Por quê? Porque os grupos mais adversamente afetados não têm poder político e são amplamente considerados perigosos e não merecedores de ajuda; porque os grupos menos afetados podem se sentir seguros porque algo se está fazendo e a ilegalidade não é tolerada... (2005: 224). 


\section{O APAGAMENTO DA FIGURA MORAL DO CRIMINOSO E A INCAPACITAÇÃo COMO FINALIDADE DO ENCARCERAMENTO}

Garland caracteriza a crise do welfarismo penal por uma série de transformações nos diversos âmbitos da vida social e nas práticas que redefiniram as políticas de prevenção e repressão ao crime, a partir dos anos 70. Identificando o declínio do ideal reabilitador, e diante das ascendentes taxas de encarceramento, superiores ao crescimento do delito (sobretudo nos EUA e na Grã-Bretanha), o autor aponta a uma reinvenção da prisão no mundo contemporâneo, agora como meio de incapacitação e castigo que satisfaz a demanda política e popular por retribuição e segurança pública, constituindo-se, ainda, em um pilar indispensável da ordem social contemporânea (2005: 51).

O que equivale dizer que a derrocada do welfare state e, por conseguinte, do welfarismo penal, trouxe consigo uma reformulação junto às categorias, representações e configurações que diziam respeito a uma agora já sobreposta ordem social, reescrevendo e modificando ainda seus dispositivos e arranjos institucionais que antes a conformavam. Decifrar as novas definições que foram sendo atribuídas aos atores e aos fenômenos sociais (como o criminoso, o delito e a punição), passa a ser a medida de inteligibilidade para esse novo quadro ainda em transformação.

Desse modo, identifica Garland, a crise do welfarismo penal teria vindo acompanhada de um novo e importante deslocamento no que se refere ao episteme criminológico que antes informava a política criminal e penitenciária social democrata, sobrepondo-se agora o problema do controle ao da privação para a explicação do crime. Antes de Garland, contudo, Foucault (2004), durante as aulas do curso ministrado no Collège de France entre 1978-1979, já havia, como mencionado, identificado uma importante mudança no tocante às concepções de crime, criminoso e punição introduzida pela racionalidade neoliberal ${ }^{32}$, que tenderia a inserir a problemática do crime dentro da lógica econômica dos riscos e assim convertendo o problema da punição mais num problema do controle que deveria incidir, não sobre indivíduos, mas sobre o mercado de oferta e demanda de crimes. Em sentido similar, a também já mencionada perspectiva de

\footnotetext{
${ }^{32}$ Foucault toma como referência o artigo denominado Crime et châtiment, do neoliberal Gary Becker, que
} oferece nova formulação ao conceito de crime, a partir do qual Foucault desenvolverá sua linha de análise. 
Deleuze (1992) sobre a superação do paradigma disciplinar através da ascensão do que ele denominou sociedades de controle.

Se o problema do controle trouxe novas fórmulas para o enfrentamento do crime essencialmente baseadas na esfera da previsão dos riscos e, assim, da valorização de uma política de prevenção ao crime que conta ao mesmo tempo com uma lógica de privatização da segurança e de maior envolvimento da sociedade nesse campo ${ }^{33}$, de outro lado, o aparato repressivo estendeu consideravelmente seus limites, não apenas a partir do incremento de seu emprego, como pela maior severidade dos castigos impostos.

Ao se liberar assim dos compromissos firmados por uma política que pregava a responsabilidade do Estado em reintegrar socialmente aqueles que haviam sido insuficientemente socializados, abriu-se espaço para que a natureza puramente retributiva da pena assumisse lugar. As novas feições retributivas atribuídas do cárcere, contudo, nada se assemelham ao paradigma clássico liberal do direito penal; na atualidade, entretanto, o ideal retributivo assume feições de vingança e expressividade, distantes do estatuto liberal que buscava em sentido oposto uma medida de proporcionalidade entre o crime e a pena e assim impor os limites à atividade punitiva.

Aqui a formulação é inteiramente diferente, prevalecendo dispositivos da soberania, essencialmente representados no caráter expressivo ${ }^{34}$ das punições e em sua desvinculação a qualquer lógica utilitarista; uma resposta austera e sem qualquer eficácia para o fim da contenção da criminalidade, amparada no elemento puramente simbólico da demonstração da força e no mito do restabelecimento da ordem por essa manifestação. Do mesmo modo, o oferecimento de respostas emergenciais ao delito, a partir de uma inflação legislativa que visa à contínua supressão dos direitos e garantias dos acusados e presos, é revelador do

\footnotetext{
${ }^{33}$ Apesar da aparente ambivalência, essas práticas têm marcado a contemporânea política criminal tanto em países de capitalismo avançado (como o trabalho de Garland demonstra) como nos periféricos. Ambas as manifestações estão inseridas dento de uma lógica de retorno à privatização do conflito, podendo-se identificar a ausência de atuação ou mediação do Estado tanto no incremento da indústria do controle do delito (privatização dos serviços de segurança e punição), quanto pelas práticas que propõem uma maior participação da comunidade na resolução de conflitos, como a mediação, a justiça restaurativa e o policiamento comunitário.

${ }^{34}$ Garland recorre aos exemplos mais evidentes de sanções de caráter expressivo nos EUA: as leis que obrigam a marcação pública ao indivíduo que já foi condenado por crime sexual, ou mesmo a existência e persistência de castigos corporais e da pena morte; indica também um conjunto de medidas altamente supressoras de direitos como a de condenação mínima obrigatória, o three strikes you are out e a prisão perpétua, como medidas que denotam o caráter "absolutista" através do qual o Estado lida com o problema do delito, além de revelar como o mesmo recorre a um espetáculo de força punitiva contra certos indivíduos para reprimir qualquer tipo de reconhecimento da incapacidade do Estado para controlar o delito em níveis aceitáveis (2005: 226).
} 
caráter populista do qual a política criminal contemporânea tem se revestido, e, mais que isso, da dimensão totalitária dessa intervenção (Garland, 2005).

Portanto, com o abandono do conjunto de referências que tinham, quer na perspectiva interventora assistencialista, quer naquela mais emancipatória de reintegração com reconhecimento de direitos aos presos, sua representação maior, abriu-se caminho para que uma nova racionalidade penal fosse instaurada, na qual as formas de suspensão de direitos por uma "permanente exceção" podem ser invocadas em nome do princípio da (in)segurança. Dessa forma, perde sentido qualquer intervenção penal que vise à reintegração ou mesmo à coibição de futuros crimes, pois o que resulta mesmo e deve resultar é a incapacitação, a neutralização do criminoso e o cancelamento de seu estatuto de sujeito de direitos.

A presença da categoria exceção na descrição das políticas de repressão e controle do crime não se encontra expressamente descrita no trabalho de Garland, mas o recurso que o mesmo faz, para descrever as práticas penais na atualidade, às duas outras noções trabalhadas pelo filósofo Giorgio Agamben na compreensão da estrutura e operacionalização do estado de exceção, torna possível uma certa analogia entre as obras.

Agamben, dialogando com Foucault e H. Arendt, propõe uma investigação acerca do "significado biopolítico do estado de exceção" a partir de sua relação com a soberania e com a produção da vida nua, a vida exposta à morte e insacrificável do homo sacer(1998: 17). O autor foi buscar, no direito romano arcaico, essa figura que representa aquele que pode ser morto sem que sua morte configure homicídio, sacrifício ou a execução de uma pena, operando-se nele e através da exceção soberana que nele incide uma dupla exclusão: da jurisdição humana e da divina (1998:82-83).

Agamben recorre a essa apropriação originária da vida à compreensão da gênese da soberania e sua relação com o estado de exceção, entendido esse como a suspensão das relações de direito e, em última análise, da configuração do sujeito de direito, se realizando não de fora, mas a partir mesmo do próprio direito ${ }^{35}$. Para ele, o que caracterizaria a política moderna ocidental não seria o ingresso da vida no centro da política (a biopolítica),

\footnotetext{
${ }^{35}$ Agamben recorre especialmente à doutrina de Carl Schmitt sobre a soberania na formulação de que a relação de exceção não é exterior à ordem jurídica, mas um estado de suspensão da norma, declarado pelo soberano que em verdade constitui a ordem. Esse aparente paroxismo é superado pelo fato de que $o$ soberano, através do estado de exceção, cria e garante a situação de que o direito tem necessidade para poder vigorar (1998:26), sendo a exceção assim a estrutura originária na qual o direito se refere à vida e a inclui através de sua própria suspensão (1998:36).
} 
como defendeu Foucault (2001b), mas o fato da soberania ou o poder soberano, presentes indistintamente em regimes totalitários e democráticos, de direita e de esquerda, acionarem os dispositivos de suspensão de direitos e da ordem jurídica (produção da vida nua) a partir da relação de exceção, de modo a que o espaço da vida nua, situado originalmente à margem da ordem jurídica, vir progressivamente a coincidir com o espaço político (1998:18).

Agamben visualiza, na partilha entre o "humanitário e o político" dos campos de concentração nazistas e de refugiados da atualidade, a fase extrema entre a separação dos direitos do homem e do cidadão (1998:130) e um exemplo eloqüente da produção da vida nua, na qual a exceção é acionada por todos os lados. É, contudo, na mais contemporânea política de ordem norte-americana representada pelo USA Patriot Act, de outubro de 2001, e na figura dos estrangeiros suspeitos de participação em atos terroristas detidos em Guantánamo, que o autor, em um trabalho mais recente (Estado de Exceção, 2004) visualiza a vida nua na sua máxima indeterminação (2004:15).

Que a soberania ou os poderes soberanos sejam acionados a partir mesmo da estrutura democrática do Estado, e que eles venham se mostrando mais eloqüentes justamente no país que mais consagra os valores da liberdade e da democracia, como é o caso dos EUA, é bastante sintomático do papel central exercido pelos dispositivos de exceção como instrumental necessário à partilha definidora da exclusão, ou seja, da vida nua, na política contemporânea. E é precisamente no campo das práticas penais que toda essa realização (jurídica) se apresenta com maior nitidez, sendo na esfera da punição que o arcaico e o contemporâneo se conjugam ao delineamento mais preciso da figura do homo sacer, representado na nova construção moral acerca do criminoso, com a abolição das concepções reintegradoras da prisão.

A existência de figurações a respeito do delinqüente que o destacam a partir de sua “perversidade”, “má índole”, e, sobretudo nas concepções de “oportunismo” e “irrecuperabilidade”, podem ser identificadas nas principais representações das correntes criminológicas que Garland (2005) atribui de antimodernas, e que estariam na base tanto de políticas repressivas do tipo tolerância zero, como, e, principalmente, das medidas punitivas de maior impacto (pena de morte, castigos corporais, etc), todas elas operacionalizadas a partir da declarada suspensão de direitos dos criminosos e presos. 
Garland identifica, contudo, de modo concomitante, um outro movimento criminológico contemporâneo, aparentemente em tensão com o modelo conservador, que ele denomina de criminologias da vida cotidiana, de característica tardomoderna, nas quais o episteme do controle tenderia a esvaziar qualquer conteúdo normativo em respeito ao crime bem como em relação à figura criminoso, restando a questão da minimização de riscos e de oportunidades ao cometimento dos delitos como central na sua proposição. Daí, a figura do criminoso ser definida não a partir de um conteúdo moral nem valorativo, que não se dirige nem ao passado - os condicionantes do crime, seu contexto - e muito menos para o futuro - possibilidade de reintegração -, remanescendo a imagem do delinqüente como o homem situacional.

A identificação dessa “corrente criminológica” corresponde, em verdade, à descrição sobre a introdução da racionalidade neoliberal na estrutura e no funcionamento do sistema penal contemporâneo, feita por Foucault (2004) no já mencionado curso de 1979. Já àquele momento, ele havia identificado como a lógica econômica adentrara os domínios da racionalidade jurídica criminal para, realizando com plenitude o sonho dos reformadores do século XVIII, introduzir de modo preciso o cálculo e a lógica utilitarista nos domínios jurídicos. Só que, à diferença dos reformadores liberais, essa nova racionalidade econômica não visava agora à completa extinção da experiência do crime, senão, como já apontado, uma mera regulação sobre o mercado de oferta e demanda do delito.

Por conseguinte, impôs-se assim uma nova formulação ao conceito de crime ${ }^{36}$, não mais como um ato que é assim definido a partir de sua punição (como a definição dos códigos penais em geral), mas sim como aquele sobre o qual possa recair o risco da punição. Em decorrência, e esse é ponto que mais interessa aqui, a reformulação do conceito de criminoso, ou antes, os parâmetros a partir dos quais ele passa a ser definido, com o que se assistirá, nos termos de Foucault, ao apagamento antropológico do criminoso, ou seja, o sistema penal, ao não se ocupar mais do crime como uma conduta de conteúdo moral, esvaziou também esse conteúdo da própria definição acerca do criminoso e da intervenção que sobre ele incide. Esse novo arranjo teria promovido, enfim, o deslocamento do homo criminalis para o homo øconomicus, delineando-se sua imagem como aquele que aguarda os lucros e que aceita os riscos de uma perda (Foucault, 2004:

\footnotetext{
${ }^{36}$ Foucault toma aqui em estritos termos a definição dada por Gary Becker.
} 
258-259) aproximando-se assim da formulação do homem situacional, feita por Garland (2005).

Ao se extrair qualquer conteúdo ético também da pena, convertendo-a em uma medida de regulação num mercado de oferta e demanda do crime, toda a lógica informadora do sistema penal e sua operacionalização foram redesenhadas, importando daí duas ordens de conseqüências. Uma delas se refere a essa nova mecânica essencialmente econômica atribuída à punição, resumida pelo neoliberal Gary Becker aos níveis de delito e punição que uma sociedade estaria disposta a tolerar, bem como aos seus respectivos custos (Foucault, 2004). Embora essa operação regulatória seja traduzida por Becker em termos estritamente quantitativos, ela não esconde uma seleção absolutamente qualitativa, na medida em que não se trata apenas de quantos delitos se vai tolerar, mas, como já apontado, de quais condutas se admite tolerar. Essa nova perspectiva econômica não deixou assim de produzir formas de controle e punição seletivamente distribuídas entre a sociedade, o que pode ser claramente constatado a partir das políticas conservadoras que têm predominado no cenário de repressão ao crime a partir da década de 90, como “tolerância zero”, “teoria das vidraças quebradas” (broken windows), entre outras.

A segunda conseqüência dessa nova tecnologia da punição é aquela que remete ao outro padrão de representações sobre o delinqüente, retomando em alguma medida o conteúdo moral das disciplinas, mas não necessariamente antropológico, representado pelas já citadas figurações de “má índole”, “perversidade” e “irrecuperabilidade”, identificada por Garland como uma criminologia antimoderna. A questão é que ambas as representações - o homem situacional e o perverso inescrupuloso - longe de se referirem a duas correntes criminológicas em oposição, como sugere Garland, se revelam, ao contrário, complementares, prestando-se ainda a uma mútua funcionalidade. Ambas, como reconhece o próprio autor, partem de um mesmo pressuposto, que é a negação das políticas criminais associadas ao welfarismo penal, ou seja, a rejeição a qualquer perspectiva reintegradora da prisão. Para além, ambas são fruto de um mesmo fenômeno que foi descrito por Foucault como a inserção e o predomínio da racionalidade econômica (neoliberal) nos domínios jurídicos que moldavam a estrutura e o funcionamento dos sistemas penais, ou seja, ambas as "correntes" decorrem e se desenvolvem a partir do esvaziamento moral do conceito de crime, criminoso e punição. 
Com esse esvaziamento, abriu-se caminho não apenas para que a pena pudesse ser concebida sem um conteúdo moral, mas para que a intervenção penal não estivesse pautada tendo como referência o sujeito. Com isso, além de se apagar o criminoso antropologicamente, esvaeceu-se também sua configuração como “sujeito de direitos”, que o welfarismo havia especialmente formulado através de sua inclusão numa ordem social que era concebida não apenas por medidas de proteção social, como também de atribuição de direitos. Esse apagamento do criminoso também como sujeito (de direito) tende a se realizar na ordem contemporânea de modo cada vez mais intenso, pela suspensão gradativa de seus atributos, garantias e direitos operacionalizada pelos dispositivos soberanos e de exceção.

Como homem situacional ou indivíduo perverso e monstruoso, a prisão incidirá sobre ele tendo em conta a idéia de sua irrecuperabilidade, proporcionando por isso um desmonte gradativo sobre o estatuto jurídico que em torno dele um dia se construiu, de modo que sua existência venha se assemelhar cada dia mais à figura do homo sacer, numa feição contemporânea.

Essa configuração, antes de parecer radical ou até anacrônica num tempo em que a experiência democrática já estaria consolidada em boa parte do Ocidente, evidencia o quanto o paroxismo que recai sobre sociedades que um dia conjugaram o poder soberano e o biopoder - como aponta Foucault (2002) quando se refere a regimes totalitários como o nazismo -, pode ter permanecido na lógica de funcionamento de muitos Estados, encontrando no campo das práticas punitivas uma possível demonstração dessa conjugação.

O próprio campo informador do direito penal tem sofrido, na atualidade, deslocamentos importantes que apontam e autorizam, sem constrangimentos, o emprego de categorias como a exceção e a vida nua nos fundamentos e na dinâmica de aplicação dos dispositivos jurídicos do sistema penal.

O texto paradigmático do jurista alemão Günther Jackobs, Bürgerstrafrecht und Feindstrafrecht, escrito em 2002 e traduzido para o espanhol em 2003 como Derecho 
Penal del enemigo y Derecho Penal del cuidadano, defende, tal como sugere o título, a coexistência de dois mecanismos repressivos no Estado penal contemporâneo: um para os cidadãos e outro para aqueles considerados inimigos, ou seja os indivíduos que não permitem sua inclusão em uma constituição cidadã (Jackobs, 2003:48).

Os inimigos a quem o autor se refere expressamente são aqueles que põem em risco a segurança pública, a quem ele denomina como terroristas. Essa formulação vai ao encontro da polarização vivida nos últimos anos entre os EUA e o Islã, fazendo coro à simplificação maniqueísta norte-americana para o contexto geopolítico: a divisão entre o Mundo do Bem (os cidadãos, especialmente os norte-americanos e seus aliados) e o Eixo do Mal (os inimigos). Referida construção jurídica autoriza ainda que em relação aos inimigos incida uma série de sanções que um dia puderam ser classificadas como cruéis e aflitivas, que nada se relacionam ao tradicional poder disciplinador da prisão, embora nela se operacionalizem, à diferença da exposição pública dos castigos e execuções do mundo soberano.

Como idealizador dessa nova formulação teórica que vem sendo denominada direito penal do inimigo, Jackobs promove a ruptura com toda a tradição liberal que informou o direito penal ocidental, implodindo o mito da igualdade formal na teoria deste direito introduzido pelas revoluções liberais do século XVIII. Por outro lado, ao dar corpo e expressão à segregação e ao tratamento diferencial de indivíduos no interior das regras do direito penal, rompe ainda com a tradição universalista dos direitos humanos, que vigorou, também no plano formal, no mundo ocidental desde o fim da $2^{\mathrm{a}}$ Guerra Mundial.

Nesse sentido, é possível compreender por que as categorias cognitivas vida nua, soberania e exceção, pensadas por Agamben para elucidar a política contemporânea, encontram no campo das práticas punitivas um significado mais evidente. São elas que, do mesmo modo, permitem que não apenas se possa avançar no debate acerca da reinvenção da prisão na atualidade, como ajudam a compreender, em última análise, o esfacelamento de categorias fundantes da modernidade tal como o Estado de direito, bem como apontam ao contínuo apagamento de seu principal protagonista, o sujeito de direitos. 
SEGUNDA PARTE: O SISTEMA PUNITIVO NO BRASIL CONTEMPORÂNEO 


\title{
CAPÍtulo II
}

\section{A TRANSIÇÃO DEMOCRÁTICA E A REFORMA PENAL DOS 80: O TARDIO INGRESSO DO IDEAL RESSOCIALIZADOR}

\begin{abstract}
SUMÁRIO: 1. O debate sobre as prisões nos 80: o resgate da política; 2. A jurisdicionalização na execução da pena: uma disputa pelo estatuto jurídico do preso; 3. A CPI do sistema prisional, o novo Código Penal e a primeira Lei de Execuções Penais - LEP; • O processo de institucionalização do debate sobre a questão carcerária (1975-1984); • A LEP e sua negação; 4. A política de humanização das prisões em São Paulo e seu desfecho: a negação de direitos; • Os precedentes: a gestão Manuel Pedro Pimentel (1975-79); • As medidas de humanização da gestão José Carlos Dias e sua oposição (1983-86).
\end{abstract}

A política existe quando a ordem natural da dominação é interrompida pela instituição de uma parcela dos sem-parcela. (...) Fora dessa instituição, não há política. Há apenas ordem da dominação ou desordem da revolta. (Jacques Rancière, O desentendimento, 1996:26-27)

\section{O DEBATE SOBRE AS PRISÕES NOS 80: O RESGATE DA POLÍTICA}

A crise do mundo disciplinar e daquilo que os especialistas irão denominar do “ideal ressocializador” da prisão é identificada, no âmbito dos países ocidentais de capitalismo avançado, a partir dos anos 70, consentânea à crise do estado de bem-estar social e ao desenvolvimento das políticas neoliberais, cenário já descrito no capítulo I.

A partir dessa década, uma nova racionalidade penal começa a se delinear, marcada pela reconfiguração do campo das práticas de controle e das instituições responsáveis pela aplicação da lei e pela justiça criminal, tendo, entre os pressupostos, referida mudança de paradigma na finalidade da prisão, identificada de modo uníssono pelos estudos que têm pretendido compreender essas transformações (Garland, 2005) ainda que guardem entre si metodologias e conclusões não absolutamente consoantes (Christie,1999; Wacquant, 2000).

No Brasil, diferentemente, a passagem dos 70 para os 80 foi marcada por acontecimentos que representaram a luta pela restituição da fala e do espaço da política (Oliveira, 2000) no cenário social e político, subtraídos pelos anos da ditadura militar que ainda prolongava sua existência. A transição do Estado autoritário para o democrático foi 
um processo gestado por alguns anos de lutas e negociações, consistindo a reorganização e a recuperada autonomia do movimento sindical bem como a constituição dos novos movimentos sociais e populares nas maiores expressões desse processo, sobretudo por representarem a emergência de reivindicações por direitos de diversas ordens a amplos segmentos sociais.

Sem dúvida o declínio da ditadura militar não pode ser tributado apenas a referidas forças sociais, tendo sido registrado um desgaste contínuo nas bases que sustentaram o governo, ou seja, um gradativo afastamento das forças oligárquicas que promoveram o golpe, mas não o geriram, o que Oliveira (2000) denominou de crise de hegemonia do regime militar nunca resolvida e que ocasionou o previsível desdobramento de sua erosão. A organização e a mobilização das antes mencionadas forças sociais, no entanto, tiveram um importante papel não apenas em alavancar tal derrota, mas em compor a teia que conduziria à reconstrução do espaço da democracia, sobretudo através da agenda de reivindicações que pôde pautar a assembléia constituinte, e o conteúdo da Carta Maior promulgada em 1988, com conseqüências para diversas esferas da vida social e para o funcionamento das instituições.

É tal dimensão de atuação que interessa aqui reter, bem como o impacto que tiveram essas lutas para que um ideal que já se encontrava em declínio em boa parte do mundo - o ideal reabilitador da prisão - pudesse encontrar, nesse preciso momento histórico no país, fôlego para se impor como uma reivindicação, ou ainda como um paradigma de intervenção do Estado com relação ao criminoso.

As mobilizações para a libertação dos presos políticos e sua anistia, uma das mais importantes bandeiras pelo fim do regime militar, foram os primeiros movimentos a lançar luz sobre a realidade das prisões, ainda que priorizando um público que lá se encontrava circunstancialmente encerrado. Entre as organizações, a Comissão Justiça e Paz de São Paulo, a Pastoral dos Direitos Humanos e do Marginalizados da Arquidiocese de São Paulo, a Ordem dos Advogados do Brasil - OAB, além de vários grupos de intelectuais e políticos de centro e esquerda no país (Caldeira, 2003).

Num momento posterior, já no início da década de 80 , outros movimentos e associações se formariam e se articulariam em São Paulo, agora para a denúncia da realidade enfrentada e das violações dos direitos sofridas pelos presos comuns, introduzindo ainda o debate da seletividade do controle penal e do estigma recaído sobre a 
população pobre das periferias urbanas, cliente preferencial da atuação policial, como centrais na compreensão do arbítrio e da violência promovidos pelo sistema criminal.

Em 1981 era realizado, em São Paulo, um debate organizado pelo IEE - Instituto de Estudos Especiais da PUC/SP e pela Pastoral de Direitos Humanos da Arquidiocese de São Paulo sobre a questão carcerária, resultando na formação do Grupo de Trabalho sobre a Questão Carcerária, congregando diversas entidades a partir de encontros e ações realizadas entre os anos de 1981 a 1983. Seu foco se estabeleceria em torno da discussão e da proposição de reformas para o cárcere, tendo em vista a perspectiva do atendimento aos direitos dos indivíduos encarcerados. Entre as instituições que integraram o Grupo, estiveram o Centro Santo Dias de Direitos Humanos, a Organização Comunitária pelos Direitos dos Presos, a Pastoral Carcerária, a OAB, os Centros Acadêmicos e Departamentos Jurídicos de Faculdades de Direito e, após sua fundação em 1983, a Comissão Teotônio Vilela para Prisões e Instituições Fechadas (Queiroz, 1983; Pinheiro e Braun, 1986).

Além das entidades, os debates reuniram políticos, intelectuais, Secretários de Estado, dirigentes de estabelecimentos prisionais, juízes e militantes ${ }^{37}$, numa experiência inédita na história do país, em que se sentaram lado a lado a sociedade civil e o Estado no esforço de politizar a questão carcerária, ou seja, resgatar, enquanto conflito social, sua potência política (Telles, 2003) e, nos termos de J. Rancière, o quanto ela pode representar de dissenso (Rancière, 1996).

Esse quadro confere a dimensão, portanto, que, de forma inaugural na história brasileira, o debate sobre as prisões e enfim sobre a atuação coercitiva do Estado alcançava setores mais ampliados da população - em muito facilitado, é certo, pelo momento de abertura política e de inserção de pleitos nunca antes reivindicados - inscrevendo-se a questão carcerária, de forma inaugural, como uma questão política e polemizável a partir da própria sociedade ${ }^{38}$.

\footnotetext{
${ }^{37}$ A síntese dos seminários, junto às conclusões do Grupo sintetizadas a partir de um documento base para a “Organização Comunitária dos Presos” - um verdadeiro manifesto contra as prisões - foram reunidas e organizadas por José J. Queiroz resultando numa publicação pelo IEE de 1983. Nos debates, estiveram presentes Paulo Sérgio Pinheiro, José Carlos Dias (antes e depois de ser nomeado Secretário de Estado), Plínio de Arruda Sampaio, D. Paulo Evaristo Arns e autoridades ligadas à execução penal como o juiz corregedor dos presídios à época, Secretários de Estado, entre outros (Queiroz, 1983).

38 Zaluar (1999), na revisão elaborada sobre o tema da violência e do crime na literatura especializada nacional, menciona a formação de uma Comissão ligada ao Ministério da Justiça e integrada por cientistas sociais e intelectuais de áreas diversas ao Direito e à Medicina, com a finalidade de promover um estudo e um diagnóstico sobre a criminalidade no país. A formação dessa Comissão, da qual fez parte o sociólogo José Arthur Rios, conferiu a dimensão, segundo a autora, de como o debate sobre o tema passava a extravasar os
} 
A criação da Comissão Teotônio Vilela no período pôde representar, no mesmo sentido, a importância que a temática vinha ganhando no debate público, implicando sua atuação um extenso rol de denúncias e intervenções contra as diversas manifestações do estado autoritário como: a violência policial, a violência no campo, as ilegalidades das prisões cautelares, a prática reiterada da tortura nos estabelecimentos carcerários, enfim uma série de arbitrariedades que sempre permearam as práticas de controle e repressão no país, desde muito antes do golpe militar.

Consentâneos a tal movimento e, ao mesmo tempo implicados e decorrentes de sua gênese, registraram-se duas dimensões de mudanças nas políticas de Estado. Numa esfera, o debate legislativo iniciado ainda antes, em meados da década de 70, pela CPI do sistema penitenciário nacional, que teve como desdobramentos a promulgação da primeira lei de execuções penais no país e a reforma do código penal em 1984; já no âmbito da execução de políticas para o cárcere, a política de “humanização das prisões” levada a cabo no governo eleito de Franco Montoro no Estado de São Paulo, pelo então Secretário de Justiça José Carlos Dias.

Não obstante a defasagem histórica de algumas décadas, verificava-se, no Brasil, no plano das políticas do Estado, a preocupação com um sistema carcerário que conferisse um rol mínimo de direitos aos indivíduos presos e que não os incapacitasse para a vida em liberdade no futuro, algo que já era experimentado em grande parte dos países da Europa pelo menos desde os anos 60, com o avanço das teorias garantistas no direito penal, da criminologia progressista e até de correntes como o abolicionismo penal. Nos termos das Regras Mínimas das Nações Unidas para o Tratamento de Reclusos aprovada em 1955, o Brasil da transição democrática vivenciava, mais de vinte anos depois, a idéia de que os presos seriam também portadores de direitos humanos, e debatia como seria possível uma política penal que ao mesmo tempo prevenisse crimes e reprimisse criminosos com a perspectiva de sua ressocialização.

Portanto, quando o ideal ressocializador da prisão já entrava em declínio em boa parte das nações de capitalismo avançado (Garland, 2005), encontraria ainda no Brasil do início dos anos 80 seu último - e breve - sopro de existência. As razões para essa defasagem precisam ser entendidas no âmbito da história das práticas de controle e repressão, das instituições totais e do tratamento da questão social no país.

campos a ele tradicionalmente restritos, além de demonstrar a importância que a questão do crime e da violência vinha ganhando no plano institucional federal (1999:29). 
Iniciada em 1975, a Comissão Parlamentar de Inquérito Destinada a Proceder ao Levantamento da Situação Penitenciária do País realizou-se ainda sob os anos "de chumbo" da ditadura militar. Destacou-se como figura central da CPI o deputado federal Ibrahim Abi-Ackel, relator da Comissão, parlamentar da Aliança Renovadora Nacional Arena -, partido político que reunia as bases aliadas do regime, ou seja, a ostensiva direita no país. Ibrahim conduziria, junto ao presidente da Comissão, José Bonifácio Neto, todas as respectivas sessões, revelando especial empenho e determinação à consecução das finalidades propostas por essa ${ }^{39}$.

As referidas finalidades foram definidas por ele numa das sessões a partir das preocupações inspiradoras da comissão:

Como levar o Governo a dar ao presidiário um tratamento que melhore sua educação? Como levar o Governo a dar ao presidiário um tratamento correto, a fim de que ele saia de lá com uma escolaridade maior do que a que ele possuía ao ali penetrar, um tratamento que lhe permita trabalhar durante todo o período de cumprimento da pena? (Diário do Congresso Nacional 04/06/1976 suplemento p. 15).

Ou em outro momento, ao debater com o jurista Virgilio Donnici, expondo a filosofia sobre o sistema penitenciário que a CPI adotava:

...chegamos à conclusão de que sua filosofia é precisamente a da Comissão Parlamentar de Inquérito do Sistema Penitenciário, ou seja, a de que as penitenciárias não foram instituídas para a punição e nem para o aperfeiçoamento da reincidência, como escola superior do crime, mas como algo destinado a recuperar no detento aquelas condições de sociabilidade que possam fazê-lo retornar ao seu meio, como um elemento válido de produção de riqueza e

\footnotetext{
${ }^{39}$ Sempre que um convidado às sessões da CPI, geralmente um especialista, colocava em dúvida a finalidade prática da CPI e seu êxito em propor soluções efetivas para o sistema penitenciário, Ibrahim era o primeiro a defender, de modo por vezes veemente, o papel da Comissão.
} 
de melhoria do nível de vida. (Diário do Congresso Nacional 04/06/1976 suplemento p. 14).

Consistia uma tarefa desafiadora, para um parlamentar do regime, antes da abertura, propor reformas que atingissem ao mesmo tempo o sistema de controle social (a polícia) e o aparato repressivo (o sistema de penas e sua aplicação) de um estado autoritário, sem tocar em questões centrais para a existência deste estado. Para tanto, a agenda da CPI previa além de visitas e inspeções, a presença de especialistas (advogados, juristas, professores) na abertura das sessões, com o objetivo de introduzir os problemas e as propostas sob um prisma que o deputado denominou de “objetivo”, ou seja, sob o manto da ciência.

Sob o signo formal e aparente do reformismo, as discussões não escaparam, contudo, a conteúdos bastante polêmicos e colidentes com o sistema penal e com o próprio regime como: a violência e a corrupção da atividade policial, a necessidade de descriminalização de uma série de condutas como a vadiagem e outras contravenções penais, a falta de independência do Judiciário, o estigma do preso e do egresso na sociedade e, o mais tocado, as péssimas condições das prisões no país.

O relatório das conclusões da Comissão, publicado em 1976, elegeu alguns pontos como centrais para uma reorientação da resposta penal no país: i) a individualização da pena - como forma de classificação inicial e tratamento diferenciado -, com vistas à reintegração social do preso; ii) a introdução de medidas desprisionalizadoras como a regulamentação da prisão-albergue ${ }^{40}$, a criação de um sistema de penas alternativas e a efetiva progressividade de regimes da pena, como conseqüência da individualização; iii) um rol de medidas garantidoras de direitos dos presos como assistência jurídica nos presídios, garantia do trabalho e cobertura pela previdência social, assistência ao egresso entre outros; e, finalmente, iv) a autonomia da execução penal e seu tratamento jurídico a partir de um estatuto legal que não mais restringisse a matéria à regulamentação tãosomente administrativa, o que representaria a definitiva colocação do problema carcerário

\footnotetext{
${ }^{40} \mathrm{O}$ instituto da prisão-albergue, correspondente a uma modalidade de cumprimento de pena em regime aberto em casa do albergado, era um antigo projeto do então Secretário da Justiça do Estado de São Paulo, Manuel Pedro Pimentel, encampado pelo ordenamento jurídico em 1977 através da Lei no 6417. No estado de São Paulo, contudo, o instituto já era previsto e regulamentado pelas Resoluções do Conselho Superior da Magistratura desde 1965.
} 
na arena do conflito, onde, ao menos em tese, os direitos podem ser discutidos e as ações publicizadas.

Esse último ponto, que resulta da constituição da figura do sujeito de direito, eixo central (e de disputa) no mundo liberal republicano, passou nesse momento da história da execução penal brasileira a ser a pedra angular no modo de se conceber a questão penitenciária. Para tanto, entrava em cena o conceito, nada inédito é verdade, de jurisdicionalidade.

Assim, a perspectiva de inserir o indivíduo preso numa ordem jurídica, reconhecendo-lhe o "status” de sujeito de direitos, direitos esses passíveis de proteção, representou, na tradição histórica brasileira, uma experiência absolutamente radical, sobretudo diante do tratamento desde sempre destinado à questão criminal e seu indissociável apego à questão social ${ }^{41}$.

\footnotetext{
${ }^{41}$ Adotando o conceito de R. Castel, pode-se definir a questão social como uma aporia fundamental sobre a qual uma sociedade experimenta o enigma de sua coesão e tenta conjurar o risco de sua fratura (1999:30). Vera Telles, na mesma perspectiva de Castel, aponta que a questão social não se reduz à pobreza, mas a essa aporia que põe em foco a disjunção entre a ordem legal que promete igualdade e a realidade das desigualdades e exclusões tramadas nas relações de poder e dominação (Telles, 2001: 115).
} 


\section{A JURISDiCIONALIZAÇÃO DA EXECUÇÃO DA PENA: UMA DISPUTA PELO ESTATUTO JURÍDICO DO PRESO}

Fernando Salla (1999), em seu trabalho sobre as prisões em São Paulo, faz uma importante ressalva, logo no seu início, para que o leitor possa compreender o peculiar processo que informou a introdução da pena de prisão no Brasil. Pondera ele que, diferentemente do que se dera na Europa, a prisão no Brasil não passou a ser utilizada com a concomitante extensão de direitos e garantias individuais preconizada pelas revoluções burguesas que marcaram a modernidade.

No Brasil dos séculos XVIII e XIX, a então nova racionalidade liberal criminal não prosperara em quaisquer termos, tendo sido a pena de prisão (com trabalho) inserida no país ao mesmo tempo em que persistiam as antigas espécies como a pena de morte, galés, açoites, banimento e desterro ${ }^{42}$ - penas já entendidas como cruéis do outro lado do Atlântico -, bem como conservando o sistema penal os traços característicos de sua atuação. Ou seja, continuou a moldar, em torno da questão criminal, uma extraordinária funcionalidade à conservação de uma estrutura social ancorada na escravidão, no latifúndio e na pobreza.

O Código Criminal da República, de 1890, traria em seu bojo um conteúdo de aparente inspiração liberal, num momento em que a escola penal positiva já influenciava grande parte do pensamento criminal na Europa. No entanto, como também observou Salla (1999), o ideário positivista, que encontrava no Brasil do período bastante aceitação entre os juristas, criminólogos e as elites, realizou-se no país não a partir da estrutura legal vigente, mas através de sua aplicação, mediante a existência de um projeto maior que contemplaria a existência de um complexo institucional (uma espécie de continuum carcerário na acepção de Foucault), destinado ao controle e ao confinamento da população pobre, negra e indisciplinada para o trabalho, desde a menoridade, tendo sido, o Estado de São Paulo, o que mais se aproximaria da realização desse projeto.

Desse modo, a possibilidade de conciliar inspirações aparentemente tão distintas quanto o estatuto liberal, de um lado, e o cientificismo e o determinismo penal, de outro,

\footnotetext{
42 Essas penas eram as previstas no Código Criminal do Império de 1830. Apenas em 1890, com o Código Criminal Republicano, as penas de morte, de açoites e das galés seriam abolidas, ficando a prisão celular eleita a principal modalidade de sanção.
} 
teria sido concretizada sem entraves pelos juristas e criminólogos da nova escola penal brasileira e pela elite política, uma vez que, como observou Alvarez (2003), o liberalismo penal “à brasileira” nunca esteve acompanhado de concepções democráticas ou minimamente igualitárias.

Não se fazia necessária, portanto, a estreita filiação às propostas radicalmente antigualitárias do médico baiano Nina Rodrigues ${ }^{43}$ para que a intervenção penal continuasse a operar tendo em vista, bem como acentuando, as abissais desigualdades sociais existentes, ou seja, se havia uma igualdade a ser perseguida no campo penal, essa era a igualdade, preconizada pela criminologia, que consistia em tratar desigualmente os desiguais (Alvarez, 2003: 240).

Nesse cenário, em que a questão social e a questão criminal se alinhavam sob um mesmo tratamento e destinação, não é difícil vislumbrar o quadro que as prisões apresentavam já no início do século XX, e, muito embora inscritas pelo ordenamento legal sob o signo do tratamento, expresso por um modelo progressivo de cumprimento da pena firmado no mérito e na recuperação, esse ideário positivista não encontraria as bases para sua efetivação, quer pela ausência de estabelecimentos que fisicamente comportassem sua execução ${ }^{44}$, quer pela tradição pátria de funcionamento das prisões, com o destaque ao aparato disciplinador expresso por castigos, torturas e favorecimentos, o que impedia que práticas de classificação, individualização e tratamento de criminosos pudessem sobreviver $^{45}$.

\footnotetext{
${ }^{43}$ Nina Rodrigues foi um dos mais radicais autores positivistas que o Brasil conheceu. Defendeu severamente as desigualdades entre as raças, a partir de pressupostos evolucionistas, chegando a propor um tratamento criminal diferenciado entre elas. A respeito, a tese de doutorado de Marisa Correa sobre a importância do pensamento de Nina Rodrigues na antropologia brasileira (Correa, 1982).

${ }^{44}$ Preconizava já o Código Criminal de 1890 a idéia de estágios da pena, adotando o modelo progressivo. O primeiro corresponderia à prisão celular, o segundo à penitenciária agrícola e o terceiro, ao livramento condicional. Não obstante o próprio primeiro estágio só ter se realizado na Penitenciária do Estado (em São Paulo), que possuía celas individuais, a inexistência de penitenciárias agrícolas inviabilizava os dois estágios seguintes, (Brito, 1926 e Moraes apud Salla, 1999). No Rio de Janeiro, contudo, os relatos de Candido Mendes apontam um número razoável de pedidos de livramento condicional concedidos, após a regulamentação desse instituto em 1924 (Koerner, s.d.).

${ }^{45}$ Fernando Salla (1999) desvenda como o estabelecimento concebido como modelar e o mais exemplar da América Latina no período, a Penitenciária do Estado de São Paulo, escondera, desde sua criação em 1922, por trás de um rigoroso projeto cientificista de tratamento e recuperação de delinqüentes, práticas recorrentes de tortura, violência e barbárie comuns aos demais estabelecimentos carcerários, acentuadas, contudo, por um código disciplinar severo e uma disseminada credibilidade popular, que silenciavam as atrocidades ocorridas intramuros.
} 
No que toca ao Poder Judiciário, mesmo após o advento da República, não haveria ainda que se falar em funções fiscalizatórias junto ao cárcere ou mesmo relativas ao acompanhamento do cumprimento pena. A atuação dos juízes criminais, assim, mantinhase adstrita à condenação, não desempenhando atividades propriamente jurisdicionais ou correcionais na prisão, estando a cargo do Poder Executivo e da administração dos estabelecimentos - que em sua maioria era exercida por delegados de polícia (Salla, 1999) - a gerência da massa dos indivíduos encarcerados.

Mesmo após a edição do Decreto 16.665 de 1924, regulamentando o instituto do livramento condicional e prevendo sua concessão por parte do “juiz da causa” - que remetia à figura juiz da condenação -, a atividade jurisdicional no cumprimento da pena não seria estendida, pelo menos não num primeiro momento. Isso porque o mesmo instrumento legal previa também a criação de um órgão com capacidade fiscalizatória na execução penal, o Conselho Penitenciário, vinculado à Secretaria de Justiça e composto por membros indicados e nomeados pelo Secretário, que, em tese, suprimiriam a atuação jurisdicional.

A criação de um órgão de atuação na questão penitenciária “independente, especializado e imparcial”, nos dizeres de seu inspirador, Candido Mendes, destinado, entre outras finalidades, a fornecer pareceres à concessão dos benefícios (Koerner, s.d.), consistiu numa inovação brasileira à época. Curiosamente, tais qualidades atribuídas em tese ao Conselho Penitenciário seriam justamente aquelas esperadas de um Poder Judiciário constituído a partir da clássica partilha de poderes dos Estados modernos.

No entanto, a idéia de um Poder Judiciário autônomo e independente nos moldes de Montesquieu permanecia bastante anacrônica no Brasil republicano. Koerner (1998) demonstra que, com a proclamação da República e de sua Constituição em 1894, nada seria alterado com relação à estrutura e ao funcionamento da justiça do Brasil imperial, ou seja, teria sido mantido e reforçado aquilo que o autor denominou como sistema de compromissos do coronelismo.

O controle e a ingerência na atuação dos juízes permaneceria garantido pela manutenção de uma forma de organização judiciária baseada na nomeação de magistrados pelo Executivo, leia-se, pelas elites locais dos Estados, juntamente a uma cautelosa distribuição de competências entre os magistrados profissionais e os juízes de paz, de modo que os interesses das oligarquias não sofressem qualquer tipo de ameaça. 
No Estado de São Paulo, Koerner descreve ainda o processo, vivenciado no período (fins do século XIX e início do XX), de valorização e independência promovido junto à instituição da polícia, a partir de uma reformulação na sua estrutura e nas suas atribuições, que resultaria numa ampliação de seus poderes. Por tal reestruturação, passou-se a estender sua competência a matérias e hipóteses antes restritas ao Judiciário, evidenciando, assim, uma predisposição do Estado em privilegiar a resolução dos conflitos por meios policiais em detrimento da ampliação dos meios judiciários à disposição da população (Koerner, 1998:241).

Em referido contexto não havia como se vislumbrar, desse modo, qualquer delineamento de um controle jurisdicional à execução da pena. Logo, é certo ainda que os instrumentos legais que dispunham sobre as competências dos juízes criminais sequer faziam menção à participação jurisdicional no cumprimento da pena. Mesmo com a Reforma Judiciária do Estado de São Paulo (lei no 1795 de 17/11/1921), que fora responsável por mudanças significativas na organização judiciária do Estado - como a criação de concurso público para ingresso na carreira de magistrado e a divisão das comarcas por entrâncias para fins de promoção - não se estabeleceria a previsão de qualquer hipótese de competência, ainda que concorrente, para fins de acompanhamento da execução da pena.

No entanto, isso não significa que não existisse qualquer atuação do Judiciário no cumprimento da pena, até porque a partir da regulamentação do livramento condicional, em 1924, sua concessão passara a depender de uma decisão judicial. O que significa, no entanto, é que inexistia qualquer prática que pudesse refletir as noções de devido processo legal, controle jurisdicional, direitos e garantias individuais dos presos, no âmbito da execução penal. Nesse sentido, a atuação do juiz constituía-se em meramente corroboradora da atividade administrativa e em um apoio burocrático e técnico-legal à mesma.

A figura de um juiz de execução, ou a idéia de uma execução jurisdicionalizada ou fiscalizada por um órgão externo à administração, origina-se exatamente nesse período na Europa. A Itália foi o primeiro país a prever a criação de um juiz especializado na execução penal, denominado juiz de vigilância, a partir do seu Código de Processo Penal de 1930 (Lyra, 1944). 
Ao mesmo tempo em que a jurisdicionalização no cumprimento da pena passou a ser prevista nos ordenamentos jurídicos, instaurou-se a polêmica de sua previsão, ocupando esse debate o centro das discussões que se travariam nos sucessivos Congressos Internacionais Penitenciários realizados a partir de 1931 (Lyra, 1944). O que mais uma vez demonstra que tal debate longe de estar detido a uma mera nova previsão técnica legal, constituía, antes de mais nada, uma zona de conflito a partir da qual o que estava em jogo, para além da figura do juiz da execução, era a noção do sujeito de direito, ou mais precisamente, a de direito subjetivo do sentenciado, decorrente e emergente da noção de Estado de direito e colidente com as consolidadas e discricionárias práticas de administração penitenciária.

Desse modo, se a questão passava a gerar impasses e polêmica é porque o que estava no centro mesmo do debate sobre a jurisdicionalização era qual estatuto jurídico poder-se-ia atribuir ao preso. No caso de atribuir-lhe o "status" de sujeito de direito na acepção liberal, sua inserção na ordem jurídica era inevitável, o que representava uma ruptura com o ideário positivista do criminoso portador de periculosidade imanente, a quem não se imputava culpa, mas também não se atribuía direitos.

Com essa nova formulação, o criminoso passaria a ser portador de direitos que não foram atingidos pela condenação, abalando, por conseqüência, toda a construção cientificista de periculosidade. Nesse sentido, a idéia de jurisdicionalização, ou ainda, as conseqüências teóricas e práticas que dela advieram, importaram em um forte abalo na ideologia do tratamento que até então se experimentava.

Essa pode ter sido a chave para os desdobramentos que levariam ao declínio do paradigma reabilitador da prisão e sua sobreposição pelo ressocializador, consagrado pelo marco da aprovação das Regras Mínimas das Nações Unidas para o Tratamento de Reclusos em 1955, pelas Nações Unidas. É certo que as discussões travadas pela criminologia que se desenvolvia no período ${ }^{46}$, sobretudo com relação às críticas que passavam a empreender às teorias positivistas, funcionalistas e ao sistema penal de um modo geral, contribuíram sobremaneira para que as concepções da pena como tratamento e da periculosidade entrassem em declínio. No entanto, o que aqui se destaca é que a construção jurídica responsável pela entrada em cena de um novo paradigma em torno da execução da pena, teria sido então o conceito da jurisdicionalização.

\footnotetext{
${ }^{46}$ A descrição sobre tais teorias e seus representantes já foi formulada no capítulo anterior.
} 
No Brasil, até o Código de Processo Penal de 1941, a questão receberia tratamento diferenciado entre os Estados, uma vez que a eles competia legislar sobre direito processual $^{47}$. Em 1938, já sob o Estado Novo, o decreto $n^{\circ} 9008$ de 24 de fevereiro previu, pela primeira vez no Estado de São Paulo, a existência de um juiz que se incumbiria da execução criminal cumulativamente à presidência do Tribunal do Júri. A matéria seria prevista em lei federal em 1941, com a entrada em vigor do Código de Processo Penal, que passaria a prever de maneira genérica a competência do juiz (não necessariamente especializado, podendo ser o da condenação ou do Tribunal do Júri) para executar a sentença condenatória, destacando que a ele caberia decidir sobre os incidentes na execução.

O debate sobre a jurisdicionalização, contudo, assim como todos os outros que envolveriam a questão carcerária, permaneceriam ao longo dos anos seguintes silenciados pelos poderes públicos que trataram de extrair ao máximo qualquer conteúdo político dessa questão, de modo a transfigurá-la em problema técnico (Adorno e Fisher,1987).

Durante os anos da ditadura militar, o contexto de exarcebadas violações de direitos humanos pelo Estado minaria ainda mais as já escassas possibilidades de um debate qualificado e de mudanças importantes a respeito das questões de segurança e justiça como um todo, resumindo o biônico Executivo à intensificação das medidas de repressão e contenção, garantidas ainda pelo desmonte das instituições de Justiça e dos instrumentos legais existentes para resguardá-las, ou seja, pela corrosão democrática.

No que toca à política penitenciária propriamente dita, empreendida no Estado de São Paulo, é certo que essa esteve resumida, ainda segundo Adorno e Fisher, a medidas de expansão física do sistema, sem a preocupação na promoção de ações que visassem qualquer outra finalidade à pena de prisão que não seu aspecto puramente repressivo. Nesse sentido, predominou uma atuação que contribuiu para a intensificação do controle sobre a massa carcerária privilegiada pela ação policial, gerenciando-a segundo padrões reconhecidamente não democráticos, onde predominam o uso da força e o da violência como estratégia de contenção (Adorno e Fisher, 1987: 59-60).

\footnotetext{
${ }^{47} \mathrm{O}$ entendimento de que a execução penal apresentaria um conteúdo apenas processual vigorou no país até 1984, quando a Lei de Execuções Penais - LEP - foi promulgada, apontando a conteúdos de direito também material à execução.
} 
Desse modo, a questão social e carcerária continuaram a se articular, prevalecendo em geral a arbitrariedade do poder público, a omissão do Judiciário, o distanciamento da sociedade civil e a ausência do debate à problematização do tema, pelo menos até o processo de transição democrática, que imprimiria alguns desvios a essa trajetória. 


\section{A CPI do Sistema Penitenciário, o novo Código Penal e a PRimeira lei DE ExeCuções Penais}

Uma política criminal orientada no sentido de proteger a sociedade terá de restringir a pena privativa de liberdade aos casos de reconhecida necessidade, como meio de impedir a ação criminógena cada vez maior do cárcere. (Exposição de Motivos do Código Penal de 1984, item 28)

\section{O PROCESSO DE INSTITUCIONALIZAÇÃO DO DEBATE SOBRE A QUESTÃO CARCERÁRIA (1975-1984)}

A CPI sobre o Sistema Penitenciário, como já mencionado, foi instalada em 1975 sob os auspícios de levantar os principais problemas e deficiências das prisões em caráter nacional e de propor, junto a um diagnóstico obtido, um conjunto de soluções ao Executivo acerca da questão carcerária.

As considerações e propostas apresentadas tiveram como identificador comum, como eixo axiomático, a perspectiva da reinserção social do condenado como finalidade precípua da prisão, algo que representou um giro nas concepções que informavam o discurso oficial até aquele momento. Para além de ter sido definida, por um de seus deputados, como o próprio problema posto pela Comissão, ou seja, o objeto de sua instalação - a promoção do homem encarcerado e a reeducação do presidiário (Diário do Congresso Nacional 04/06/1976, suplemento p. 89) -, é certo que o conteúdo dos depoimentos prestados por especialistas, e, sobretudo, por dirigentes de estabelecimentos prisionais e por representantes de Estado, eram unívocos quanto a tal finalidade.

Pode-se reconhecer, nesse momento, um verdadeiro deslocamento no discurso oficial sobre a prisão. Isso porque, embora o Brasil já tivesse experimentado com a nova escola penal e suas inspirações positivistas um discurso sobre a intervenção penal centrado no tratamento e na cura do criminoso, relativizando assim o conteúdo liberal (e retributivo) dos estatutos legais em vigor, não contemplava tal perspectiva o reconhecimento de direitos dos indivíduos presos com vistas a um processo de reintegração social. Ao contrário, pela tradição positivista, como observou Alvarez (2003), 
a insistente preocupação, por exemplo, com as péssimas condições apresentadas pelos cárceres, nada se relacionava a uma medida de dignidade e de direitos a que os presos seriam portadores, mas antes a empecilhos para a realização do ideário de um tratamento eficaz.

É verdade, contudo, que pela análise do teor dos debates realizados na CPI, pode-se notar que o discurso da recuperação não fora abandonado por completo, sendo que o conteúdo dos depoimentos prestados à Comissão acabam muitas vezes por refletir um certo hibridismo entre ideários positivistas calcados na biotipologia do criminoso e na sua recuperação e concepções humanizadoras embasadas, sobretudo nas Regras Mínimas das Nações Unidas e na perspectiva da ressocialização do preso. A heterogeneidade podia ser encontrada, inclusive, na fala de um mesmo depoente, refletindo uma zona de indiferenciação entre tais perspectivas.

Um interessante exemplo desse hibridismo foi o depoimento de Manoel Pedro Pimentel, então Secretário de Justiça de São Paulo, e responsável pela inauguração, ainda no regime militar, de uma política penitenciária de maior abertura tanto no sentido de promoção de diálogo com outros segmentos da sociedade como pelas difundidas idéias de implantação de um modelo de prisões abertas ${ }^{48}$.

Ao mesmo tempo em que o então Secretário defendia o uso da prisão de modo mais racional e menos intenso, bem como que a política estabelecida fosse norteada pelo atendimento a direitos individuais e sociais do preso, chegava a propor uma rigorosa classificação biotipológica do criminoso, e ainda a relatar técnicas pouco ortodoxas para o tratamento penal daqueles não afeitos à disciplina carcerária ${ }^{49}$.

No entanto, não obstante a presença de argumentos relacionados a uma determinação psicopatológica do crime, o deslocamento observado referiu-se nesse momento à predominância de uma orientação norteada pelo reconhecimento de direitos

\footnotetext{
${ }^{48}$ Manoel Pedro Pimentel, enquanto juiz do Tribunal de Alçada Criminal de São Paulo, foi uma figura importante para que o instituto da prisão-albergue fosse regulamentado pelo Tribunal de Justiça e se realizasse como uma experiência pioneira no Estado durante as décadas de 60 e 70.

${ }^{49}$ Relatou o Secretário à Comissão o seguinte episódio ilustrativo: Desde que o Instituto de Biotipologia Criminal adquiriu um aparelho chamado eletroencefalógrafo, resolvemos inúmeros problemas de agressividade com 2 pastilhas por dia: localizava-se no cérebro a alteração e dava-se o remédio. Houve o caso de um homem que viveu 16 anos antes de adquirirmos o aparelho em cela forte (...) Quando esse aparelho foi comprado, um dos primeiros a serem testados foi ele. Constatou-se o problema cerebral. Duas pastilhas por dia. Quinze dias depois ele trabalhava na administração do presídio e nunca mais teve problema, entrou em bom comportamento, foi posto em liberdade. (DCN, suplemento, p. 86)
} 
como condição para que se atingissem as finalidades da ressocialização e da reintegração do preso, ao invés da regeneração e da cura.

A definição desse pressuposto e sua incorporação pelo establishment deve ser considerada como um dos elementos responsáveis pela estabilidade da política criminal progressista que vigorou do pós-guerra até os anos 70 nos EUA e na Europa, num período que Garland (2005), como já mencionado, atribuiu a denominação de welfarismo penal.

No Brasil, além do fato da incorporação das concepções humanizadoras da pena pelo discurso oficial ter se dado tardiamente, num momento em que já estavam em crise em outros países, é certo que tais concepções não se constituíram e generalizaram-se a partir de dispositivos institucionais que as conformariam e integrariam, ainda nos dizeres de Garland, ao próprio funcionamento do estado de bem-estar social e sua política social democrata (2005:75).

O que equivale dizer que, sem as bases de um mundo social ancorado em políticas de integração, na regulação e na garantia de direitos sociais (a política do welfare state), também não seria possível experimentar o welfarismo penal em suas dimensões, o que pode explicar, não apenas a defasagem do discurso da ressocialização da prisão no Brasil, como a brevidade de sua existência.

É a partir de tal perspectiva que se deve compreender porque, assim como os promissores dispositivos da Constituição de 1988 não se efetivaram, as prescrições da Lei de Execução Penal de 1984 também nunca chegaram a sair do papel. É certo que o enfrentamento a uma determinada conjuntura internacional a partir dos 90 contribuiu para que referida lei tivesse ainda mais restritas suas condições de aplicabilidade, dado o anacronismo que passaram a simbolizar diante da ressignificação que a prisão experimentou a partir de então. Contudo, a inexistência de bases à universalização de direitos, quiçá os individuais, foi sem dúvida o principal óbice para que se realizassem os direitos e as garantias dos indivíduos encarcerados, como um momento subseqüente ao resgate político da questão carcerária. 
Oito anos depois de relatada a CPI do Sistema Penitenciário, eram promulgadas a Lei de Execução Penal e a reforma do Código Penal, em 1984. A história da reforma da legislação penal no Brasil foi, desde 1940, repleta de anteprojetos e projetos sancionados que nunca chegariam a entrar em vigor - revogações e novos projetos. Essa profusão de estudos e propostas sem desfecho, em muito se deveu aos próprios rumos da política brasileira no período, alternando um breve e tumultuoso período democrático entre duas ditaduras de naturezas distintas, o Estado Novo (1937-1945) e o regime militar (19641985).

Com relação à lei de execução penal, a primeira tentativa de criar um instrumento específico para a matéria data de 1933, quando uma comissão integrada pelos juristas Candido Mendes, Lemos Brito e Heitor Carrilho encarregou-se de elaborar o respectivo anteprojeto de lei, não sido posto em discussão com o advento do Estado Novo. Em 1953 e 1963 dois outros juristas, Oscar Stevenson e Roberto Lyra, apresentariam novos anteprojetos de Código de Execução Penal, firmando uma posição que se manteve a partir de então, segundo a qual cabia à União legislar sobre a matéria penitenciária. O último anteprojeto que antecedeu à promulgação da LEP em 1984 foi o texto elaborado pelo jurista e professor Benjamin Moraes Filho e revisto por uma Comissão de outros três juristas, em 1970 (Exposição de Motivos da LEP, 1983).

Também em 1963 foi elaborado um anteprojeto de Código Penal, que viria a ser sancionado em 1969, sem, contudo, jamais ter entrado em vigor. À frente da Comissão elaboradora, o mesmo jurista que foi responsável pelo texto do Código Penal em vigor desde 1940, Nelson Hungria. Sob a justificativa, por parte do governo federal, da necessidade de entrada simultânea em vigor de um novo Código de Processo Penal e uma Lei de Execução Penal, a vigência do Código Penal de 1969 foi sendo adiada até que, em 1978, o próprio Presidente da República encaminharia ao Congresso Nacional um projeto de lei revogando o texto aprovado em 1969, sob a justificativa de que o então vigente Código Penal de 1940, com as atualizações legislativas que havia sofrido ao longo dos anos, se tornara “mais atualizado do que o vacante” (Exposição de Motivos do Código Penal, 1983, item 4).

Já sob o último governo do regime militar, do então presidente João Batista Figueiredo, Ibrahim Abi-Ackel, agora como Ministro da Justiça, esteve novamente à frente do processo de reforma penal, não mais na figura parlamentar, mas na condição de 
responsável pela constituição das Comissões que elaborariam os textos referentes ao Código Penal e à Lei de Execução Penal, aprovados em 1984. É de se registrar que tais Comissões foram compostas por juristas e professores de orientação notadamente garantista, como Miguel Reale Junior, René Ariel Dotti, Sérgio Moraes Pitombo, entre outros.

Nesse sentido, não obstante já naquele momento o fenômeno do aumento da criminalidade, sobretudo nos grandes centros urbanos, provocasse pressões no sentido de um melhor aparelhamento do aparato repressivo, a tônica dessa reforma foi dada no sentido de um aprimoramento dos instrumentos jurídicos de contenção do crime, mas a partir de uma orientação que superasse a constância da medida repressiva como resposta básica do delito, a rejeição social dos apenados e seus reflexos no incremento da reincidência (Exposição de Motivos do Código Penal, 1984, item 5).

O conteúdo dessas leis consagrava, assim, novos rumos à política criminal brasileira que vinha até o momento regulamentada por estatutos inspirados no Estado fascista italiano (1922-1945), bem como visava atender a uma agenda de atualizações legais, sobretudo com relação às orientações internacionais referentes ao tratamento do recluso e às demandas sociais por garantias de direitos que um Estado democrático reclamava.

Ainda sob o clima de abertura política, os anseios por um Estado que restringisse ao mínimo direitos e garantias individuais foi o que deu o tom de referidas leis penais. Como se pela primeira vez no país, a idéia da preservação e garantia de liberdades e direitos civis a todos os indivíduos tivesse encontrado, no plano legal e oficial, alguma previsão.

Era expressão dessa aparente ampliação de garantias individuais um rol de medidas como o princípio da presunção de inocência, a irretroatividade da lei penal, a prisão apenas por decisão judicial, os limites da prisão temporária, a prescrição de penas, a proibição de prisão por dívidas e princípios como a individualização, a progressividade e a jurisdicionalização da execução, que, após a Constituição Federal de 1988, ganhariam ainda maior respaldo.

Inaugurava-se, assim, no plano legislativo e, portanto oficial, o discurso de uma política criminal que priorizasse um tipo de intervenção penal que encontraria na prisão seu último recurso, e a partir do menor tempo possível, reconhecendo-se e ressaltando-se, 
desse modo, os efeitos criminógenos do cárcere, segundo disposição expressa na Exposição de Motivos do Código Penal, item 61.

Para tanto, previa o Código um novo elenco de penas, introduzindo as espécies denominadas alternativas ou, na acepção que a lei adotou, restritivas de direitos, sendo a mais destacada delas a prestação de serviços à comunidade, em meio aberto. Estabeleceria a aplicação, ainda, de forma sistemática, do princípio da progressividade da pena a partir da previsão e regulamentação de três etapas de cumprimento da pena - regimes fechado, semi-aberto, aberto (prisão albergue), e o livramento condicional.

Com relação à idéia de que o novo Código teria adotado o princípio da culpabilidade para a aplicação da pena e se desvencilhado assim da tradição positivista, Fry e Carrara (1985) são críticos a essa visão, uma vez que, segundos eles, o princípio informador da periculosidade não teria sido eliminado, mas ao contrário, teria se mantido subjacente de modo a desnudar a aparente liberalidade dessa lei. A conclusão dos autores se faz, sobretudo levando em conta a existência de dispositivos postos à classificação de presos e verificação de mérito para a progressão de regime, como os exames criminológico e de personalidade realizados pelos recém-instituídos Centros de Observação Criminológica (sucessores do Instituto de Biotipologia Criminal) e pelas Comissões Técnicas de Classificação - CTC - a serem instaladas em cada estabelecimento penitenciário.

A perspectiva de Fry e Carrara pode ser relativizada, contudo, se levarmos em conta as exatas previsões e as dinâmicas de aplicação do Código anterior, de 1940. Primeiro, o critério da periculosidade que podia redundar na aplicação da prisão acrescida à medida de segurança - o denominado sistema duplo binário - era dedutível do tipo de crime cometido, privilegiando aqueles relacionados à indisciplina e à desordem social, como a vadiagem, a ociosidade, a prostituição, ou ainda a uma condição socialmente atribuída ao indivíduo como os “ébrios habituais” e os “toxicômanos”. Nesse sentido, eram evidentes os propósitos de controlar e confinar (não somente pela prisão, como também pelo manicômio) as camadas populares insubmissas, indóceis e indisciplinadas, em consonância ao grande projeto positivista de profilaxia e controle social para além da repressão ao crime. 
O novo Código, ao restringir o conceito expresso de periculosidade e a aplicação da medida de segurança tão-somente aos loucos criminosos $^{50}$, eliminou o mecanismo ostensivo de controle do antigo Código, centrando na pena de prisão a resposta penal por excelência e nas suas regras, aí sim, de conteúdo mais liberal, como a proporcionalidade, a temporalidade, e no princípio da culpabilidade, o substrato de sua aplicação.

É certo que os conteúdos positivistas não abandonaram por completo o novo Código, sendo os exames criminológico e de personalidade os instrumentos que conferiram a dimensão dessa permanência. No entanto, também aqui a orientação parece diferente do diploma anterior. A imprescindibilidade de sua realização passou a ser prevista para os crimes mais graves (apenados com reclusão), bem como a idéia de classificação de presos seria estabelecida levando em conta a gravidade do delito e a perspectiva da reincidência, e não os dispositivos de controle centrados em referência ao trabalho e a padrões de moralização da ordem pública.

Por outro lado, foi a partir dela (da classificação) e do seu princípio informador, a individualização da pena, que se operacionalizaram as mudanças axiológicas pelas quais o discurso da ressocialização se realizaria: a perspectiva de mitigação do uso da prisão, da valorização às alternativas penais, e, por fim, da progressividade da pena calcada na noção de merecimento atribuído por critérios não exclusivamente definidos pela disciplina carcerária.

É certo ainda que, a noção merecimento a que o preso deve se submeter para alcançar o regime progressivo não foi introduzida pela reforma de 1984, estando há muito presente no sistema, mas condicionada ao comportamento carcerário apresentado pelo preso e à sua adesão ou não a um determinado regime disciplinar. A aparente prevalência dos padrões de avaliação médica ou científica sobre os de segurança e disciplina que a reforma legal de 84 instituiu apenas reativou, assim, uma antiga tensão existente no universo da prisão entre esses dois saberes, na disputa por posições hegemônicas (Paixão, 1986; Salla, 1998).

\footnotetext{
${ }^{50}$ O Código Penal de 1984 passou a prever a aplicação da medida de segurança apenas àqueles declarados inimputáveis e semi-imputáveis a partir de um diagnóstico médico (embora não exclusivo), eliminando a situação híbrida que existia até o momento: a aplicação da medida de segurança cumulativamente à prisão para os presumidamente perigosos (descritos acima) e a aplicação da medida de segurança isoladamente para os inimputáveis.
} 
Desse modo, com o Código Penal e a LEP de 1984, deu-se em verdade mais um deslocamento de poderes no interior da prisão, com a instituição das CTC e dos laudos, do que uma intensificação de controle sobre o preso, controle esse que fora desde sempre pelos agentes encarregados da segurança e disciplina a partir dos tradicionais dispositivos disciplinares centrados em geral na violência e no arbítrio. Não por acaso, a reforma da lei de execução penal em 2003, que será estudada no próximo capítulo, apresentará como eixo central novamente a reformulação de tais aspectos, restabelecendo a supremacia dos dispositivos disciplinares no funcionamento da prisão ao extinguir os exames e as Comissões Técnicas que os realizavam.

É nesse sentido que a interpretação de Fry e Carrara (1985) de que a periculosidade teria sido a premissa lógica a fundamentar o Código de 1984, reativando os dispositivos do Código anterior e sofisticando-os, pode ser contestada em seu sentido maior, reconhecendo-se sim a permanência de conteúdos positivistas, no entanto a partir de lógicas completamente distintas, até porque as concepções deterministas e antropológicas em relação ao crime e ao criminoso já não eram mais operantes naquele momento, em que a própria idéia de disciplina e, portanto também de prisão, já se encontravam em mutação.

\section{A LEP E SUA NEGAÇÃO}

A primeira codificação da matéria referente à execução penal no país ocorreu através da LEP de 1984. Referida legislação, além de representar por si um deslocamento na forma de tratar a questão carcerária no país, trouxe também por seu conteúdo, implicações bastante práticas para o funcionamento e o cotidiano das prisões.

O deslocamento, como já apontado, referiu-se sobretudo à constituição do preso como sujeito de direitos através, essencialmente, do princípio da jurisdicionalização da execução da pena. De outro lado, eram também as finalidades atribuídas à prisão que se deslocavam nesse momento da retribuição e do tratamento para a ressocialização, instrumentalizando-se essa nova função a partir de outros dois princípios, apresentados agora reformuladamente: a individualização e a progressividade da pena.

A jurisdicionalização representaria a mediação pelo sistema de justiça nas relações e situações que caracterizam o cotidiano do cumprimento da pena. Assim, para além da 
intervenção técnica processual nos procedimentos, por exemplo, de livramento condicional, a nova disposição legal atribuía, durante toda a dinâmica da execução, a intervenção da justiça criminal, compreendendo ainda uma dimensão correcional à atuação dos juízes encarregados da execução penal.

Equivale dizer que, pela previsão que se inaugurava, a relação do preso com o Estado punitivo, simbolizado pela prisão, passava a ser de litígio, na medida em que podia o preso litigar, no cárcere, pelo exercício de seus direitos, valendo-se para tanto do devido processo legal.

Tal formulação, ou ainda a configuração que a jurisdicionalização proporciona, divide ainda hoje concepções distintas do poder de punir e dos limites do Estado na tarefa repressiva penal. A jurisdicionalização, como já dito, foi adotada a partir da década de 30 em boa parte dos países do Europa ocidental continental, subsistindo, entretanto, o modelo da administralização pura - o chamado hands off - na prática penitenciária anglo-saxã (EUA e Reino Unido) e na maioria dos países da América Latina.

A filiação por um ou outro modelo não deixa de representar, uma vez mais, a opção por incluir ou excluir o indivíduo preso da ordem jurídica, ou seja, define a parcela de sua exclusão e a medida (o limite) da intervenção penal que pode recair sobre o indivíduo.

A operacionalização e efetivação desse princípio, previsto na LEP de 1984, teria demandado um empenho conjunto entre os Poderes Executivo e Judiciário com vistas ao aparelhamento do sistema de justiça de execução - criação das varas de execução criminal, defensorias públicas, dotação de pessoal técnico e administrativo, além da própria reformulação da administração penitenciária. Para além desse empreendimento físico e operacional, a efetividade do princípio jurisdicionalizador exigiria ainda uma predisposição do juiz de execução, como principal ator designado pela legislação, a assumir a centralidade de tal processo.

Os poderes correcionais a ele atribuídos, por exemplo, exigiriam, pela própria previsão legal, a visita constante (ao menos mensal, dispôs a LEP) aos estabelecimentos prisionais, o que implicaria a participação direta do juiz no cumprimento da pena, exercendo ele uma função, sobretudo fiscalizatória, junto à administração nos presídios. Por outro lado, a atuação dos demais protagonistas que compõem o sistema de justiça, como o Ministério Público e a Defensoria Pública, também seria indispensável, sobretudo para que a idéia de devido processo legal e de ampla defesa se caracterizassem. 
No entanto, o que se verificou e hoje se verifica ainda mais intensamente é a inércia do Poder Judiciário e do Ministério Público na assunção de poderes correcionais, na medida em que a escassez de suas visitas aos estabelecimentos carcerários e de sua participação no cotidiano prisional transformam o conteúdo das previsões legais em letra morta. No mesmo sentido, a inexistência de Defensorias Públicas em grande parte dos Estados, bem como sua estrutura altamente deficitária naqueles em que se encontra constituída, dificultam ainda mais que a jurisdicionalização tenha condições mínimas de se realizar.

$* * * * * * * *$

Estabelecendo como principal finalidade da pena o estabelecimento de condições para a "harmônica integração social do condenado e do internado", a LEP previu ainda um elenco de direitos do preso, indo da integridade física e mental ao trabalho, passando pela educação, assistência médica e social.

Quanto ao trabalho, atribui-lhe a ambivalente condição de direito e obrigação, negando ao preso peremptoriamente a condição de trabalhador, condição essa que lhe garantiria o acesso aos direitos e aos mecanismos de proteção previstos na CLT e na Constituição Federal. Tal exclusão, além de permitir, por exemplo, que a remuneração do preso pudesse ser inferior ao salário mínimo, operou a absoluta exclusão do trabalho prisional da esfera de garantias, coberturas e proteções que o trabalho em geral possui, relegando-o a mais uma categoria dos domínios do contradireito, a partir da qual a prisão se inscreve. Desse modo, a mensagem da lei foi mais de permanência do que de rupturas ou mudanças “progressistas” no que toca à extensão de direitos, com exceção do fato de ter introduzido o instituto da remição do tempo de pena pelo tempo de trabalho ${ }^{51}$.

A limitação ao exercício de atividades com qualquer potencial criativo como o artesanato, a previsão de uma remuneração meramente simbólica ao trabalho prestado e a classificação de sua recusa como falta disciplinar grave foram algumas disposições que conformariam o trabalho carcerário à função de mais um dispositivo na engrenagem

\footnotetext{
${ }^{51}$ Estabeleceu a LEP o instituto da remição pelo qual a cada três dias de trabalho é computado um dia na pena. Estudos apontam a origem da remição no direito canônico, sendo certo que sua formulação mais contemporânea é encontrada em diversas legislações, inclusive no direito anglo-saxão (Alvim, 1991).
} 
disciplinar da prisão, como um elemento de docilização da força de trabalho e de correção moral (Foucault, 1998).

É possível afirmar, entretanto, que o simples fato de se ter inscrito o trabalho na prisão também como uma obrigação do Estado em fornecê-lo ao preso, e não apenas do preso em prestá-lo, juntamente às exigências de condições físicas e estruturais a que os estabelecimentos prisionais deveriam atender, em consonância às Regras Mínimas da ONU, compuseram um conjunto de determinações no sentido de conduzir a política penitenciária nacional a patamares de maior racionalidade, planejamento e humanização, com vistas à superação, assim, do cenário de horror que os cárceres brasileiros ostentavam.

A verdade, contudo, é que a reversão do quadro encenado pelo sistema prisional brasileiro, no qual a maioria da população cumpre pena em cadeias públicas ou presídios superlotados, sem as mínimas condições de habitabilidade e com parcas de sobrevivência, onde as moléstias contagiosas proliferam e os indivíduos amontoam-se em verdadeiros “depósitos”, era um projeto demais ambicioso para um estatuto legal, mesmo naquele momento histórico.

Com referência às bases para uma política que (re)inserisse socialmente o preso e o egresso, previu a LEP a criação de órgãos como os Conselhos da Comunidade e os Patronatos, os primeiros na perspectiva de participação e controle da sociedade junto ao cárcere, e o último mais voltado à reintegração do egresso.

Os Conselhos da Comunidade seriam vinculados e dependentes para sua instalação do Poder Judiciário, através de ato do juiz da Vara de Execuções Criminais de cada comarca onde houvesse presídios. A realidade de sua escassa instalação e ainda de sua inoperância em grande parte das comarcas, em muito pode ser creditada à própria postura do Judiciário, tanto na relutância em exercer seu papel correcional nas prisões - ou seja, atividades para além dos aspectos técnico-processuais - como pela sua tradicional resistência aos canais de participação e controle social.

Por outro lado, como será ponderado adiante, o esvaziamento do debate sobre as prisões e o afastamento dos movimentos sociais em torno do tema a partir dos 90, contribuiriam ainda mais para que a existência dos Conselhos da Comunidade 
permanecesse relegada a uma condição puramente simbólica nas escassas comarcas onde se constituiriam $^{52}$.

Com relação ao egresso, para além também da parca existência dos Patronatos, a ausência de uma política que articulasse os Poderes Executivos federal, estadual e municipal, na definição de estratégias e que contemplassem a efetiva inserção dessa população, conferiram a absoluta ineficácia aos dispositivos que contemplavam sua assistência.

Ao lado da previsão e atribuição expressa de um extenso rol de direitos aos presos, de exigências físicas e estruturais a que as penitenciárias deveriam atender e da criação de órgãos encarregados da política de ressocialização, a LEP adentrou o cotidiano de funcionamento das prisões, atribuindo, pela primeira vez na história dessa instituição no país, um tratamento legal à questão disciplinar.

Impor um tratamento legal à disciplina carcerária significou trazer para os marcos da legalidade, do devido processo e, em tese do controle judicial, a pedra fundamental do funcionamento da prisão. Através da extinção da cela forte, da regulamentação do procedimento disciplinar à aplicação de sanções previstas na lei, da previsão de condutas consideradas faltas graves e suas sanções e do controle jurisdicional sobre toda a dinâmica disciplinar, tanto pela correição aos presídios, como pela posterior apreciação dos processos disciplinares por faltas graves, a LEP penetrou o campo obscuro e central da existência prisional, introduzindo nesse espaço a previsão legal e a mediação do sistema de justiça.

Ao promover a entrada da lei num campo dominado até então pela norma, não obstante a insidiosa co-relação de dependência entre elas - afinal, a realização da lei e de seu ideário universal está assegurada pela existência da norma disciplinar, o lado obscuro das liberdades e garantias individuais na modernidade segundo Foucault (1997a) -,

52 O DEPEN, órgão do Ministério da Justiça responsável pela formulação e execução da política penitenciária nacional, não dispõe de informações precisas sobre o número e a forma de funcionamento dos Conselhos da Comunidade, em muito por ser um dado que diz respeito ao Poder Judiciário de cada Estado, o que não deixa de refletir, contudo, a falta de interação e de articulação entre tais Poderes em suas instâncias diversas, e, por conseguinte, a fragilidade de uma política penitenciária formulada e consolidada como tal. O que se verifica ainda é que tais Conselhos acabam por se constituir mais comumente em pequenas comarcas, nas quais o contato do juiz com a comunidade se realiza de modo mais estreito. Na cidade de São Paulo, por exemplo, que durante muitos anos abrigou a maior população carcerária do país, esse Conselho só foi ser instaurado (no plano formal) no ano de 2004, estando até o momento sem atuação devido à precariedade de sua implantação. 
atingiu-se diretamente as forças que representam a consolidada cultura prisional, os agentes encarregados da segurança e disciplina. Referidos atores receberiam, assim, o conjunto das regras trazidas pela nova legislação como uma ameaça direta ao exercício de seu já estabelecido poder, promovendo a principal ordem de resistências à aplicação da LEP e à efetivação de seus dispositivos.

Para além de tais resistências, teria sido, de modo geral, ingênuo supor que as disposições, os princípios e os direitos previstos pela LEP se efetivariam a ponto de refundar um outro sistema carcerário em alguns anos, o que não teria sido imaginado nem pelo mais empenhado reformador. No entanto, a criação de uma nova medida de referência e intervenção na questão carcerária, onde ao menos em tese os direitos poderiam ser reivindicados e a tortura não se naturalizasse e se impusesse como regra, teria sido um efeito esperado, se alguma condição de aplicabilidade a essa lei houvesse sido criada.

A LEP, consagrada à época como uma das leis mais "avançadas” por juristas e especialistas, permaneceu ao longo dos anos, contudo, como letra morta, inaplicável em praticamente todos seus princípios e disposições. O conformismo quanto à sua inaplicabilidade e a omissão do Estado em possibilitar tal aplicação - a ausência de estruturação das varas de execução em grande parte das comarcas pelo Judiciário, a não criação de defensorias públicas e a manutenção da estrutura física e da cultura organizacional dos presídios pelo Executivo, entre outros - possibilitaram que um perigoso círculo vicioso fosse mantido, no qual a não efetivação dos dispositivos legais serviria para intensificar a deslegitimação dos direitos desse público, resultando em desdobramentos que levariam à sua completa negação por amplos segmentos sociais.

A gradativa desmobilização das forças que antes polemizaram a questão carcerária permitiu ainda que antigos consensos fossem reatualizados, resumidos na expressão central de que os direitos humanos são privilégios de bandidos (Caldeira, 2003), conduzindo a uma onda conservadora sem precedentes, a partir da qual cada vez mais os direitos individuais passaram a ser recusados e a constituição da figura central para a existência societária, o sujeito de direitos, a esvaecer.

Sua inaplicabilidade, em praticamente todos os termos e previsões, refletiu mais uma vez o choque que representa uma medida que pretenda a universalização de direitos numa sociedade que não supera sua experiência histórica de negação e recusa a eles, 
sobretudo os individuais, num fenômeno que Teresa Caldeira denominou de democracia disjuntiva (2003).

Segundo a autora, no país, enquanto aos direitos sociais e políticos é atribuída relativa legitimidade (embora também ausente sua efetivação), os direitos civis em geral são, não apenas sistematicamente violados, como encontram na opinião pública e no próprio senso comum o eco para sua negação. Na base desse fenômeno, ainda nos dizeres de Caldeira, a peculiar relação com o corpo que a sociedade brasileira estabelece, como a especial tolerância à sua manipulação e intervenção - o que certamente permite compreender suas representações sobre punição e, sobretudo, a aceitação de seus excessos. Umbilicalmente ligados a essa relação, é certo, os aspectos informadores do próprio processo de formação social no país - ancorados no escravismo, na violência e na contínua subtração da política (Oliveira, 2000).

Alguns poucos anos após a entrada em vigor da LEP, os acontecimentos políticos que levariam ao cenário dos anos 90, com o aumento da criminalidade e da violência estatal, tanto pelo aparato repressivo da atuação policial e do sistema de justiça quanto pela legislação criminal, seriam arregimentados de modo a desacreditar os dispositivos penais de 1984 e a propugnar a urgência de sua reforma, justamente nos aspectos que lhe foram mais caracterizadores: a atribuição de direitos aos presos e o ideário ressocializador. 


\section{A POlítica de hUMANiZAÇÃo dAS PRISÕES EM SÃo PAUlO E SEU DESFECHO: A NEGAÇÃO DE DIREITOS}

\section{Os PRecedentes: A Gestão MAnuel Pedro Pimentel (1975-79)}

A política de segurança e justiça adotada durante os anos da ditadura militar refletiu, como não poderia deixar de ser, uma filosofia altamente repressiva ancorada na predominância da atividade policial através do uso intensificado (e ilegal) da força física, e no cerceamento dos direitos civis e da liberdade de expressão. Em termos mais gerais, referida centralidade do aparato policial trouxe a marca de uma "nova divisão social do trabalho” para essa área (Adorno e Fisher, 1987), que passou a comprometer, também nos dizeres dos autores a já frágil institucionalização da questão penitenciária.

No caso do Estado de São Paulo, que será aqui estudado, essa política esteve caracterizada pelo recrudescimento das medidas de vigilância e segurança nos presídios, expressamente dispostas pelas normas administrativas que as previram, em detrimento de quaisquer outras ações que visassem à garantia de direitos ou que imprimissem alguma política de reinserção ao cárcere (Adorno e Fisher, 1988).

Entretanto, ainda sob o regime militar, no governo de Paulo Egydio Martins (197579) delineou-se os contornos que acenariam a um primeiro deslocamento do paradigma até então vigente, através da política adotada pelo Secretário de Justiça, Manoel Pedro Pimentel. Referido Secretário personificou o paroxismo no qual muitas vezes a prisão e os discursos a ele referentes estão inseridos. Embora, como já relatado, tenha dado grande ênfase a aspectos positivistas no tratamento da questão criminal, sua administração fora responsável por ações que redirecionaram a política penitenciária da exclusiva esfera da repressão para a da recuperação, especialmente pelo reconhecimento (formal) de direitos e pela perspectiva da desprisionalização.

Pimentel promoveu ainda uma gestão calcada na maior abertura à sociedade civil, articulando canais de interlocução com diferentes segmentos sociais como intelectuais, juristas e técnicos, o que pôde ainda redundar, em alguma medida, numa maior politização da questão carcerária. 
Dois pontos foram marcantes em sua gestão e contribuiriam para o delineamento de novos paradigmas atribuídos às políticas penitenciárias: a reforma administrativa do sistema representada na criação da COESPE (a Coordenadoria Estadual dos Estabelecimentos Penitenciários) e o fortalecimento da política de desinternação progressiva simbolizada pelo instituto da prisão-albergue.

A COESPE foi criada em 1979 pelo Decreto n 13412, em substituição ao extinto DIPE - Departamento de Institutos Penais do Estado - órgão que contava com estrutura investigativa e repressora, própria do contexto em que a política de segurança e justiça da ditadura estava inscrita. A criação de tal Coordenadoria ocorreu na tentativa de, pela primeira vez na história prisional paulista, articular uma política que não estivesse ancorada exclusivamente no aparato repressivo, mas a partir de órgãos e diretrizes que garantissem outras finalidades à intervenção prisional, levando-se em conta os fins da ressocialização e os mecanismos da ciência da administração (Adorno e Fisher, 1987).

Pelo Decreto de criação da COESPE, previu-se a organização do sistema por setores e órgãos encarregados de uma política de individualização e reinserção do preso e do egresso. Quanto ao aspecto ressocializador, a criação da FUNAP - Fundação de Amparo ao Trabalhador Preso - dois anos antes, em 1977, refletiria, ainda, a centralidade atribuída ao trabalho para o processo de recuperação e reinserção do presos, segundo as concepções de Pimentel.

Com relação à filosofia desprisionalizadora, o especial empenho à efetiva implantação do sistema de casas do albergado para acolher os condenados em regime aberto foi uma marca pessoal da gestão do Secretário de Justiça de Paulo Egydio Martins. Em verdade, desde quando juiz no Tribunal de Alçada Criminal, Pimentel fora grande defensor do instituto da prisão-albergue, que vinha sendo aplicado no Estado desde 1965, através de provimentos expedidos justamente por este Tribunal.

A prisão-albergue consistia numa modalidade de prisão aberta na qual o condenado considerado sem periculosidade seria destinado a estabelecimentos denominados “casas do albergado" durante a noite e nos finais de semana, submetendo-se a um tratamento diferenciado com vistas à sua reinserção, através de palestras e atividades que visassem esse fim.

Tal modalidade de pena trazia a grande vantagem de prescindir do cárcere como resposta penal (num momento em que seus efeitos criminógenos já eram propagados) bem 
como não trazia os inconvenientes da prisão domiciliar, sempre associada à idéia de impunidade, razão pela qual foi medida de bastante consenso à época, sendo acolhida inclusive pela reforma do Código Penal em 1984.

Pimentel, como o grande idealizador do instituto no Brasil, conseguiria instalar, até 1978, 46 casas do albergado no interior no Estado, e sempre convocando à parceria nessa instalação aquelas que seriam as "forças vivas da comunidade” na sua acepção - as Igreja Católica e Evangélica, as federações espíritas, as lojas maçônicas - imprimindo, de tal modo, sua marca a esse instituto (Pimentel, 1978).

Não obstante seus esforços em propagar as benesses da prisão-albergue, os anos que se seguiram assistiram à completa decadência desse instituto. Entre as razões, além das mudanças pelas quais passaria o discurso penal, sobretudo no que diz respeito ao desencarceramento e a medidas mais liberalizantes que entrariam em profundo desuso e descrédito no país a partir dos 90, é verdade que já àquele tempo a prisão-albergue não deixava de soar um tanto arcaica diante das transformações sociais e econômicas que o país vivenciava.

Outras medidas alternativas à prisão como a prestação de serviços à comunidade, que vinham sendo adotadas por diversos países e pela legislação nacional que passaria a prevê-las em 1984, se mostravam, já àquele momento, mais adequadas, sobretudo nos centros urbanos, do que a detenção, ainda que em tempo não integral, em estabelecimentos geridos filantropicamente e orientados por princípios de convencimento moral à recuperação dos condenados, como a prisão-albergue.

De todo o modo, a gestão de Manoel Pedro Pimentel foi, tanto pela maior racionalidade impressa à organização do sistema penitenciário como pela perspectiva desprisionalizadora de suas propostas, de fundamental importância para a definição dos rumos que a política penitenciária paulista e nacional seguiriam a partir de então. Suas idéias e projetos inspiraram ainda a LEP e a reforma do Código Penal, tendo sido inclusive, como já apontado, convidado a relatá-las na CPI do sistema prisional de 1975 que propulsou tais reformas.

Sua gestão representou, no contexto da política penitenciária paulista, um passo importante no (breve) percurso de humanização da prisão e de ressocialização que se experimentaria nos anos subseqüentes. 


\section{As MEdidAs de hUMANIZAÇÃo DA GESTÃo JosÉ CARLOS DiAs E SUA OPOSIÇÃo (1983-1986)}

Coube ao Poder Executivo a mais difícil tarefa no que toca à implementação das reformas contidas na LEP, ou seja, a criação das condições para que os novos dispositivos passassem a operar no funcionamento da administração carcerária, e das medidas necessárias à sua sustentabilidade. Significa dizer que colocar em prática uma política de atribuição de direitos aos presos, de introdução de controle legal no cotidiano disciplinar, e ainda propiciar a operacionalização dos procedimentos de classificação e individualização da pena, demandariam uma reformulação mesmo da estrutura e da lógica de funcionamento das prisões, ameaçando, por óbvio, a subcultura e o núcleo de poder consolidado nesses estabelecimentos pelos agentes encarregados da segurança e da disciplina, responsáveis pelo "gerenciamento" da massa carcerária a que Adorno e Fisher (1987) se remetem.

Em 1982, Franco Montoro seria eleito democraticamente para o governo do Estado de São Paulo, na primeira eleição direta a esse cargo depois do golpe de 1964. Montoro nomeou, em meados de 1983, o advogado criminalista, defensor de presos políticos e militante de direitos humanos, José Carlos Dias, para a Pasta da Justiça. Como militante, membro da Comissão Justiça e Paz, esteve ele ainda entre aqueles que integraram o Grupo de Trabalho sobre a Questão Carcerária na década de 70 em São Paulo, já citado anteriormente.

Como secretário, José Carlos Dias antes mesmo da tarefa de colocar em prática os dispositivos da LEP (que ainda não havia sido sancionada quando do início de sua gestão), assumiu o compromisso de levar adiante uma verdadeira reformulação no sistema penitenciário paulista a partir de iniciativas que compuseram diferenciadamente sua política, que ficou conhecida como de humanização dos presídios.

Além da gama de ações que se referiam, em verdade, à efetivação de direitos individuais dos presos como assistência jurídica, ampliação de vagas, ou a intervenções visando à contenção de tensões no sistema como a implementação da visita íntima aos 
presos do sexo masculino ${ }^{53}$, José Carlos Dias foi de fato além, ao prever a criação de mecanismos capazes de conferir ao preso uma existência também política. Assim, a criação das Comissões de Solidariedade e a instalação de urnas nos presídios, medidas de maior impacto e polêmica, representaram a constituição de verdadeiros canais de representação e interlocução direta entre o preso, as autoridades e a sociedade em geral, sem as mediações e os cerceamentos do poder disciplinar.

As Comissões de Solidariedade, segundo as previsões do Secretário, seriam instaladas em cada presídio e compostas por representantes dos presos eleitos pelos próprios por voto direto e secreto, numa expressão clara de extensão dos princípios democráticos ao cárcere. As restrições quanto à elegibilidade referiam-se à participação anterior em atos cometidos com violência a presos ou a agentes penitenciários (Góes, 1991). Previu-se ainda a constituição de comissões de representantes também dos agentes penitenciários, pressupondo uma igualdade de posições às negociações e às reivindicações, estabelecendo a odiosa medida de eqüidade que teria insuflado ainda mais esses agentes (Fisher apud Góes, 1991).

A radicalidade das medidas propostas por José Carlos Dias consistiu essencialmente no fato de conferirem ao preso a possibilidade (explicitamente negada no cárcere) de fala, o direito à voz, numa espetacular subversão da existência prisional com poucos paralelos na história. Destacam-se aqui duas outras experiências, ocorridas em países e momentos históricos diferentes, que de algum modo podem se aproximar das medidas de humanização de Dias, ponderando-se, contudo, os sentidos, proporções e mecanismos diversos pelos quais operaram.

O primeiro caso foi relatado por Paixão (1988) e se referiu à criação da "Liga do Bem-Estar Coletivo” em 1916 numa penitenciária norte-americana denominada Sing Sing. Embora assemelhada em sua forma de constituição às Comissões de Solidariedade dos presídios paulistas, uma vez que era composta de representantes eleitos pelos próprios presos, os limites de atuação da Liga americana eram bem mais demarcados: referiam-se

\footnotetext{
${ }^{53}$ A visita íntima foi instituída e regulamentada no Estado de São Paulo em presídios masculinos desde 1982, por ato da Secretaria de Justiça. Com relação às mulheres presas, esse direito foi vetado até dezembro de 2001, quando a visita íntima às presas foi finalmente regulamentada pela Secretaria e implantada nos presídios femininos do Estado, a partir de intensa mobilização de segmentos da sociedade civil na realização de encontros, publicação de artigos e notas na imprensa, organizados através de um fórum de entidades denominado Grupo de Estudos e Trabalho Mulheres Encarceradas.
} 
ao arbitramento de conflitos entre presos, pareceres em infrações disciplinares e em conflitos de interesses com a administração (Paixão: 1988:26).

A Liga representou uma experiência isolada em um único presídio, não consistindo ainda em um canal de comunicação do preso com o mundo exterior, mas apenas de reivindicações intramuros, limitada ainda pelo modelo de sistema penitenciário norteamericano, absolutamente administralizado. Paixão nos dá conta ainda que a Liga do Bem Estar teve uma existência polêmica e breve, em razão das disputas internas das lideranças estabelecidas no presídio de Sing Sing, tendo sido extinta com a demissão de seu criador, o rico empresário liberal Thomas M. Osborne.

A outra experiência foi a do GIP - Groupe d'information sur les prisons, constituído em 1971 por diversos membros da intelectualidade francesa, entre eles Michel Foucault e Gilles Deleuze, na tentativa de conhecer e divulgar a realidade das prisões justamente a partir das vozes silenciadas de seus principais atores, os presos. Para tanto, contudo, partiria do próprio Grupo a iniciativa para a mobilização e a criação de mecanismos para que se coletassem os depoimentos desses protagonistas e todo esse saber sobre a prisão pudesse enfim ser difundido, e não o contrário, como nas ações de Dias, em que o Estado propiciara os meios para que tais vozes ecoassem da prisão à sociedade. Na experiência francesa, a coleta desses testemunhos se daria pela “conclamação” a uma inquirição entre os próprios presos dentro do cárcere para que pudessem, em liberdade, divulgar e replicar esse conhecimento (Foucault, 2003b), marginal e em oposição assim à atuação estatal.

Eis o trecho da "primeira inquirição" do GIP publicada no $J^{\prime}$ accuse, n ${ }^{0} 3$ de 15 de março de 1971:

O Grupo de Informação sobre a Prisão acaba de formular sua primeira inquirição. Não é uma inquirição de sociólogos. Trata de dar a palavra àqueles que têm uma experiência da prisão. Não porque eles precisem que os ajudemos a "tomar consciência”: a consciência da opressão está ali, perfeitamente clara, sabendo muito bem quem é o inimigo. Mas o sistema atual lhe recusa os meios de formular, de se organizar. Queremos quebrar o duplo isolamento no qual se encontram enclausurados os detentos: através de nossa inquirição queremos que eles possam se comunicar entre si, transmitir o que sabem e falar-se de prisão a prisão, de cela a cela. Queremos que eles se dirijam à 
população e que a população lhes fale. É preciso que essas experiências, essas revoltas isoladas se transformem em saber comum e em prática coordenada. (Foucault, 2003:4)

Quanto às Comissões de Solidariedade do Secretário Dias, é certo que a proposta de sua criação consistia na idéia de se estabelecer uma instância (legitimada institucionalmente) de representação direta do preso com a sociedade, com as entidades de direitos humanos e com autoridades como o juiz corregedor e o próprio Secretário, na formulação de suas reivindicações, denúncias e propostas.

Antes mesmo de serem instaladas, as Comissões já provocariam extrema polêmica e cerrada oposição por parte dos funcionários encarregados da segurança e disciplina, bem como de diretores dos estabelecimentos penitenciários. A pressão contra a execução de tais medidas foi intensa de modo tal a apenas uma Comissão ter sido de fato constituída: em 1984 seria eleita a “Comissão de Solidariedade dos presos da Penitenciária do Estado de São Paulo”, como única experiência no Estado (Góes, 1991).

As forças que foram mobilizadas contra a política humanizadora de Dias tiveram sua origem nesta casta do sistema penitenciário - os diretores e guardas dos presídios -, mas logo arregimentariam um segmento importante da imprensa, representado em especial pelo grupo "Estado" - os jornais O Estado de S. Paulo e Jornal da Tarde - que se tornariam os principais porta-vozes de oposição à gestão do Secretário Dias.

Referida frente de oposição atuou, sobretudo na criação de um cenário de instabilidade e terror nos presídios, alegadamente instalada após a gestão de Dias e tendo em vista suas iniciativas. Por outro lado, o ataque era ainda de caráter mais geral à política de segurança adotada pelo governo Montoro, numa insistente tentativa de associar o aumento da violência e da criminalidade à adoção de medidas de maior controle da atividade policial, de humanização das prisões e, enfim, à tentativa de se implantar uma política de direitos humanos na área de segurança pública (Caldeira, 2003).

A gestão de José Carlos Dias seria marcada, desse modo, por controvérsias, turbulências e rebeliões, apesar da autenticidade duvidosa de algumas delas. Segundo o estudo de Góes (1991), a primeira rebelião que se noticiou depois da entrada do Secretário Dias, em 28 de dezembro de 1983 na Penitenciária do Estado - PE -, teria sido inteiramente "fabricada" por tais agentes, com a clara finalidade de desestabilizar o 
Secretário e as anunciadas medidas de humanização. Ainda segundo levantamento da autora, a não identificação de lideranças, a ausência de reivindicações e negociações, seguida de espancamentos junto aos presos pelos próprios guardas da PE e transferências sem o conhecimento da justiça, constituíram fortes indícios desse arranjo.

$\mathrm{Na}$ divulgação das causas do suposto motim pela imprensa (sobretudo pelos veículos mencionados), alegou-se a existência de uma Organização entre os presos constituída com a finalidade de insuflar a massa carcerária a ações violentas (Góes, 1991:127), numa clara tentativa de impedir que a primeira Comissão de Solidariedade, prestes a ser criada, se constituísse.

Os anos que se seguiriam, durante a gestão de José Carlos Dias, seriam marcados ainda por uma seqüência importante de motins e rebeliões, merecendo destaque o fato de que o alto número de rebelados bem como o conteúdo das reivindicações em tais manifestações, pôde denotar, em alguma medida, um certo caráter coletivo em que as demandas estiveram revestidas.

A compreensão das razões desses levantes, justamente num momento em que o Estado acenava com políticas mais humanizadoras ao cárcere, é tarefa que demanda a definição do complexo universo em que tais questões estão inseridas. A expectativa trazida pela entrada em vigência dos dispositivos que conferiam a extensão de direitos pela nova legislação penal e pelas medidas anunciadas pela gestão Dias certamente chocou-se com a realidade que se prolongava nos estabelecimentos carcerários, sobretudo naqueles que pela sua natureza ou estrutura não haveriam como ser atingidos por essa política ${ }^{54}$.

Permeando ainda todo o período, o próprio clima de abertura política e a postura do governo estadual, favorável à democratização da questão carcerária, podem ter contribuído para que as reivindicações pela concretização de direitos se intensificassem, valendo-se os encarcerados, contudo, dos canais tradicionalmente existentes, canais obviamente não propriamente democráticos.

\footnotetext{
${ }^{54}$ Um exemplo importante desse tipo de estabelecimento é a Casa de Detenção da Capital, local que, além de abrigar um número importante de presos não condenados e, portanto, não contemplados por uma série de direitos previstos na LEP, também apresentava um certo hibridismo na sua estrutura, o que não lhe conferia uma exata inserção nas políticas propriamente penitenciárias como as medidas humanizadoras já mencionadas. A Penitenciária do Estado, única a ter instalado uma Comissão de Solidariedade, não vivenciaria, de outro lado, qualquer outra rebelião no período, depois daquela noticiada logo no início da gestão de Dias em 28/12/1983, sendo certo ainda que apresentou, também no período, redução nos casos de violência e nas tensões internas, segundo levantamento da própria Secretaria (Góes, 1991).
} 
Mais do que descrever o desenrolar dessa política e seu desfecho, o que interessa aqui reter é a ordem de resistências e a natureza da oposição e dos ataques desferidos contra referida política, ou ainda contra uma certa orientação que ela e as novas leis penais, recentemente aprovadas, eram portadoras.

Para que se compreenda a dimensão do movimento de oposição que se articulou contra tal política, e que resultou na saída de José Carlos Dias da Secretaria da Justiça e na subseqüente adoção do "pacote de segurança ${ }^{55 "}$ e das medidas repressivas de caráter conservador pelos governos subseqüentes, autênticos representantes da "linha dura" em matéria de segurança e direitos humanos, é necessário que se separe esse movimento em duas frentes.

De um lado e num momento antecedente, as forças de resistência nos presídios que se ressentiram logo após a posse do Secretário, e que propulsionaram esse processo, representadas pelos agentes e diretores penitenciários. Referidos atores, por terem sob o estrito controle a própria dinâmica da organização das instituições carcerárias, detinham, como ainda hoje detêm, de modo geral, os mecanismos hábeis à manipulação da opinião pública e, enfim, de produção da realidade.

Na outra frente, tem-se outra natureza de ações/reações advindas de diferentes segmentos: da mídia, dos políticos de partidos oposicionistas e mesmo correligionários identificados à "linha dura” e da própria sociedade com suas representações sobre o crime, o criminoso e a prisão.

Com relação à primeira ordem de manifestações, oriundas dos encarregados pela disciplina carcerária, não obstante as peculiaridades do processo vivenciado na gestão de José Carlos Dias, em verdade elas acabam por remeter à tensão constitutiva e ambivalente entre a disciplina e o direito.

Como já apontado no capítulo precedente, o processo de ascensão das disciplinas, descrito por Foucault, desenvolveu-se como o "outro braço” do mundo liberal e do quadro jurídico de extensão formal de direitos. Ou seja, foi o campo “miúdo e cotidiano” da

\footnotetext{
${ }^{55} \mathrm{O}$ "pacote de segurança” composto por “duras” medidas no enfrentamento à violência foi lançado pelo candidato ao governo do Estado ainda na gestão Montoro, Orestes Quércia, que era, em verdade, vice do próprio Montoro. Sua vitória ao governo, além de refletir as configurações políticas e os arranjos internos pelos quais o PMDB passava que levariam ao desmembramento do partido e à formação do PSDB, não puderam deixar de representar, ainda, a ascensão de uma determinada ideologia quanto à segurança pública, que chegaria ao seu ápice no Massacre do Carandiru, em 1992.
} 
norma e das disciplinas que garantiu a existência do domínio da lei e do ideário jurídico burguês da igualdade formal nas sociedades modernas. Assim, embora antitéticos, lei e norma se articularam de modo a possibilitarem sua mútua existência.

Entretanto, ambos sempre delimitaram domínios de atuação distintos a partir dos quais seus dispositivos incidiram. As prisões, espaços disciplinares por excelência, sempre foram assim o locus onde a lógica assimétrica é a medida de (des)qualificação dos indivíduos, levando o controle hierárquico às últimas conseqüências. Não por acaso, Foucault define as disciplinas como um contradireito, na medida em que efetuam a suspensão nunca total, mas nunca anulada, do direito (Foucault, 1997a:184).

Ao ingressar com as regras do contrato no ambiente tomado pelo contradireito e ao se tentar fazer presente nas prisões como referencial simbólico a partir do qual é possível se construir o imaginário igualitário (Telles, 2001), o Estado, representado na política de humanização do governo Montoro, tentou realizar uma equação impossível ao subverter a essência mesma e a gênese dessas instituições e a lógica de seu funcionamento. Se na experiência histórica brasileira em geral, esse imaginário igualitário nunca constituiu medida à realização da justiça social, diante de uma formação social marcada e comprometida pelo escravismo e por uma cultura política calcada no clientelismo e no paternalismo, pouco crível seria sua realização no espaço exemplar das disciplinas, do arbítrio e, sobretudo da violência, que a prisão perpetua.

Nessa perspectiva, a ordem de resistências advindas do carcereiro, a figura simbólica que é o guardião de tais estabelecimentos, foi nada mais que a ordem natural dos acontecimentos, mas a força de sua mobilização e o impacto de suas ações só foi possível ao encontrar na opinião pública acolhida excepcional e, na própria heterogeneidade interna do governo, sua fragilidade.

Como demonstraram os estudos de Caldeira (2003), as representações da população nos grandes centros acerca do crime e dos criminosos remetem, via de regra, a estereótipos recorrentes na caracterização desses últimos, recaindo sobre eles a figura do bode expiatório, que, personificando o mal, oferece o referencial para a autoconstrução que a população acaba fazendo de si: honesta e de bem. Na esteira dessa simplória operação maniqueísta, os demais atores, a mídia, os políticos conservadores e aqueles que em geral “atacam a idéia de direitos humanos”, encontram solo fértil para explorar ainda mais o ideário punitivo em que a representação máxima é a pena de morte ou o extermínio, sem 
mediações de um mundo ancorado no direito. A violência policial, como mais um exemplo do arbítrio que se instala no estado do não direito, encontra assim respaldo na aceitação ingênua da própria sociedade, que repudia sistematicamente as pontuais experiências políticas que procuraram erradicá-la.

Um episódio que contribuiu sobremaneira para o desfecho da política de humanização das prisões do governo Montoro veio ironicamente do segmento que em tese mais deveria apoiar as medidas de Dias: o Judiciário. Erigido como a principal figura à garantia de direitos do preso e à fiscalização da execução pela nova legislação penal que entrava em vigor, era razoável esperar que o juiz da execução fosse o principal apoiador e incentivador de uma política que fortalecesse a figura do sujeito de direito no cárcere e as garantias constitucionais.

Os acontecimentos que se seguiram, contudo, puderam demonstrar o quanto a missão colocada pela LEP ao Judiciário estaria ainda muito distante de ser cumprida. Mais do que carências materiais à estruturação do princípio da jurisdicionalização, é no âmbito das mentalidades que residia e reside a grande ordem de impedimentos à realização dos dispositivos legais e constitucionais em matéria penal e sobretudo penitenciária.

Tão logo se instalou a Comissão de Solidariedade na Penitenciária do Estado e promoveu-se um debate televisionado pela RTV Cultura entre o Secretário e presos membros dessa Comissão em igualdade de posições ${ }^{56}$, algumas semanas depois o juiz corregedor dos presídios da Capital, Haroldo Pinto da Luz Sobrinho, protagonizaria um dos episódios mais insólitos na história das prisões no Brasil, ao estabelecer uma sorte de denúncias nunca comprovadas sobre a existência, naquele presídio, de uma Organização criminosa denominada “Serpentes Negras”.

Sua denúncia seria formalizada pelo envio, aos meios de comunicação, de uma carta de conteúdo alarmante, em que apontava a existência de matadores que estariam ascendendo sobre a massa carcerária para incitá-la ao cometimento de crimes,

\footnotetext{
${ }^{56}$ Documentário Para que serve uma prisão, produzido em maio de 1984 para o programa Debates da Rádio e Televisão Cultura, dirigido por Julio Lerner (Pinheiro e Braun, 1986).
} 
apresentando como solução ainda para erradicar tal Organização a reversão da política adotada e o restabelecimento de "posições mais duras" no trato da questão carcerária (Góes, 1991).

A existência dos “Serpentes Negras” ou de qualquer outra organização criminosa que agisse nos presídios paulistas naquele período jamais foi comprovada, mas os efeitos desestabilizadores de sua denúncia foram sentidos durante praticamente todo o período restante da gestão de Dias. Os meios de comunicação, sobretudo os já citados, deram ampla cobertura e alarde ao fato, posicionando-se contundentemente não apenas por sua veracidade, mas na associação de sua existência às medidas da política de humanização nas prisões.

Em todas as sindicâncias instaladas, nos três poderes, houve unanimidade em não comprovar a existência dos “Serpentes Negras” (Góes, 1991). Nem mesmo os depoimentos de funcionários do sistema opositores à gestão Dias, colhidos no Legislativo pela Comissão Especial de Inquérito sobre Segurança Pública, atestaram a veracidade das denúncias do juiz corregedor (CEI Assembléia Legislativa, 1984).

O procedimento instaurado na Corregedoria de Justiça para apuração dos fatos, no mesmo sentido, concluiu por não atestar a existência da organização criminosa, não tendo se procedido, contudo, a qualquer medida no sentido de punir o juiz Haroldo pelo episódio encenado.

Ironicamente ou não, a questão das organizações criminosas nos cárceres brasileiros, sobretudo em São Paulo, estaria umbilicalmente implicada nas políticas penitenciárias que passariam a ser empreendidas, inclusive a nível nacional, a partir dos anos 90. A gênese de tais organizações, que efetivamente se constituiriam no Estado de São Paulo a partir desta década, contudo, assim como o pioneiro Comando Vermelho no Rio de Janeiro, pode ser encontrada em regimes de acentuado arbítrio e violência característicos de determinados estabelecimentos prisionais e de precisos momentos históricos em que tais organizações foram concebidas.

Assim como o presídio Cândido Mendes de Ilha Grande/RJ na década de 70, o Anexo da Casa de Custódia de Taubaté/SP serviu de cenário ao surgimento do PCC - o Primeiro Comando da Capital - a organização criminosa que ao longo dos anos demonstraria uma capacidade de mobilização à violência e a ações criminosas sem 
precedentes, dentro e fora das cadeias paulistas, fortalecendo-se na esteira da ausência ou da insidiosa presença do Estado nesses estabelecimentos.

O desfecho da política penitenciária contemporânea, em que o único sinal visível tem sido a barbárie, revela-se sintomático de um tempo e de um espaço marcados pela ausência de política, na exata acepção de Ranciére e, mais ainda, por seu completo avesso, restando como nunca, a ordem da dominação e a desordem da revolta (1996:27). Um desfecho radical e diametralmente oposto às promessas democráticas a que toda a ordem social brasileira assistira no final da década de 80 , restando assim a indagação sobre o que teria ou não acontecido nos anos que sucederam à redemocratização para esse desvio tão intenso de trajetória. 


\section{CAPÍtUlo III}

\section{O DECLÍNIO DO IDEAL RESSOCIALIZADOR E A POLÍTICA CRIMINAL DE EXCEÇÃO A PARTIR DOS 90}

SUMÁRIO: $O$ contexto; 1 . A legislação criminal de urgência e o encarceramento massivo; • A lei dos crimes hediondos e o seqüestro da política; 2. O papel do Judiciário na política criminal de exceção.

Os maiores perigos do crime nas sociedades modernas não vêm dos próprios crimes, mas do fato de que a luta contra eles pode levar as sociedades a governos totalitários.

(Nils Christie, A indústria de controle do crime,1998: 5).

O contexto

Se o início dos anos 80 foi marcado pela emergência do restabelecimento da ordem democrática, trazendo consigo a promessa de universalização dos direitos fundamentais e a ampliação da cidadania, os anos 90 assinalaram a frustração das promessas não realizadas.

Não obstante a promulgação do texto constitucional em 1988 e seu teor indicarem se tratar, pela primeira vez na história do país, de uma “Constituição cidadã”, os anos que de imediato se seguiram não confirmaram as expectativas de reconhecimento de direitos e cidadania para os amplos e tradicionalmente excluídos segmentos da sociedade brasileira, em razão da inaplicabilidade de grande parte de suas disposições, o que teria inviabilizado ainda mais as possibilidades da conquista de um espaço público, nos termos de Hannah Arendt (2001).

Para além da já frágil estrutura institucional que sustentasse, por exemplo, a extensão da previsão e cobertura dos direitos sociais, ou seja, do agora ampliado sistema de proteção 
social $^{56}$, um fator que fortemente desfavoreceu a efetivação desses direitos foi o desmonte dos serviços públicos representado sobretudo pela política de privatização do público levada a cabo no decorrer da década de 90, que, como Francisco Oliveira demonstra, foi além do processo de privatização das empresas estatais para alcançar a produção de uma nova subjetividade que prega a desnecessidade do público (2000).

Mas foi sobretudo a prevalência de uma política econômica calcada nos ditames do mercado, em que o alcance de metas fiscais conseguidas a partir altos juros e absoluta compressão orçamentária em nome de vultuosos “superávits primários”, pôde redesenhar, não obstante as previsões da Constituição de 1988, o papel do Estado na distribuição da riqueza social e, assim, do tratamento da questão social no país, coibindo ainda mais fortemente as possibilidades de realização dos direitos de cidadania a setores mais amplos da sociedade.

Se, com relação aos direitos sociais, o conservadorismo das políticas econômicas neoliberais deu o tom da impossibilidade de sua realização, com relação aos direitos individuais apenas se vivenciou o outro lado do jogo neoliberal. Como acentuou Garland (2005), a "liberdade" dos investidores (e das classes mais favorecidas) e sua predisposição a correr riscos no mundo dos mercados financeiros, só podem ocorrer na medida de um disciplinamento e um controle mais acirrado às frações da população que ficaram de fora da partilha da riqueza social.

Esse verdadeiro processo de cisão social, que no caso brasileiro nada mais consistiu do que no aprofundamento de divisões já existentes, teve a novidade de promover um novo ethos, o que foi denominado por Boaventura Souza Santos como apartheid social, que se manifestaria com especial ênfase nos grandes centros, pela contínua produção de zonas de permanente exclusão, zonas selvagens, em contraponto àquelas onde o mito fundador da modernidade ainda regeria, as zonas civilizadas (2000).

Nesse cenário, a violência acaba por desempenhar um papel de relevância ímpar. Não é por acaso que os autores são uníssonos em reconhecer o aumento do fenômeno da violência,

\footnotetext{
56 A CF de 88 concebeu um sistema de seguridade social incorporando, para além do regime de previdência social que condicionava sua prestação à condição do vínculo empregatício, a assistência social e a saúde, acenando com a promessa de incorporar à cidadania uma maioria que, à margem do mercado formal de trabalho, sempre esteve fora de qualquer mecanismo de proteção social (Telles, 2001:144).
} 
sobretudo nos grandes centros, justamente a partir do período compreendido pela redemocratização (Adorno, 1996; Caldeira, 2003).

O que se identificou foi não apenas a persistência como o agravamento das violações de direitos humanos, não obstante a maior politização e debate acerca da segurança pública e a mobilização de organizações que no período iniciaram um maior monitoramento das atividades repressivas. No entanto, o quadro dessas violações apresentou-se: na falta de controle por parte do Estado com relação ao seu próprio aparato repressivo, que, embora ineficaz à coibição das formas emergentes de criminalidade como as organizações criminosas, teve intensificado o uso ilegal e abusivo da força, nas execuções sumárias e na violência policial que escalaram após a redemocratização; na manutenção das práticas repudiadas no plano legal como a tortura nos cárceres; no incremento do número de homicídios nas periferias dos grandes centros, locais preferenciais não só para a violência policial como para a concretização da barbárie que faz jus a idéia de um espaço do não direito: linchamentos, chacinas, resolução violenta de conflitos interpessoais (Adorno,1996), tudo isso à revelia de um Estado incapaz de oferecer segurança, justiça e o acesso a direitos fundamentais.

Nesse contexto, a promessa da garantia e universalização de direitos individuais, que não apenas a CF de 88 como os instrumentos legais de 1984 e todo o processo de abertura política preconizaram, revelou-se anacrônica e irrealizável.

Há que se reconhecer ainda, à compreensão desse aparente paroxismo (o incremento da violência num momento de restabelecimento democrático), as incompletudes do sistema de justiça penal que prolonga sua crise e sua incapacidade em distribuir justiça, punindo, mas preservando direitos (Adorno, 1996). É preciso considerar, ainda, que é no domínio mesmo da própria sociedade e do senso comum que se encontram a persistente negação do reconhecimento de direitos individuais de cidadania e a autorização das contínuas violações pelo Estado (Caldeira, 2003) e que esses dilemas marcam a manutenção de um autoritarismo social (Adorno, 1996:172), indiscutivelmente associado aos processos sociais que estiveram na base da formação da sociedade brasileira.

Desempenha ainda a violência uma especial funcionalidade à manutenção da nova ordem em um mundo social reconfigurado, revelando-se com especial destaque no cenário 
brasileiro contemporâneo. Como argumenta Paoli (s.d.) em recente estudo a violência opera pela manutenção da insegurança, cuja forma institucional de controle repressivo se confunde com a própria transgressão, agressividade e discriminação presente em todos os níveis cotidianos da cidade.

No plano da formulação das políticas públicas de repressão ao delito, que são o objeto de análise do presente trabalho, o que se passou a assistir a partir dos 90 foi, sobretudo no que diz respeito à questão carcerária, a perda do conteúdo polemizável e político que o período anterior havia despertado, tomando lugar um certo consenso ${ }^{57}$ conservador na linha dos movimentos que já vigoravam desde a década anterior, especialmente nos EUA de Reagan e na Inglaterra de Tatchter, e que inspiraram as correntes criminologias contemporâneas que Garland (2005) atribuiu de antimodernas, como disposto no capítulo I.

O que se verificará a partir de então é o desmonte de um recém-construído arcabouço legal em torno das garantias individuais em especial no que se refere à figura do acusado e do condenado. Sempre em nome de urgências declaradas em razão do risco à paz e à segurança de uma população honesta e ordeira ${ }^{58}$ - as novas práticas, estatutos legais e discursos irão tomar lugar da referência democrática da atribuição de direitos e garantias, erodindo pouco a pouco sua principal figura, o sujeito de direitos.

Nessa perspectiva, num contexto que extravasa o campo penal, é preciso, para a compreensão das forças e das categorias operantes na atualidade, um esforço de análise que, nos dizeres de Telles (s.d.) promova um deslocamento da crítica, do terreno da afirmação do espaço público democrático e dos direitos em sua vocação universalizante que compunham um espaço conceitual, uma determinada linguagem e um jogo de referências no qual a modernidade era tributária, para outras noções e espaços conceituais que irão comportar a mais recente contemporaneidade.

\footnotetext{
${ }^{57}$ Emprega-se o termo consenso aqui em um duplo significado: em oposição à categoria do dissenso definida por J. Rancière, discutida no capítulo anterior, e para demonstrar o ponto de convergência entre os discursos e as práticas de políticos de direita e de esquerda, no sentido de um endurecimento das medidas repressivas à margem da garantia de direitos. Referida unanimidade entre políticos de segmentos distintos estará presente na aprovação da legislação criminal nas décadas de 90 e 2000 e nos planos de governo dos candidatos a mandatos no Executivo e Legislativo.

${ }^{58}$ A retórica impressa por esses termos poderá ser encontrada nos discursos dos políticos, nas discussões do Parlamento e especialmente nas decisões judiciais condenatórias a partir de então.
} 
Como se verá, o momento político de profunda inflexão democrática representado pelos episódios que compuseram o contexto que levaria à vitória de Fernando Collor na eleição presidencial em 1989, serão centrais para os marcos simbólicos dessa derrogação de direitos e para a inauguração de uma política criminal que passou a se caracterizar pela (permanente) exceção.

\section{A LEGISLAÇÃo CRIMINAL DE URGÊNCIA E O ENCARCERAMENTO MASSIVO}

Como a decisão de declarar uma guerra, a decisão de infligir castigos cruéis ou ampliar as faculdades policiais é um exemplo de forma soberana da ação estatal. Não é necessária a cooperação, nem a negociação, nem se questionar se pode ou não funcionar. Essas medidas são atos soberanos dos quais se pode esperar que suscitem um amplo apoio popular e que gerem pouco em termos e oposição política organizada.

(David Garland, La Cultura Del control, 2005: 227)

Menos de um ano após a promulgação da Constituição Federal de 1988, o aumento da violência já era tratado no Congresso Nacional sob a exclusiva abordagem da derrogação de direitos dos acusados e presos e da intensificação do uso da prisão. Assim, no curso de pouquíssimos anos, a crença que inspirara a reforma do Código Penal e a Lei de Execução Penal no fim dos 70 e início dos 80, no sentido de que prisão não deveria ser a resposta principal ao delito e que seus efeitos criminógenos eram um mal maior que deveria ser evitado, esvaeceu-se e foi sobreposta por seu completo avesso.

Ao invés de debates, comissões formadas por especialistas e parlamentares para promover a discussão de medidas a serem adotadas ao tratamento da questão da violência, assistiu-se a uma onda de sucessivos projetos de lei ${ }^{59}$ interpostos em regime de urgência, que se apresentavam como a solução ao problema do delito a partir de um conjunto de proposições de caráter puramente repressivo e conservador, privilegiando o uso exarcebado da prisão e

\footnotetext{
${ }^{59}$ Franco, em seu trabalho sobre os crimes hediondos, apresenta um inventário dos projetos apresentados no período (2000: 87-89).
} 
atribuindo ao repertório legislativo de 84, de cunho "liberal”, a responsabilidade pelo aumento da criminalidade.

Seus conteúdos versavam sobre a supressão automática de direitos e garantias dos acusados, a restrição da margem decisória dos juízes com relação a determinados crimes e, sobretudo, o incremento de penas e a vedação de direitos e benefícios na esfera da execução da pena. Todos eles mobilizavam a categoria "crime hediondo" para se referirem a diferentes delitos que, em cada projeto, se pretendia alcançar.

A inexistência de definição pelo ordenamento jurídico (ainda hoje persistente) acerca do que seria crime hediondo abriria, desse modo, margem para seu emprego indiscriminado e a partir de referências particularíssimas, o que resultaria na manipulação ainda mais ostensiva da política criminal segundo interesses segmentados e de ocasião.

O primeiro projeto sobre a matéria foi apresentado pelo Executivo em setembro de 1989. Elaborado pelo Conselho Nacional de Política Criminal e Penitenciária, foi o único a conter uma definição (ainda que genérica - todo o crime cometido com violência à pessoa) sobre o que viria a ser crime hediondo ${ }^{60}$. Os diversos substitutivos que o seguiram, bem como aquele que seria aprovado como a Lei dos Crimes Hediondos - Lei 8072/90), não se prestariam a qualquer forma de definição sobre a natureza hedionda do delito, limitando-se a arrolar os crimes que, a partir daquele momento, taxar-se-ia de hediondos.

Na verdade, inexistia a figura do crime hediondo no ordenamento jurídico nacional, até a disposição constitucional em $1988^{61}$. No entanto, o que o constituinte fez foi prever sua existência e apontar as restrições de direitos e garantias que deveriam recair sobre os condenados por esse tipo de crime, deixando sua definição a cargo de futura legislação federal.

${ }^{60}$ Projeto de lei $\mathrm{n}^{\circ}$ 3754/89 encaminhado pelo Presidente da República ao Congresso Nacional pela mensagem 546/89, publicado no Diário Congresso Nacional de 28/09/1989, p. 10.605-10.606.

${ }^{61}$ A CF de 1988 dispôs no art. 5ㅜ, inc. XLVII: a lei considerará inafiançáveis e insuscetíveis de graça e anistia a prática de tortura, o tráfico ilícito de entorpecentes e drogas afins, o terrorismo e os definidos como crimes hediondos, por eles respondendo os mandantes, os executores e os que, podendo evitá-los, os omitem. Assim, a norma constitucional declinou expressamente da definição do delito hediondo, apresentando, contudo, um elenco de ilícitos que deveriam ter tratamento análogo aos hediondos, com referência a restrições de direitos e benefícios. A legislação posterior, como se verá, irá restringir ainda mais os direitos para os acusados e condenados por esses crimes. 
Franco (2000) observa que a inclusão da figura do crime hediondo na Constituição de 1988 representou a vitória, naquele momento, das forças vinculadas aos movimentos conservadores em matéria de política criminal, o que acabou por implicar ainda num deslocamento radical na (tardia) orientação garantista que havia sido instaurada com a redemocratização do país. O simples fato do texto constitucional ter previsto tal figura jurídica acabaria por referenciar toda a legislação e a intervenção repressiva criminal adotada desde então, alinhando-se essa, rigorosamente aos ditames preconizados por tais correntes antimodernas (Garland, 2005), sendo o mais destacado deles a reativação das funções retributiva e expressiva do direito penal, em detrimento de qualquer outra racionalidade empregada à punição - a prevenção, a contenção delitiva e, muito menos, a ressocialização.

\section{A LEI DOS CRIMES HEDIONDOS E O SEQÜESTRO DA POLÍTICA}

Foi turbulento o período que se seguiu à promulgação da Constituição Federal de 1988. O país já vivenciava o restabelecimento da experiência democrática no plano dos governos estaduais e municipais há alguns anos e se preparava para eleger democraticamente, após 28 anos, o mais alto posto do Executivo, o de Presidente da República.

O processo de redemocratização havia provocado mudanças importantes na configuração do poder conformada até então pelo estado policial; tais mudanças foram resultado especialmente da organização e ofensiva dos movimentos populares no período, que se caracterizou, nos termos de Oliveira, em um passo significativo no processo de desenvolvimento da política pelas classes dominadas (2000:65). A conseqüência mais importante desse processo teria sido a recuperação da fala por essas classes, consubstanciada principalmente no inventário de direitos de cidadania reivindicados e disputados na arena política que representou a Assembléia Constituinte.

Nesse contexto, alguns governos recém-eleitos no período também promoveram expectativas com relação à ampliação do acesso a direitos e dos mecanismos de participação popular, como foi o caso dos governos de Franco Montoro em São Paulo (já tematizado no capítulo anterior) e de Leonel Brizola no Rio de Janeiro. 
No final dos anos 80, entretanto, já se desenhava o início do refluxo desse processo. A mesma São Paulo que elegia Luíza Erundina à prefeitura da Capital ${ }^{62}$, numa eleição sem segundo turno, convivia com as medidas conservadoras adotadas no Estado pelo então governador Orestes Quércia, opositor aberto de seu antecessor e o principal responsável pela guinada à direita no plano das políticas sociais e em especial no que se refere à segurança pública.

Tais inflexões não podiam deixar de representar, já àquele momento, movimentos de reação por parte das oligarquias e, enfim, das classes dominantes do país, que percebiam o momento político como uma verdadeira ameaça aos seus consagrados interesses. A ameaça, por assim dizer, alcançou seu clímax quando Luiz Inácio Lula da Silva, o mais destacado líder sindical dos anos 80 e à frente do mais representativo partido da esquerda àquele tempo, o Partido dos Trabalhadores - PT -, obteve expressiva votação no primeiro turno das eleições presidenciais, garantindo-se na disputa final com seu oponente Fernando Collor de Mello.

É esse momento exato da história política e social brasileira que interessa aqui reter para a compreensão da inauguração de um novo padrão de intervenção e repressão criminal que se instaurou e para o qual a edição da Lei dos Crimes Hediondos pôde operar como marco simbólico.

O que se destaca aqui é que, da mesma forma que acontecimentos forjados levariam ao cenário que conferiria a vitória de Collor - a partir da elaboração de uma farsa, da convincente criação, por todas as forças sociais descontentes conservadoras e neoconservadoras, e com amplo apoio midiático, de um autêntico personagem, a quem se atribuiu inclusive um codinome, "o caçador de marajás" - em uma outra esfera da dinâmica social, a arregimentação de certos fatos e em determinados contextos, levaria à aprovação dessa que seria uma das legislações criminais mais polêmicas dos últimos anos: a Lei dos Crimes Hediondos, em junho de 1990.

\footnotetext{
${ }^{62}$ Foi permeado de oscilações e aparentes contradições o contexto que marcaria as eleições municipais em São Paulo no ano de 1988. Ao mesmo tempo em que se convivia com uma guinada conservadora no plano do governo estadual, na cidade de São Paulo, após o fim do mandato populista e conservador do prefeito Jânio Quadros (eleito também diretamente três anos antes), seria eleita (num só turno) uma mulher, nordestina, com uma trajetória de profundo alinhamento às lutas populares, do PT, ao governo da maior cidade brasileira, derrotando o tradicional e favorito candidato da direita, Paulo Maluf.
} 
O aumento da ocorrência de crimes violentos a partir da década 80, sobretudo nas grandes cidades, e a importância gradativa que o crime organizado passou a desempenhar no cenário das práticas criminosas (em especial na figura do tráfico de drogas), provocaram a difusão de sentimentos generalizados de medo, insegurança e indignação junto à população em geral. Essa, por sua vez, passou então a dirigir grande parte de sua fúria contra a idéia de proteção e garantia de direitos civis (dos criminosos), clamando incessantemente por maior repressão, e, na outra ponta, a intensificar os padrões de segregação social no espaço da cidade (Caldeira, 2003).

O sentimento difundido de medo e revolta com relação ao crime e ao criminoso acabou sendo apropriado e explorado com bastante eficiência pelas forças conservadoras existentes, as mesmas que haviam se sentido derrotadas em 1984 com a aprovação da legislação criminal “liberal” daquele ano. Não precisaram assim de muito trabalho ou articulação para, em poucos meses, elaborar uma série de projetos de lei que pretendiam a revogação de boa parte da legislação anterior recém-instituída, e cujo teor colidia diretamente com diversos preceitos constitucionais.

O elemento propulsor teria sido, em verdade, a ocorrência de uma seqüência de ao menos quatro crimes de extorsão mediante seqüestro - o popularmente conhecido seqüestro cujas vítimas eram famosos empresários do eixo Rio-São Paulo, entre os anos de 1989 e $1990^{63}$. A partir de então, toda a mobilização das forças mencionadas direcionar-se-ia no sentido de inscrever referido delito (especialmente atentatório às classes mais abastadas) na categoria de hediondo, tendo sido o aumento de sua incidência o teor das justificativas apresentadas nos diversos projetos de lei encaminhados ao Congresso Nacional entre o segundo semestre de 1989 e o primeiro semestre de 1990 (Franco, 2000).

${ }^{63}$ Desses, dois foram decisivos: o do empresário Roberto Medina, à época uma figura notabilizada pela promoção de eventos como o festival Rock in Rio e o do dono do grupo Pão de Açúcar, Abílio Diniz, cuja libertação ocorreria às vésperas do segundo turno das eleições presidenciais. Esse último seqüestro foi o que provocou maior comoção social, sobretudo pela tensão do momento político, em que as forças oligárquicas do país mobilizavam todos os esforços e recursos para eleger Fernando Collor e à derrubada moral de seu opositor, valendo-se, entre suas estratégias, de associar os criminosos, ligados a grupos de guerrilha de esquerda na América Latina, à própria imagem do PT. Como se verá, tal movimento, que contou com amplo suporte da mídia, teria profundo impacto não apenas junto à opinião pública, como também serviria de instrumento intimidador aos próprios políticos de esquerda no país, que passarão nesse momento a também aderir à nova onda conservadora na segurança pública, sob o temor expresso de serem acusados de "favorecer bandidos", jargão tradicionalmente usado pelas forças conservadoras. 
A aprovação do projeto de lei 5405/90, em 27/06/1990 pela Câmara dos Deputados, que viria a se tornar a Lei dos Crimes Hediondos (Lei 8072/90) resultou, em verdade, de uma manobra de lideranças especialmente representadas pelo presidente da Câmara dos Deputados à época, Inocêncio Oliveira, e do relator especial designado, o deputado Roberto Jefferson do PTB. Sua estratégia consistiu em reduzir quase a zero as possibilidades de debate de um texto apresentado de “última hora”, manejando sua aprovação através de pressões diretas a parlamentares sob a ameaça permanente do apelo à mídia. Em nome de uma "urgência urgentíssima”, nos termos do que foi alegado por Inocêncio Oliveira (DCN, 29/06/1990, p. 8229), o projeto foi apresentado atropelando uma série de outros que teriam prioridade pela antecedência do encaminhamento ou pela natureza do proponente, e votado, numa versão substitutiva (apresentada pela primeira vez aos demais deputados na própria sessão), em cerca de poucas horas.

O relator designado para substituir o parecer da Comissão de Constituição e Justiça, o deputado Roberto Jefferson, um fervoroso defensor do endurecimento penal naquele momento, apresentou um substitutivo que, à diferença do projeto em pauta (referente apenas ao crime de extorsão mediante seqüestro), incluía seis novos tipos penais ${ }^{64}$ na classificação, além daqueles que a própria Constituição já havia determinado tratamento similar aos hediondos (tortura e tráfico de entorpecentes).

A justificar a inclusão das novas figuras penais, o argumento de que haveria uma repercussão muito negativa no caso de se aprovar uma lei que "protegesse” somente as vítimas das classes economicamente mais favorecidas, como era o caso da extorsão mediante seqüestro, motivo pelo qual se incluía, então, os demais crimes. As razões para a eleição desses específicos crimes, ou mesmo a preocupação na definição de critérios pelos quais pudesse se atribuir a definição de hediondo a um delito, estiveram longe de constituir uma preocupação para o deputado relator ou para as lideranças que elaboraram o substitutivo às vésperas da votação.

A estratégia de inserir os novos crimes “de última hora” acabou gerando protestos por parte de alguns parlamentares que alegaram, obviamente, o total desconhecimento da matéria

${ }^{64}$ Eram eles: estupro, atentado violento ao pudor, latrocínio e epidemia, além dos equiparados a hediondos, terrorismo, tráfico de entorpecentes e da tortura. 
e sua impossibilidade em decidir de imediato, nos termos do que era "proposto". O debate abaixo dá exata dimensão desse impasse:

Dep. Erico Pegorara (PFL): Sr. Presidente, parece-me que seria melhor se tivéssemos possibilidade de ler o substitutivo. Estamos votando uma proposição da qual tomo conhecimento através de uma leitura dinâmica. Estou consciente. Pelo menos gostaria de tomar conhecimento da matéria.

Dep. Inocêncio Oliveira (Presidente): Então V. Exa assume a responsabilidade de pedir o adiamento da votação?

Dep. Erico Pegorara (PFL): Sr. Presidente quero que me dêem ao menos um avulso para que possa saber o que vamos votar. Estou representando o PFL e não tenho conhecimento da matéria.

Dep. Inocêncio Oliveira: O líder do seu partido tem conhecimento da matéria (...) (DCN, 29/06/1990, p. 8233).

O claro teor intimidatório com que Inocêncio Oliveira impunha a votação seria também sentido pela oposição, que, como já apontado, temia qualquer associação a atividades criminosas, sobretudo, de extorsão mediante seqüestro, depois do episódio Abílio Diniz. Desse modo, o então deputado do PT Plínio de Arruda Sampaio expôs seu temor, pedindo tãosomente o curso de uma hora para apreciar a matéria:

Dep. Plínio Arruda Sampaio (PT): Todos sabemos da responsabilidade de votar rapidamente uma lei que agrave a punição dos crimes de seqüestro para extorsão de dinheiro. No entanto, votar uma lei é ato muito grave. (...) Por uma questão de consciência, fico um pouco preocupado em dar meu voto a uma legislação que não pude examinar. Se o projeto se limitasse ao crime de seqüestro sobre o qual há consenso do Plenário poderíamos aprová-lo desde já. (...) Daqui a uma hora, leremos essa matéria com calma e então poderemos votá-la. Tenho todo o interesse em votar a proposição, mas não quero fazê-lo sob a ameaça de hoje à noite, na TV Globo, ser acusado de estar a favor do seqüestro. Isso certamente acontecerá se eu pedir adiamento da votação (...) (DCN, 29/06/1990, p. 8233).

Desse modo, ao passo de uma hora era aprovada a legislação que seria responsável por desestabilizar toda a lógica informadora de um direito penal e de um reformulado sistema de 
penas que havia se desenhado, a partir de debates, audiências públicas, denúncias, estudos e reflexões ao longo das décadas de 70 e 80 e que fora simbolizado pela reforma do Código Penal e pela Lei de Execuções Penais em 1984. Sua aprovação não deixaria de implicar ainda na inscrição de um novo capítulo na história da punição no Brasil contemporâneo.

Numa extraordinária demonstração de seqüestro da política, a questão criminal retomava o curso ao qual esteve desde sempre destinada, dando-se um primeiro e importante passo para a reconstrução de um (renovado) consenso em torno da prisão e de seus destinatários, que a aprovação dessa e de uma série de outras legislações que a seguiram foram portadoras ${ }^{65}$.

De todo o contexto em que se inseriram os episódios que levaram à aprovação da Lei dos Crimes Hediondos e, sobretudo a forma como essa aprovação foi realizada, cabe destacar aqui dois aspectos que consistem em dois eixos definidores da política criminal que se adotou a partir de então: a urgência e a exceção.

A urgência é o código pelo qual a exceção soberana é acionada e em nome da qual as regras podem ser suspensas. Foi em nome dela que as regras sobre o processo democrático puderam ser violadas sem qualquer constrangimento. A exceção, como ensinou Agamben (1998) a partir de sua leitura de Schmitt, uma vez realizando-se a partir mesmo do próprio direito através da ação soberana (que acaba por constituí-lo e assim delimitá-lo), operou aqui em sua plenitude para definir o que ficaria de fora. Definindo-se essa exclusão, a partir de então, por sucessivos instrumentos legais e infralegais, o sistema penal e a política carcerária, por conseqüência, passaram a se constituir, de modo cada vez mais preciso, em espaços preferenciais da exceção.

\footnotetext{
${ }^{65}$ Seguiu-se à lei 8072/90 (Lei dos Crimes Hediondos), a Lei 8930 /94, aprovada após intensa mobilização da autora de novelas da Rede Globo, Glória Perez, em razão do assassinato de sua filha, a atriz Daniella Perez, dois anos antes. Referida lei incluiria o homicídio qualificado (em qualquer hipótese) como delito hediondo. Seguiram-se ainda as leis 9677/98 e 9695/98 referindo-se ambas a falsificação ou adulteração de produtos terapêuticos ou medicinais, o que levaria à situação paradoxal de se classificar como hediondas condutas que vão desde a falsificação de remédios até a alteração de cosméticos.
} 


\section{O PAPEL DO JUDICIÁRIO NA POLÍTICA CRIMINAL DE EXCEÇÃO}

A Lei dos Crimes Hediondos deve ser compreendida muito mais como um passo inaugural e um marco simbólico para a reorientação das práticas punitivas no país, do que como um instrumento de impacto às taxas de delito, o que teria sido, em tese, seu objetivo ${ }^{66}$.

Sua aprovação inaugurou ainda, no país, uma nova forma de legislar no campo criminal que, em consonância à análise de Garland (2005) para os casos norte-americano e inglês, instaura a forma soberana de prescindir do conhecimento técnico (especialistas, estudiosos) e de qualquer discussão com a sociedade civil, para, em nome da urgência, proporcionar uma resposta rápida e de aparente eficácia ao problema do crime.

Essa nova prática legislativa aciona ainda de modo intenso o novo consenso sobre a necessidade do incremento do aparato repressivo como única resposta ao delito, independentemente de seus resultados práticos, ou seja, da sua parca eficácia à redução do crime. Desse modo, acaba por firmar uma nova orientação sobre a finalidade da prisão, em que prevalece seu caráter expressivo e puramente vingativo, enterrando por definitivo qualquer devaneio ressocializador ao cárcere, pese ter sido tal devaneio o eixo central da recém-editada e àquele momento já senil, Lei de Execução Penal.

Se com relação à incidência de delitos, o impacto dessa legislação de exceção não pôde ser sentido, no que toca ao encarceramento é possível traçar paralelos importantes entre o marco da aprovação dessas leis e o incremento das taxas de aprisionamento, que conheceram a partir da década de 90 os maiores números já registrados, encontrando-se até hoje em contínua ascensão. No plano nacional, como pode ser observado pelo gráfico abaixo, as taxas de encarceramento praticamente dobraram num espaço de oito anos, entre 1995 e 2003:

\footnotetext{
${ }^{66} \mathrm{Na}$ apresentação do projeto que constituiu o texto base para a Lei dos Crimes Hediondos, o relator do projeto, o então deputado Roberto Jefferson, afirmara que medidas legais como aquela em questão se de todo não impedirem esse tipo de crime, poderão dissuadir ou desestimular sua proliferação (DCN, 29/06/1990, p. 8229). É interessante notar que ao longo dos anos tal finalidade atribuída à prisão desaparecerá gradativamente dos discursos sobre a prisão, restando apenas a idéia pura e simples da retribuição e do castigo expressivo.
} 


\section{Gráfico 1}

\section{População carcerária no Brasil segundo taxa de presos por 100 mil habitantes}

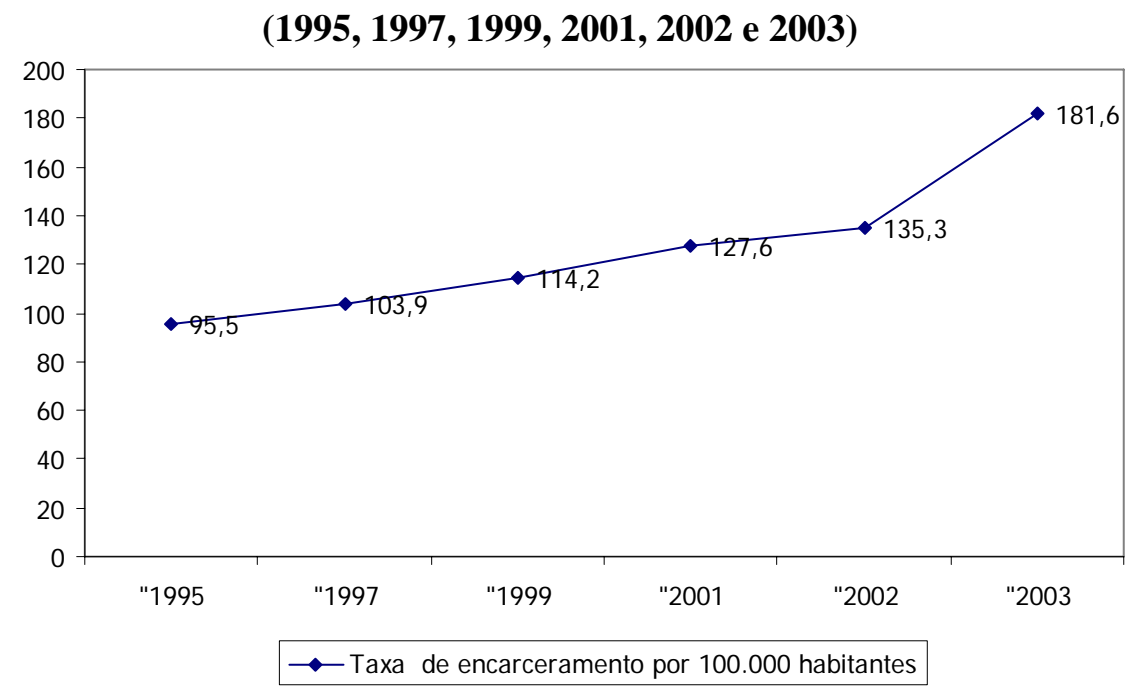

Fontes: Ministério da Justiça - Departamento Penitenciário Nacional - DEPEN; Instituto Brasileiro de Geografia e Estatística - IBGE; Instituto Latino Americano das Nações Unidas para Prevenção do Delito e Tratamento do Delinqüente - ILANUD

No que diz respeito à questão carcerária, a Lei dos Crimes Hediondos tocou em dois pontos bastante caros ao tema da execução penal que a normativa anterior (inclusive a própria Constituição Federal) havia consagrado: a individualização e a decorrente progressividade da pena.

A Lei dos Crimes Hediondos passou a exigir, à revelia de um procedimento de individualização quando da aplicação da pena ${ }^{67}$, que os condenados iniciem a pena sempre em

${ }^{67}$ Ou seja, a exigência da lei obrigou a uma desconsideração das circunstâncias específicas da ocorrência do crime e das condições pessoais do réu (como primariedade, antecedentes) para fins da classificação como hediondo e aplicação da pena. Embora afrontando o princípio da individualização da pena, tão caro ao direito penal clássico e aos estatutos liberais, essa questão só ganharia algum espaço de discussão crítica na mídia apenas em data recente, em dezembro de 2005, quando foi notabilizado o caso de Iolanda Figueiral, uma ex-bóia fria de 79 anos, analfabeta, acometida por câncer e condenada por tráfico de entorpecentes por terem sido encontradas 19 pedras de crack em sua casa na cidade de Campinas. Pelo crime ser equiparado a hediondo, o juiz que a condenou em primeira instância negou-lhe o regime aberto ou mesmo o semi-aberto, bem como qualquer atenuante em sua pena, permanecendo Iolanda numa cadeia pública durante 4 meses, período em que emagreceu 19 quilos e teve seus tumores malignos no intestino e ovário agravados, até ter obtido o direito de recorrer da sentença em liberdade pelo Tribunal de Justiça de São Paulo (Folha de S. Paulo, Caderno Cotidiano 21/12/2005). O caso ganharia repercussão em razão de protestos dos movimentos de direitos humanos dos presos e até de parte da mídia, indignados pela classificação delitiva e pela condenação imposta à D. Iolanda, bem como dividiria os próprios operadores do direito entre os que atacariam e os que defenderiam a Lei. Esse episódio é em verdade 
regime fechado e que não pudessem progredir, na execução, a um regime mais brando (que seriam o semi-aberto e o aberto), permitindo-se o livramento condicional para aqueles que não fossem reincidentes em delitos hediondos, a partir de dois terços da pena cumprida ${ }^{68}$ (e não a partir de 1/3 como dispõe o Código Penal). Em outras palavras, a entrada em vigor dessa lei teria provocado, em princípio, uma concentração maior de indivíduos nos presídios de regime fechado e por maior curso de tempo, o que vem sendo apontado como uma das causas do aumento dos índices de encarceramento.

É certo que até o momento inexistem estudos ou pesquisas científicas que tenham comprovado tal co-relação, muito embora se reconheça nos últimos anos o aumento do número de condenados em cumprimento de pena por algumas modalidades de crimes hediondos, como, por exemplo, o tráfico de drogas, o que em si não pode ser tributado com exclusividade à existência da Lei ${ }^{69}$.

A maior permanência no cárcere de indivíduos que, por apresentarem um perfil de "boa conduta” carcerária, obtinham com maior freqüência a concessão de benefícios e a liberdade antecipada, como é o caso dos homicidas primários ${ }^{70}$ e sem envolvimento com o mundo do crime, pode ser tributado como um efeito da Lei. As conseqüências se dariam não apenas no plano do incremento da população prisional, como também no funcionamento disciplinar, podendo ter levado a uma outra ordem de instabilidades e a novos arranjos e distribuições de poder no interior do sistema.

Por outro lado, a ordem de restrições imposta pela nova Lei dirigiu-se essencialmente à atividade decisória do juiz (da condenação e da execução). Seu impacto direto, portanto, poderia ser esperado na medida em que importasse a mudança de um padrão decisório, em outras palavras, na medida em que tivesse imposto orientação mais conservadora à jurisprudência. Os estudos sobre o funcionamento do sistema de justiça criminal, contudo,

ilustrativo dos efeitos desastrosos da aplicação de uma legislação que não levou em conta uma lógica e um sistema de aplicação de penas construído pelo ordenamento jurídico vigente.

${ }^{68}$ Vedou a Lei ainda o livramento condicional, em qualquer hipótese, para os reincidentes específicos em delitos hediondos.

${ }^{69}$ Há que se ponderar acerca da atividade policial, que pode ter intensificado a persecução a esse tipo de delito, de forma autônoma a existência da lei.

${ }^{70}$ Essa é uma percepção, sobretudo de operadores de direito que atuam na esfera da execução penal em São Paulo, colhida a partir de conversações informais travadas sobre os possívies efeitos da Lei. 
com especial destaque em São Paulo, revelam que sua lógica informadora tem-se mantido, ao longo dos anos, adstrita a um modelo de atuação racista, classista e, é claro, portador de um irrestrito conservadorismo, a partir de uma leitura do direito penal sob a exclusiva ótica da segregação e da negação a direitos.

Uma pesquisa realizada na Vara de Execuções Criminais da Capital de São Paulo junto a processos de execução, em curso mesmo antes da Lei dos crimes hediondos, demonstrou que apenas 22\% dos presos obtinham a progressão de regime, e a não mais de $8 \%$ era concedido o livramento condicional (Teixeira e Bordini, 2004). A mesma pesquisa apontou a uma clara predisposição por parte dos juízes em denegar benefícios, uma vez que identificou um aproveitamento ideológico dos laudos criminológicos realizados: quando o parecer desses era desfavorável, em $87 \%$ as decisões o acompanhavam indeferindo o benefício; já quando ocorria o contrário e o resultado era favorável ao preso, apenas $45 \%$ das decisões concediam o benefício acolhendo o laudo. Do mesmo modo, o lapso para a primeira concessão superava em muito a previsão legal: 75\% dos presos que obtiveram a progressão já haviam cumprido mais de 1/3 de sua pena e não 1/6 como dispõe a LEP.

Logo, a entrada em vigor da Lei 8072/90 teria encontrado, na esfera da execução penal, um campo no qual a atribuição de direitos já vinha sendo reiteradamente negada, e cuja orientação já ia ao encontro da Lei, podendo ter sido apenas acirrada por ela.

Quanto à esfera da condenação, a intensificação da punitividade após a edição da Lei é uma leitura possível, sendo ainda certo que, tomando-se o caso de São Paulo, o maior grau de punição tenha se verificado não apenas aos crimes hediondos, mas se disseminado como um novo padrão de atuação judicial alcançando os tipos penais de maior ocorrência.

O Estado de São Paulo, que abriga quase a metade da população encarcerada do país, conheceu, ainda com mais eloqüência do que no nível nacional, o aumento de suas taxas de encarceramento a partir de década de 90, como indicam os gráficos a seguir: 


\section{Gráfico 2}

População carcerária de São Paulo segundo taxa de presos por 100 mil habitantes (1984-1993)

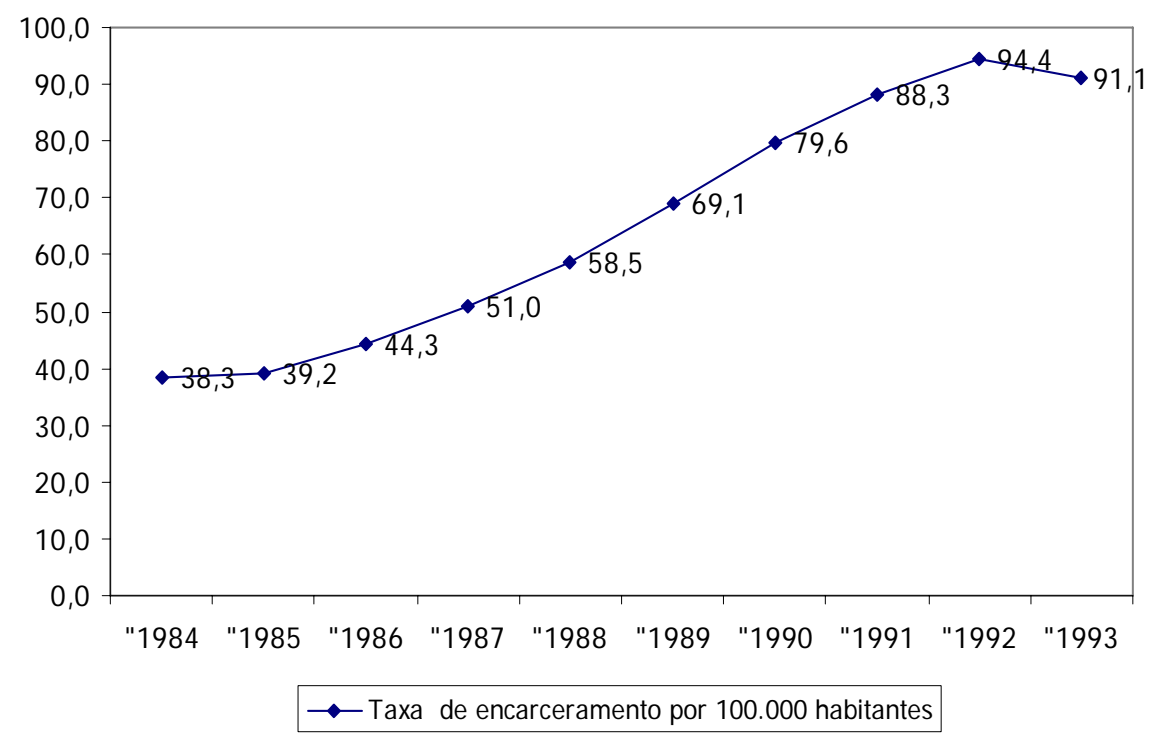

Fontes: Coordenadoria dos Estabelecimentos Penitenciários de São Paulo - COESPE; Instituto Latino Americano das Nações Unidas para Prevenção do Delito e Tratamento do Delinqüente - ILANUD

\section{Gráfico 3}

População carcerária de São Paulo segundo taxa de presos por 100 mil habitantes (1994-2003)

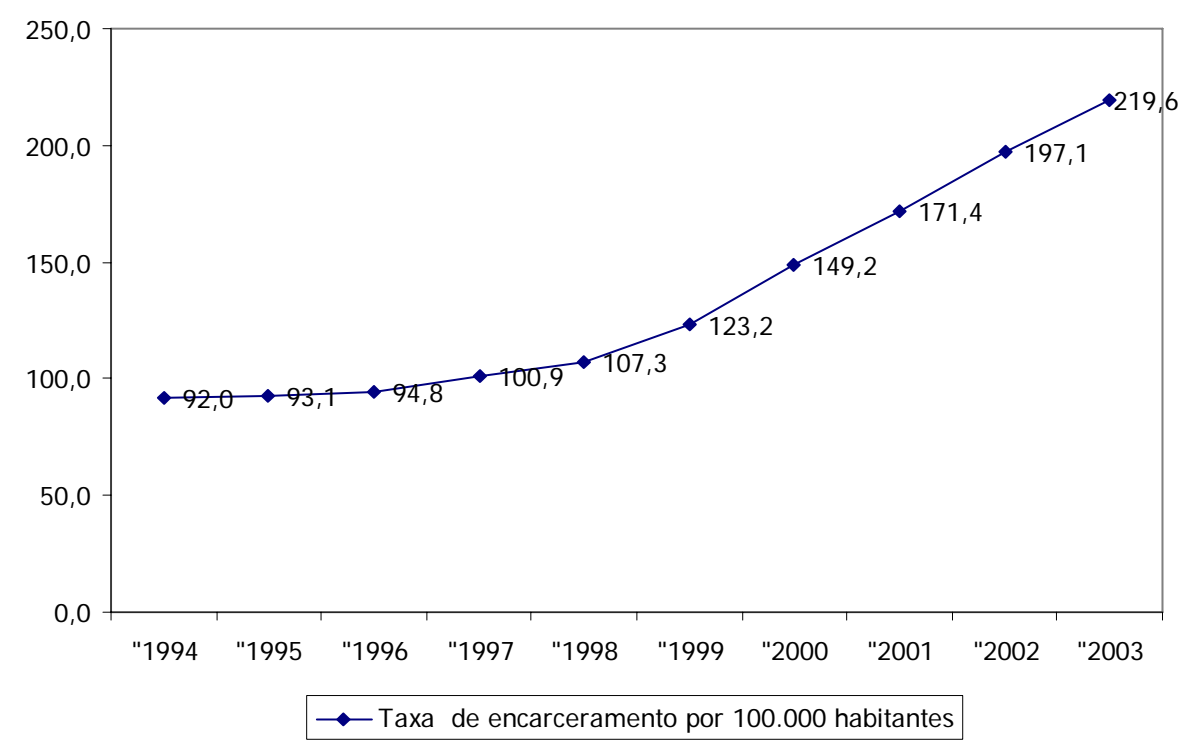

Fontes: Secretaria de Administração Penitenciária - SAP/SP; Fundação Sistema Estadual de Análise de Dados e Estatística - SEADE; Instituto Latino Americano das Nações Unidas para Prevenção do Delito e Tratamento do Delinqüente - ILANUD 


\section{Gráfico 4}

População encarcerada no Estado de São Paulo em números absolutos (1996-2005)

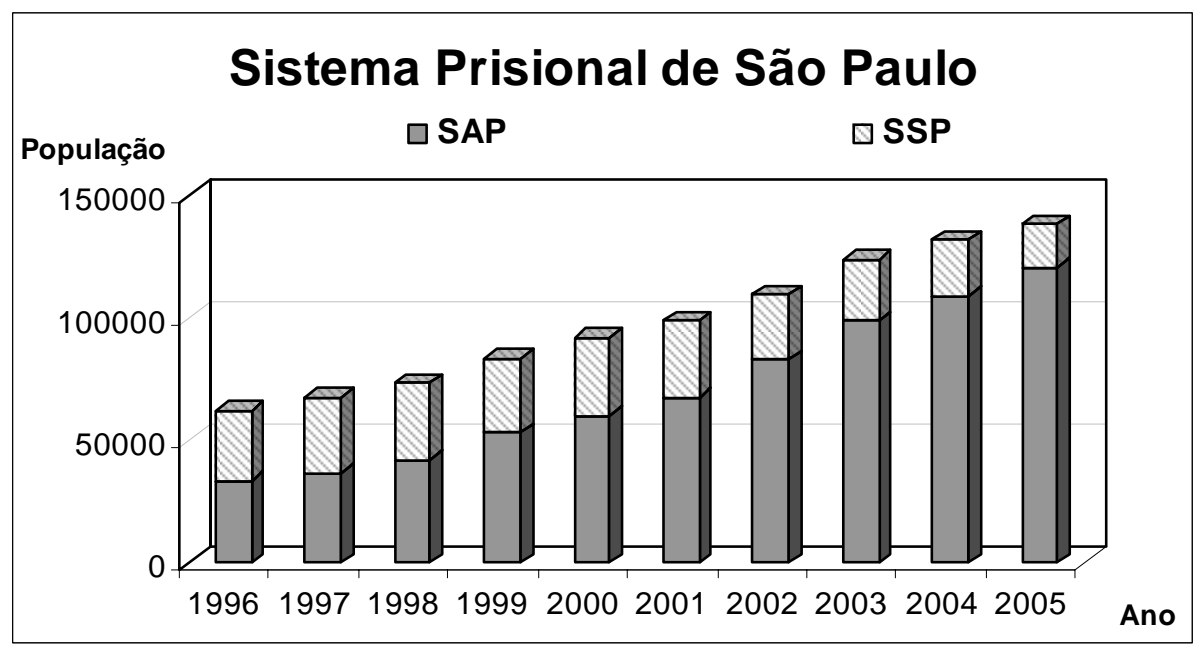

Fonte: Secretaria de Segurança Pública - SSP/SP e Secretaria de Administração Penitenciária - SAP/SP

As taxas de encarceramento em São Paulo, que já se mostravam progressivas desde 84, assumem a partir de 1999 um crescimento mais frenético, chegando a registrar a marca de 219,6 presos por mil habitantes em 2003, conforme os gráficos 3 e 4, levando-se em consideração essencialmente os presos sob custódia da COESPE e SAP, portanto os condenados no sistema ${ }^{71}$. A elevação constante e em ritmo intenso é ainda mais evidente se considerarmos os números absolutos de presos sob custódia das duas Secretarias (SAP e Segurança Pública), que saltam da ordem de 60 mil em 1996 para mais de 140 mil presos em 2005 (gráfico 5).

Esse imenso contingente prisional, que já se encontrava na faixa de 143.310 presos em julho de $2006^{72}$, está em sua maioria cumprindo pena pelo crime de roubo, $46,5 \%{ }^{73}$ dos

\footnotetext{
${ }^{71}$ A partir de 1999, o número de presos sob custódia da SAP irá intensificar-se em razão do processo de desativação das carceragens dos DPs e da Casa de Detenção da Capital, com a conseqüente transferência dos presos sem condenação para essa Secretaria.

${ }^{72}$ Segundo a SAP são 125.783 presos sob sua custódia, estando o restante ainda sob tutela da Secretaria de Segurança Pública, ou seja, detidos em cadeias públicas e distritos policiais no Estado. Fontes: SAP/SP e SSP/SP.

${ }^{73}$ Segundo Censo Penitenciário do Estado de São Paulo, realizado pela SAP em 2002 (FUNAP/SAP, 2002).
} 
condenados, um delito que não é classificado como hediondo pela legislação vigente ${ }^{74}$. Assim, não obstante o incremento do crime organizado e das mortes violentas, sobretudo nas periferias das grandes cidades, o crime de roubo permanece como o grande alvo do aparato repressivo em São Paulo, sendo seguido em percentuais bastante inferiores pelo furto (12\%), que é um crime patrimonial de baixo potencial ofensivo ao qual se prevê inclusive a possibilidade de aplicação de pena alternativa.

Os delitos de tráfico de entorpecentes e homicídio respondem respectivamente por 11\% e 9\% das condenações de presos em São Paulo, demonstrando que, ao contrário do que poderia supor o senso comum, embora tais modalidades se enquadrem mais precisamente a um novo padrão delitivo que tem no crime organizado sua melhor representação, e não obstante sua ocorrência venha a ocupar um papel de destaque na geografia do crime nas grandes cidades e nos debates sobre a política de controle do crime, o Estado continua a punir predominantemente o crime patrimonial de roubo ${ }^{75}$.

Não por acaso os estudos sobre o funcionamento do sistema de justiça criminal paulista têm conferido especial atenção ao processamento desse delito, chegando a resultados que conferem a dimensão da seletividade do sistema e, enfim, da cultura dominante entre seus operadores, juízes especialmente.

O primeiro deles, realizado pelo Núcleo de Estudos da Violência da USP - NEV apontou a desigualdades importantes no tratamento da justiça para réus negros e brancos, como o maior número de prisões, o menor grau de acesso à justiça e de ampla defesa, e a maior incidência de condenações, sempre em desfavor dos réus negros (Adorno, 1995). No mesmo sentido, um levantamento de dados estatísticos oficiais no Estado a respeito de inquéritos e processos criminais de roubo, realizado pela Fundação Seade, demonstrou a inversão de trajetória de negros e brancos no interior do sistema de justiça, concluindo pela maior punição aos negros, em especial às mulheres negras. O mesmo trabalho revelou o

\footnotetext{
${ }^{74} \mathrm{O}$ art. 157 do Código Penal define o crime de roubo como a subtração de bem alheio móvel mediante qualquer meio que constranja a vítima, não se exigindo violência real, apenas a ameaça.

${ }^{75}$ A ausência da produção de dados nacionais mais detalhados que indiquem, por exemplo, o motivo da condenação, impede que se tenha um conhecimento da realidade nacional bem como das especificidades de cada Estado. O único censo penitenciário nacional foi realizado em 1994 e apontava àquela época o roubo como o crime de maior incidência, correspondendo a 32,9\% entre os presos do país, sendo seguido pelo furto $16,4 \%$ e pelo tráfico de entorpecentes 10,6\% (ILANUD, 1997).
} 
altíssimo percentual de sentenças condenatórias para esse tipo de crime: 90,22\% (FSeade, 2003).

Se o perfil de condenados por esse crime já sugere um tratamento discriminatório e a presença de fortes vieses na atuação da justiça, é pela análise do teor das sentenças que se desvela com mais nitidez as motivações ideológicas que integram o universo discursivo e as práticas do sistema, sobretudo a partir da (re)construção de conceitos ainda prementes no tratamento da questão criminal - tais como a idéia de periculosidade “imanente” à criminalidade -, autorizadores de um padrão de intervenção que prima pela segregação.

Uma pesquisa realizada a partir de decisões condenatórias nos crimes de roubo analisou os fundamentos utilizados pelos juízes para a aplicação da pena, destacando uma sorte de "expressões estanques" (usadas nos mesmos termos, em diferentes casos, para diferentes réus e por diferentes juízes) classificadas, metodologicamente, em três categorias: periculosidade, defesa de sociedade e gravidade do crime. Cada uma delas correspondeu a percentuais importantes das decisões (56,9\%, 41,6\%, 60,8\% respectivamente) que foram mobilizados como fundamento principal para o agravamento da pena e para imposição do regime fechado (IBCCRIM/IDDD, 2005).

Constatou-se que o emprego dos termos ocorria de modo abstrato, para se referir à generalidade dos réus presumidamente perigosos e de personalidade distorcida que cometem crime de roubo, um crime gravíssimo, definido como um dos que mais comovem $e$ atormentam a população ordeira e trabalhadora dessa terra (IBCCRIM/IDDD, 2005: 44). Desse modo, não obstante tratar-se, em 78\% dos casos, de indivíduos primários, e em 77\% sem condições específicas que permitissem a pena-base ser agravada acima dos que se denomina “mínimo legal”, também em 77\% das decisões o regime imposto foi o fechado. Para justificar o acirramento da condenação, o trecho de uma decisão é ilustrativo: mesmo que o réu seja primário e com bons antecedentes, em casos de roubo qualificado emerge a periculosidade e a capacidade criminógena da natureza mesma do delito praticado e do comportamento exercido, já que tal periculosidade é ínsita à conduta desenvolvida (IBCCRIM/IDDD, 2005:50). 
Mobilizando ainda as noções de punição exemplar e repudiando aquilo que foi definido como sentimentos generosos de liberdade e igualdade (IBCCRIM/IDDD, 2005:54), os juízes menosprezam expressamente as concepções liberais ainda vigentes no plano legal da proporcionalidade e da individualização da pena. Ademais, embora fazendo uso de algumas categorias da escola positiva do século XIX, também não demonstram qualquer apego à idéia do criminoso como doente e da pena como tratamento, alinhados muito mais às já citadas contemporâneas construções morais do delinqüente como um monstro voraz e inescrupuloso que precisa ser contido, segregado, realçando ainda o caráter expressivo da pena, a fim de acomodar sentimentos vingativos de parcela da sociedade de bem.

Essa avaliação do comportamento da justiça criminal pode demonstrar assim a apropriação de um certo conteúdo que a Lei dos Crimes Hediondos foi portadora, para além dos crimes que a integraram. Esse conteúdo diz respeito a novas percepções sobre o crime e a punição, nas quais a restrição de direitos e a excepcionalidade das garantias dos acusados prevalecem para afirmar um direito penal que tem ainda no emprego indiscriminado da pena de prisão e na crença de sua aplicação desprovida de qualquer finalidade para além do encarceramento em si, sua manifestação aparente.

Portanto, mais importante do que estabelecer uma direta relação do tipo causa e efeito entre a Lei dos Crimes Hediondos e o aumento do encarceramento, é compreender essas práticas enquanto expressões de um mais amplo e complexo fenômeno que diz respeito às novas orientações que têm marcado a política criminal contemporânea, em que, sobretudo o papel da prisão e a figura atribuída ao preso têm sido redesenhados.

O que se destaca assim como decisivo com relação à legislação criminal de exceção dos anos 90 é seu papel simbólico e sua influência na conformação de um novo padrão punitivo, na medida em que propagou e consolidou novas formas de representação com relação à intervenção criminal, que afetaram, como pôde ser demonstrado, modalidades criminais para além daquelas etiquetadas pela Lei. Em verdade, foi a própria inexistência de uma definição acerca de crime hediondo que permitiu que os efeitos de sua sanção (a maior punitividade e a restrição de direitos) pudessem se generalizar a ponto de constituírem o fundamento desse novo modus punitivo, no qual o crime per si passa a ser tratado, para fins de sua reação, como hediondo. 
Vê-se, de tal modo, que é no âmbito das representações e dos sentidos conferidos à punição pelos atores que deveriam ser encarregados de, ao mesmo tempo em que aplicá-la tutelar os direitos dos acusados e condenados, que se opera cotidianamente e com mais relevo esse deslocamento do paradigma da prisão da ressocialização à incapacitação e a construção da nova figura moral do criminoso, que se não é totalmente nova uma vez que reatualiza estereótipos de um positivismo nunca superado, traz diferentes conteúdos a ponto de autorizar sua destituição de um estatuto jurídico.

A contemporaneidade penal tem revelado com especial relevo o papel desempenhado pelo sistema de justiça na engenharia da punição: a ele incumbe hoje a desconstrução do mito do sujeito de direitos, em defesa do qual, ironicamente, sua existência fora antes justificada. Com o fim do welfarismo penal no primeiro mundo e da breve aposta ressocializadora à brasileira, os juízes podem agora expressar sem qualquer constrangimento o decisivo papel que Foucault lhes atribuiu, os de dóceis empregados - quase nunca rebelados - no mecanismo de produção da delinqüência (1997a: 234). 


\section{CAPÍtulo IV}

\section{UMA POLÍTICA PENITENCIÁRIA CALCADA NA EXCEÇÃo}

SUMÁRIO: 1. A radicalização da violência institucional entre 1987-1994 e sua legitimação; 2. O contexto de surgimento do Primeiro Comando da Capital - o PCC; • O Centro de Readaptação Penitenciária de Taubaté, o "Piranhão", como espaço preferencial da exceção; • Somos fortes onde o inimigo é fraco; 3. A gestão de Nagashi Furukawa (1999-2006) e a nova racionalidade penitenciária; • Precedentes: a questão criminal no primeiro Mandato de Mario Covas (1995-1998); • A exceção generalizada do RDD e a "ressocialização" dos CRs: dois tempos de uma história; • A nova LEP de 2003: a soberania administrativa e o novo estatuto jurídico do preso.

A relação de exceção é uma relação de bando. Quem é banido, não é simplesmente posto fora da lei, de modo a que esta lhe é indiferente, é abandonado por ela, ficando exposto e em risco no limiar em que vida e direito, exterior e interior se confundem.

(Giorgio Agamben, Homo Sacer I, p. 36)

\section{A RADiCALIZAÇÃo DA VIOLÊNCIA INSTITUCIONAL ENTRE 1987-1994 E SUA}

\section{LEGITIMAÇÃo}

Se fosse possível contar a história do sistema penitenciário paulista em atos, como a encenação de uma peça teatral, certamente o episódio que sucederia ao fracasso da política de humanização do governo Montoro na década de 80 seria o Massacre do Carandiru, em outubro de 1992.

A tragédia dos 111 presos exterminados pela Polícia Militar no maior presídio da América Latina reescreveu a trajetória do sistema penitenciário nacional e marcou de modo profundo também a história da prisão em dimensões para além do território nacional. Pois, pela primeira vez na existência dessa instituição total, um governo de um Estado democrático autorizava a eliminação de um contingente expressivo de indivíduos (cidadãos?) que cumpriam suas penas, aplicadas mediante o devido processo legal, em um estabelecimento concebido e gerido, inclusive jurisdicionalmente, para assegurar-lhes não apenas a vida e a integridade física como também as “condições para sua harmônica 
reintegração social ${ }^{77, ”}$. Existia ainda, entre os exterminados, uma parcela significativa que não havia sido sequer condenada, que respondia a seus processos presa cautelarmente, e a favor da qual regia o desusado princípio da presunção da não culpabilidade, princípio esse especialmente caro à constituição do Estado de direito.

O Massacre, embora tenha sido um fato extremo, consistiria, sobretudo, em um desdobramento lógico da política de segurança pública adotada a partir do governo de Orestes Quércia e intensificada por seu sucessor, Luiz Antonio Fleury Filho, um promotor de justiça "linha dura” que havia sido Secretário de Segurança no governo antecessor.

Após o fim do mandato de Montoro e o fracasso das medidas humanizadoras para os presídios e de controle à violência policial, os governos seguintes se impuseram a tarefa de “endurecer” o tratamento em matéria de segurança, o que significou a reversão de um quadro que havia sido marcado pela tentativa de restabelecimento do Estado de direito nessa área, como uma das promessas acenadas pela redemocratização.

Durante os anos de 1987-1994, sob declarada guerra ao crime, a polícia de São Paulo obteve mais uma vez na sua história a autorização expressa para usar da violência e do arbítrio em sua tarefa cotidiana, o que significou um aumento importante das taxas de letalidade de civis em ações da Polícia Militar. A respeito, Caldeira resgata uma declaração feita pelo então governador Luiz Antonio Fleury em 1989, no sentido de justificar o aumento de mortes provocadas pela Polícia pelo fato dessa estar mais “atuante” frente ao crime, o que implicaria em maiores situações de confronto entre "marginais" e policiais (Caldeira, 2003:171).

É certo ainda que, durante o período dos governos Quércia e Fleury, não apenas a Polícia receberia autorização para a discricionária eliminação de civis, como o padrão de intervenção nos presídios seria pautado pela mesma rotinização da tortura e da violência, muitas vezes letais. Assim, para além do desmonte das pontuais iniciativas do governo anterior, foi o eixo axiológico e estratégico da atuação frente à questão carcerária que se deslocou. Mais uma vez a promessa de constituição do sujeito de direitos e de politização da questão criminal seriam suplantadas por uma orientação de cerceamento de direitos e violência institucional que se explicitaria no domínio mesmo da própria Administração. Essa “orientação” passaria a ser adotada como discurso oficial por governos que não

\footnotetext{
${ }^{77}$ De acordo com o estabelecido pelo art. $1^{\circ}$ da Lei de Execuções Penais como a principal finalidade da pena privativa de liberdade.
} 
escondiam sua filiação a interesses ultraconservadores em matéria de segurança pública em detrimento da preservação e garantia aos direitos humanos, se valendo ainda de um conclamado apoio popular para legitimar suas práticas, o que conferiu ainda uma aura especialmente totalitária a tal intervenção ${ }^{78}$.

A política penitenciária adotada no período seria, desse modo, declaradamente a de contenção, ou seja, a de intensificação do uso da força para o controle e o gerenciamento da massa carcerária, em detrimento de qualquer outra proposta que levasse em conta o caráter ressocializador da pena, em que pese a Lei de Execução Penal ter entrado em vigor alguns anos antes.

Para se ilustrar tal “orientação” da política carcerária adotada nesse momento, destacam-se aqui dois episódios marcantes que antecederam ao Massacre e que dão conta da violência institucional praticada no período. O primeiro episódio se refere a um motim ocorrido na Penitenciária do Estado, em julho de 1987, cuja “intervenção” da Polícia Militar resultou na morte de 31 presos (Caldeira, 2000). O fato de não ter havido morte por parte dos agentes penitenciários ou policiais contribuiu na indicação da ausência de confronto ou resistência por parte dos detentos quando da ação, do mesmo modo com o que ocorreria no Massacre do Carandiru, seis anos depois. Para se ter uma dimensão da truculência dessa ação de 1987, a megarreblião promovida pelo PCC em fevereiro de 2001, envolvendo 29 unidades prisionais e 28 mil presos, teria como saldo a morte de 19 deles, provocadas em maioria pelos próprios detentos, portanto pouco mais da metade do incidente em 1987 que envolvera um número muito mais reduzido de pessoas, num único estabelecimento carcerário.

O segundo episódio que também ganharia destaque não apenas pelo número de mortos, como pela atrocidade da forma de sua "execução", ocorrera em 1989, no $42^{\circ}$ Distrito Policial em São Paulo, quando 18 presos morreram asfixiados após terem sido

\footnotetext{
${ }^{78}$ Como aponta Teresa Caldeira (2003), a Rota (Rondas Ostensivas Tobias de Aguiar, uma divisão da Polícia Militar que se notabilizaria pelas mortes de civis até a década de 80) contava com grande respaldo popular, como indicou uma pesquisa de opinião realizada pelo Jornal Folha de S. Paulo em dezembro de 1982, quando 85,1\% dos entrevistados se mostraram contrários à sua extinção. Em 1983, em pleno governo Franco Montoro, a população já se "ressentia” da política de segurança pública que vinha sendo adotada, tendo o mesmo jornal divulgado uma pesquisa na qual 71,8\% requeriam uma política mais dura no combate à criminalidade. Como se discutirá adiante, o apoio às ações de extermínio no sistema carcerário também contou com certo respaldo popular. Sobre o caráter totalitário desse populismo penal, uma declaração feita pelo Comandante da Rota no contexto das eleições estaduais de 82 é ilustrativa: "Nós - a Rota - somos a única coisa que os bandidos temem. E como diz uma velha frase, o medo leva ao respeito, que se transforma em admiração e conduz ao amor (Folha de S. Paulo, 10 de outubro de 1982) (Caldeira, 2003: 169)”.
} 
confinados 50 homens em uma cela forte de aproximadamente três metros durante muitas horas, como "punição" a uma frustrada tentativa de fuga ${ }^{79}$.

O fato, para além de expor os horrores experimentados por milhares de presos que são depositados nas carceragens dos distritos policiais e cadeias públicas no Estado ${ }^{80}$, locais que, embora impensados para esse fim, comportam imensos contingentes de indivíduos, muitos deles em cumprimento definitivo de pena há anos, revelou ainda a barbárie com que as ações de agentes públicos encarregados pela custódia de determinados seres humanos podem se revestir. Demonstrou também como a lógica do extermínio pode ser acionada assim, de forma cotidiana e banalizada, uma vez que a condição de uma vida politicamente qualificada a que $\mathrm{H}$. Arendt (2001) se refere é completamente convertida em zoôe, na vida natural e matável (Agamben, 1998), numa situação na qual o direito é completamente capturado pelo biopoder, de dentro e a partir mesmo do próprio Estado (democrático) de direito.

O ponto de culminância dessas práticas foi, desse modo, o Massacre na Casa de Detenção do Carandiru em 2 de outubro de 1992, tendo representado o ápice de tal lógica. É certo, contudo, que a repercussão alcançada em virtude da magnitude do episódio contribuiu de modo importante ao advento de mudanças ao aperfeiçoamento e à

\footnotetext{
${ }^{79} \mathrm{O}$ fato receberia uma grande repercussão inclusive internacional, tendo ensejado uma representação contra o governo brasileiro junto a Corte Interamericana de Direitos Humanos da OEA. Até hoje, apenas o carcereiro envolvido diretamente no crime foi condenado em primeira e segunda instâncias pelo caso (TJ confirma pena de implicado em chacina de presos, Jornal Folha de S. Paulo, 14/03/1997); O delegado responsável, contudo, foi absolvido pelo $1^{\circ}$ Tribunal do Júri nos dois julgamentos realizados (Tribunal do Júri absolve delegado do $42^{\circ}$ distrito, Jornal O Estado de S. Paulo, 14/12/1998), e embora o Ministério Público tenha recorrido requerendo a realização de um terceiro julgamento, o TJ indeferiu o recurso mantendo a absolvição. O investigador foi absolvido quando da realização de um segundo júri e o recurso interposto pelo MP contra a decisão tramita há quase três anos no TJ.

${ }^{80} \mathrm{O}$ dantesco retrato das carceragens nas cadeias paulistas já foi relatado em visitas de representantes da OEA e da ONU (em 1996 e 1997), que narram os horrores do confinamento de centenas de pessoas em espaços sem qualquer condição de salubridade, sem a luz do sol, onde as moléstias proliferam, o que teria os levado a definir as condições apresentadas como animalescas (OEA, Comissão de Direito Humanos, Relatório sobre a situação dos direitos humanos no Brasil, 1996 e ONU, Comissão de Direitos Humanos, Relatório sobre a Tortura no Brasil, 1997. Essas impressões vão ao encontro da declaração feita posteriormente pelo próprio Secretário de Segurança Pública à época, Marco Petrelluzzi, de que um campo de concentração nazista seria um avanço comparado às carceragens paulistas (Folha de S. Paulo, 20/12/2000) (Martins, 2001). As carceragens dos Distritos Policiais acabariam sendo desativadas em novembro de 2005, contudo, os Centros de Detenção Provisória criados para abrigar essa população presa sem condenação já se encontram em situação de superlotação, e em condições de acentuada precariedade. Com relação às cadeias públicas, é certo que ainda se encontram em pleno funcionamento no Estado, inclusive na Capital que abriga a maior delas, o DACAR de Pinheiros- Delegacia de Vigilância e Capturas - onde estão detidos milhares de presos e presas, elas inclusive em número quase idêntico a todas as reclusas em presídios (SAP), e em números proporcionais muito superiores aos homens presos, o que denota um especial descaso e esquecimento em relação às mulheres encarceradas, para as quais nem a mais básica medida é cumprida, o oferecimento de uma vaga em uma penitenciária para o cumprimento de sua pena.
} 
instrumentalização na luta contra a impunidade diante das violações de direitos humanos cometidas pelo Estado. Nesse sentido, a aprovação da lei que transferiu da Justiça Militar para a Justiça comum o julgamento de crimes dolosos contra a vida ${ }^{81}$, praticados por policiais militares no exercício da função, foi uma medida de especial relevância, possibilitando que em casos como o Massacre, incluindo o próprio, seus responsáveis pudessem processados e julgados com a devida publicidade e, a princípio, por instâncias mais isentas e democráticas.

No plano da política penitenciária local, algumas mudanças acabaram sendo impostas ao governo, a primeira delas, mais óbvia e de efeito sobretudo simbólico, foi a mudança do titular da Secretaria da Segurança, responsável pela operação da polícia militar no episódio. A segunda e mais importante medida referiu-se à criação da Secretaria de Administração Penitenciária ${ }^{82}$, a primeira do país, em 04 de janeiro de 1993, através da Lei estadual de $n^{0}$ 8209. Assim como a criação da COESPE em 1979 representara um avanço no sentido de dotar o sistema de maior racionalidade administrativa e autonomia, a criação de uma Secretaria de Estado atendia ainda com mais precisão a tais expectativas. No entanto, como se verá adiante, a existência da SAP, embora possa ter conferido, em alguma medida, maior independência à formulação e à definição das diretrizes da política penitenciária estadual, não se mostraria, contudo, eficiente para desvencilhar a questão carcerária de seu tradicional alinhamento à temática da segurança e da repressão, e, acima de tudo, não seria capaz de vencer a prevalência de uma determinada subcultura prisional fortemente consolidada a partir dos abusos do poder disciplinar e da corrupção.

Muito embora se reconheça que a ocorrência do Massacre tenha trazido novamente a questão carcerária e, em última análise, a discussão sobre os direitos humanos de pessoas privadas de liberdade de volta ao centro do debate, retomando em alguma medida sua

\footnotetext{
${ }^{81}$ O projeto original de autoria do então deputado federal Helio Bicudo do PT/SP previa a competência da Justiça comum para processar e julgar todos os crimes cometidos no exercício da função. O projeto foi apoiado pelo Ministro da Justiça à época e aprovado na Câmara dos Deputados, recebendo no Senado um substitutivo de autoria do senador Genebaldo Correia do PMDB/BA, que restringiria a competência da Justiça comum apenas aos crimes dolosos contra a vida, tendo sido afinal esse o texto aprovado e sancionado pelo Presidente da República como a lei 9299/96 (César Caldeira, 2000).

82 Até 1991, cabia à Secretaria de Justiça a responsabilidade sobre a administração penitenciária, remanescendo à Secretaria de Segurança Pública, a custódia dos presos detidos em distritos e cadeias públicas. Durante o governo Fleury, em março de 1991, a competência também sobre a administração dos presídios seria transferida à Secretaria de Segurança Pública, o que representou um grande retrocesso no tratamento da questão carcerária. Após o Massacre, uma Secretaria autônoma seria então criada para a finalidade exclusiva da administração das unidades prisionais (fonte: www.admpenitenciaria.sp.gov.br, acesso em 16/03/2006).
} 
dimensão polêmica, não se assistiu neste momento, contudo, a uma inversão de trajetória a partir da qual ela voltasse a reassumir a potência de conflito e dissenso de outrora. Ao contrário, ao ter operado também como marco simbólico, o episódio representou o fim das aspirações a uma política carcerária humanizadora e guiada pela finalidade da ressocialização.

O Massacre traria ainda cifrada uma mais importante mensagem: a de que a questão carcerária seria passível de outras soluções, e, mais importante ainda, soluções essas dentro das margens mesmo do Estado de direito. A senha dessa mensagem foi a legitimação ao Massacre conferida pelo Estado em suas três esferas de poder, sobretudo pelo Judiciário que, ao não punir seus agentes declarando ainda sua inocência, foi o mais importante propagador dessa nova percepção.

O processo de legitimação do Massacre pode ser identificado nos diferentes âmbitos de atuação dos poderes do Estado. Primeiramente, na esfera do Poder Executivo, pelo não afastamento dos policiais diretamente envolvidos no Massacre e muito menos das autoridades responsáveis por sua execução. A respeito, é de se registrar que não apenas o governador Fleury seria posteriormente eleito de forma sucessiva à Câmara Federal, destacando-se como um influente parlamentar nas questões relacionadas à temática da segurança, em especial no que toca às legislações criminais de exceção, como o próprio Coronel Ubiratan seria candidato sucessivas vezes ao parlamento ${ }^{83}$ do Estado de São Paulo, tendo sido eleito na maior parte delas. Em todas as campanhas, recorreu ao episódio do Massacre como slogan, trazendo o sugestivo número 111 em sua candidatura, fato, aliás, que não recebeu qualquer impugnação ou mesmo censura por parte da Justiça Eleitoral ou do Ministério Público, a quem incumbiria a devida fiscalização nessa área.

No âmbito do Legislativo, instaurou-se uma CPI na Assembléia Legislativa do Estado com a finalidade de apurar os fatos ocorridos no Pavilhão 9 da Casa de Detenção. O relatório, publicado no Diário Oficial em 05.12.1992, limitou-se em seus 10 itens a reconhecer a inevitabilidade do ingresso da PM no presídio, apontando apenas seu excesso e insistindo no fato de que a Comissão não fora capaz de apurar responsabilidades

\footnotetext{
${ }^{83}$ Ubiratan Guimarães foi candidato também a deputado estadual e também recorrendo ao número 111 no número de sua candidatura (14.111) nas últimas eleições de 2006. Ubiratan seria, entretanto, assassinado em 10/09/2006, ao que tudo indica vítima de um crime passional, encerrando assim não só suas pretensões eleitoreiras, como mais um capítulo na história das prisões brasileiras. Com sua morte, o desfecho de sua responsabilização quanto ao Massacre do Carandiru acabou por ser foi o da absoluta impunidade, tendo em vista sua absolvição pela justiça criminal, como será discutido adiante.
} 
individuais em razão de ausência de elementos técnicos (Relatório Final, D.O.E. 02/12/992). Evidentemente que não caberia a esse Poder proceder à apuração das responsabilidades criminais imputadas individualmente, procedimento que compete à justiça criminal no âmbito do devido processo legal. Ao Legislativo caberia, entretanto, politizar o episódio, no sentido de problematizar as diretrizes adotadas pelo Governo na questão prisional em seus contextos mais amplos. No entanto, ao reduzir os acontecimentos e atribuir a responsabilidade do desfecho a executores da operação de modo individual, transformou o Massacre em um mero acidente, uma fatalidade, contribuindo ainda mais para sua legitimação ${ }^{84}$.

Por fim, a mais importante medida de impunidade seria conferida pelo Poder Judiciário ao absolver o responsável pelo comando da operação que resultou no Massacre do Carandiru, o Coronel Ubiratan Guimarães, em 15 de fevereiro de 2006. O acórdão, proferido pelo Órgão Especial do Tribunal de Justiça de São Paulo, núcleo de maior concentração de poder no âmbito da organização da justiça no Estado, composto pelos 25 desembargadores mais antigos na carreira ${ }^{85}$, anulou a decisão condenatória que havia sido tomada em 2001 pelo $2^{\circ}$ Tribunal do Júri da Capital.

A absolvição acabou por ferir a soberania do Tribunal do Júri, uma vez que proferiu nova decisão no lugar daquela tomada pelos jurados, ao invés de ter-se designado novo julgamento, o que seria o esperado no caso do Tribunal de Justiça entender pela inadequação da sentença. A alegação dos desembargadores do Órgão Especial do TJ foi de acolhimento da tese da defesa, no sentido de que haveria contradição nas respostas dadas pelos jurados aos quesitos formulados em plenário do Júri, o que implicaria na intenção desses em absolver Ubiratan. A decisão chocou os próprios jurados que compuseram o

\footnotetext{
${ }^{84}$ É certo que as conclusões da CPI não podem deixar de refletir a heterogeneidade de seus membros, bem como suas filiações políticas e ideológicas. Como tem sido comum nas CPIs relacionadas ao tema de segurança no Estado, é recorrente os membros "linha dura", da "bancada da bala", composta por ex-policiais em geral, integrarem tais comissões, o que acaba por ser determinante aos seus rumos e desfechos, ou seja, às conclusões alcançadas. Na presente CPI, foram integrantes os deputados Conte Lopes, Edson Ferrarini e Erasmo Dias, todos eles ligados à corporação policial.

${ }^{85}$ Entre o conjunto de medidas que compuseram a denominada "Reforma do Judiciário" promovida a nível nacional, a partir do ano de 2003, está a Resolução 16 do Conselho Nacional de Justiça que passou a exigir a eleição interna ao Órgão Especial dos TJs de pelo menos metade de seus membros. Tal medida visou justamente democratizar e pluralizar a orientação jurisprudencial dos tribunais, além de buscar a ampliação do acesso à justiça. O Estado de São Paulo só passou a atender a exigência a partir de 2006, através da resolução 274/06 que imporia, entre outras, a eleição da metade dos membros do Órgão Especial. Apenas em 30 de junho de 2006 seria realizada a primeira eleição de oito integrantes deste órgão. (In: Informativo InterAÇÃO Magistratura, 2006).
} 
primeiro julgamento, inclusive aqueles que votaram pela condenação, declarando todos eles que a vontade da maioria havia sido indubitavelmente a de condenar o acusado ${ }^{86}$.

O episódio revelou de maneira ostensiva o caráter político com que a decisão foi tomada pelo Tribunal de Justiça de São Paulo, uma vez que a própria lógica do julgamento e da decisão feriu o formalismo legal tão caro aos procedimentos jurídicos. O manejo às regras jurídicas para imunizar Ubiratan se deu modo explícito, especialmente pela decisão de não submeter o acusado a novo julgamento popular, o que seria o procedimento natural nesse caso, tendo em vista a condução do primeiro julgamento ter se dado em observância às mais importantes garantias constitucionais como a ampla defesa e a todas as formalidades legais, não havendo hipótese de nulidade ${ }^{87}$.

Desse modo, decorridos quatorze anos do Massacre, nenhum dos responsáveis foi punido e, entre os processados, o mais destacado deles obteve uma decisão por um tribunal colegiado, a maior instância da justiça no estado, inocentando-o das acusações, abrindo, portanto, um importante precedente para absolvições em série dos demais envolvidos.

Para além de transmitir a clara mensagem de que o sistema de justiça brasileiro perverte os princípios democráticos da igualdade e os direitos humanos dos presos e que, garantindo a impunidade dos agentes públicos que exterminaram 111 indivíduos, também ignora os compromissos internacionais firmados pelo Estado brasileiro de fazer valer no país uma política de direitos humanos (Vivanco e Mesquita Neto, 2006), há ainda um sentido maior na absolvição do Coronel Ubiratan e na compassividade do Estado com relação a todos os envolvidos no Massacre. Esse sentido, como apontado, é a autorização da suspensão das regras jurídicas, a autorização da exceção em sua mais autêntica formulação. Vai também ao encontro de boa parte da opinião pública que vê no Massacre um instrumento legítimo para a solução da questão criminal, como apontou uma pesquisa realizada pelo jornal O Estado de S. Paulo, alguns dias após o episódio, revelando que 44\% da população da cidade apoiara a ação da polícia no episódio (Caldeira, 2003), e assim, o extermínio dos presos. O que o Estado fez a partir de então foi ratificar essa possibilidade presente no imaginário social, conformá-la e acolhê-la num universo de legitimidade.

\footnotetext{
${ }^{86}$ O Jornal Folha de S. Paulo entrevistou tanto os jurados que haviam votado pela condenação quanto os três que votaram pela absolvição quando do primeiro julgamento. In: Júri diz que decidiu sim condenar Ubiratan, Jornal Folha de S. Paulo, Caderno Cotidiano, 18 de fevereiro de 2006.

${ }^{87}$ Por 20 a 2 TJ inocenta o Coronel Ubiratan, Jornal Folha de S. Paulo. Caderno Cotidiano, 16 de fevereiro de 2006.
} 
Esse processo, que se define aqui por legitimação ou autorização do extermínio, enterra de modo ainda mais decisivo as possibilidades de politização da questão carcerária, e, ao ratificar a desconstituição precisa do sujeito de direitos e da dignidade humana dentro do cárcere, produz de modo persistente a vida nua. Nesse contexto, retomando a acepção de Rancière, o dissenso tem ainda menores chances de ser configurado e a ordem de resistências que ecoa, por exemplo, dos movimentos e organizações de direitos humanos, opera apenas como uma espécie de consciência crítica $^{88}$, não havendo como se impor, contudo, na ordem das reivindicações e, assim, no espaço da política.

\footnotetext{
${ }^{88}$ Nos estritos termos de Francisco de Oliveira em entrevista concedida ao Jornal Folha de S. Paulo (A política interna se tornou irrelevante, diz sociólogo, 24/07/2006) para se referir ao papel do PSOL no cenário político brasileiro e a função por ele desempenhada como uma espécie de grilo falante e de consciência crítica, reconhecendo, contudo, sua impotência para pautar a política nacional contemporânea.
} 


\section{O contexto de surgimento do Primeiro Comando da Capital - o PCC $^{89}$}

\section{O Centro de Readaptação Penitenciária de Taubaté, o “Piranhão”, COMO ESPAÇO PREFERENCIAL DA EXCEÇÃO}

Ao lado de uma atuação na questão penitenciária pautada pelo explícito abandono à defesa dos direitos humanos, representada essencialmente pelos episódios narrados, bem como do desinteresse em dotar os estabelecimentos prisionais quiçá de condições fisicamente viáveis para a custódia dos presos condenados e provisórios, o período ainda foi fortemente marcado pela intensificação da violência no âmbito das práticas disciplinares.

Além do emprego das “técnicas” disciplinares nunca superadas como os castigos em celas escuras e insalubres, as conhecidas masmorras e, enfim, da tortura como modalidade recorrente e cotidiana no funcionamento da prisão, a importância dessas práticas ganharia especial relevo com a criação de um estabelecimento que se notabilizaria por tal excelência disciplinar.

Em 15 de junho de 1985, ainda sob a gestão do Secretário José Carlos Dias, era criado, à revelia de qualquer formalidade, previsão legal ou regulamentar, um dos mais cruéis e obscuros presídios do sistema carcerário paulista, o Centro de Readaptação Penitenciária Anexo à Casa de Custódia de Taubaté, que se popularizaria pelo nome de

\footnotetext{
${ }^{89}$ Conforme já ressalvado na introdução deste trabalho, no que diz respeito aos acontecimentos da política penitenciária mais contemporânea, tendo em vista a escassez de estudos produzidos, bem como do caráter polêmico em que tais acontecimentos se encontram inseridos, as informações referentes foram coletadas a partir de diferentes instrumentos metodológicos, lançando-se mão não apenas da pesquisa documental que vinha até aqui sendo o principal procedimento metodológico adotado. Coletaram-se ainda depoimentos de agentes envolvidos nesse processo (governamentais e não governamentais), via de regra em entrevistas não gravadas e sem roteiro diretivo, pelas razões já explicitadas na introdução, exceção à entrevista com o exSecretário de Administração Penitenciária, Nagashi Furukawa. A consulta ao material de imprensa passa, nesse momento, a ser uma fonte privilegiada.
} 
"Piranhão" 90 . A justificar sua criação, a carência de um local onde os presos considerados “altamente perigosos” no sistema pudessem ser enviados.

A prática de segregar, de modo indistinto, presos perigosos e indisciplinados em controversos estabelecimentos, é, no entanto, mais remota na história do sistema penitenciário paulista, sendo importante resgatá-la para melhor compreender o contexto da criação do "Piranhão”. Até a década de 50, cabia ao Instituto Correcional de Ilha Anchieta cumprir essa função de estabelecimento de “excelência disciplinar” dentro do sistema, recebendo em regime de isolamento (intensificado pela sua localização) os presos considerados “problemáticos”. Em 1952, uma violenta rebelião levaria à morte de presos e funcionários, bem como à destruição de grande parte das instalações do presídio, trazendo a público a crise e a tensão vivenciadas naquele tipo de estabelecimento, há décadas. Três anos depois, já em 1955, esse presídio seria finalmente desativado, sob o governo de Jânio Quadros (Adorno e Fisher, 1987).

No mesmo ano, inaugurar-se-ia a Casa de Custódia e Tratamento de Taubaté, local destinado ao cumprimento de medidas de segurança aplicadas, segundo o Código de 1940, aos "loucos criminosos" e àqueles portadores de periculosidade. Ocorre que, desde sua instalação (e até a criação do Anexo) era dada também outra destinação a esse Manicômio, embora não prevista em lei: o recolhimento de presos com "problemas de indisciplina” (CPI Sistema Prisional, 2001). Além disso, a Casa de Custódia notabilizar-se-ia ainda pelo tratamento truculento dispensado indistintamente aos inimputáveis, semi-imputáveis, indisciplinados e até aos menores de dezoito anos, também irregularmente lá detidos, através de um regime de intenso isolamento, escassos banho de sol e severos castigos num sistema de “cela-forte” (Pinheiro e Braun, 1986).

O fato de referido local operar, ainda sob a vigência do Código Penal de 1940, indistintamente como manicômio e presídio para "indisciplinados", nunca chegou a gerar oposições no plano formal, justamente em razão da inexistência de disposições legais que regulamentassem a questão disciplinar. Desse modo, embora ausente qualquer autorização legal a tal rotina não autorizasse, não se encontrava no ordenamento vedação expressa a tais arranjos, embora evidente sua inadequabilidade. No mesmo sentido, o fato de ingressarem imputáveis num estabelecimento como um Manicômio Judiciário também não

${ }^{90}$ A origem do nome é atribuída ao fato de que o presídio recebera, desde sua criação, os criminosos mais perigosos do Estado, conhecidos como "piranhas", daí "Piranhão" (Revista Caros Amigos, Edição Extra PCC, maio de 2006). 
causava tanta estranheza em razão da vigência de um sistema (o duplo binário) que permitia a aplicação da medida de segurança também aos imputáveis (desde que portadores de periculosidade na acepção do Código de 1940) cumulativamente à prisão.

Após a entrada em vigor do novo Código e da LEP em 1985, essa situação não pôde persistir do ponto de vista legal, por duas razões. A primeira, e em verdade a única realmente levada em conta, referiu-se à mudança no sistema de aplicação da medida de segurança e a vedação de sua imposição aos imputáveis. A outra diz respeito ao fato da LEP ter colocado os procedimentos disciplinares dentro de uma previsão legal, conforme já tematizado no segundo capítulo, pelo que se passaria a impedir a remoção indiscriminada e por tempo indeterminado de presos indisciplinados. Como já se apontou, contudo, essa prescrição legal continuou a ser totalmente ignorada no plano do funcionamento do modelo disciplinar pela administração penitenciária, até a reforma da LEP em 2003 que a derrogou em parte para instituir o RDD - regime disciplinar diferenciado.

Por outro lado, São Paulo, assim como os demais Estados da federação, já se ressentia da inexistência de penitenciárias de segurança máxima, o que ocorre ainda hoje ${ }^{91}$, não obstante a disposição da LEP no sentido de que o sistema prisional devesse ser dotado de estabelecimentos de alta, média e baixa segurança, cabendo primordialmente à União, mão não somente a ela, a administração dos primeiros ${ }^{92}$.

O Centro de Readaptação Penitenciária, Anexo de Taubaté, foi criado, contudo, não como um presídio de segurança máxima, muito embora essa tenha sido sua declarada motivação, mas para atender às mesmas finalidades disciplinares que eram executadas no sistema anterior à reforma do Código Penal - a punição de indisciplinados - e segundo os mesmos procedimentos, com a única de diferença que criava para isso um estabelecimento próprio que não mais um Manicômio Judiciário ${ }^{93}$. Isso porque, como afirmou seu principal diretor, José Ismael Pedrosa, à CPI do Sistema Prisional (2001), o Anexo foi inaugurado

\footnotetext{
91 Apenas em data recente, em 23/06/2006, seria finalmente inaugurada a primeira penitenciária federal de segurança máxima em Catanduvas/PR. Segundo o órgão oficial responsável por sua concepção e inauguração, ela conta com sofisticada estrutura física e humana: aparelhos de RX, detector de metais, monitoramento de câmeras 24hs conectadas à Polícia Federal e ao Departamento Penitenciário Nacional, celas individuais com acomodações a princípio adequadas, e um regime de isolamento quase permanente ao preso. (In: Ministério inaugura primeira penitenciária federal no país, Agência Folha de Notícias, www.folhadesaopaulo.com.br/agenciafolha acesso em 23/06/06).

92 Conforme previsto na LEP, art. 86, parágrafo $2^{\circ}$.

93 Nos fundos da Casa de Custódia de Taubaté havia um esqueleto de prédio, uma construção inacabada para uma unidade de recolhimento de menores. Teria sido esse esqueleto então que fora aproveitado para a instalação do Anexo.
} 
com o propósito de receber desde os presos de “altíssima periculosidade” até aqueles com “problemas de indisciplina”.

A junção entre requisitos diversos (a "periculosidade" advinda do perfil do criminoso e o cometimento de faltas disciplinares no âmbito da prisão), traduziu e ainda traduz a indistinção em que essas duas questões - a segurança e a disciplina - vêm sendo tratadas no âmbito da administração prisional e da formulação de políticas para o cárcere. Tal combinação e ainda o tratamento único dispensado a elas podem ser compreendidos como fatores de forte determinação à atual crise do sistema carcerário, na qual nunca a idéia de segurança e controle sobre a massa carcerária esteve tão afetada, não obstante os mecanismos de disciplina terem permanecido operantes e ainda sido intensificados ${ }^{94}$.

Presídios com diferentes graus de segurança são previstos em grande parte dos sistemas penitenciários no mundo, decorrente tal previsão em escala direta do princípio da individualização da pena. Ou seja, ainda que tal princípio seja adotado com maior ou menor intensidade pelo aparato repressivo de cada Estado, é certo que a separação de indivíduos condenados segundo as características dos crimes cometidos, seu grau de envolvimento em organizações criminosas e a pena imposta tem sido um critério norteador adotado de modo até então uniforme.

A penitenciária de segurança máxima seria em tese o local onde a vigilância mostrar-se-ia mais intensa e, por conseqüência, dinâmicas no cumprimento da pena sofreriam impactos no que diz respeito, por exemplo, ao recebimento de visitas e até ao desempenho de atividades cotidianas. No mesmo sentido, seria destinada a acolher presos em caráter não transitório, ou seja, não deveria ser concebida como uma "grande cela de castigo”, mas sim como o local definitivo de cumprimento de pena.

A idéia, entretanto, de conceber um presídio de segurança máxima ainda como um local destinado ao cumprimento de sanções disciplinares aplicadas a quaisquer presos, ou seja, como um local para execução de castigos dentro do sistema, subverte em si a lógica que justificaria sua existência, criando em verdade, um espaço no qual se reproduzem

\footnotetext{
94 Como será discutido adiante, a criação do Regime Disciplinar Diferenciado (o polêmico RDD) pelo governo de São Paulo em 2001 e sua posterior incorporação a nível nacional como dispositivo de lei (pela reforma da LEP em 2003), acentuou essa indistinção ao continuar tratando o problema da segurança através de dispositivos disciplinares (necessariamente temporários) ao invés do investimento em presídios de segurança máxima.
} 
domínios a partir dos quais o poder disciplinar incide de modo cada vez mais contundente, e com ele sua representação implícita do contradireito e do arbítrio.

Não por acaso, o arbítrio tem estado presente na constituição desses híbridos locais, como foi o caso do contexto de criação do Centro de Readaptação Penitenciária de Taubaté, o “Piranhão”. Inaugurado à revelia de qualquer instrumento legal ou administrativo que previsse e regulamentasse sua existência e destinação, não obstante estar-se em pleno período de redemocratização no país e já sob a égide de uma legislação penal amplamente garantista, o Anexo de Taubaté manteve seu funcionamento, ao longo dos anos, de modo obscuro, indeterminado e incontestado, conservando até hoje seu caráter de inevitabilidade.

Dois anos após sua inauguração, uma resolução da Secretaria de Justiça, responsável à época pela administração penitenciária, formalizaria então a existência do “Piranhão”. A Resolução de no 12 de 04/05/87 passaria a oficializar a destinação que já vinha sendo dada ao Anexo, ou seja, o recolhimento de presos de alta periculosidade e com faltas disciplinares graves. Nenhuma outra especificação seria dada com relação, por exemplo, ao procedimento para o ingresso, o tempo de permanência, as restrições de direitos e o regime de internação no local, em clara afronta ao conteúdo da LEP recémeditada, que previa a sanção disciplinar máxima para faltas graves de 30 dias de isolamento na própria cela ${ }^{95}$.

Em 1993, uma nova resolução seria editada pela então recém-instituída Secretaria de Administração Penitenciária (Resolução SAP nº 78 de 26/08/93), com a finalidade de oferecer maior detalhamento quanto às hipóteses de "inclusão" no "regime" do Centro de Readaptação de Taubaté. No entanto, a nova resolução, ao mesmo tempo em que estabelecia disposições mais objetivas - especificando, por exemplo, os tipos de faltas e o tempo de recolhimento - utilizava outras previsões para anulá-las, operando assim através da exceção que corrói a regra instituída.

Desse modo, embora a Resolução precisasse o tempo de permanência (6 meses a 2 anos) e os tipos de faltas que ensejariam a remoção ao Anexo - fugas com reféns, lesões corporais cometidas contra funcionários, homicídios e participação ativa em rebeliões -

\footnotetext{
${ }^{95}$ Como dispunha a Lei de Execução Penal de 1984 (Lei 7210/84), em seu art. 85, revogado pela Lei
} 10.792/03 que reformaria parcialmente a LEP. 
permeando o texto encontravam-se as hipóteses extraordinárias a derrogar uma a uma as disposições da regra.

Primeiro, a também inclusão dos "sentenciados de alta periculosidade", que seriam assim definidos pelas autoridades competentes - o Secretário de Administração Penitenciária, o Coordenador dos Presídios e o Juiz Corregedor - ausente qualquer outro elemento fático ou objetivo que pudesse definir a periculosidade apresentada por tais indivíduos. Segundo, para esses casos de alta periculosidade, prazo indeterminado de internação, leia-se isolamento, pois lá eram mantidos isolados. Terceiro, a existência de tempo indeterminado, enfim, para todos os presos para lá removidos, mediante um dispositivo (parágrafo único do art. $5^{\circ}$ da Resolução) que por si anulava a previsão anterior quanto ao limite de permanência: a prorrogação por seis meses, sem limite de repetição, sempre que as autoridades, nesse caso só as do Executivo, assim o determinassem a partir de requerimento do diretor do estabelecimento.

Vê-se assim que não obstante a LEP ter penetrado o obscuro campo da existência disciplinar e adentrado com as regras do direito num universo onde a norma sempre prevaleceu, tal previsão resultou em mais um dispositivo inoperante, pervertido de modo explícito pelo Estado. Ou seja, primeiro a existência fática do Anexo de Taubaté e depois sua destinação (prevista de modo regulamentar) em colidência direta com a legislação vigente, transmitiram uma clara mensagem do Estado penal brasileiro, de que o campo da lei não adentraria o da disciplina, o da norma, ainda que para isso se optasse pela incontestada ilegalidade, através dos dispositivos da exceção. É de se registrar que essa “opção” da Administração Penitenciária jamais encontrou no Poder Judiciário, guardião da lei e do Estado de direito, um pronunciamento sobre sua ilegalidade, em nenhum aspecto, nem no mais elementar que se referia ao da afronta aos procedimentos disciplinares previstos na LEP, que prescreviam a ampla defesa e a sanção máxima de 30 dias de isolamento na própria cela do preso.

Em meio à exceção instalada, o "Piranhão" se consolidaria como um dos mais cruéis estabelecimentos carcerários do Estado. Os poucos relatos que se colheram ao longo dos anos dão conta da truculência do tratamento dispensado no local, não apenas pelas restrições impostas (isolamento absoluto por 23 horas, visitas, higiene, etc) como pela violência expressa por meio de cotidianos espancamentos - muitos deles com barras de 
ferro $^{96}$-, variados expedientes de tortura física e psicológica e um severo regime de isolamento, rompido por escassas horas de sol semanais ${ }^{97}$. Soma-se a isso a indeterminação do tempo de internação e a uma realidade de quase incomunicabilidade com o mundo exterior, diante essencialmente das dificuldades colocadas ao contato com advogados e familiares, e se pode ter, então, a dimensão do tratamento cruel conferido no local, a temibilidade gerada entre os detentos e a alcunha que lhe atribuíram, "Fábrica de Monstros”.

Algumas particularidades quanto à estrutura e ao funcionamento do Anexo expressavam uma rotina de violência institucional bastante peculiar: a promoção de tortura física cotidianamente por vários agentes ${ }^{98}$, a existência de vaso sanitário na cela sem o dispositivo de descarga, que só poderia ser acionado pelo agente penitenciário do lado de fora, assim como a luz (e, diga-se de passagem, são ainda hoje celas em sua maioria escuras). Segundo relatos ${ }^{99}$, o acúmulo de dejetos nas celas podia durar dias, estabelecendo no local uma situação tal que se misturavam indistintamente à comida servida, muitas vezes com insetos vivos, num cenário que muito se assemelha aos horrores vividos por sobreviventes de campos de concentração e gulags ${ }^{100}$.

\footnotetext{
${ }^{96}$ Além das informações prestadas por Ana Maria Olivatto à CPI Sistema Prisional (2001) dando conta de tais espancamentos, em entrevista à Revista Caros Amigos (edição extra PCC, maio de 2006), o promotor de justiça Marcio Christino relatou que, em razão dos espancamentos com barras de ferro, "Geleião", um dos fundadores do PCC, apresentaria hoje sérias lesões no cérebro. No mesmo sentido, depoimento para este estudo da advogada Adriana Nunes Martonelli, integrante da Comissão de Direitos Humanos da OAB/SP em 1992, ano em que foi instaurado procedimento para apurar denúncias sobre promoção de tortura no "Piranhão".

${ }^{97}$ Embora inexistente disposição regulamentar a respeito do regime de isolamento e de contato com outros presos no Anexo de Taubaté, todos os depoimentos levantados, inclusive o do próprio diretor, dão conta que se tratava de um regime de 23 horas de isolamento e banho de sol em grupos de 7 a 10 presos por menos de uma hora. Apenas nesse breve período, os presos podiam comunicar-se entre si (CPI Sistema Prisional 2001). Jesus Aparecido Joaquim Oliveira, um ex-detento que foi mantido dois anos no regime de isolamento de Taubaté, em entrevista concedida em 10/11/1999 à Comissão Teotônio Vilela - CTV, relatou ainda que os presos improvisavam formas de comunicação, através das frestas inferiores das portas e pelas janelas, na tentativa de romper o isolamento e a completa ociosidade.

98 Jesus forneceu relatos à CTV sobre a rotina de espancamentos diários sofridos no "Piranhão", que se iniciavam logo pela manhã, quando a cela era aberta para entrega de alimentos. Com o tempo, os presos passavam a se precaver e não colocar o rosto para fora, na tentativa de escapar desse primeiro golpe (CTV, 10/11/1999).

${ }^{99}$ CPI do Sistema Prisional, 2001 e Revista Caros Amigos, Edição Extra, PCC, maio de 2006.

100 Goffman fornece exemplos de notável semelhança a partir de relatos de ex-prisioneiros desses tipos de estabelecimentos. No que ele chama de tipo mais evidente de exposição contaminadora relata a imposição aos presos de realização de defecção somente uma vez ao dia no horário determinado pelos guardas e na sua presença, durante escassos minutos; o oferecimento de alimentos sujos e contaminados e a exigência do banho também por escassos minutos e em locais de acentuada sujeira e insalubridade (Goffman, 1996: 3235). Sobre o exemplo do banho, bem como das diferentes disposições de aniquilação do eu e de perda da
} 
Essas milimétricas e cotidianas operações, com maior ou menor brutalidade, operam todas na intensificação daquilo que Goffman (1996) atribuiu como mortificação do $e u$, processo que, embora inerente à existência institucional, apresenta dimensões que variam de acordo ao grau de intencionalidade voltado à degradação do indivíduo, o que é identificado em experiências históricas precisas como nos já mencionados campos de concentração em regimes totalitários.

A imposição do regime de intenso isolamento e a submissão a torturas sistemáticas também provocavam, segundo relatos inclusive de diretores de outras unidades prisionais, a promoção de atos desesperados pelos internos, freqüentemente atribuídos como suicídio. Era o caso do fogo ateado pelos próprios presos em suas celas, o que os levava à morte por asfixia ou pelas lesões decorrentes das queimaduras, uma vez que era também uma prática adotada pelos agentes não proceder à abertura das celas ou ainda postergar ao máximo a retirada do preso do local ${ }^{101}$, o que ocasionava, no mínimo, graves ferimentos.

O mais destacado diretor do Anexo, Ismael Pedrosa ${ }^{102}$, foi um homem de histórico institucional bastante controverso, tendo ocupado anteriormente o cargo de diretor de disciplina da Casa de Custódia de Taubaté (Manicômio Judiciário) durante anos, sendo tido desde àquele tempo como um diretor "linha dura", responsável por uma política que traduzia o Manicômio como um local bastante cruel para a internação de inimputáveis e ainda àquele tempo dos perigosos e jovens adultos (Pinheiro e Braun, 1986). Tornou-se diretor de Anexo após sua inauguração e sempre foi a figura mais destacada na existência do “Piranhão”, sendo especialmente odiado pelos presidiários lá confinados, segundo relato daqueles que chegaram a denunciar Taubaté, inclusive os fundadores e líderes do PCC, mas não apenas eles ${ }^{103}$.

condição humana, o testemunho de Primo Lèvi (1988) sobre os horrores vividos num campo de concentração nazista, também é bastante representativo.

${ }^{101}$ Nesse mesmo sentido, o depoimento de Jesus à CTV, relatando uma oportunidade em que um agente teria salvo o preso abrindo a cela a tempo, o que provocou sua punição pela direção do Anexo e posterior transferência. Maria Emília Guerra Ferreira, enquanto exerceu a direção do Hospital Central do Sistema Penitenciário (1997 a 2000), um estabelecimento que atendia pacientes HIV+ em estágio avançado, relatou, em entrevista realizada em 23/08/2006 para esse estudo, que recebera em algumas oportunidades presos oriundos do "Piranhão" com graves lesões e queimaduras, em função de terem ateado fogo em suas celas.

${ }^{102}$ Um fato curioso a respeito de Ismael Pedrosa é que embora durante quase toda sua carreira no sistema penitenciário tenha atuado como agente e diretor da Casa de Custódia e do Anexo de Taubaté (o "Piranhão”), exerceu em duas oportunidades a direção da Casa de Detenção do Carandiru, uma delas justamente durante o Massacre em 1992.

${ }^{103}$ CPI do Sistema Prisional, 2001. 
As acusações contra o diretor referiam-se, em grande parte, ao fato de ser ele não apenas conivente, como o grande responsável pelas práticas reiteradas de tortura e violência no local. Não por acaso, na megarrebelião de 2001, as principais exigências apresentadas pelo PCC seriam o afastamento de Pedrosa e a desativação do "Piranhão", sendo certo, contudo, que o governo não atenderia a nenhuma delas. Em outubro de 2005, Pedrosa seria assassinado com diversos tiros em Taubaté, não havendo conclusão sobre a autoria e os motivos do crime até então, apenas suspeitas que naturalmente recaem sobre os membros do PCC.

Como já afirmado, a existência do Anexo sempre esteve garantida ou ainda legitimada, diante do que se pode chamar de sua inevitabilidade. Ou seja, desde sua criação, reuniu-se um certo consenso em torno dessa necessidade, o que levou o então Secretário José Carlos Dias, representante da política humanizadora nas prisões, à inauguração do Anexo de Taubaté, por mais paradoxal que esse ato pudesse parecer. O argumento em torno desse “consenso” repousava na necessidade de criação de um local destinado a funcionar como presídio de segurança máxima no Estado e, diante de tal necessidade, pouco se questionou sobre o desvirtuamento das finalidades, já praticado desde sua gênese e agravado em sua operacionalização.

A inevitabilidade da existência do "Piranhão" foi assim sempre sua marca, bem como foi o código a partir do qual se garantiria sua “imunidade” às denúncias, representações e até procedimentos correcionais. Curiosamente, o Anexo de Taubaté não foi, ao longo dos anos de sua existência como centro de "excelência disciplinar”, alvo preferencial de denúncias ou de investigações ${ }^{104}$, muito embora a rigidez que o blindasse já fosse em si indicativa da suspeição que deveria recair sobre seu funcionamento. A escassez de documentos disponíveis encontrados a respeito de visitas, representações, denúncias ou

\footnotetext{
104 Após insistentes buscas, cheguei ao registro de apenas uma série de incidentes formalizados contra as práticas adotadas no "Piranhão". Resultaram de uma visita realizada ao local, no início da década de 90, pela Comissão de Direitos Humanos da OAB/SP e pelo deputado federal Elói Pietá do PT, em virtude de denúncias oriundas de familiares de presos. A visita teria ensejado a instauração de um procedimento na OAB/SP, cuja conclusão fora encaminhada à SAP e ao Ministério Público. A Corregedoria da SAP teria, em decorrência, aberto uma sindicância para apurar as denúncias e as devidas responsabilidades dos agentes envolvidos, que, após tramitar alguns anos, foi arquivado sem qualquer condenação de seus acusados. Com relação a procedimentos judiciais, não foi possível localizar qualquer processo que tivesse sido instaurado na Justiça com relação aos acusados pelo crime de tortura, muito embora o procedimento da OAB estivesse instruído com fartos laudos e depoimentos, segundo a advogada Adriana Nunes Martonelli, membro da Comissão à época. O procedimento originário da OAB, embora tivesse sido arquivado na entidade, não foi localizado para consulta. Após semanas de busca, a meu pedido e da advogada citada, o procedimento foi dado como extraviado pelos funcionários da Comissão de Direito Humanos encarregados do arquivo de tais documentos.
} 
mesmo relatos sobre o local por parte dos organismos de direitos humanos mais destacados na área, dão conta desse paradoxo em torno de seu funcionamento, bem como da "eficácia" de seu ocultamento. Mesmo o órgão encarregado pela Defensoria Pública à época, a Procuradoria de Assistência Judiciária, teria em poucas oportunidades formulado representações aos órgãos competentes sobre os abusos cometidos no Anexo, procedimento diverso do que passaria a ser adotado a partir de 2001, quando outros estabelecimentos seriam criados com as mesmas finalidades do "Piranhão", mas segundo outras regras e outra lógica informadora.

É certo que, a existência desses locais estabelece de modo ostensivo as chamadas zonas de exceção, nas quais não só a exceção é integralmente convertida em regra, como a ambivalência e omissão dessas novas "regras de exceção” e de suspensão de direitos acabam por operar como garantes ao ocultamento de seu funcionamento e, enfim, de sua existência.

\section{SOMOS FORTES ONDE O INIMIGO É FRACO ${ }^{105}$}

Esse foi, portanto, o contexto em que o Primeiro Comando da Capital, o PCC, a mais importante organização criminosa atuante nos presídios brasileiros, teria então surgido. As informações sobre seu nascimento, em maioria advindas da imprensa, remetem-se a uma fonte mais ou menos comum: o depoimento dos próprios fundadores, integrantes da organização e seus parentes ${ }^{106}$. As autoridades, quando se manifestam a respeito, não trazem dados muito esclarecedores, talvez em função da própria “estratégia” que o governo estadual adotou durante anos em negar o PCC (CPI Sistema Prisional, 2001;

105 Declaração feita por um dos fundadores do PCC, em entrevista concedida por telefone ao Jornal Folha de S. Paulo, de dentro de um presídio, dias após a megarrebelião de 2001. PCC ameaça governo com atos terroristas. In: Jornal Folha de S. Paulo, Caderno Cotidiano, 02/03/2001.

${ }^{106}$ Os relatos sobre a origem do PCC foram extraídos de três principais fontes. A primeira é o depoimento de um de seus fundadores, o "Geleião”, que sob delação premiada teria fornecido elementos detalhados sobre a formação do PCC ao GAECO - Grupo de Atuação Especializada e Repressão ao Crime Organizado do Ministério Público. Um dos promotores responsáveis pelas investigações, Márcio Christino, forneceu, em entrevista à Revista Caros Amigos (Edição Extra PCC, maio de 2006) as informações sobre o depoimento de “Geleião". A segunda fonte se refere às informações integrantes da entrevista concedida por um dos líderes da Organização, por telefone, ao Jornal Folha de S. Paulo (PCC ameaça governo com atos terroristas Caderno Cotidiano, 02/03/2001). Por fim, em depoimento à CPI do Sistema Prisional, em 30/08/2001, Ana Maria Olivatto, ex-esposa de "Marcola”, hoje apontado como o principal líder do PCC, narrou fatos importantes à recomposição da história do PCC e também em relação às condições de encarceramento do Anexo de Taubaté, quando interrogada pelos deputados integrantes da CPI Sistema Prisional, 2001. 
Martins, 2004) ${ }^{107}$, até que a megarrebelião de 18 de fevereiro de 2001 deflagrou amplamente sua existência.

Segundo o conjunto de informações que dão conta, portanto, da origem do PCC, o Anexo de Taubaté é descrito como o local em que seus fundadores, em agosto de 1993, teriam selado o “pacto” de sua fundação, cuja diretriz maior seria a melhoria das condições carcerárias através de uma guerra contra os principais responsáveis pelas torturas e os maus tratos no sistema, em especial contra o local que eles denominaram como "o campo de concentração de Taubaté”. Os objetivos firmados e as regras de "convivência” do grupo estariam prescritos e assegurados a partir de um rígido código disciplinar cuja sanção aplicada ao descumprimento seria comumente a morte.

É certo que as disposições previstas em seu estatuto apontam a um conteúdo manifestamente “político” expresso pela contundente denúncia da violência do sistema carcerário representada especialmente nas torturas do Anexo de Taubaté e no Massacre do Carandiru, textualmente citados. No entanto, a divulgação de referido "manifesto”, assim como dos episódios que marcaram sua origem e a ritualização que a acompanha, devem ser analisados dentro dos limites que elas próprias anunciam.

Ou seja, não é sustentável a crença de que houvesse ou que ainda hoje haja, motivando a atuação do PCC, um compromisso de luta e denúncia contra a "opressão carcerária”, para usar os termos da Organização. Isso porque, tanto as finalidades como o modus operandi da facção revelam outros significados: a promoção de atividades criminosas dentro e fora do sistema com o objetivo do lucro e enriquecimento de seus membros, a expansão e consolidação de seu poder nos presídios, conseguida a custa de uma “adesão” nem sempre voluntária por parte dos presos, assumindo assim, em muitos casos, a dimensão opressora sobre a mesma massa carcerária em nome da qual o PCC se comprometeria a libertar.

\footnotetext{
${ }^{107}$ Nas sessões dessa CPI, em algumas oportunidades o deputado Afanasio Jazadi fez menção à CPI Sobre o Crime Organizado, instalada em 1997, na qual as informações sobre o PCC teriam sido anteriormente levantadas, tendo referido deputado inclusive lido o Estatuto da Organização em sessão, razão pela qual se encontra publicado no D.O.E. de 20/05/1997. Afirmaou ainda que, naquela época, o então Secretário de Administração Penitenciária, João Benedito de Azevedo Marques, fora depor na CPI e negara a existência do PCC ou de qualquer outra organização criminosa atuante nos presídios, desdenhando ainda as investigações. Já em 2001, quando o Secretário Nagashi seria então questionado sobre a atitude de seu antecessor, teria afirmado que essa postura traduzira uma estratégia política adotada pelo anterior Secretário, com o fim de não fortalecer tais organizações (CPI Sistema Prisional, 2001). No mesmo sentido, depoimento de Nagashi prestado em entrevista realizada em 31/08/2006 para este estudo.
} 
Isso não significa dizer, no entanto, que as condições de encarceramento representadas não somente pela existência do "Piranhão", mas de um modo geral por toda a lógica na qual o sistema se operacionaliza, não teriam contribuído de modo importante para a formação de organizações criminosas como o PCC dentro dos presídios.

Assim, a necessidade que se coloca é antes a de contextualizar o processo a partir do qual teria se originado o PCC, identificando as práticas e orientações, e, enfim, a diretriz política que o sistema vinha adotando e que contribuíram na formação dessa e de outras organizações criminosas no cárcere ${ }^{108}$. Num segundo momento, o que se também destaca é a impossibilidade de conferir um caráter de representação e legitimidade à alegada defesa de direitos dos presos que tal organização se atribui, diante do anacronismo entre a ordem de seu discurso e de suas práticas.

Voltando à gênese do PCC, não se nega ainda que uma determinada configuração teria sido propícia para que sentimentos comuns por parte dos presos fossem mobilizados e uma certa idéia de coesão surgisse e fosse fortalecida até pela adversidade enfrentada. Sem adentrar de modo mais profundo nas discussões teóricas acerca da complexa teia de interações que dizem respeito aos processos organizacionais, que não é a proposta do presente estudo, é possível, contudo, identificar na existência desses grupos dentro das prisões importantes derivações dos ajustamentos secundários que constituem também formas de reorganizações do eu por parte dos internos nas instituições totais (Goffman, 1996).

Ainda segundo Goffman, esse processo de confraternização se expressaria nas formas de apoio mútuo e resistência desenvolvidas pelos internos, bem como no desenvolvimento de um sentimento de injustiça comum (Goffman, 1996:55-56), todos eles fundamentais na gênese desses agrupamentos. A sujeição ainda a castigos demasiadamente cruéis tenderia a intensificar a mobilização desses sentimentos de amargura para com o mundo exterior propiciando mais fortemente o desenvolvimento de laços (e expectativas de laços) de lealdade entre os presos, o que contribui na explicação da formação de grupos e facções dentro dessas instituições.

\footnotetext{
${ }^{108}$ Em depoimento prestado à CPI do Sistema Prisional em 2001, o próprio Secretário de Administração Penitenciária, Nagashi Furukawa, teria elencado as organizações criminosas existentes nos presídios naquele momento, referindo-se a atuações setorizadas por estabelecimento carcerário, na maioria delas. Hoje, contudo, em razão da expansão e do fortalecimento do PCC, grande parte de tais organizações se encontram extintas.
} 
Essa é uma configuração que distingue o processo de formação do PCC, por exemplo, dos modelos tradicionais de facções e de gangues que atuam via de regra em presídios. G. M. Sykes (1994), em seu emblemático estudo numa penitenciária de segurança máxima norte-americana (The Society of Captives, publicação original de 1958) descreve a existência de agrupamentos e facções de gorillas - como são designados aqueles que se impõem à massa pela força ou pela ameaça da violência. Sykes levantou registros, a partir de um estudo pioneiro realizado nessa penitenciária no ano de 1830, que denunciavam a existência de uma dessas facções, denominada Stauch-Gang, que operava intimidando guardas, coagindo prisioneiros e na promoção de numerosos planos de fuga. $\mathrm{O}$ autor observa, contudo, que a existência dessas organizações de presos violentos com a finalidade de extorsão e fuga estaria em grande desuso já no momento de sua pesquisa (1958), em razão da própria natureza e dos objetivos que determinam a carreira moral desse tipo de prisioneiro (gorilla), fazendo com que sua atuação acabe sendo individual, não ensejando ainda a formação de laços de lealdade a partir de eventuais interesses comuns que pudessem uni-los (Sykes, 1994:92).

Além, portanto, dos sentimentos comuns de injustiça e das adversidades enfrentadas que teriam influído no processo de mobilização e coesão entre os fundadores do PCC, alguns outros fatores devem ser considerados na compreensão do fenômeno de formação dessa Organização, como a constatada heterogeneidade das unidades prisionais do sistema penitenciário paulista. Como um mosaico construído segundo finalidades não evidentes, o sistema mantinha, ao lado da rigidez expressa pelo regime de cela forte do Anexo de Taubaté, estabelecimentos sobre os quais o Estado não exercia qualquer espécie de controle formal, sendo a Casa de Detenção do Carandiru o exemplo mais eloqüente.

A Casa de Detenção, que abrigava no período uma população em torno de 7.000 presos, não obstante contasse com uma capacidade para menos da metade desse contingente, foi o símbolo máximo de uma política penitenciária que endossava a corrupção, a violência, o arbítrio, e que atestava a incapacidade do Estado em lidar com a questão carcerária dentro dos padrões da legalidade, racionalidade e da preservação de direitos.

A própria concepção arquitetônica do presídio, com celas em coletivo concebidas para abrigar um número expressivo de presos, a multiplicidade de pavilhões, a precariedade e o improviso de serviços essenciais, enfim, tudo favorecia a realidade que se 
desenhou na Casa de Detenção: a promiscuidade nas celas, a ociosidade inevitável a que os presos eram submetidos e o controle da cadeia pelos próprios detentos (Ramalho, 2002; Salla, 2000). Com o tempo, essa realidade passou a ser absolutamente definidora da dinâmica de seu funcionamento e cada vez mais determinante no modo pelo qual as relações entre presos e funcionários estabeleciam-se e se operava a distribuição de poder no interior do sistema ${ }^{109}$.

De outro lado, convém lembrar que o "Piranhão” operava (como ainda hoje opera, só que reformuladamente) como local para execução de castigos (sanções disciplinares) de modo temporário, ao cumprimento de uma espécie de contenção transitória, o que implicava na "devolução" do preso ao sistema penitenciário, ainda que até esse retorno transcorressem alguns anos.

Advieram daí, a princípio, dois importantes fatores que são atribuídos como centrais à formação do PCC: em primeiro lugar, a oportunidade ofertada para que os criminosos mais "perigosos" e em tese mais "sofisticados" fossem reunidos em um mesmo estabelecimento. Em segundo lugar, sua posterior dispersão pelo sistema em locais tais como a Casa de Detenção, de modo que seu espectro de atuação e seu poder de mobilização puderam ser multiplicados.

Se tais fatores ajudam a compreender o processo pelo qual as organizações criminosas se formam e se expandem nas prisões brasileiras, tal como ocorreu em estritos termos com o Comando Vermelho a partir do Presídio de Ilha Grande/RJ, não são suficientes, contudo, para elucidar aquilo que o PCC apresenta como diferencial: seu poder de unificação da maior massa carcerária do país, não apenas sob o signo da violência e da coação, mas principalmente na ocupação de um espaço e no desempenho de funções que seriam pertinentes ao Estado, dentro das prisões. Ou seja, o PCC ao conseguir instalar com êxito novos códigos de convivência e um novo conjunto de regras dentro da existência prisional, recriou em verdade uma nova ordem, a qual, ao

\footnotetext{
109 A Casa de Detenção da Capital, apesar de toda a sua precariedade, era “amada” por grande parte da população carcerária. Em entrevista que realizei junto ao Ouvidor da Administração Penitenciária, Pedro Armando Egydio Carvalho, um procurador do estado aposentado que atuou durante mais de vinte anos na assistência judiciária na área de execução penal, afirmou que os presos solicitavam muitas vezes para permanecerem na Detenção ao invés de serem transferidos a outros estabelecimentos com celas individuais e com trabalho, uma vez que o grau de liberdade existente naquele lugar seria inigualável (entrevista realizada em 09/08/2006).
} 
menos num primeiro e importante momento, os presos assentiram em busca de proteção e sobrevivência $^{110}$.

Desse modo, é possível afirmar que foram a ausência e a insidiosa presença do Estado nos presídios (representadas fundamentalmente na corrupção e na truculência de suas gestões), bem como a exarcebação da violência e da tortura em estabelecimentos de excelência disciplinar como o Anexo de Taubaté, os principais elementos que não apenas estiveram na base do fenômeno que originou o PCC, mas que garantiram sua expansão e seu fortalecimento. É nesse sentido que é possível interpretar a expressão cunhada pela Organização: somos fortes onde o inimigo é fraco. A fraqueza aí descrita é aquela que provém de duas situações que caracterizam de modo peculiar o sistema penitenciário brasileiro: a primeira se manifesta na mais completa ausência do Estado dentro das prisões, sintetizada pelo abandono das responsabilidades referentes à custódia de indivíduos que o poder de punir lhe atribui e das formas escandalosas de corrupção e de “delegação da administração prisional” a partir de acordos e negociações espúrias entre seus representantes e grupos de presos ${ }^{111}$. A segunda manifestação pode ser descrita na falta de legitimidade da atuação do Estado, expressa especialmente através do uso ilegítimo da força. Em ambos os casos, o que se verifica é o abandono às premissas de um Estado de direito, sendo justamente tal abandono o que confere ao Estado sua vulnerabilidade, tornando-o um inimigo facilmente derrotável.

O fato ainda de o Estado ter reagido bastante tardiamente à existência do PCC e a partir dos mesmos mecanismos (disciplinares) que já utilizava para a repressão no interior do sistema, sem um devido aparelhamento que se traduziria essencialmente em serviços de inteligência e maior vigilância a esses indivíduos (o que não implica necessariamente em expedientes de tortura como forma de castigo) são também fatores que contribuíram de

\footnotetext{
${ }^{110}$ Não por acaso, alguns presos e agentes de entidades atuantes nos presídios creditam a diminuição dos crimes sexuais e da violência dentro das prisões ao período em que o PCC passa a expandir seu poder entre as unidades (nesse sentido depoimento de José Jesus Filho, agente da Pastoral Carcerária, colhido para este estudo em 05/09/2006 e Revista Caros Amigos, Edição Extra, maio de 2006.) É certo, contudo, que se tratam de percepções dos atores envolvidos, e, embora elementos portadores de grande relevância, carecem do cotejo aos dados oficiais e estudos realizados dentro dos próprios presídios no sentido de testar as hipóteses que anunciam.

${ }^{111}$ Embora marcantes e acentuados no sistema penitenciário brasileiro, tais "vícios" de atuação não são exclusivos a ele. Sykes identifica também tais procedimentos - corrupção de oficiais, transferência aos presos de tarefas que a eles incumbiriam, ausência do sentido de responsabilidade no desempenho de suas funções e as transgressões dos presos diante da patética coleção de castigos e recompensas que induz à subversão dos regulamentos - como defeitos estruturais no sistema de poder das prisões ao invés de inadequações individuais (Sykes, 1994: 61).
} 
modo decisivo à consolidação do poder dessa Organização. No mesmo sentido, contribuiu ao fortalecimento da capacidade ostentada pelo PCC - cada vez mais favorecida pelo encarceramento massivo praticado junto ao abandono de qualquer premissa ressocializadora - em agregar mais e mais indivíduos quer como membros, quer como “simpatizantes” que colaboram na medida de sua proteção dentro do sistema, caracterizando-se aquilo que se tem comumente atribuído a esse exército: uma verdadeira “massa de manobra”, pronta a ser acionada a serviço do crime e da violência.

\section{A gestão de NAgASHI FuruKaWA (1999-2006) E A NOVA RACIONALIDADE PENITENCIÁRIA}

Sykes, ao analisar a importância desempenhada pelas rebeliões no sistema social da prisão, afirma que elas carregam um significado para além de um simples evento inesperado, por elas representarem a pública e completa negação da mais importante premissa na qual a prisão se constrói: a de que os guardas (os oficiais da prisão) mantêm um inquestionável poder sobre os presos (1994: 109).

Se essa afirmação de Sykes traduz o efeito exato provocado pela ocorrência desses eventos junto à opinião pública e ao imaginário popular no que se refere ao cotidiano da prisão, sobretudo num tempo em que se atribui a ela a exclusiva finalidade da contenção, a transmissão midiática, em tempo real, de uma rebelião envolvendo simultaneamente 27 unidades prisionais e 28 mil presos amotinados, em que eram clamadas palavras de ordem a um comando criminoso criado dentro das unidades, certamente pôde enterrar de modo definitivo a mais importante premissa sobre o cárcere de que nos fala Sykes.

A megarrebelião ocorrida entre 18 e 19 de fevereiro de 2001 nos presídios paulistas produziu um efeito ainda mais devastador para a administração penitenciária: atestou, de modo inconteste, a existência da organização criminosa PCC, concebida e fortalecida dentro dos cárceres paulistas. O evento pôde colocar em xeque, ainda, a posição oficial adotada durante quase uma década pelo governo em negar sua existência e, em última análise, acabou por comprometer a própria política penitenciária executada até o período. 
Na avaliação de Salla (2001), teria sido esse o sentido maior da mobilização do PCC, a demonstração de força para o governo, e não a denúncia das precárias condições de encarceramento que comumente as rebeliões invocam. Ainda segundo o autor, muito embora houvesse um conteúdo de reivindicações no evento, esse conteúdo apresentou um caráter essencialmente “corporativista”, ou seja, voltado aos interesses mais imediatos dos membros da facção - a desativação do “Piranhão” e a demissão do diretor Pedrosa - tendo sido inclusive uma nova transferência de alguns líderes do PCC ao Anexo o estopim da revolta.

O fato de que o caráter de denúncia da realidade carcerária não tenha sido o principal mote da megarrebelião promovida pelo PCC não impediu, contudo, que logo após o evento a imprensa conferisse ampla cobertura não apenas à existência da Organização, mas à situação de ineficiência e vulnerabilidade apresentada pelo sistema penitenciário. O destaque na mídia colocou novamente a questão carcerária em foco, o que praticamente não ocorria desde o Massacre de 1992, mas, como já apontado, não o fez através da promoção de um debate minimamente qualificado em torno do tema, ou seja, sem qualquer resgate à sua potência crítica, limitando-se a conferir a dimensão do fantástico e do inusitado, que geralmente episódios envolvendo as prisões acabam invocando junto ao imaginário popular.

De todo o modo, o episódio impôs ao governo a adoção de uma nova agenda para a questão penitenciária em regime de urgência, até pela exigência de caráter essencialmente simbólico que uma "resposta” ao PCC reclamava naquele momento, ou seja, a necessidade de enviar à população a mensagem que o Estado detinha o controle da situação. Desde então, as ações implementadas traduziriam cada vez mais o abandono às premissas sobre as quais a execução penal esteve um dia embasada, sendo responsáveis, em grande medida, por uma nova reorientação aos rumos da política penitenciária brasileira a partir desse momento.

PreCedentes: A QUESTÃo CRIMINAL NO PRIMEIRo MANDATO DE MARIO Covas (1995-1998) 
No que toca à área de segurança pública, o primeiro mandato de Mario Covas no governo paulista (1995-1998) foi marcado por iniciativas que representaram, em certa medida, a retomada de uma política de compromisso à defesa e garantia dos direitos humanos, em descontinuidade às práticas de violência institucional promovidas pelas últimas duas gestões no Estado. Durante o primeiro mandato, que correspondeu ao período em que Covas esteve efetivamente à frente da gestão, foram impressas ações que visaram o maior controle da atividade policial e, em última análise, a humanização das polícias.

Nesse contexto, destacaram-se algumas medidas de especial impacto à diminuição da violência policial e de democratização e controle dessa atividade. A primeira delas referiu-se à criação, já no ano de 1995, do Proar - Programa de Acompanhamento a Policiais envolvidos em Ocorrências de Alto Risco - visando o afastamento imediato e a reciclagem dos policiais militares envolvidos em mortes de civis. A criação do programa seria reforçada pela instalação de outro mecanismo de controle social, a Comissão sobre Letalidade das Ações envolvendo Policiais, composta por membros das polícias e representantes da sociedade civil. Mas foi a criação da Ouvidoria das Polícias do Estado de São Paulo, como um órgão dotado de relativa autonomia ${ }^{112}$, a medida que mais revelou a especial determinação de mudança no tratamento das questões relacionadas à segurança pública pelo governo Covas.

Enquanto estiveram em vigor e operantes, essas ações produziram os resultados esperados de modo a iniciar a reversão de um quadro de intensificação da violência policial a que se assistia desde o governo Quércia. Em 1996, pela primeira vez desde o ano de 1990, o número de civis mortos pela Polícia registrava queda. Em 2001, a Comissão sobre Letalidade apresentaria um relatório apontando a redução no número de civis mortos em confronto com PMs de 26,5\% em relação ao ano anterior. ${ }^{113}$

O segundo mandato de Covas, entretanto, seria marcado por seu precário estado de saúde que o levaria ao afastamento do governo no final do ano de 2000, assumindo então seu vice, Geraldo Alckmin. A orientação ideológica impressa à temática da segurança e justiça por Alckmin revelou-se bastante diversa daquela que vinha sendo adotada por seu antecessor, alinhando-se muito mais aos dois últimos governos antecedentes, tendo sido

\footnotetext{
${ }^{112}$ Dispôs a lei de criação da Ouvidoria da Polícia, que o Ouvidor seria nomeado a partir de lista tríplice enviada pelo Condepe - Conselho Estadual de Defesa da Pessoa Humana - e com mandato definido por lei.

${ }^{113}$ Programas foram desativados, Jornal Folha de S. Paulo, Caderno Cotidiano, 11 de fevereiro de 2004.
} 
responsável pela reversão da política de maior controle da atividade policial e de contenção dos abusos e da violência por ela cometidos.

A partir do ano de 2002, quando foi nomeado para a Secretaria de Segurança o promotor de justiça Saulo de Castro, autêntico representante da "linhha dura” e da truculência no trato às questões dessa área, a política de segurança no Estado de São Paulo reassumiria, de modo evidente, a feição conservadora e autoritária, expressa de modo mais eloqüente na retomada das práticas de extermínio contra os tradicionais segmentos "perigosos" da sociedade.

A gestão de Alckmin e Saulo de Castro será então responsável pela desarticulação do conjunto de iniciativas tomadas desde 1995, promovendo a desativação de programas como o Proar e a Comissão sobre Letalidade, bem como dando início ao processo de enfraquecimento da Ouvidoria através do cerceamento de dados, corte de recursos e lobby na nomeação de ouvidores ${ }^{114}$. Mas será na retomada, novamente explícita, da autorização para matar conferida à Polícia, que a gestão de Alckmin e Saulo de Castro revelará, de forma mais sintética e pragmática, sua orientação na área de segurança pública.

Entre os resultados dessa nova feição institucional à questão da segurança pública, estará, como não poderia deixar de ser, o aumento, desde então gradativo, dos índices de letalidade de civis por policiais em serviço. Já em 2002, registrar-se-ia um aumento de 32,8\% em relação aos números de 2001, representando o maior índice desde o início da gestão $\operatorname{Covas}^{115}$; em 2003, um novo e mais eloqüente aumento: 69\% em relação ao primeiro trimestre de $2002^{116}$.

Os números relativos a civis mortos em supostos confrontos com a PM permanecerão, a partir de então, em constante ascendência e serão, também uma vez mais, “louvados” e atribuídos pelas autoridades ao bom desempenho da atividade policial ${ }^{117}$,

\footnotetext{
114 Sobre o obstáculo imposto pela Secretaria ao fornecimento de informações à Ouvidoria, não obstante previsão legal, a matéria Governo de São Paulo quebra Ouvidoria da Polícia, Jornal Folha de S. Paulo, Caderno Cotidiano, 3 de outubro de 2002, a partir das declarações do então Ouvidor da Polícia, Firmino Fecchio. Com relação ao processo de nomeação do novo Ouvidor, matéria Polêmica marcou mandato anterior, Jornal Folha de S. Paulo, Caderno Cotidiano, 16 de junho de 2003.

115 Mortes de civis pela Polícia batem recorde, Jornal Folha de S. Paulo, Caderno Cotidiano, 31 de janeiro de 2003.

${ }^{116}$ Polícia mata 69\% a mais no primeiro trimestre, Jornal Folha de S. Paulo, Caderno Cotidiano, 29 de abril de 2003.

117 Todos os dados recentes acerca do aumento da letalidade e sua justificativa encontram-se no site da própria Secretaria, www.sspsp.gov.br acesso em 21/07/2006.
} 
traduzindo-se na equação polícia eficiente é aquela que mata. A truculência da ação policial constituirá assim a marca particular de um modelo de política de segurança calcada no arbítrio e na violência e definidora, sob muitos aspectos, da barbárie que se passará a assistir no cenário das questões relativas à segurança pública.

Muito embora, no que toca à política de segurança pública o período relativo ao primeiro mandato de Mário Covas tenha sido marcado por deslocamentos e inflexões, no que se refere à questão carcerária não se assistiria a importantes rupturas com relação ao modelo que vinha até o momento sendo adotado. Em certa medida, a ausência de mudanças mais estruturais acabou frustrando expectativas no sentido de que o reformismo humanizante de outrora alcançasse a prisão, através da adoção medidas que propusessem resgatar, por exemplo, o debate sobre o preso como sujeito de direitos, a exemplo do que ocorrera na gestão Montoro (1983-86).

É certo, contudo, que Covas desde o início de sua gestão tentou imprimir, ainda que simbolicamente, deslocamentos quanto ao modelo truculento e às práticas de extermínio que marcaram as gestões anteriores, o que pôde ser representado a partir dos nomes por ele escolhidos para comandarem a SAP. Num primeiro momento, Covas destinaria a Pasta de Administração Penitenciária a Belisário do Santos Junior, que a cumularia durante alguns meses com a Secretaria de Justiça e Defesa da Cidadania, até que, em meados de 1995, assumiria João Benedito de Azevedo Marques. Ambos os ex-Secretários eram pessoas ligadas a grupos de defesa dos direitos humanos; Belisário se notabilizaria como um destacado advogado defensor de presos políticos durante o regime; João Benedito, um procurador de justiça aposentado, também era conhecido por militar junto a movimentos de direitos humanos.

Contudo, a escolha de tais nomes não seria suficiente para que se imprimissem mudanças importantes quanto ao rumo da política penitenciária no período. Ainda que sem registrar a ocorrência de episódios de acentuada violência institucional como aqueles aos quais se assistiu nas administrações antecedentes, a política empreendida esteve marcada por uma certa continuidade com relação ao tratamento tradicionalmente dispensado à 
questão carcerária. Ou seja, ao lado de necessidades absolutamente prementes de expansão física do sistema em virtude da explosão da população carcerária que a década de 90 inaugurara, nenhuma outra diretriz seria impressa à política penitenciária no período, não só pela ausência de qualquer medida de caráter reintegrador, como pela continuada violação de direitos que o Estado perpetrava, quer no que tange à precariedade das condições de encarceramento, quer pela permanência das peculiares práticas de tortura no sistema.

Em verdade, a partir de meados dos anos 90, o sistema carcerário paulista viu-se imerso numa acentuada crise, expressa sobretudo por um número crescente de rebeliões e fugas que expunham, de modo cada vez mais evidente, as principais deficiências do sistema, naquele momento representadas pelas condições de precariedade das carceragens dos distritos policiais e da Casa de Detenção de São Paulo. Na base da deflagração de tal crise, a escalada da população encarcerada a partir do ano 1995, resultado das legislações criminais de urgência e da prevalência das políticas criminais conservadoras empreendidas a partir da década de 90, cujos principais efeitos começavam a ser sentidos no sistema penitenciário, "a ponta final da linha”.

Desse modo, no ano de 1996 registrar-se-iam 589 fugas de 3.957 presos de distritos e cadeias públicas do Estado ${ }^{118}$. Já o ano de 1997 seria marcado por uma intensificação de rebeliões e motins, registrando-se, até outubro, 14 rebeliões em presídios, sendo 5 delas na Casa de Detenção, número que representava, já àquele momento, mais que o dobro do ano anterior $^{119}$. Em dezembro de 1997, uma violenta rebelião na Casa de Detenção de Sorocaba, envolvendo 827 presos amotinados e 637 reféns entre funcionários e familiares visitantes por mais de 72 horas, deixaria ainda como saldo a morte de um detento e de um refém $^{120}$. No ano 1998, apenas nos distritos policiais seriam registradas 32 rebeliões ${ }^{121}$, bem como um importante aumento no percentual de fugas: 38,9\% no Estado e 48,5\% na Capital, com especial destaque para as cadeias públicas e os distritos policiais ${ }^{122}$.

\footnotetext{
${ }^{118}$ Dez fogem por dia de prisões de São Paulo, Jornal Folha de S. Paulo, 5 de agosto de 1997.

${ }^{119}$ Motins em presídios e DPs já superam 96. Jornal Folha de S. Paulo, 07 de outubro de 1997.

${ }^{120}$ Rebelados mantêm 637 reféns em Sorocaba. Jornal O Estado de S. Paulo, 30 de dezembro de 1997. Líderes de motim em Sorocaba são transferidos. Jornal O Estado de S. Paulo, 2 de janeiro de 1998.

${ }^{121}$ Natal acaba com fuga de mais de cem presos. Jornal O Estado de S. Paulo, 28 de dezembro de 1998.

${ }^{122}$ Fugas de presos aumentam 38,9\% no Estado, Jornal O Estado de S. Paulo, 21 de dezembro de 1998.
} 
Em meio à caótica situação de déficit de vagas e da precariedade dos estabelecimentos, o governo estadual acenava com as propostas de desativação das carceragens dos distritos policiais e da Casa de Detenção de São Paulo, essa última, aliás, já prevista como uma medida imperiosa desde o governo Montoro. Para tanto, demandavase um investimento massivo na construção de presídios, como o que de fato se passou a assistir, sobretudo a partir de $1998^{123}$, com a liberação de recursos federais e estaduais para a instalação de novas unidades no interior do Estado, numa política de interiorização ${ }^{124}$ do cumprimento da pena, ou seja, de transferência dos presos da Capital para penitenciárias no interior do Estado, política essa que seria intensificada pela administração subseqüente.

Para além, contudo, das anunciadas medidas de dotação de vagas, persistiam, do ponto de vista administrativo, as mesmas deficiências estruturais com as quais o sistema convivera desde há muito e para as quais a criação da SAP não houvera contribuído no sentido de sua superação, contrariando as expectativas nela depositadas à época.

O sistema COESPE havia sido concebido em 1979 para atender uma necessidade premente à época que vinha a ser a de conferir à questão carcerária uma independência em relação à política geral de segurança pública a qual sempre esteve atrelada. Àquela época, havia cerca de 15 unidades prisionais subordinadas à COESPE. Com o passar dos anos, foi justamente o próprio inchaço do sistema e o incremento cada vez maior de presos e de estabelecimentos carcerários que impôs a necessidade de criação de uma Secretaria autônoma que pudesse melhor distribuir a competência e racionalizar a administração penitenciária, uma vez que a COESPE, por se tratar apenas de uma coordenadoria, apresentava uma estrutura deficiente para dar conta das mais de 50 unidades prisionais já então existentes.

Entretanto, desde o momento em que a SAP fora criada, em 1993, ainda sob o governo Fleury e mesmo durante a gestão do Secretário João Benedito de Azevedo Marques no governo Covas (1995-1999), sua existência manteve-se adstrita como a de um órgão de mera articulação política, cumprindo o Secretário de Administração Penitenciária a função do tipo de um "chefe de estado" e não de um gestor propriamente dito. Isso significou a manutenção de uma estrutura burocrática e administrativa na qual o poder se

\footnotetext{
${ }^{123}$ Presos começam a ser transferidos hoje. Jornal Folha de S. Paulo, 19 de agosto de 1998.

${ }^{124}$ Segundo depoimento de Nagashi Furukawa, na gestão de João Benedito de Azevedo Marques (19951999) teriam sido construídas 18 novas penitenciárias no interior do Estado, havendo mais 3 em fase de construção no momento em que a Secretaria fora transmitia a Nagashi (entrevista realizada em 31/08/2006).
} 
concentrava na figura única do coordenador ${ }^{125}$ da COESPE, ao qual verdadeiramente todos os diretores, técnicos e agentes se remetiam, constituindo-se em torno dele uma instância decisória de fato.

Esse anacrônico arranjo institucional propiciou a permanência de uma série de vícios e deficiências estruturais no interior do funcionamento do sistema, dos quais a corrupção e a violência permaneciam como as marcas mais evidentes, constituindo-se ainda como autênticos entraves para que, enfim, o conjunto, de certo modo aleatório, de práticas e ações pudessem ser ordenadas e definidoras de uma política penitenciária de caráter mais autônomo e de maior permanência.

\section{A EXCEÇÃo GENERALIZADA DO RDD E A “RESSOCIALIZAÇÃo” DOS CRS: DOIS TEMPOS DE UMA HISTÓRIA}

Nagashi Furukawa era então um juiz de execuções criminais e corregedor dos presídios em uma comarca de médio porte no interior de São Paulo, Bragança Paulista, quando, no final do ano de 1995, solicitaria uma audiência ao Governador Mario Covas. A razão para o encontro era que Nagashi percebera que o custo/preso na administração da única cadeia da cidade mostrava-se bastante elevado e desproporcional aos "benefícios" correspondentes, o que o teria levado a idealizar uma solução mais eficiente.

A proposta do então juiz a Mario Covas foi que o governo do Estado firmasse um convênio com uma associação que contava com certa tradição na atuação em presídios, a

\footnotetext{
${ }^{125}$ Lourival Gomes foi o mais destacado coordenador da COESPE até 2000; considerado o "homem forte” da administração penitenciária, foi demitido no início da gestão de Nagashi Furukawa depois de uma série de acusações sobre irregularidades durante os anos em que comandou a Coordenadoria. Lourival se notabilizaria como uma figura bastante polêmica no cenário da administração prisional, acusado ainda de ser o principal responsável pela promoção de uma política marcada tanto pela violência (tortura, maus tatos) intramuros quanto por esquemas de corrupção expressos por financiamentos de fugas e transferências para integrantes do crime organizado. Numa demonstração da fragilidade das instituições democráticas e dos mecanismos de controle da administração pública pela sociedade civil, Lourival Gomes retornaria à Pasta da Administração Penitenciária, em junho de 2006, como Secretário Adjunto, logo após o afastamento de Nagashi Furukawa no mesmo mês. (Entidades criticam secretário-adjunto do sistema prisional. Jornal Folha de S. Paulo, Caderno Cotidiano, 13 de junho de 2006).
} 
APAC $^{126}$ - Associação de Proteção e Assistência aos Condenados -, para que essa passasse então a gerir a cadeia pública mediante o repasse da mesma quantia que era paga à empresa que fornecia apenas a alimentação aos presos.

Sob a supervisão de juiz corregedor Nagashi Furukawa, a experiência dessa cogestão iniciada em $1^{\text {o }}$ de janeiro de 1996 na cadeia pública de Bragança Paulista renderia propagados frutos. A Associação conseguiria reformar o estabelecimento, promovendo uma administração diferenciada, a partir da qual os presos trabalhavam, estudavam e possuíam uma certa margem de liberdade intramuros, obtendo-se, como resultado mais evidente, a diminuição dos casos de fugas e motins ${ }^{127}$.

Nos anos que se seguiram, a divulgação da experiência de participação comunitária no cumprimento da pena (usando os termos de seu idealizador) realizada em Bragança, notabilizaria Nagashi como o principal responsável pela concepção e execução de uma “exitosa” proposta de reforma e ressocialização ao cárcere, num momento em que as rebeliões, fugas e o déficit de vagas ostentavam a falência do sistema penitenciário paulista.

Mesmo sem um efetivo programa para a questão carcerária, Mario Covas apoiaria a experiência de Bragança e seu idealizador, vendo nesse modelo uma alternativa, ainda que não exclusiva, para o enfrentamento da crise em que se encontrava o sistema penitenciário àquele momento. Desse modo, após se aposentar da carreira de magistrado, Nagashi assessorou a Secretaria de Segurança Pública durante alguns meses na tentativa de implantar o modelo de gestão comunitária em cadeias, e, após três meses como diretor do DEPEN/MJ na gestão de José Carlos Dias no Ministério da Justiça, ainda sob o governo Fernando Henrique, assumiria, em dezembro de 1999, a Secretaria de Administração Penitenciária de São Paulo.

Naquele momento, as grandes metas que se colocavam diziam respeito à dotação física do sistema e consistiam na desativação das carceragens dos distritos policiais e da Casa de Detenção de São Paulo, com a transferência derradeira da custódia dos presos da

\footnotetext{
${ }^{126}$ As APACs foram criadas na década de 70, no Estado de São Paulo, constituindo-se como organizações ligadas a segmentos da Igreja Católica, destacando-se a APAC de São José dos Campos. Sua atuação nos cárceres sempre esteve ligada ao trabalho de orientação religiosa e assistência material de caráter pontual nas prisões, sendo a experiência de Bragança a primeira em que esse tipo de organização assumia um papel de co-gestão na administração de um estabelecimento prisional.

${ }^{127}$ Entrevista realizada com o ex-Secretário em 31/08/2006 e matéria Covas inicia novo modelo de gestão para cadeias, Jornal Folha de S. Paulo, 9 de janeiro de 1996.
} 
Secretaria de Segurança Pública (que àquela época respondia por $40 \%$ da população encarcerada) para a Secretaria de Administração Penitenciária.

É certo, contudo, que a escolha do nome de Nagashi para a SAP não pôde deixar de significar a tentativa de se efetivar, ainda que sem a dimensão emancipatória de outros tempos, um conteúdo de maior humanização e reintegração no tratamento da questão carcerária. A tímida e também controversa proposta de Nagashi de gestão comunitária em presídios de pequeno porte como principal diretriz política para a Secretaria consistia também, naquele momento, ao menos no projeto mais inovador para a questão penitenciária que se assistia desde a experiência da humanização durante a redemocratização.

Segundo Nagashi, tal “diretriz”, representada na experiência da APAC em Bragança, teria sido a única condição colocada por ele para assumir o cargo oferecido pelo Governador Covas:

Se for para continuar construindo só penitenciárias grandes que serão administradas pelo modelo tradicional, o senhor pode procurar outro. Se o senhor me autorizar a construir um modelo a exemplo do que foi feito em Bragança, aí eu virei.

Evidentemente que nem o Governador nem o recém-empossado Secretário acreditavam que poderiam, naquele momento, adotar o modelo de pequenas penitenciárias co-geridas pela “comunidade” como principal solução para um sistema no qual remanesciam mensalmente centenas de presos e para o qual só uma frenética expansão física poderia livrar de um iminente colapso. No entanto, é também certo que a escolha por Nagashi representaria uma vez mais a aposta no resgate, embora menos contundente, da função ressocializadora do cárcere através de um programa em tese norteado por essa finalidade.

Se os anos que se seguiram testemunharam o fracasso dessa aposta, suas causas devem ser buscadas muito mais a partir do contexto de profundas transformações das práticas punitivas, tanto a nível internacional, como sobretudo, nacional, do que pela gama de intenções e orientações que os sujeitos especialmente implicados nesse contexto teriam sido portadores.

De todo o modo, abandonando ou não as premissas ressocializadoras que guiavam suas propostas, a gestão Nagashi foi, por diversos aspectos, fundamental e emblemática na 
definição de um quadro de referências a partir do qual a política penitenciária contemporânea pautar-se-ia, desde então, para além do próprio Estado de São Paulo.

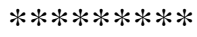

Quando indagado sobre se a megarrebelião de 18 de fevereiro de 2001 e a conseqüente demonstração de existência e força do PCC teriam imposto uma reorientação nos rumos da política adotada a partir de então, o ex-Secretário foi taxativo:

Não foi a megarrebelião de fevereiro de 2001 que mudou essa orientação, o que mudou mesmo foi que em março de 2001 morreu Mario Covas. E quem verdadeiramente tinha comprado essa idéia de participação comunitária na administração penitenciária, de priorizar o aspecto da ressocialização, de construir unidades menores era o Mario Covas. Compromisso que o governo de Geraldo Alckmin não tinha. (...) Ele até deu continuidade a essa política, mas num ritmo que eu diria bem menor. ${ }^{128}$

O que Nagashi deixava claro por essa declaração é que, a partir de 2001, todo um projeto que priorizava a adoção de um determinado modelo de unidade prisional como principal projeto de reintegração social à população encarcerada, que se institucionalizaria pelo nome de Centro de Ressocialização - CR, fora colocado num segundo e menos destacado plano. Segundo ele, o fato do governador Alckmin não aderir ao aspecto de ressocialização na administração penitenciária como seu antecessor, teria sido a principal causa para que tal política não fosse levada adiante e tivesse a mesma centralidade que o então Secretário desejava-lhe imprimir. Sua percepção acerca do que conferiria ou não uma orientação mais humanizadora às políticas para o cárcere naquele momento se resumiria, assim, no fato do projeto sobre os CRs ser ou não efetivado.

O fato aparentemente mais notório para a reversão dessa orientação, a criação do regime disciplinar diferenciado - RDD - e depois sua intensificação e generalização por diversos Estados da federação, como um desdobramento da megarrebelião de 2001, não é, contudo, reconhecido por seu principal autor, o ex-Secretário Nagashi, como um elemento que colidisse com o ideal ressocializador. Para além do fato de que a negativa de tal

\footnotetext{
${ }^{128}$ Entrevista realizada em 31/08/2006.
} 
reconhecimento possa implicar numa estratégia retórica ou mesmo numa explícita contradição, é certo que tanto essa ordem de discurso - centrada na ressocialização quanto a heterogeneidade das ações empreendidas - a coexistência dos CRs e do RDD constituíram a marca particular de uma administração que "endureceu” suas práticas, sem ter "endurecido" seu discurso. Ou seja, sob um discurso de preservação dos direitos humanos dos presos e de humanização da prisão, estendeu a exceção a amplos domínios, exaltando-a ainda a um estatuto de legalidade.

Mas essa aparente contradição não pode ser inscrita simplesmente a partir de uma defasagem entre discurso e prática, reduzida a mera retórica demagógica de um homem público. Antes de mais nada, referidas ações e práticas discursivas, à primeira vista em flagrante oposição, compuseram um campo de intervenção no qual ambas se articularam, emprestando-se mútua funcionalidade e garantindo à gestão Nagashi a medida de apoio necessária à sustentabilidade de suas principais iniciativas, cuja culminância teria se dado com a aprovação do projeto de lei de sua autoria, que alteraria a LEP de 1984.

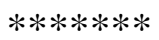

Logo no primeiro ano de sua gestão, ainda sob o governo de Mario Covas, Nagashi daria consecução a mudanças importantes na estrutura administrativa e organizacional da SAP e no processo de institucionalização do modelo de gestão comunitária dos presídios.

No que toca às mudanças organizacionais, o ex-Secretário iniciara enfim a reforma administrativa que deveria ter sido promovida quando da criação da SAP em 1993, ou seja, a descentralização da COESPE e a conseqüente transferência das atividades de gestão e, enfim, do maior núcleo de poder, das mãos do Coordenador para as do Secretário de Estado. Já em 2000, Nagashi demitiria o Coordenador Lourival Gomes e extinguiria seu cargo, dando margem à reformulação que seria oficializada pela Lei Complementar 897 de 11 de maio de 2001, através da qual a COESPE seria formalmente extinta, criando-se em seu lugar 6 coordenadorias, 5 por região do Estado e 1 de saúde.

A reformulação da COESPE redundou numa medida fundamental à uniformização das ações empreendidas no campo das práticas penitenciárias e, nesse sentido, para enfim possibilitar seu ordenamento enquanto uma política de Estado. No mesmo sentido, tal 
mudança trouxe a figura do Secretário de Administração Penitenciária a uma posição estratégica e central no funcionamento da Secretaria, tendo sido decisiva ainda para a consolidação do poder de Nagashi na qualidade de administrador, ou seja, no âmbito interno da SAP, o que também se revelou fundamental para a garantia da sustentabilidade ao conjunto das ações empreendidas.

Também ainda durante o mandato de Covas seriam elaborados os instrumentos legais necessários para erigir o modelo de co-gestão comunitária em presídios numa política institucional da SAP. Através do Decreto 45.403 de 16 de novembro de 2000, o Estado autorizava a celebração de convênios entre a Administração Penitenciária e entidades privadas sem fins lucrativos para o compartilhamento da gestão dos Centros de Ressocialização - CRs. Com a finalidade de prestação de serviços de proteção $e$ assistência ao preso visando sua reabilitação, a privatização entrava no sistema pela porta da frente, através da prestação de todos os serviços nessas unidades, com exceção da segurança e da disciplina.

Ao lado de tais iniciativas, entretanto, a construção de presídios de porte médio a grande no interior do Estado pelo modelo "tradicional” mantinha seu ritmo intenso, dandose continuidade assim às metas de desativação das carceragens e da Casa de Detenção da Capital a partir da transferência massiva de presos para as cidades mais longínquas à Capital. Referido modelo de dispersão de presos pelo Estado para cumprimento de pena consistiu em verdade na manifestação de numa renovada política de segregação, que fez reviver antigas práticas de expulsão e afastamento de indivíduos do corpo social como o degredo, o desterro, a deportação às colônias penais e mesmo a reclusão em presídios-ilha, cujo modelo é bastante pungente na história das prisões brasileiras ${ }^{129}$. Tal política, além de evidenciar as novas finalidades a partir das quais o encarceramento tem se orientado - a já tematizada sobreposição dos fins incapacitadores sobre os ressocializadores da prisão (Garland, 2005) - também denota uma opção no tratamento da questão carcerária que prima por estratégias de ocultamento da realidade intramuros, através das dificuldades interpostas ao acesso, tanto de familiares quanto das instituições e organismos que

\footnotetext{
${ }^{129}$ Para citar apenas alguns exemplos: o arquipélago de Fernando de Noronha/PE abrigou, segundo registros junto às ruínas existentes ainda hoje no local, presídios dessa espécie desde o século XVIII, inclusive para o recolhimento de mulheres. Até o período da ditadura Vargas, o local ainda receberia presos políticos. Ilha Grande/RJ, mesmo antes de abrigar o presídio de segurança máxima Cândido Mendes, também segundo registros em suas ruínas, teria servido de sede para antigos locais de confinamento, espécies de leprosários, cujos internos não eram apenas doentes. O presídio de Ilha Anchieta/SP, também destinado a receber presos perigosos, foi desativado na década de 1950, como já apontado.
} 
poderiam exercer alguma espécie de controle ao exercício da atividade punitiva no cárcere (Martins, 2001).

Ao largo disso, o PCC continuaria a crescer dentro dos presídios do Estado e a demonstrar sua força também para além deles. Antes ainda da megarrebelião de 2001, em dezembro de 2000, um violento motim no Anexo de Taubaté seria promovido pelos fundadores e líderes do PCC, tendo sido apresentadas as mesmas reivindicações que pouco tempo depois se renovariam: a desativação do "Piranhão" e a transferência dos presos ao sistema (CPI Sistema Prisional, 2001). Na ocasião, teriam sido impressas as mesmas marcas de crueldade às ações da Organização, especialmente na execução de presos rivais, a exemplo do que ocorrera em 1993 quando da fundação do PCC.

Em 18 de fevereiro de 2001, contudo, o PCC resolveria deflagrar sua existência para a toda a população e, de modo inédito, demonstrar seu poder no amotinamento simultâneo de 27 unidades prisionais e 28 mil presos. A resposta da Secretaria viria, uma vez mais, a partir de dispositivos disciplinares centrados, sobretudo, na exceção.

Assim, logo após a megarrebelião, o Secretário Nagashi, os coordenadores e um assessor especial que ocupava o cargo de Ouvidor da SAP, Pedro Armando Egydio de Carvalho, permaneceriam reunidos durante dias para a elaboração da resolução que instituiria o regime disciplinar diferenciado - RDD, como principal medida anunciada para o combate das organizações criminosas nos presídios paulistas. Segundo Pedro Egydio, naquele momento eram intensas as pressões que se exerciam no sentido de "endurecer" ao máximo o tratamento aos presos envolvidos em facções e com problemas de indisciplina. Ainda segundo o Ouvidor, ele próprio - um procurador do estado aposentado notório defensor dos direitos dos presos - e o Secretário Nagashi representavam, naquele grupo, os que mais resistiam à idéia de um instrumento que restringisse por demais as garantias desses reclusos, mas que teriam sido vencidos pela posição da maioria e pela força das circunstâncias $^{130}$.

À primeira vista, contudo, a Resolução $n^{0} 26$ de 04/05/2001 pôde parecer um instrumento menos arbitrário do que os que lhe antecederam (as resoluções de 1987 e de 1993 sobre o "Piranhão”), tendo sido justamente essa aparência de maior racionalidade que possibilitou a generalização indiscriminada do RDD para muito além de um único

\footnotetext{
${ }^{130}$ Entrevista realizada em 09/08/2006.
} 
estabelecimento prisional $^{131}$, não obstante ser ele portador das mesmas ilegalidades do regime anterior e instituir, do mesmo modo, as regras de exceção.

Havia ainda uma certa dose de sofisticação nas previsões e nos termos empregados pela Resolução $\mathrm{n}^{\circ} 26$, representada tanto pelo esforço retórico em estabelecer uma sorte de princípios e finalidades à instituição do regime como na insistente tentativa de conferir-lhe um caráter constitucional e legal de preservação de direitos, quando promovia, em sentido oposto, sua derrogação. Esse é o sentido que se depreende dos parágrafos introdutórios da resolução:

Os objetivos de reintegração do preso ao sistema comum devem ser alcançados pelo equilíbrio entre a disciplina severa e as oportunidades de aperfeiçoamento da conduta carcerária. O regime disciplinar diferenciado é peculiar, mas, apesar de seu rigor, não pode ser discriminatório, permanente ou afrontador das disposições das Constituições da República e do Estado e da Lei de Execução Penal.

Com essa introdução, que lograva a impossível conciliação entre o Estado de direito e a supremacia disciplinar, passava a Resolução a prescrever as hipóteses de ingresso no RDD e os procedimentos relativos à autorização e ao tempo de permanência no regime. É com relação a esses novos dispositivos que Nagashi vislumbraria o "grande avanço” da Resolução em relação aos instrumentos anteriores que disciplinavam o regime de readaptação penitenciária de Taubaté. Segundo ele, a nova resolução diminuíra em muito a margem de subjetividade posta à definição das hipóteses de inserção de um preso no regime, bem como extraíra o conceito de periculosidade como um requisito autorizador dessa inserção; o outro "avanço", ainda segundo ele, referia-se ao fato da previsão dos prazos de internação no RDD não serem mais indeterminados como eram no regime do "Piranhão"132.

A verdade, contudo, é que a resolução que criou o RDD recorreu a uma maior dose de “subjetividade”, ou ainda, de absoluta imprecisão quanto aos requisitos autorizadores da

\footnotetext{
${ }^{131}$ A resolução 26 fez menção a 4 unidades prisionais nas quais o RDD vigoraria, entre elas o próprio Anexo de Taubaté. Com o tempo, o número de unidades foi sendo inflacionado, assim como as subespécies do regime, como é o caso do RDE (regime disciplinar especial), na verdade uma variação do RDD utilizado para manter o preso por mais tempo em isolamento, já que a resolução 26/01 previa um prazo determinado. Referido regime já foi alvo de denúncia por parte do Ministério Público Federal, que propugnou pela extinção do regime (Procuradores pedem a extinção de regime especial em SP, Revista Consultor Jurídico, 22 de fevereiro de 2006). Com a aprovação da lei federal 10.792/03 que autorizaria uma prorrogação praticamente indeterminada do RDD, o RDE cairia em desuso.

${ }^{132}$ Entrevista realizada em 31/08/2006.
} 
inclusão do preso no regime. A partir de uma surpreendente capacidade de síntese, a Resolução 26/2001 previu “apenas” duas hipóteses de aplicação do RDD: aos líderes e integrantes de faç̧ões criminosas e aos presos cujo comportamento exija tratamento específico (art. $1^{\circ}$ Resolução 26/01).

Desse modo, ao invés de se “delongar” na descrição de condutas e crimes que ensejariam a transferência do preso ao regime mais severo como fez a resolução 78/93, a nova resolução do RDD resumiu a apenas um ato: a participação em facções criminosas. No entanto, a exemplo da resolução anterior, garantiu o exercício do arbítrio e da exceção justamente através daquilo que o ex-Secretário denominou “margem de subjetividade”, só que dessa vez, ao contrário de sua avaliação, essa margem foi ainda mais estendida. Ou seja, no lugar da prática de atos de violência e subversão reveladores de periculosidade

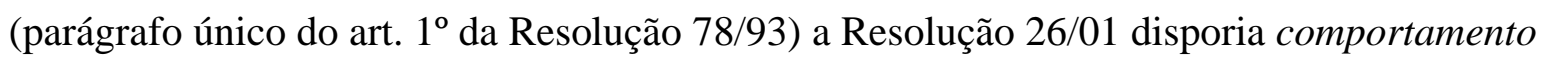
que exija tratamento específico, como requisito para inclusão do preso no regime disciplinar diferenciado.

Desse modo, tal disposição acabou sendo portadora de uma esfera ainda maior de indeterminação, conferindo ao diretor do presídio e ao administrador em geral ${ }^{133}$ a total discricionariedade para inclusão no RDD dos presos que bem desejasse, uma vez que não exigiria sequer o cometimento de algum ato específico do preso para que sua transferência ocorresse. No mesmo sentido, a ausência de uma clara significação quanto aos termos que qualificariam as hipóteses de aplicação do RDD - como é o caso de comportamento que exige tratamento específico - reforçaram seu emprego indiscriminado e, por conseqüência, fadado ao arbítrio.

Por outro lado, os dispositivos que viabilizavam a prorrogação indeterminada do prazo de internação do regime do Anexo de Taubaté seriam substituídos, na Resolução 26, por um prazo máximo improrrogável de 180 dias na primeira inclusão e de 360 dias nos casos de "reincidência”. No mais, as disposições sobre isolamento por 23 horas, banho de sol de 1 hora e toda a severidade que um castigo na prisão geralmente carrega, seriam mantidos em estritos termos e, mais uma vez, em colidência direta com a Lei de Execuções Penais e a Constituição Federal. Mais uma vez também o Judiciário, mesmo chamado a se pronunciar sobre a inconstitucionalidade e a ilegalidade do RDD em diversas

\footnotetext{
${ }^{133}$ A exemplo da resolução anterior, a resolução 26 previu apenas a posterior comunicação ao juiz das execuções criminais, mais uma vez ferindo o princípio da jurisdicionalidade na execução penal.
} 
oportunidades por uma Defensoria Pública que, nesse momento se insurgia contra a Resolução 26, não proferiria uma só decisão nesse sentido, apesar de todos os artigos da Resolução ferirem diretamente as regras da LEP e da Constituição Federal.

É certo, portanto, que a criação do RDD e sua generalização traduziram, antes de mais nada, uma opção no tratamento da questão das organizações criminosas nas prisões, na qual uma vez mais não foram priorizadas medidas que efetivamente combatessem sua existência, mas sim, dispositivos que intensificaram a exceção e a violência do Estado, reforçando a persistente confusão entre segurança e disciplina que as políticas para o cárcere têm sido portadoras. Tais dispositivos colocam em primeiro plano tão-somente a dimensão do castigo, não sendo garantido, contudo, um conjunto de ações por parte do Estado que efetivamente mine as condições de atuação do crime organizado dentro das cadeias: a rede de comunicações interna e externa e a corrupção dos agentes encarregados pela custódia das lideranças e dos membros das organizações. É por isso que decorridos cinco anos de instalação do RDD, não se assistiu ao declínio ou ao fim do PCC como as autoridades ansiosamente clamavam até maio de 2006; ao contrário, sua expansão para além dos muros das prisões demonstra insistentemente o quanto a violência institucional mantém-se como um fator de especial relevância à compreensão da gênese e do fortalecimento dessas organizações.

Embora o RDD possa ter representado, por alguns aspectos, uma certa continuidade no modo de tratar da questão disciplinar nas prisões, não deixou, ao mesmo tempo, de significar uma "mudança de patamar" em relação ao obscuro sistema de execução de castigos do Anexo de Taubaté. No processo de institucionalização e expansão do RDD, transformou-se aquilo que era marginal, ocultado e improvisado, no principal instrumento de uma política de contenção concebida e gerida com a finalidade de promover a defesa da sociedade. Essa política se realizaria não mais em precários locais improvisados para esse fim - os fundos e porões de estabelecimentos penitenciários a exemplo do Anexo de Taubaté - mas mediante o aporte de volumosos recursos ${ }^{134}$ à construção e ao

\footnotetext{
134 Segundo o ex-Secretário Nagashi informou, o Estado despende em torno de $\mathrm{R} \$ 60.000,00$ por cela individual numa unidade de RDD; já o custo mensal de manutenção de um preso no RDD seria da ordem de R\$3.000,00, mais do triplo do que num presídio comum. Nas Supermax norte-americanas (vide definição na próxima nota), segundo Rhodes (2004) citando os dados do Nacional Institute of Corrections de 1997, o custo de manutenção mensal de um preso seria de U\$ 4.500,00.
} 
aparelhamento de unidades que, de modo mais "asséptico" e fortemente inspiradas nas supermax norte-americanas ${ }^{135}$, executariam essa agora “racional” política.

Mas foi também em razão desse processo de aparente “racionalização" do tratamento da questão disciplinar, que o RDD pôde ser fortemente polemizado e contestado por juristas, intelectuais, organizações de defesa dos direitos dos presos e pelo órgão encarregado da Defensoria Pública no Estado ${ }^{136}$. Desse modo, também à diferença do que ocorrera com o regime de adaptação penitenciária de Taubaté, o RDD praticado em alguns presídios do Estado foi questionado, tanto em sua existência quanto no modo de sua execução, estando assim suas práticas mais expostas a, pelo menos, alguma esfera de discussão.

Do mesmo modo que ensejou críticas, o aparente êxito do RDD também atraiu a atenção de governantes e políticos que veriam nessa experiência "civilizadora” uma solução para a questão carcerária. Assim, não demoraria muito para que outros Estados da federação adotassem seus exemplares de RDD (Paraná, Mato Grosso do Sul, Rio de Janeiro), bem como que se despertasse o interesse por sua "legalização" e definitiva institucionalização em âmbito federal, por parte dos Poderes Executivo e Legislativo.

Os desdobramentos desse interesse sobre o modelo do RDD viriam dois anos e meio mais tarde com a modificação da LEP, como será discutido a seguir, e a inserção oficial, com algumas modificações, de tal regime no ordenamento jurídico nacional, pese, uma vez mais a exemplo das legislações criminais de exceção dos anos 90, sua evidente inconstitucionalidade.

\footnotetext{
${ }^{135}$ Supermax é um tipo de presídio de segurança máxima concebido nos EUA e propagado como um modelo de exemplaridade no "tratamento" de criminosos, sendo um paradigma contemporâneo de prisão póswelfarismo penal. Como característica essencial está justamente o regime aplicado de isolamento por 23 horas e padrões de extrema segregação, representados pelo mínimo contato permitido ao preso com quaisquer outros indivíduos e com o mundo exterior. Em 1997, os EUA contavam com mais de 60 Supermax instaladas em seu território, quase todas construídas durante os últimos vinte anos (Rhodes, 2004).

${ }^{136}$ O IBCCRIM - Instituto Brasileiro de Ciências Criminais, entidade composta especialmente por juristas, foi o mais insistente opositor do RDD, tendo se posicionado em alguns editoriais de sua publicação mensal (O RDD e a ideologia da disciplina, Boletim $\mathrm{n}^{\circ}$ 123, fevereiro de 2003; O RDD é caso de polícia, Boletim $\mathrm{n}^{\circ}$ 126, maio de 2003) e por diversos artigos de seus associados. Organizações como a Pastoral Carcerária também se opuseram ao regime, inclusive por meio de abaixo-assinados. Tão logo a experiência do RDD passou a ser reproduzida em outros Estados, demais associações e institutos, sobretudo de advogados criminais, também contestaram a criação do regime.
} 
Ao lado, portanto, da instalação das zonas de exceção que constituíram os locais de aplicação do regime disciplinar diferenciado, a administração penitenciária do período, no que toca ao gerenciamento da massa carcerária, teve diante de si um desafio de grandes proporções: administrar um sistema que gerava um saldo mensal de 913 presos remanescentes. Equivale dizer que, a cada mês, a diferença computada entre os indivíduos que entravam e os que saíam do sistema era da ordem de cerca de mil indivíduos, o que exigiria do governo estadual a construção de dois novos presídios por mês. Durante a gestão Nagashi, contudo, chegou-se perto dessa façanha: a cada mês, uma nova prisão foi construída, totalizando-se 82 novas unidades prisionais nos 78 meses em que esteve à frente da SAP, para abrigar o aumento referente a 71.000 presos. ${ }^{137}$

A eloqüência de tais números teria imposto, conseqüentemente, um pesado investimento público com vistas ao aparelhamento e à manutenção de uma gigantesca e onerosa estrutura de aprisionamento, que tem se mantido em franco crescimento desde meados dos anos 90. Esses números, relativos tanto ao incremento de encarcerados quanto aos recursos aportados, também chamam a atenção e provocam indignação das elites e da população em geral, que não se dispõem a enxergar, contudo, o que redunda óbvio: que a política de maior punitividade a qual apóiam e são incentivadoras ${ }^{138}$ e cujo produto imediato é um contingente massivo de indivíduos encarcerados, é altamente dispendiosa para os cofres públicos e absolutamente desastrosa, a curto prazo, para um país periférico como o Brasil.

Nesse contexto, as propostas acabam por girar sempre em torno da permanente e falaciosa solução neoliberal da privatização, nesse caso, a privatização dos presídios, sob os auspícios de uma clamada redução de custos por parte do Estado. Como a experiência das privatizações de serviços públicos em geral tem desmistificado essa crença e, mais especialmente, a experiência de presídios privatizados em países como os EUA têm

\footnotetext{
${ }^{137}$ Todos esses dados relativos à gestão de Nagashi Furukawa foram fornecidos pelo próprio, em entrevista realizada em 31/08/2006.

${ }^{138}$ Recente pesquisa realizada pelo Ibope/OESP revela o conservadorismo nas representações da população sobre a questão do crime e da punição, numa demonstração de continuidade ao que Adorno (1996) denominou autoritarismo social. Os dados apontam que quase $40 \%$ dos paulistas defendem punições rígidas a todos tipos de crimes; a maioria esmagadora é favorável à redução da maioridade penal, $85 \%$, e à proposta de obrigar presos a trabalharem, $97 \%$. $37 \%$ são contra o sistema de progressão das punições e contra a política que evita misturar quem cometeu pequenos delitos com condenados perigosos. (85\% apóiam redução da maioridade, Jornal O Estado de S. Paulo, 2 de agosto de 2006).
} 
revelado um gasto ainda superior do Estado na manutenção desse modelo (Christie, 1999), tal aposta tem se concretizado muito lentamente em países como o Brasil.

No entanto, como não é a discussão sobre princípios e valores que referencia o debate, uma vez que o monopólio estatal da segurança soa anacrônico e ultrapassado numa sociedade já tomada pelo paradigma do controle e seus corolários (Garland, 2005), a lógica utilitarista continua a exigir adequações para o problema do cárcere.

É nesse contexto que os Centros de Ressocialização - CRs -, criados e defendidos pelo ex-Secretário Nagashi, podem ser inseridos e problematizados. Isso porque, embora propagados desde o início de sua gestão como a grande aposta humanizadora e ressocializadora para o cárcere, a lógica e as finalidades que realmente o inspiraram - e que nada se identificam a esses atributos - jamais teriam sido escondidas ou negadas por seus próprios criadores.

Durante a gestão de Nagashi, a SAP promoveria uma redução de 18 mil funcionários em seu quadro. Essa redução, que representou também um aumento no número da proporção preso/funcionário, saltando de 2,16 presos para 1 funcionário em 1999 para 3,86 presos para 1 funcionário em 2002, seria também altamente publicizada e louvada pela Secretaria, segundo o teor dos balanços anuais realizados através das “Mensagens do Secretário” divulgadas no site da SAP. A razão para tal “comemoração” consistia no fato de que, com tal redução, o custo mensal de manutenção de um preso no sistema também diminuíra: passava de R\$1.000,00 em 1999 para R\$ 767,00 em 2003, ou seja, uma redução de $23 \%{ }^{139}$.

Referida “economia” teria sido conseguida à custa da tão clamada co-gestão privada dos 23 CRs que foram implantados no Estado ao longo do período, segundo os mesmos postulados da experiência da administração da APAC na Cadeia Pública de Bragança, que atraíra, em 1996, as atenções de Mario Covas e destacara Nagashi nessa área.

A grande estratégia do ex-Secretário Nagashi foi, em verdade, colar a esse modelo de “eficiência” representado na co-gestão privada em presídios, a marca da ressocialização, através da atraente expressão participação comunitária no cumprimento da pena. Mas, afinal, de que se trata a ressocialização a qual Nagashi se remete insistentemente?

139 “Mensagens do Secretário” dos anos de 2002 e 2003. www.admpenitenciária.sp.gov.br acesso em abril de 2006. 
Certamente não se refere ao projeto que teve, tanto no modelo institucional do welfarismo penal no primeiro mundo como na aposta do sujeito de direitos no cárcere já nos 80 no Brasil, importantes retratos. Não se trata disso; a ressocialização dos CRs remete a mais um exemplo da indistinção entre o público e o privado que a contemporaneidade tem produzido, à confusão entre cidadania e filantropia, entre direitos e responsabilidade social, essa última traduzida em uma marca que no caso dos CRs apresenta-se como ressocialização.

Tal ressocialização pode ser tanto mais definida enquanto uma marca, na medida em que se observa a forma de constituição desses CRs e os critérios para a “inclusão” dos presos nesses locais. Em primeiro lugar, a própria frouxidão dos requisitos exigidos para que uma entidade da sociedade civil celebre tais convênios com o Estado, em razão, é certo, de uma intencional displicência legal ${ }^{140}$, já traz em si os riscos do desvirtuamento da finalidade pretendida, a reinserção social. Nesse sentido, a suspeição ${ }^{141}$ que tem recaído sobre o funcionamento de muitas dessas unidades e até as denúncias sobre irregularidades em relação às entidades administradoras, como à própria gestão dos CRs em si, consistem antes em sintomas daquilo que os CRs realmente representam: experiências primárias de privatização de serviços públicos, apresentadas sob o rótulo de participação comunitária em presídios.

A artificialidade ainda do caráter ressocializador do tratamento dispensado em referidos locais se revela pela rigorosa seleção estabelecida dos presos para lá encaminhados. Ou seja, sob a condição irrevogável de atuar tão-somente sobre uma clientela “especial” do sistema, os CRs clamam seus sucessos “reintegradores” junto a indivíduos tradicionalmente detentores de privilégios na prisão ou cujo comportamento já fora normalizado por ela. Os CRs acabam por operar, assim, no reforço à partilha entre os

${ }^{140}$ O Decreto 45.403/00 que autoriza a celebração de convênios com a SAP para co-gestão dos CRs estabelece como requisito apenas que se tratem de entidades privadas, sem fins lucrativos, que tenham por finalidade estatutária auxiliar as autoridades judiciárias e policiais do município, em todas as tarefas ligadas à readaptação dos sentenciados, presidiários e egressos dos presídios, tendo por objeto a prestação de serviços inerentes à proteção e assistência carcerária (art. $1^{\circ}$ ). Não se observa, assim, qualquer outra exigência que se refira, por exemplo, ao tempo de constituição da entidade.

${ }^{141}$ A Pastoral Carcerária vem já há algum tempo questionando a legitimidade de tais organizações, havendo informações que algumas delas seriam constituídas por familiares de funcionários do sistema com o fim específico de administrar os CRs. Constituiriam-se e funcionariam segundo as mesmas finalidades de empresas privadas, ou seja, a servir de fonte de renda a seus "diretores”. A nova gestão da SAP que sucedeu Nagashi em junho de 2006 tem propagado a existência de supostas irregularidades nesses convênios, rescindindo inclusive alguns contratos. Essa medida, contudo, não deixa também de ter um caráter político, em razão da ostensiva oposição da atual gestão a Nagashi. 
recuperáveis e os não recuperáveis no universo da prisão, a qual Nagashi freqüentemente invoca para justificar a diretriz de sua política. Como um verdadeiro fosso aberto entre a população prisional, se revela ainda como o fundamento das promessas e ameaças a ela dirigidas: aos recuperáveis, a redenção dos CRs; aos irrecuperáveis, a exclusão do RDD. Entre ambos, no entanto, a grande massa de encarcerados permanece em meio às deficiências estruturais e à violência generalizada de um sistema que já não expressa mais os dilemas de outrora quanto às finalidades de sua intervenção e ao destino de sua clientela.

\section{A NOVA LEP DE 2003: A SOBERANIA ADMINISTRATIVA ${ }^{142}$ E O NOVO ESTATUTO JURÍDICO DO PRESO}

Na minha opinião, é totalmente necessário que o diretor de uma prisão sobretudo se este experimenta um novo método disciplinar - seja investido de um poder absoluto, o que entre nós, num Estado democrático, é praticamente impossível (...) para reformar e conduzir um cárcere é necessário concentrar nas mãos de um único indivíduo todo o poder e todas as responsabilidades.

(depoimento de Sr. E. Lynds, diretor da Penitenciária de Sin-Sing e ex-diretor de Auburn, EUA, em entrevista a A. Tocqueville e G. Beaumont, 1831 ${ }^{143}$ ).

Tão logo o RDD começara a ser aplicado no Estado de São Paulo, seu pretenso e proclamado sucesso no combate ao crime organizado dentro dos presídios, pelo isolamento de seus principais líderes, despertou, de modo gradativo, a atenção de diversos segmentos.

Na esfera da administração pública, não apenas os demais Estados mostraram-se desejosos em implantar simulacros do RDD, como a própria União se interessaria pelo regime, passando a ver na idéia de normatizá-lo uma alternativa política ao problema das facções criminosas nas prisões, o que a desoneraria, em parte, da persistente cobrança política pela construção de presídios federais de segurança máxima.

\footnotetext{
${ }^{142}$ Expressão extraída do livro de Melossi e Pavarini (2006) empregada pelos autores para se referirem ao modelo de prisão existente em Auburn, no qual o administrador concentra um grande poder com relação à dinâmica prisional.

143 Conforme nota 17 do cap. I (Melossi e Pavarini, 2006).
} 
À época, então, ainda sob o mandato de Fernando Henrique Cardoso na Presidência da República, correligionário do então governador de São Paulo Geraldo Alckmin, teriam ocorrido as primeiras aproximações entre o Ministério da Justiça e a $\mathrm{SAP}^{144}$, nas quais o Ministério teria manifestado o interesse em que a Secretaria disponibilizasse seu know how sobre essa técnica disciplinar (o RDD), a fim de adotá-la como uma política nacional.

Para Nagashi, no entanto, já àquele momento, era de pouca relevância que o RDD viesse a ser também previsto na legislação federal, uma vez que, como ele mesmo afirmava constantemente, desde que o regime fora implantado, não sofrera qualquer decisão contrária por parte da Justiça Criminal ${ }^{145}$, em nenhuma instância, o que segundo ele consagrava a legalidade e a constitucionalidade de sua Resolução. Além disso, submeter a matéria a um processo legislativo poderia trazer riscos quanto ao exato conteúdo de sua aprovação. Ou seja, o ex-Secretário temia, em verdade, que algumas disposições da Resolução que vigiam até o momento sem qualquer impugnação judicial, pudessem vir a ser alteradas, como o que de fato ocorreu quando da reforma da LEP em 2003, com a introdução da exigência de autorização judicial para ingresso de presos no RDD, autorização essa que inexistia na Resolução 26/01.

No entanto, Nagashi tinha pretensões ainda muito maiores quanto ao destino da execução penal no país que a simples introdução de um regime disciplinar diferenciado. E foi com vistas a essas futuras pretensões que ele deu início às intensas negociações que levariam quase dois anos para se realizarem no plano da Lei 10.792/03.

\footnotetext{
${ }^{144}$ A existência desses contatos foi relatada pela defensora pública Carmen Silvia de Moraes Barros em entrevista realizada em 06/07/2006. Carmen esclareceu que o próprio Secretário Nagashi teria narrado tal conversa na ocasião em que recebera um grupo de defensores públicos atuantes na execução penal em seu gabinete para apresentar parte do projeto que redundaria na Lei 10.792/03 e solicitar o apoio institucional do grupo, que, como será discutido adiante, embora discordante quanto ao RDD, apoiaria as disposições sobre o fim dos exames criminológicos.

${ }^{145}$ Somente em agosto de 2006 a Justiça paulista se pronunciaria contrariamente ao RDD. Numa decisão bastante polêmica e contundente, a $1^{\text {a }}$ Câmara Criminal do TJ/SP declararia a inconstitucionalidade e a ilegalidade do RDD, concluindo que: "não é aceitável, pois, a conivência de magistrados, fiscais da lei, advogados, enfim, operadores do direito, com tamanha barbárie. Não se pode admitir que estes, diante de tanta ilegalidade, quer por ação quer por omissão, se convertam em aparato legitimador da atuação abusiva da administração. $O$ RDD é um desrespeito à Constituição, à lei, aos cidadãos deste país, enfim, à nossa inteligência por representar uma pena cruel, vedada constitucionalmente" (Processo $\mathrm{n}^{\circ}$ 978.305.3/0-00). Essa decisão teve grande repercussão, representando um marco simbólico, mas que acabou por não redundar, contudo, na remoção do RDD do preso autor do Habeas Corpus motivador da decisão, tendo em vista a existência de outras decisões que autorizavam sua manutenção. Em 18 de setembro de 2006, o presidente do TJ/SP, Celso Limongi, também de forma surpreendente e polêmica, conferiu entrevista ao Jornal Folha de S. Paulo na qual afirmou ser pessoalmente contrário ao RDD, entendendo-o como pena cruel e declarando: "não acho que o Estado possa descer ao próprio nível de um criminoso". (Presidente do TJ de SP critica polícias e presídio "cruel", Jornal Folha de S. Paulo, Caderno Cotidiano, 18 de setembro de 2006).
} 
A idéia do ex-Secretário era propiciar mecanismos que conferissem maior concentração de poder decisório acerca da dinâmica do cumprimento da pena nas mãos da Administração, de modo que a ela competisse a definição sobre as transferências de regime e, em última análise, a decisão sobre a manutenção ou a saída antecipada de um preso no sistema. Entretanto, para que tal plano se concretizasse, havia um verdadeiro grande óbice: a jurisdicionalização da execução penal, prevista na legislação desde $1924^{146}$ e sistematicamente consagrada no ordenamento em 1984.

Nagashi, no entanto, não atacaria num primeiro momento a jurisdicionalidade da execução, o que teria sido politicamente mais árduo e desastroso. Ele se voltou, em verdade, contra um ponto extremamente polêmico na questão prisional, que constitui desde há muito um campo de disputa no interior do funcionamento da prisão e do saber que sobre ela se produz: a existência dos laudos e exames criminológicos realizados pelas Comissões Técnicas de Classificação - CTCs, cujo parecer constituía um dos requisitos à concessão de benefícios prisionais (como a progressão de regime e o livramento condicional).

Em verdade, desde o início de sua gestão, o ex-Secretário deu consecução a uma política de desmonte do aparato institucional criminológico existente ${ }^{147}$, responsável em tese pela classificação, triagem, acompanhamento e avaliação dos presos, composto por um corpo técnico de psicólogos, assistentes sociais e psiquiatras encarregados dessas atividades. Em 2 de janeiro de 2002, através do decreto $n^{\circ}$ 46.483, Nagashi finalmente extinguiria o Centro de Observação Criminológica - COC, órgão criado à época da entrada em vigor da LEP de 1984, em substituição ao antigo Instituto de Biotipologia Criminal, justamente para a produção desse saber científico na prisão.

Segundo as disposições da LEP de 1984, o COC deveria ser instalado em cada presídio a fim de desempenhar a função de acompanhamento técnico da pena, a partir da realização de todos os exames referentes ao preso e à execução de sua pena, desde o exame de classificação inicial até os pareceres que instruíram benefícios. Na prática, o COC da Capital - único existente em todo o Estado - realizava apenas alguns exames para aqueles presos considerados mais perigosos e, via de regra, por solicitação judicial, sendo

\footnotetext{
${ }^{146}$ Considerando-se a legislação que instituiu o instituto do livramento condicional (Decreto 16.665 de 1924), por ter condicionado sua concessão à autorização judicial, como marco de previsão da participação jurisdicional no cumprimento da pena no país.

${ }^{147}$ Nagashi, já em 2000, iniciara uma reestruturação junto ao Departamento de Saúde do sistema, que seria extinto nesse mesmo ano, e no próprio Centro de Observação Criminológica - COC, demitindo seu diretor e transferindo outros profissionais em meados de 2001.
} 
conhecido pelo número elevado de pareceres contrários que emitia em relação aos benefícios solicitados pelos presos. Operava ainda como uma espécie de "seguro” para os presos jurados de morte e com necessidade de proteção especial, inclusive policiais civis que não tinham como ser recolhidos em presídios próprios.

A extinção, à primeira vista inesperada, do COC, foi interpretada à época pelos operadores da área apenas como mais uma medida de readequação administrativa e ainda sintomática das deficiências e precariedades na estruturação dos serviços oferecidos pela SAP, tendo representando também, segundo alguns, um “retrocesso"148, mas não como o prenúncio de uma ruptura ou um de deslocamento com relação aos eixos que haviam sido definidores da LEP e, enfim, da política penitenciária adotada a partir de 1984.

O fato ainda de que nenhum outro órgão do gênero houvesse sido anunciado para cumprir as funções que competiam ao $\mathrm{COC}^{149}$ denotou que, para além de se extinguir um mero estabelecimento penal, Nagashi atacara um conceito e uma natureza de intervenção sobre o preso até então existente na dinâmica prisional.

Dando prosseguimento aos seus planos de redefinição da execução penal no país, Nagashi formularia algum tempo depois o projeto de lei federal com vistas a suprimir a previsão legal de realização dos laudos ou pareceres criminológicos do ordenamento jurídico, sendo duas as ordens de argumentos mobilizados em sua proposta. A primeira e menos importante dizia respeito à falta de estrutura das CTCs no país, à precariedade de seu funcionamento e à má qualidade de seu trabalho, resultando o teor dos laudos realizados em meras repetições e avaliações superficiais sobre o preso.

O segundo argumento, contudo, se referia à retomada de uma discussão ontológica a respeito desses laudos e da existência de tais Comissões dentro da prisão. Traduzindo-se numa preocupação sobre a legitimidade e a importância desse tipo de saber na definição dos destinos de cada preso, a SAP expressava, agora, uma ordem de preocupações acerca da “subjetividade” intrínseca a esse tipo de parecer e dos óbices que o mesmo costumava

\footnotetext{
148 Quando o processo de desmonte do COC foi iniciado, despertou algumas críticas, sobretudo dos promotores de justiça da VEC da Capital, que viam na ação de Nagashi um instrumento para que se libertasse criminosos perigosos antecipadamente. Promotores querem evitar fim de centro criminológico. Jornal $O$ Estado de S. Paulo, 15 de novembro de 2001. Percebe-se que a discussão, já à época, esteve polarizada entre a conferência de maior ou menor expectativas de liberdade antecipada ao preso, estando a Defensoria Pública no pólo oposto ao MP, apoiando essas iniciativas de Nagashi, o que será demonstrado adiante.

149 No local acabou sendo criado o Centro Hospitalar do Sistema Penitenciário, reunindo as diferentes unidades de saúde do sistema.
} 
trazer quanto aos prognósticos de recuperação dos reclusos. Desse modo, Nagashi definiria sua posição a respeito:

Eu acho que está verdadeiramente errado. Esse exame acaba tentando entrar no íntimo das pessoas, seja por meio de exame psiquiátrico, psicológico, tentam vasculhar o que está dentro da cabeça da pessoa (...) Ou seja, o laudo acho que está errado por princípios (...) Por isso é que se propôs a eliminação de todos esses exames por algo objetivamente constatado que é o comportamento; comportamento é algo que se constata objetivamente, quem tem bom comportamento, reúne mérito para progredir, quem não tem bom comportamento, não reúne méritos para progredir. ${ }^{150}$

Questionado se a mesma subjetividade presente nos pareceres da CTC não poderia ser encontrada no conceito de mérito e de boa conduta carcerária, bem como sobre o fato de se estar depositando um grau excessivo de poder nas mãos de quem atribui esse mérito, ou seja, dos agentes de segurança e disciplina, o ex-Secretário reagiu incisivamente:

Comportamento não tem subjetividade nenhuma pois, se não houver prática de faltas, a conseqüência é que o comportamento é bom; se houver prática de falta, a conclusão é de que o comportamento não é bom. ${ }^{151}$

Resumida a essa simples operação lógica, o que escapava (oportunamente) a tal proposta, era justamente a segunda parte da pergunta formulada ao ex-Secretário que permaneceu sem resposta: o fato de que ela (re)inaugurava uma dinâmica de poder no interior da prisão na qual a figura do carcereiro emergia como central na estrutura funcional e normativa da execução penal. Como já discutido, essa centralidade é também dependente do estatuto jurídico a que se atribua ao preso, ou seja, quanto mais precisa for a destituição do indivíduo encarcerado como sujeito de direitos e, do mesmo modo, mais cerceado for seu acesso à jurisdição, maiores serão as chances da ordem disciplinar e de toda sua tecnologia de poder prevalecerem no universo da prisão, percorrendo-se, nesse caso, o caminho inverso àquele tomado pela reforma de 1984.

Nesse sentido, é certo que os laudos e exames criminológicos acabavam por desempenhar um papel essencialmente simbólico na composição de forças e representações existente no universo prisional. Assim, não teria sido a polêmica que se encerrava sobre a

\footnotetext{
${ }^{150}$ Entrevista realizada em 31/08/2006.

151 idem
} 
persistência de um conteúdo positivista na exigência dos laudos o que de fato esteve na base do projeto que objetivou (e logrou) sua eliminação. O que realmente estava em jogo na proposta pelo fim dos laudos criminológicos era o local estratégico ocupado por esse saber técnico na prisão, na medida em que ele operava uma inevitável partilha de poder no interior do cárcere, pela qual a ordem disciplinar passava a sofrer limitações no seu exercício pleno. É nessa perspectiva que a proposta de Nagashi deve ser inserida para que então seja possível compreender o que ela realmente representou: um passo intermediário na consolidação de um projeto de excelência disciplinar e de desconstrução do sujeito de direitos na prisão, situado entre a instauração do RDD e a meta final que seria alcançada pela desjurisdicionalização da execução penal.

É nesse declarado sentido que o próprio autor dos projetos, Nagashi Furukawa, pôde, já não mais à frente da Secretaria, descrever o conjunto de suas iniciativas de mudança legislativa. Quando perguntado se a desjurisdicionalização, que foi a última (embora até aqui ainda frustrada) proposta de reforma da execução penal que empreendeu, consistiria no passo subseqüente e derradeiro de sua política reformadora, sua confirmação foi imediata:

Sim. Pois com a mudança pela Lei 10.792/03 tirando o parecer da CTC, deixou de existir aquela atividade de apurar se determinado preso reúne ou não condições de obter algum direito, porque essa é uma tarefa que competia ao juiz exercer (...) Hoje não há mais uma avaliação jurisdicional necessária para isso. É uma avaliação puramente objetiva (...) numa atividade puramente objetiva como essa não há necessidade nenhuma do Judiciário estar fazendo isso. ${ }^{152}$

Se o desenrolar dos fatos pôde demonstrar os desígnios dessa política, é certo, contudo, que eles não se apresentaram evidentes desde sempre. Assim, foi com bastante habilidade que a SAP se mobilizou para conquistar os apoios necessários à sua proposta, tendo tido grande êxito junto a importantes setores atuantes e formadores de opinião no âmbito da execução penal, em grande parte os mesmos que se opunham ainda veementemente ao RDD.

Centrando-se no argumento de que a exigência dos laudos operava em verdade como um óbice para o acesso aos direitos e benefícios prisionais pelo preso e que, portanto,

\footnotetext{
152 Entrevista realizada em 31/08/2006.
} 
era um mecanismo que agravava sua pena, a proposta de Nagashi conquistou irrestrito apoio entre os grupos e entidades defensoras dos direitos dos presos e do órgão encarregado pela Defensoria Pública. De fato, referidos atores conheciam muito particularmente, primeiro, a precariedade dos laudos e, segundo, o aproveitamento ideológico que era promovido pelos juízes da execução, o que já foi inclusive demonstrado empiricamente (Teixeira e Bordini, 2004). Sob essa única perspectiva, a proposta da supressão dos laudos foi recebida com simpatia e apoio por parte desses grupos, na crença, por certo, de que tal supressão redundaria enfim num aumento no número de benefícios concedidos e num desafogamento do sistema, o que, entretanto, acabou não se verificando, senão o contrário, em razão de um acirramento ainda maior na atuação do Ministério Público e do Judiciário no que se refere à garantia dos direitos dos presos a partir de então ${ }^{153}$.

Pelo projeto de lei 5.073/01 e seus substitutivos, a SAP formularia três ordens de pretensões: i) a inclusão no RDD na LEP e seu disciplinamento nos mesmos termos do que vinha sendo aplicado no Estado de São Paulo; ii) o fim da previsão dos pareceres técnicos para concessão de benefícios, também no âmbito da LEP; e iii) a modificação do Código de Processo Penal para inserir o chamado interrogatório virtual de réus presos, sem a presença física do juiz, promotor e defensor, o que em verdade também já vinha sendo praticado em São Paulo, pese o ferimento a diversos princípios e garantias legais como a ampla defesa e o contraditório.

Dessas três pretensões, é possível dizer que Nagashi saiu plenamente vitorioso em apenas uma delas: a extinção dos laudos. Nos demais, não obstante a promoção de um

\footnotetext{
153 O que tem se verificado após a aprovação da Lei 10.792/03 é a recorrente exigência de elaboração laudos na instrução dos benefícios por parte dos juízes e promotores de execução do Estado de São Paulo, mesmo em confronto à nova Lei que os suprimiu, o que gerou protestos não apenas da Defensoria Pública como da Administração Penitenciária que vinha relutando em realizá-los. Até agora o Judiciário e o Ministério Público têm ganhado a disputa, uma vez que conseguiram um pronunciamento do STJ reconhecendo a legitimidade de tal exigência. Essa postura, no entanto, apenas traduz um jogo de forças com a Administração e uma relutância cada vez mais exarcebada em conceder direitos de progressão de regime aos presos, bem como tem se revelado desastrosa para o funcionamento do sistema, uma vez que a SAP praticamente desmontou as equipes e o pessoal técnico encarregado desses pareceres, o que torna demais moroso e custoso o procedimento de realização dos exames.
} 
intenso lobby político junto ao Congresso Nacional, o resultado obtido não correspondeu em estritos termos às suas expectativas.

No que toca ao RDD, após mobilização de um grupo de defensores públicos de São Paulo junto à Comissão de Constituição e Justiça do Senado, a autorização judicial passaria a ser prevista no projeto como requisito necessário para o ingresso no regime, o que representou uma derrota significativa na lógica da dinâmica disciplinar instaurada por Nagashi pelo RDD, por restringir em muito a discricionariedade do administrador prisional. No que se refere ao interrogatório on line, outros substitutivos já haviam vedado tal hipótese, permitindo-se a realização do interrogatório na prisão tão-somente com a presença do juiz e defensor.

A Lei 10.792 seria então aprovada em $1^{\circ}$ de dezembro de 2003, consagrando a prática de exceção do RDD no ordenamento jurídico ${ }^{154}$ e erigindo os dispositivos disciplinares à categoria central e definidora da dinâmica prisional. Ironicamente, o relator do projeto que seria aprovado na Câmara como o texto final da Lei seria o Deputado Ibrahim Abi-Ackel, o mesmo que, quando relator da CPI do Sistema Prisional de 1976 e Ministro da Justiça do governo Figueiredo, destacara-se como figura de especial importância na elaboração e promulgação da LEP de 1984. Decorridos quase vinte anos da aprovação dessa Lei, estava novamente ele à frente de um processo de formalização legal de já transmudadas práticas punitivas, só que dessa vez o processo deflagrava o mais contundente desmonte dos princípios e orientações dos quais fora ele, um dia, um importante defensor.

Ainda que não a partir dos estritos termos propostos, a aprovação da reforma da LEP em 2003 não pôde deixar de representar uma importante vitória da política que Nagashi empreendera, à frente da SAP, desde o início de sua gestão, tendo simbolizado ainda a consolidação de uma diretriz adotada para a questão carcerária e um passo decisivo para que seu mais ambicioso projeto para a execução penal fosse proposto: a desjurisdicionalização.

Assim, já em meados de 2005, a SAP/SP elaboraria uma proposta de nova reforma legislativa federal visando à alteração de dois dispositivos da LEP referentes à atividade

154 Embora a inserção da autorização judicial tenha representado uma medida em princípio de maior preservação de direitos, outras previsões aprovadas na Lei levaram o RDD a uma condição de maior crueldade e suspensão de direitos, como no caso da possibilidade de prorrogação praticamente indeterminada do prazo de internação (assemelhando-se nesse aspecto ao regime que existia em Taubaté). 
jurisdicional da execução. Mediante uma justificativa apresentada como um "estudo científico” intitulado Administracionalizar os benefícios da execução penal, a gestão Nagashi tentava forjar uma nova proposta para a área, inscrevendo-a ainda como um desdobramento lógico das reformas anteriores, como uma etapa natural e inevitável da execução penal. Eis um trecho da justificativa:

Ora bem, a administracionalização dos benefícios insere-se de forma congruente no resgate do valor do que se faz (e não do que sente, pense ou pretende) o preso durante a execução de sua pena. O administrador, observando a conduta externa de seus administrados na unidade prisional, mediante critérios preestabelecidos e conhecidos de todos, está plenamente apto, se for o caso, a aboná-la e deferir requerimento de progressão de regime, livramento condicional, indulto ou comutação de pena. ${ }^{155}$

Tal pragmatismo, de modo já recorrentemente simplista, derrubava de uma só tacada todos os disputados princípios liberais do devido processo legal, do direito à jurisdição e, por fim, da constituição do sujeito de direitos no espaço da prisão. Em nome da eficiência, da celeridade, e, claro, das “boas intenções” com relação ao destino da massa carcerária, iniciava-se a costura política de Nagashi pelo fim da jurisdicionalidade na execução penal.

A proposta de projeto viria a ser então “aprovada por maioria de votos” entre aqueles diretamente beneficiados pelo seu conteúdo: os Secretários de Justiça e Administração Penitenciária, mediante uma reunião do CONSEJ - Conselho Nacional de Secretários de Estado da Justiça, Direitos Humanos e Administração Penitenciária realizada em 10 de novembro de 2005. A partir de então, a SAP de São Paulo passaria a empreender nova cruzada em busca de apoios e sustentação política para a proposta.

No entanto, dessa vez Nagashi não receberia o apoio daqueles mesmos segmentos que encamparam o projeto anterior pelo fim dos laudos criminológicos. Revelava-se um tanto mais árdua a tarefa de convencer tais atores de que uma proposta que subtraía o direito de acesso à jurisdição dos indivíduos encarcerados poderia, ao mesmo tempo, acarretar-lhes mais benefícios, assim como a justificativa do projeto sugeria. Mesmo os mais desiludidos com um sistema de justiça criminal especialmente empenhado na

${ }^{155}$ Administracionalizar os benefícios da execução penal. Proposta de lei federal e justificativa elaborada pela SAP/SP e apresentada em 10/12/2005 em reunião do Conselho Nacional de Secretários de Estado da Justiça, Direitos Humanos e Administração Penitenciária - CONSEJ. 
produção da delinqüência, como o brasileiro, não conseguiam enxergar com bons olhos o projeto da desjurisdicionalização de Nagashi.

Em 16 de fevereiro de 2006, uma audiência pública promovida pelo Conselho Nacional de Política Criminal e Penitenciária - CNPCP seria então realizada na Assembléia Legislativa de São Paulo contando com a participação direta de entidades, movimentos de defesa dos direitos dos presos, militantes dos direitos humanos e juristas, tendo como desfecho um amplo repúdio à referida proposta e a divulgação de dois manifestos nesse sentido ${ }^{156}$.

Por outro lado, as próprias condições políticas enfrentadas pelo ex-Secretário Nagashi começavam a se mostrar adversas neste momento, com o licenciamento do governador Alckmin, em razão do contexto nacional definido por um ano eleitoral que dificultaria amarrações entre partidos de oposição e, por derradeiro, em virtude dos próprios acontecimentos deflagrados a partir de maio de 2006 através dos atentados do PCC, que culminariam com a mais intensa crise na segurança pública já assistida e o afastamento de Nagashi em junho do mesmo ano.

No entanto, também é certo que as condições fáticas e, sobretudo políticas, advindas de um contexto mundial marcado pelo declínio de vários pressupostos que um dia estabeleceram-se em torno da prisão - o episteme da privação na explicação do crime, a ressocialização, a figura do sujeito de direitos no cárcere - teria sido propícia para que as transformações aqui relatadas adviessem e consolidassem novos padrões e formas de intervenção que ainda estão sendo definidos e configurados, e cujas implicações serão decisivas para o destino de uma definição de Estado de direito a qual a modernidade foi tributária e a pós-modernidade parece corroer cada vez mais através das práticas de exceção.

Nesse sentido, a proposta da desjurisdicionalização da execução penal, antes de poder ser definida como um devaneio de um administrador prisional que ansiava pela ampliação de seu poder, se apresenta como uma possibilidade cada vez mais plausível no tratamento da questão carcerária, constituindo ainda, na correta acepção de seu proponente,

\footnotetext{
${ }^{156}$ Um deles foi encabeçado pelo Fórum Grupo de Estudos e Trabalho Mulheres Encarceradas tendo como subscritores a Associação Juízes para a Democracia, o Centro Santo Dias de Direitos Humanos, a Pastoral Carcerária, entre outras organizações. O outro foi elaborado por entidades de juristas ligados ao tema encabeçados pelo Movimento Antiterror Penal, o qual também advogados destacados subscreveram, inclusive autores do Código Penal de 1984.
} 
um desdobramento mais do que possível das mudanças a que a prisão vem sofrendo ao longo dos últimos anos.

É por isso que a frase disposta na epígrafe desta última seção, proferida pelo exdiretor da prisão de Auburn/EUA, em 1831, louvando a soberania administrativa como medida imprescindível ao sucesso de seu inovado método disciplinar e, para além, reconhecendo que a existência de um Estado democrático constitui um verdadeiro óbice a esse sucesso, soa mais atual do que nunca, quase dois séculos depois. 


\section{CONSIDERAÇÕES FINAIS}

Repensar o papel da prisão na atualidade em sociedades que vivenciaram a experiência do Estado providência, a amplitude da norma salarial e, sobretudo, a extensão de direitos civis e sociais, exigiu, dos autores que mais se debruçaram sobre essa realidade, um esforço em demarcar as rupturas, os deslocamentos e daí as adaptações engendradas, usando o termo de Garland (2005), que levaram à reformulação das categorias que compõem o cenário das práticas punitivas e que lhe conformam significado.

Estender essa perspectiva de análise para um modelo de sociedade que não experimentou o estado de bem-estar social em qualquer dos seus termos e que traz características particularíssimas atreladas ao seu processo histórico, foi assim parte do desafio e da proposta colocados neste trabalho. Desse modo, proceder a uma análise das políticas criminais e penitenciárias empreendidas contemporaneamente no Brasil, impôs a prévia identificação dos pontos de ruptura e dos deslocamentos na forma de conceber a questão criminal, a partir das experiências que, se não instauraram, ao menos foram portadoras das promessas do modelo da social democracia, e, da mesma forma, também das promessas de um outro modelo de intervenção penal e de um outro modelo de prisão.

A radiografia do sistema penal brasileiro contemporâneo, tendo como referência, sobretudo as práticas que compuseram a política penitenciária paulista nas últimas décadas, pôde refletir como sua atuação esteve relacionada e implicada em contextos sociais e políticos mais amplos. Assim, foi no período compreendido pela redemocratização que as percepções do preso como sujeito de direitos e a idéia de direitos humanos no cárcere puderam tardiamente encontrar previsão no âmbito de uma nova legislação criminal que se instaurava, mesmo quando tais percepções e conceitos já se encontravam em decadência em outras partes do mundo e eram suplantados por novas formulações advindas de outras racionalidades já predominantes.

Foi nesse período ainda que, não obstante a permanência das deficiências estruturais e da subcultura de violência e arbítrio prevalecentes nas prisões brasileiras, puderam ser identificadas as primeiras (e breves) experiências emancipatórias no cárcere, centradas, em especial, na perspectiva do reconhecimento da existência política do preso e da negação da prisão como um espaço do contradireito, e expressas nas medidas de humanização das prisões do governo Montoro (1983-86). A vulnerabilidade dessas ações e 
as múltiplas fontes e formas de oposição que sofreriam, levariam não apenas ao declínio de tal orientação política, mas ao seu completo avesso, bem como à deturpação de seu registro histórico.

No período imediatamente posterior à promulgação da Constituição “cidadã” de 1988, a recém-instalada experiência democrática apresentaria já seus primeiros sinais de fragilidade diante das reações de uma oligarquia jamais abatida, sendo as eleições presidenciais de 1989 a marca desse momento de inflexão democrática. Foi nesse momento também que as promessas de uma política criminal progressista que a legislação de 1984 anunciara, começariam a ruir, promovendo-se a partir de então sua gradativa derrogação.

Assim, já no início dos anos 90, quando então se assistiria ao declínio do ideal ressocializador e à ascensão de medidas legais supressoras de direitos dos acusados e presos, implantadas sob o signo da urgência e da exceção, simbolizadas pela Lei dos Crimes Hediondos, foi também o momento a partir do qual as políticas penitenciárias assumiriam uma feição de maior truculência, através de práticas de acentuada de violência institucional, cujo ápice esteve representado no episódio do Massacre do Carandiru, em 1992.

Para além, contudo, das medidas que importariam no extermínio de centenas de indivíduos encarcerados entre os anos de 1987-1994, foi também nesse período que se assistiu ao incremento da tortura e do arbítrio nos espaços preferenciais de exceção dentro do sistema penitenciário, concebidos numa zona de indistinção entre a lei e a norma, para operarem a lógica da excelência disciplinar. De modo bastante sintomático, seria justamente em tais espaços e sob essa consagrada orientação política que a organização criminosa PCC surgiria, em 1993, e se fortaleceria para além do próprio sistema carcerário.

Se havia alguma lição a ser tirada, certamente os desdobramentos históricos e as ações empreendidas pelas gestões que se seguiram mostram que muito pouco se aprendeu, ou ainda, sugerem que não se trata mais de um problema que deva ser enfrentado nos marcos de um Estado de direito. Esse é, em suma, o sentido também que pode ser extraído da análise aos autores aqui trabalhados que discutiram e refletiram, de algum modo, o tema em pauta (Agamben, 1998; Garland, 2005 e Foucault, 2004), de que o enfrentamento da questão criminal, como de resto de outras questões da política contemporânea, não passará mais pelas categorias e pelos modelos que um dia compuseram o jogo de referências (Telles, s.d.) e o campo conceitual dos quais a modernidade foi tributária. 
Nesse sentido, foi, a partir de 1999, através do conjunto de ações promovidas no âmbito da política penitenciária paulista, que a nova racionalidade informadora das noções sobre crime e punição, instalada com o fim do welfarismo penal, se apresentaria mais precisamente neste estudo, sobretudo pelo modo como passou a conformar as novas representações sobre a nova finalidade da prisão (a incapacitação), a nova figuração do preso (homo sacer), e, mais importante, o instrumento para promovê-las, a exceção.

Ao sofisticar um aparato de excelência disciplinar, com a criação do RDD, erigiu-se uma experiência que era antes obscura, marginal e quase constrangedora a um estatuto de legalidade, legitimidade e eficiência. Não obstante o conteúdo em si do regime de adaptação penitenciária do "Piranhão” e das masmorras brasileiras de modo geral, de um lado, e do RDD, de outro, ser rigorosamente o mesmo - sobreprivação de direitos, torturas diversas, castigos corporais, isolamento contínuo - o que garantiu a generalização do último foi sem dúvida o modo (o invólucro) em que ele foi apresentado, e, sobretudo, sua inscrição, a partir desse momento, numa racionalidade que não mais se constrange na produção da vida nua, pois, em suma, é ela que em si promove também o apagamento da figura moral do delinqüente.

Do mesmo modo, as demais medidas pretendidas e enfim realizadas ou preconizadas pela gestão de Nagashi Furukawa, como a extinção dos laudos criminológicos e a desjurisdicionalização da execução da pena, alinharam-se com bastante nitidez às novas concepções formuladas no campo das práticas punitivas, permitindo-se ainda que através delas se reflita, uma vez mais, sobre suas implicações para além do sistema penal. 


\section{BIBLIOGRAFIA E FONTES CONSULTADAS}

\section{Bibliografia}

ADORNO, Sérgio; CASTRO, Myriam M. P. de, “A Pobreza colonizada”. In: Serviço Social e Sociedade, $\mathrm{n}^{\circ}$ 17, abril de 1985.

ADORNO, Sérgio; FISHER, Rosa Maria, Análise do Sistema Penitenciário do Estado de São Paulo: o gerenciamento da marginalidade social. São Paulo: Relatório de Pesquisa. CEDEC, 1987.

ADORNO, Sérgio. "Discriminação racial e justiça criminal em São Paulo". In: Novos Estudos Cebrap n ${ }^{\circ}$ 3. nov-1995.

A gestão urbana do medo e da insegurança. Violência, Crime e Justiça Penal na

Sociedade Brasileira. Tese apresentada para o concurso de livre-docência junto ao Departamento de Sociologia da FFLCH/USP em março de 1996.

AGAMBEN, Giorgio. O Poder soberano e a vida nua. Homo sacer I. Lisboa: Editorial Presença, 1998.

Estado de Exceção. São Paulo: Boitempo, 2004.

ALVAREZ, Marcos César. Bacharéis, Criminologistas e Juristas: Saber Jurídico e a Nova Escola Penal no Brasil. São Paulo: IBCCRIM, 2003.

ALVIM, Rui Carlos Machado. O Trabalho Penitenciário e os Direitos Sociais. São Paulo: Editora Atlas, 1991.

ANDERSON, Perry. "Balanço do Neoliberalismo". In: Pós-Neoliberalismo. As Políticas Sociais e o Estado Democrático. (org. Emir Sader e Pablo Gentili), 2ªed. Rio de Janeiro: Editora Paz e Terra, 2003, p. 9-23.

ANTUNES, Ricardo, Os Sentidos do Trabalho. Ensaio sobre a afirmação e negação do trabalho. 6a ed. São Paulo: Boitempo Editorial, 2002.

BARATTA, Alessandro. Criminologia Crítica e Crítica do Direito Penal. Introdução à Sociologia do Direito Penal. $2^{\mathrm{a}}$ ed. Rio de Janeiro: Freitas Bastos Editora, 1999.

BAUMAN, Zygmunt. Globalização e Conseqüências Humanas. Rio de Janeiro: Jorge Zahar Editora, 1999. . Vidas Desperdiçadas. Rio de Janeiro: Jorge Zahar Editora, 2005.

CALDEIRA, César. “Caso do Carandiru: um estudo sócio-jurídico. $1^{\text {a }}$ parte”. In: Revista Brasileira de Ciências Criminais, São Paulo: Editora RT. n 29, jan-março de 2000.

CALDEIRA, Teresa P. R. Cidade de muros. Crime, segregação e violência em São Paulo. $2^{\mathrm{a}}$ ed. São Paulo: Edusp, Editora 34, 2003.

CASTEL, Robert. A Ordem Psiquiátrica. A Idade de Ouro do Alienismo. $2^{\mathrm{a}}$ Ed. Rio de Janeiro: Graal, 1991.

As metamorfoses da questão social. Uma crônica do salário. São Paulo: Editora Vozes, 1999. 
CHALHOUB, Sidney. Trabalho, lar e botequim: o cotidiano dos trabalhadores do Rio de Janeiro da Belle Époque. São Paulo: Brasiliense, 1986.

CHRISTIE, Nils. A indústria do controle do crime: a caminho dos Gulags em estilo ocidental. Rio de Janeiro: Companhia Editora Forense, 1998.

CORREA, Marisa. As ilusões da liberdade: a escola Nina Rodrigues e a Antropologia no Brasil. Tese (Doutorado em Antropologia) - Departamento de Antropologia FFLCH/USP,1982.

COSTA, Jurandir Freire. Ordem médica e norma familiar. Rio de Janeiro: Graal, 1979.

DELEUZE, Gilles. Conversações. São Paulo: Editora 34, 1992.

DONZELOT, Jacques. A Polícia das famílias. 3ª ed., Rio de Janeiro: Graal, 2001.

DURKHEIM, Émile. Da divisão do trabalho social. 2a ed. São Paulo: Editora Martins Fontes, 1999.

FERRAJOLLI, Luigi. Derecho y Razón. Teoria del garantismo penal. $3^{\mathrm{a}}$ ed. Madrid: Trota, 1998.

FOUCAULT, Michel. Vigiar e Punir. Nascimento da prisão. $16^{\text {a }}$ ed. Petrópolis: Vozes, 1997a. . História da Loucura na Idade Clássica. 5a ed. São Paulo: Perspectiva, 1997b. . Microfísica do Poder. 15a ed. Rio de Janeiro: Graal, 2000.

. Em defesa da sociedade. Curso no Collège de France (1975-1976). São Paulo: Martins Fontes, 2002. . A Verdade e as Formas Jurídicas. $2^{\mathrm{a}}$ ed. Rio de Janeiro: Nau Editora, 2003a. . Ditos e Escritos, vol IV. Rio de Janeiro: Forense Universitária, 2003b.

Gallimard, 2004. . Naissance de la Biopolitique. Cours au Collège de France (1978-1979). Paris:

FRANCO, Alberto Silva. Crimes Hediondos. $4^{\mathrm{a}}$ edição. São Paulo: Editora Revista dos Tribunais, 2000.

FRY, Peter e CARRARA, Sérgio. "As vicissitudes do liberalismo no direito penal brasileiro. In: Revista Brasileira de Ciências Sociais, nº 2, vol. 1, outubro de 1986.

FUNDAÇÃO DE AMPARO AO TRABALHADOR PRESO - FUNAP/ SECRETARIA DE ADMINISTRAÇÃO PENITENCIÁRIA DE SÃO PAULO - SAP. Censo Penitenciário do Estado de São Paulo. São Paulo: 2002

FUNDAÇÃO SISTEMA ESTADUAL DE ANÁLISE DE DADOS - FSeade, Mulheres Negras, as mais punidas nos crimes de roubo. Relatório de Pesquisa. In: Boletim do IBCCRIM, n 125 , abril de 2003.

GALEANO, Eduardo e NEPUMUCENO, Eric. Palavras Andantes. Porto Alegre: L\&PM Editores, 1994.

GARLAND, David. Punishment and Modern Society. A Study in Social Theory. Chicago: Clarendon Press - Oxford, 1995.

. La Cultura del Control: Crimen y orden social en la sociedad contemporánea. Barcelona: Editorial Gedisa, 2005. 
GOES, Eda Maria. A recusa das grades: rebeliões nos presídios paulistas, 1982-1986. Dissertação de mestrado em História. Assis, UNESP, 1991.

GOFFMAN, Erwing. Manicômios, Prisões e Conventos. $5^{\mathrm{a}}$ Ed., São Paulo: Editora Perspectiva, 1996.

HULSMAN, Louk e CELIS, Jacqueline Bernat de. Penas Perdidas. O Sistema Penal em Questão. Niterói: Luam Editora, 1993.

INSTITUTO BRASILEIRO DE CIÊNCIAS CRIMINAIS - IBCCRIM/ INSTITUTO DE DEFESA DO DIREITO DE DEFESA - IDDD. Decisões judiciais nos crimes de roubo em São Paulo: a lei, o direito e a ideologia. São Paulo: IBCCRIM, 2005.

INSTITUTO LATINO AMERICANO DAS NAÇÕES UNIDAS PARA PREVENÇÃO DO CRIME E TRATAMENTO DO DELINQÜENTE - ILANUD. Sistema Penitenciário: Mudanças de Perfil dos anos 50 aos 90. São Paulo: Revista do ILANUD, nº 6, 1997.

JACKOBS, Günther. “Derecho Penal del enemigo y Derecho Penal del ciudadano”. In: Derecho Penal del Enemigo (Günther Jackobs e Manuel Cancio Meliá). Madrid: Civitas Ediciones, 2003.

KOERNER, Andrei. Judiciário e Cidadania na constituição da república brasileira. São Paulo: Editora Hucitec, 1998. . Panorama histórico do livramento condicional no Brasil. São Paulo: mimeo.

KOSELLECK, Reinhart. Futuro Pasado: para una semântica de los tiempos históricos. Barcelona: Ediciones Paidós, 1993.

LÈVI, Primo. É isto um homem? Rio de Janeiro: Editora Rocco, 1988.

LYRA, Roberto. Comentários ao Código de Processo Penal. Vol. IV. Rio de Janeiro: Edição Revista Forense, 1944.

MARTINS, Sérgio Mazina. "Reflexões sobre a desativação de um presídio”. In: Juízes para a Democracia, publicação oficial da Associação Juízes para a Democracia, $\mathrm{n}^{0} 24$, abril-junho de 2001.

" "Problemas dos sistemas penitenciários brasileiros em face das organizações criminosas”. In: Direito e Cidadania, n 20/21. Praia: maio-dez 2004.

MELOSSI, Dario e PAVARINI, Massimo. Cárcere e Fábrica. As origens do sistema penitenciário (séculos XVI - XIX). Rio de Janeiro: Editora Revan, 2006.

OLIVEIRA, Francisco de. "Privatização do público, destituição da fala e anulação da política: o totalitarismo neoliberal”. In: Os sentidos da democracia (org. Francisco de Oliveira e Maria Célia Paoli). 2a ed. Petrópolis: Editora Vozes, 2000.

PAIXÃO, Antonio Luiz. Recuperar ou punir: como o Estado trata o criminoso. São Paulo: Cortez, 1987.

PAOLI, Maria Célia. “O mundo do indistinto: sobre gestão, violência e política”. In: OLIVEIRA, Francisco e RIZEK, Cibele (ogs.). A política na era da indeterminação. São Paulo: Boitempo, [s.d.] (mimeo).

PIMENTEL, Manoel Pedro. Prisões Fechadas, Prisões Abertas. São Paulo: Cortez e Moraes, 1978. 
PINHEIRO, Paulo Sérgio e BRAUN, Eric (org). Democracia x Violência. Reflexões para a Constituinte. Rio de Janeiro: Editora Paz e Terra, 1986.

QUEIROZ, José J. As prisões, os jovens e o povo. São Paulo: Edições Paulinas, 1985.

RAMALHO, José Ricardo. O Mundo do Crime. A ordem pelo avesso. $3^{\text {a }}$ ed. São Paulo: Instituto Brasileiro de Ciências Criminais, 2002.

RANCIÈRE, Jacques. O Desentendimento. São Paulo: Editora 34, 1996.

RHODES, Lorna A. "A psicopatia e a cara do controle na supermax". In: Discursos Sediciosos, Crime, Direito e Sociedade, n 13, Rio de Janeiro: Editora Renavan, 2004.

RUSCHE, Georg; KIRCHHEIMER, Otto. Punição e estrutura social. Rio de Janeiro: Freitas Bastos Editora, 1999.

SALLA, Fernando. As prisões em São Paulo: 1822-1940. São Paulo: Annablume Editora Comunicação, Fundação de Amparo à Pesquisa do Estado de São Paulo - FAPESP, 1999.

. “Casa de Detenção de São Paulo. Passado e Presente”. In: Revista Brasileira de Ciências Criminas, São Paulo: Editora Revista dos Tribunais, n 32, out-dez de 2000. setembro de 2001.

"Rebeliões nas prisões brasileiras". In: Serviço Social e Sociedade. n 67,

SANTOS, Boaventura de Souza. "Reinventar a democracia: entre o pré-contratualismo e o pós-contratualismo” In: OLIVEIRA, Francisco de \& PAOLI, Maria Célia. Os sentidos da democracia: políticas do dissenso e hegemonia global. Petrópolis: Vozes, 2000.

SYKES, Gresham M. The Society of Captives. A study of Maximum Security Prision. $11^{\mathrm{a}}$ Printing. New Jersey: Princeton University Press, 1999.

TEIXEIRA, Alessandra e BORDINI, Eliana B. T., "Decisões Judiciais da Vara de Execuções Criminais: Punindo Sempre mais” In: São Paulo em Perspectiva, vol.18, n 1 , jan-mar de 2004.

TELLES, Vera da Silva. Pobreza e Cidadania. São Paulo: Editora 34, 2001.

- Trabalho, cidade e os elos perdidos da política. Texto apresentado no seminário "Francisco de Oliveira, a tarefa crítica”, USP, outubro de 2003.

"Transitando na linha de sombra, tecendo as tramas da cidade" In: OLIVEIRA, Francisco e RIZEK, Cibele (ogs.). A política na era da indeterminação. São Paulo: Boitempo, [s.d.] (mimeo)

THOMPSON, E.P., Costumes em Comum. Estudos sobre a cultura popular tradicional. São Paulo: Companhia das Letras, 2002.

TOPALOV, Christian. “A Invenção do desemprego”. DADOS, vol. 33, n 3, 1999.

VIVANCO, José Miguel e MESQUITA NETO, Paulo. Será que nos enganamos? Folha de S. Paulo, Tendências e Debates, 19 de fevereiro de 2006.

WACQUANT, Loïc. Punir os pobres: a nova gestão da miséria nos Estados Unidos. Rio de Janeiro: Freitas Bastos Editora, 2000.

. As prisões da miséria. Rio de Janeiro: Jorge Zahar Ed., 2001.

WEBER, Max. A Ética protestante e o espírito do capitalismo. $4^{\mathrm{a}}$ ed. Lisboa: Editorial Presença, 1996. 
ZALUAR, Alba. "Violência e Crime”. O que ler na ciência social brasileira (1970-1995) Antropologia - vol. I. São Paulo: Anpocs, Editora Sumaré, 1999.

\section{FONTES}

Comissão Especial de Inquérito (CEI) sobre Organização Policial do Estado de São Paulo da Assembléia Legislativa do Estado de São Paulo, instaurada em 15 de maio de 1984. Presidente: Deputado Antonio Resk.

Comissão Parlamentar de Inquérito (CPI) sobre o Sistema Prisional de São Paulo. Assembléia Legislativa, CPI instaurada em 23 de maio de 2001. Presidente: Deputada Rosemary Corrêa.

Diário Congresso Nacional (DCN) de 28 de setembro de 1989 e 29 de junho de 1990.

Memorando de Entendimento (MDE) Relativo ao Controle de Entorpecentes e Repressão Legal entre a República Federativa do Brasil e os Estados Unidos da América, ano fiscal de 2001. Ministério da Justiça, Secretaria Nacional Anti-Drogas - SENAD.

Relatório da Comissão Parlamentar de Inquérito (CPI) para apurar a situação penitenciária do país. Diário do Congresso Nacional (DCN), Suplemento ao $n^{0} 61$ de 04 de junho de 1976.

Relatório Final da Comissão Parlamentar de Inquérito (CPI) para apuração dos fatos ocorridos no Pavilhão 9, Casa de Detenção de São Paulo no dia 02/10/1992. Diário Oficial do Estado, 02.12.1992.

\section{JORNAIS E REVISTAS}

Informativo InterAÇÃO Magistratura, Escola Paulista da Magistratura de São Paulo, $\mathrm{n}^{\circ}$ 74, maio-junho de 2006.

Jornal Folha de S. Paulo, exemplares diversos.

Jornal O Estado de S. Paulo, exemplares diversos.

Revista Caros Amigos, Edição Extra, PCC, maio de 2006.

Revista Carta Capital, nº 185, de 17 de abril de 2002.

Revista Consultor Jurídico, 22 de fevereiro de 2006. 